REV. 0

\title{
BASELINE RISK AsSESSMENT OF GROUND WATER ConTAMINATION AT THE URANIUM MILL TAILINGS Site Near Green River, Utah
}

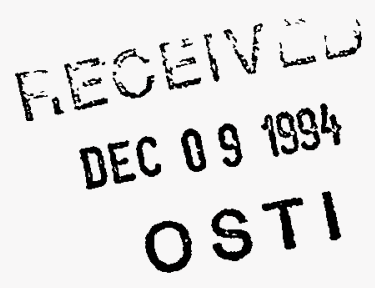

\section{September 1994}

\section{DISCLAIMER}

This report was prepared as an account of work sponsored by an agency of the United States Government. Neither the United States Government nor any agency thereof, nor any of their employees, makes any warranty, express or implied, or assumes any legal liability or responsibility for the accuracy, completeness, or usefulness of any information, apparatus, product, or process disclosed, or represents that its use would not infringe privately owned rights. Reference herein to any specific commercial product, process, or service by trade name, trademark, manufacturer, or otherwise does not necessarily constitute or imply its endorsement, recommendation, or favoring by the United States Government or any agency thereof. The views and opinions of authors expressed herein do not necessarily state or reflect those of the United States Government or any agency thereof. 


\section{DISCLAIMER}

Portions of this document may be illegible in electronic image products. Images are produced from the best available original document. 


\section{INTENDED FOR PUBLIC RELEASE}

This report has been reproduced from the best available copy. Available in paper copy and microfiche.

Number of pages in this report: 196

DOE and DOE contractors can obtain copies of this report from:

Office of Scientific and Technical Information

P.O. Box 62

Oak Ridge, TN 37831

(615) 576-8401

This report is publicly available from:

National Technical Information Service

Department of Commerce

5285 Port Royal Road

Springfield, VA 22161

(703) $487-4650$ 
REV. 0

BASELINE RISK ASSESSMENT OF GROUND WATER CONTAMINATION AT THE URANIUM MILL TAILINGS SITE NEAR GREEN RIVER, UTAH

September 1994

Prepared for

U.S. Department of Energy UMTRA Project Office

Albuquerque, New Mexico

Prepared by

Jacobs Engineering Group Inc.

Albuquerque, New Mexico 


\section{CITIZENS' SUMMARY}

This Baseline Risk Assessment of Ground Water Contamination at the Uranium Mill Tailings Site near Green River, Utah, evaluates potential impacts to public health and the environment resulting from ground water contamination at the former uranium mill processing site. The tailings and other contaminated material at this site were placed in a disposal cell on the site in 1989 by the U.S. Department of Energy's Uranium Mill Tailings Remedial Action (UMTRA) Project. Currently, the UMTRA Project is evaluating ground water contamination. This risk assessment is the first document specific to this site for the Ground Water Project.

Currently, no domestic or drinking-water wells exist in the contaminated ground water. This includes two distinct ground water units: the contaminated ground water in the Brown's Wash alluvium (above which the former uranium mill tailings were located) and the contaminated ground water in the Upper Cedar Mountain aquifer. Because no one is drinking the affected ground water, there are currently no health risks directly associated with the contaminated ground water. However, there is a potential for domestic animals and wildlife to be exposed to contaminants in the alluvial ground water, which seeps to the surface and forms pools in the channel of Brown's Wash downstream of the site. For these reasons, this risk assessment evaluates potential exposure to contaminated surface water as well as potential future use of contaminated ground water.

This risk assessment follows the basic approach prescribed by the U.S. Environmental Protection Agency. The first step is to evaluate ground water data collected from monitor wells at the site. Evaluation of these data showed that the contaminants related to uranium processing and of interest to this risk evaluation in the Upper Cedar Mountain aquifer are arsenic, manganese, molybdenum, nitrate, selenium, sodium, sulfate, uranium, and vanadium. The complete list of contaminants associated with the Brown's Wash alluvium ground water could not be determined due to the lack of the background ground water quality data. However, the levels of uranium, nitrate, and sulfate are evaluated qualitatively (by comparison to health-based criteria) since these chemicals are clearly associated with uranium processing and at observed concentrations exhibit the greatest toxicity.

The next step in the risk assessment is to estimate how much of these contaminants people would be exposed to if a drinking water well were installed in the contaminated ground water. Since contaminant concentrations vary each time a well is sampled and since people vary in how much they weigh and drink, this risk assessment used probability distributions to determine the amounts of contaminants that people would likely ingest if they had a well in the Upper Cedar Mountain aquifer at the site. The probability distributions describe how likely it is for something to happen. For example, based on population surveys, probability distributions can describe what percentage of people drink a half-gallon of water each day and what percentage drink only one cup of water each day.

These estimated amounts of contaminants that people might take in by consuming tap water are then compared to the toxic effects these contaminant levels might cause. The 
most significant health hazard in the ground water at the Green River former mill site is nitrate. The levels of nitrate in the Brown's Wash alluvium and Upper Cedar Mountain aquifer ground water near the site exceed levels that have been reported elsewhere to be lethal when ingested by infants. For this reason, the Department of Energy is working with the state of Utah to restrict access to contaminated ground water until the site can be further evaluated.

Other contaminants that occur at levels associated with adverse health effects in the Upper Cedar Mountain aquifer ground water are sulfate, manganese, selenium, and sodium. The sulfate concentrations in the alluvial and Upper Cedar Mountain aquifer ground water near the site would cause severe diarrhea and dehydration if ground water were ingested, particularly by infants. The nitrate and sulfate levels would also be unacceptable for domestic animals and wildlife. Chronic ingestion of this water could result in mild toxicity to humans from exposures to manganese, sodium, and selenium. The amounts of manganese potentially ingested over a long period of time would be expected to adversely affect the nervous system, sodium levels would contribute to the development of hypertension, and selenium levels could cause nail and hair brittleness or loss.

Ingestion of drinking water with uranium and arsenic concentrations at the site may increase the risk of cancer. The additional cancer risk from ingesting uraniumcontaminated ground water for a lifetime would be an average 8 in 10,000 for the Brown's Wash alluvium and 7 in 10,000 for the Upper Cedar Mountain aquifer. The additional lifetime cancer risk from exposure to arsenic in the Upper Cedar Mountain ground water would average 9 in 10,000.

This risk assessment also evaluated potential effects on livestock if the ground water were used to water cattle or sheep, and if cattle or sheep drank water from pools of contaminated surface water while grazing in Brown's Wash. These animals are sensitive to nitrate. The nitrate concentrations near the mill site are high enough to cause these animals to die if this water were a major source of drinking water. The elevated selenium concentrations could result in chronic selenosis in livestock that may drink contaminated water. Sulfate levels are high enough to cause diarrhea if livestock drank the contaminated ground water.

Surface water from Brown's Wash and alluvial ground water contaminated with nitrate, selenium, and uranium would pose a potential risk to the biological environment. Nitrate levels could be toxic to wildlife. The levels of selenium in the surface water could be toxic to aquatic life. It is likely that selenium, cadmium, and uranium are entering the terrestrial environment from the contaminated water and sediments, but the impacts are not known at this time. However, due to high water alkalinity, the uranium levels are not likely to be toxic to aquatic life.

The mill tailings disposal cell at the Green River site is currently being monitored. The Green River site will be further evaluated under the UMTRA Ground Water Project. This will include further evaluation of the Brown's Wash surface water, the alluvium ground water and its movement, and the Upper Cedar Mountain aquifer ground water. More advanced procedures to further evaluate potential impacts to the ecosystem will be 
considered. Based on these new results, this risk assessment, and other ground water documents, an approach will be developed to address water contamination. In the interim, control of access to contaminated ground water is being pursued at the Green River site. 


\section{TABLE OF CONTENTS}

\section{Section}

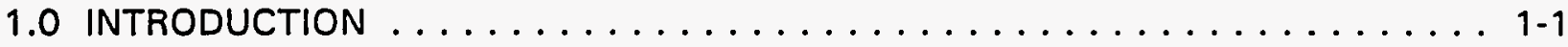

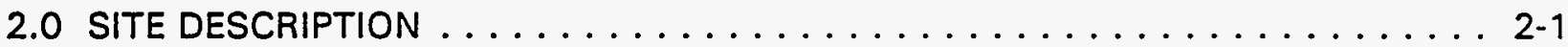

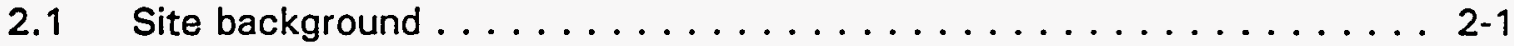

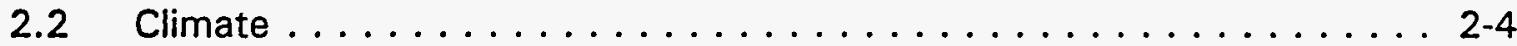

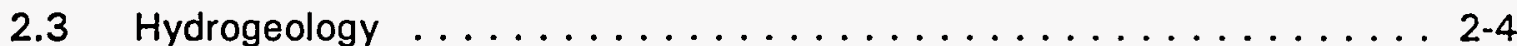

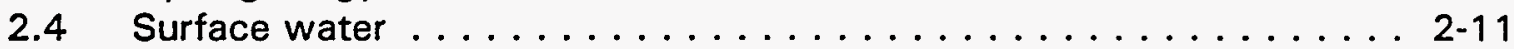

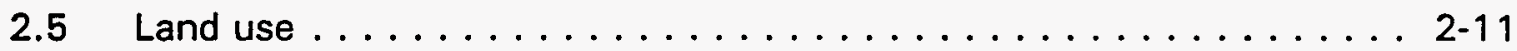

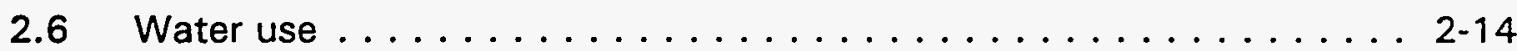

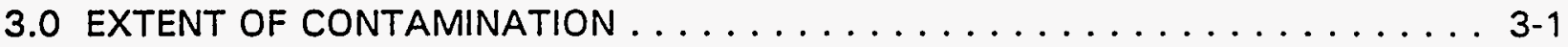

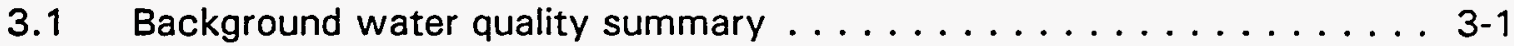

3.1.1 Alluvial system ..................... 3-1

3.1 .2 Upper Cedar Mountain aquifer .............. 3-5

3.2 Magnitude of site-related contamination . . . . . . . . . . . . . 3-6

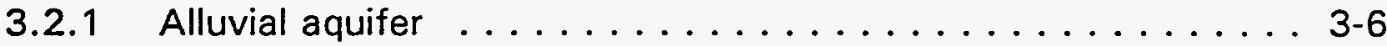

3.2.2 Upper Cedar Mountain aquifer ............... 3-11

3.3 Contaminants of potential concern . . . . . . . . . . . . 3-15

3.4 Contaminant fate and transport . . . . . . . . . . . . 3-17

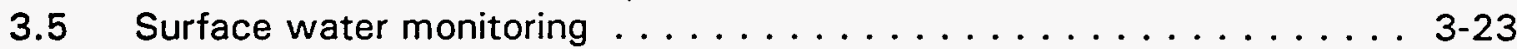

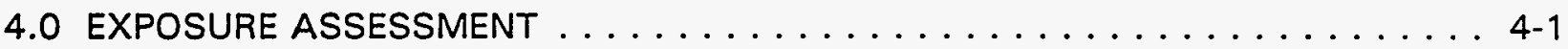

4.1 Potentially exposed population ................ 4 . 1

4.2 Exposure pathways ....................... 4.2

4.2.1 Drinking water ingestion ................. 4-2

4.2.2. Dermal absorption ...................... 4-2

4.2.3 Ingestion of ground water-irrigated produce .......... 4-6

4.2.4 Ingestion of meat or milk from livestock ingesting ground

water ......................... 4-6

4.3 Exposure concentrations . . . . . . . . . . . . . . . . 4-6

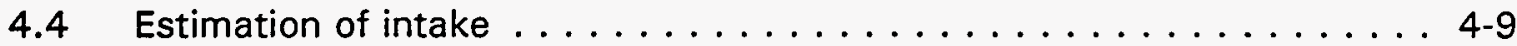

4.5 Exposure assessment uncertainties ................ 4-34

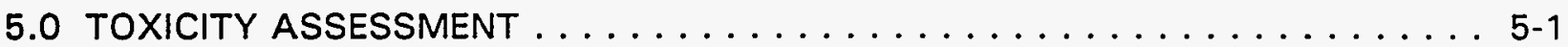

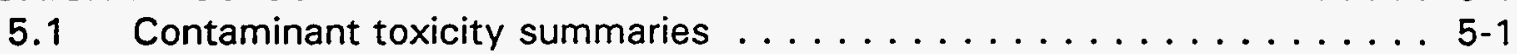

5.1 .1 Arsenic . . . . . . . . . . . . . . . . 5-1

5.1 .2 Manganese ....................... $5-4$

5.1 .3 Molybdenum ....................... 5-9

5.1 .4 Nitrate ......................... 5-11

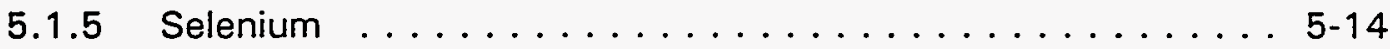

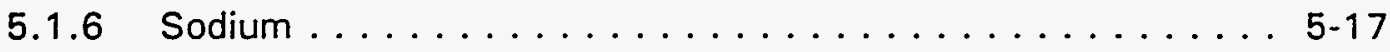

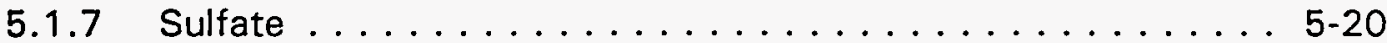




\section{TABLE OF CONTENTS (Concluded)}

$\underline{\text { Section }}$

5.1 .8 Uranium . . . . . . . . . . . . . . . . 5-23

5.1 .9 Vanadium ...................... $5-28$

5.2 Contaminant interactions . . . . . . . . . . . . . 5-30

5.3 Contaminant risk factors . . . . . . . . . . . . . . . . . 5-33

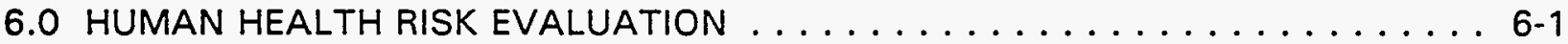

6.1 Potential noncarcinogenic health effects . . . . . . . . . . 6-1

6.1.1 Brown's Wash alluvium ground water potential use . . . . . . . 6-1

6.1.2 Upper Cedar Mountain aquifer ground water potential use . . . 6- 6-1

6.2 Potential carcinogenic health effects . . . . . . . . . . . . . 6-9

6.3 Limitations of the human health risk evaluation . . . . . . . . . . 6-18

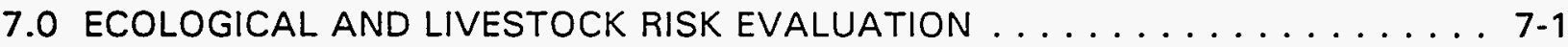

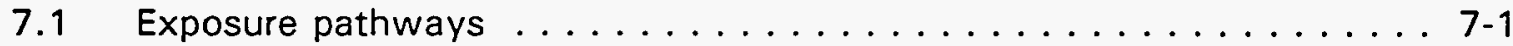

7.2 Ecological receptors .................... $7-2$

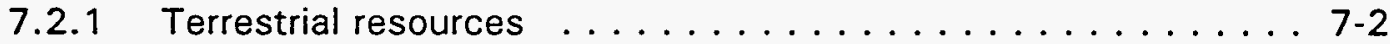

7.2 .2 Aquatic resources .................. 7-3

7.3 Contaminants of potential ecological concern ............ $7-3$

7.3.1 Surface water and sediment sampling sites . . . . . . . . 7-5

7.3.2 Source of sediment and surface water contamination . . . . . 7-6

7.3.3 Contaminants of potential concern . . . . . . . . . . . 7-7

7.4 Potential impacts to terrestrial and aquatic resources . . . . . . . . 7-10

7.4.1 Ecological risk of surface contamination . . . . . . . . . 7-10

7.4.2 Ecological risk associated with plant root transport of

contaminants ................. 7-16

7.5 Potential impacts to livestock ............... 7 .17

7.6 Limitations of the ecological risk assessment $\ldots \ldots \ldots \ldots \ldots \ldots$ 7-19

7.7 Summary ......................... 7-20

8.0 INTERPRETATION AND RECOMMENDATIONS .............. 8 .1

8.1 Risk summary . . . . . . . . . . . . . . . . .

8.2 Limitations of this risk assessment $\ldots \ldots \ldots \ldots \ldots \ldots \ldots \ldots . \ldots . \ldots . \ldots$

8.3 Ground water criteria . . . . . . . . . . . . . . . . 8 8-3

8.4 Risk mitigation measures ..................... 8.5

8.5 Recommendations ...................... 8 .6

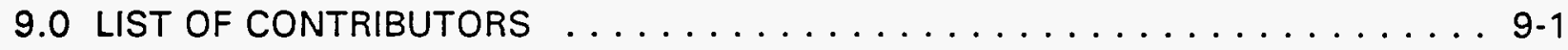

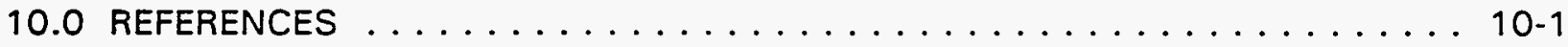




\section{LIST OF FIGURES}

Figure

2.1 Green River site location map, Green River, Utah, site . . . . . . . . . . . . 2-2

2.2 Aerial view of Green River, Utah, site during operating period . . . . . . . . . 2-3

2.3 Hydrostratigraphic cross section A-A', Green River, Utah, site . . . . . . . . . 2-5

2.4 Potentiometric surface, processing site area, top hydrostratigraphic unit, January 1988, Green River, Utah, site . . . . . . . . . . . . . . . . 2-7

2.5 Potentiometric surface, disposal site area, middle hydrostratigraphic sandstone, October 1993, Green River, Utah, site . . . . . . . . . . . . . . 2-9

2.6 Local physiographic setting, Green River, Utah, site . . . . . . . . . . 2-12

2.7 Land use in the Green River, Utah, site vicinity . . . . . . . . . . . . . 2-13

2.8 Locations of registered ground water wells near Green River, Utah, site . . . 2-15

3.1 Ground water and surface water sampling locations, Green River, Utah,

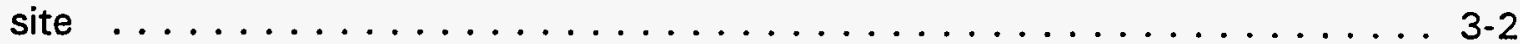

3.2 Uranium plume in the alluvial aquifer, Green River, Utah, site . . . . . . . . . 3-9

3.3 Nitrate plume in the alluvial aquifer, Green River, Utah, site . . . . . . . . 3-10

4.1 Conceptual model, Green River, Utah, site . . . . . . . . . . . . . . 4-3

4.2 Probability distribution of arsenic concentrations for the Upper Cedar Mountain aquifer, Green River, Utah, site . . . . . . . . . . . . . . 4-10

4.3 Probability distribution of manganese concentrations for the Upper Cedar Mountain aquifer, Green River, Utah, site . . . . . . . . . . . . . 4-11

4.4 Probability distribution of molybdenum concentrations for the Upper Cedar Mountain aquifer, Green River, Utah, site . . . . . . . . . . . . . . 4-12

4.5 Probability distribution of nitrate concentrations for the Upper Cedar Mountain aquifer, Green River, Utah, site . . . . . . . . . . . . . . 4-13

4.6 Probability distribution of selenium concentrations for the Upper Cedar Mountain aquifer, Green River, Utah, site . . . . . . . . . . . . . . . . 4-14

4.7 Probability distribution of sodium concentrations for the Upper Cedar Mountain aquifer, Green River, Utah, site . . . . . . . . . . . . . 4 4-15

4.8 Probability distribution of sulfate concentrations for the Upper Cedar Mountain aquifer, Green River, Utah, site . . . . . . . . . . . . . 4-16

4.9 Probability distribution of uranium concentrations for the Upper Cedar Mountain aquifer, Green River, Utah, site . . . . . . . . . . . . . 4-17

4.10 Probability distribution of vanadium concentrations for the Upper Cedar Mountain aquifer, Green River, Utah, site . . . . . . . . . . . . 4-18

4.11 Probability distributions for tap water ingestion rates by age group . . . . . 4-20

4.12 Body weight probability distributions by age group . . . . . . . . . 4-22

4.13 Probability distribution of arsenic intakes, Green River, Utah, site . . . . . . . 4-23

4.14 Probability distribution of manganese intakes, Green River, Utah, site . . . . . 4-24

4.15 Probability distribution of molybdenum intakes, Green River, Utah, site . . . . 4-25

4.16 Probability distribution of nitrate intakes, Green River, Utah, site . . . . . . 4-26

4.17 Probability distribution of selenium intakes, Green River, Utah, site . . . . . 4 4-27

4.18 Probability distribution of sodium intakes, Green River, Utah, site . . . . . . . 4-28

4.19 Probability distribution of sulfate intakes, Green River, Utah, site . . . . . . . 4-29 


\section{LIST OF FIGURES (Continued)}

Figure

Page

4.20 Probability distribution of uranium intakes, Green River, Utah, site . . . . . 4-30

4.21 Probability distribution of vanadium intakes, Green River, Utah, site . . . . . 4-31

4.22 Probability distribution of arsenic intakes averaged over a lifetime,

Green River, Utah, site . . . . . . . . . . . . . . . . . . . . . 4-32

4.23 Probability distribution of lifetime uranium intakes, Green River,

Utah, site ............................ 4-33

5.1 Arsenic toxicity ranges . . . . . . . . . . . . . . . . . 5-6

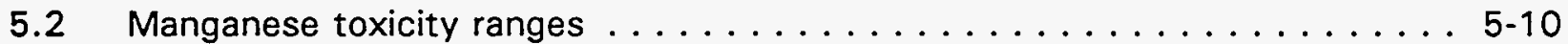

5.3 Molybdenum toxicity ranges . . . . . . . . . . . . . . . . . . . 5-12

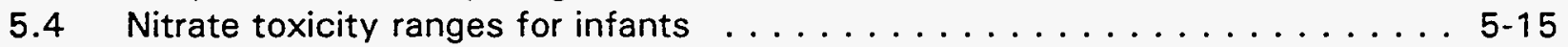

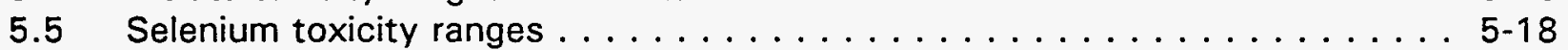

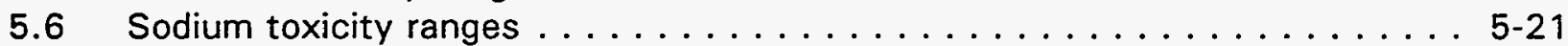

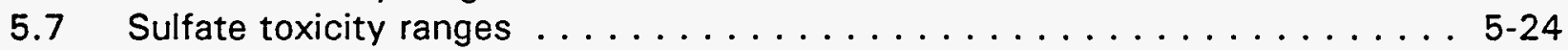

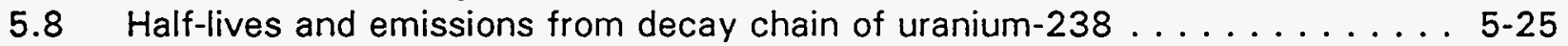

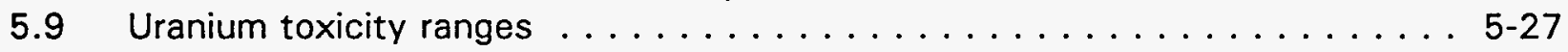

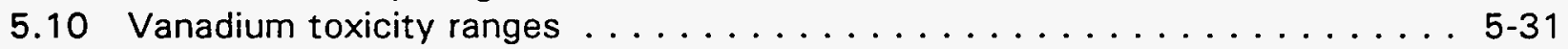

6.1 Health effects of potential nitrate exposure ranges for infants ingesting

Upper Cedar Mountain aquifer ground water, Green River, Utah, site . . . . . . 6-3

6.2 Health effects of potential sulfate exposure ranges for infants ingesting

Upper Cedar Mountain aquifer ground water, Green River, Utah, site . . . . . . 6-5

6.3 Health effects of potential sodium exposure ranges for children ingesting

Upper Cedar Mountain aquifer ground water, Green River, Utah, site . . . . . . . 6-6

6.4 Health effects of potential manganese exposure ranges for children

ingesting Upper Cedar Mountain aquifer ground water, Green River,

Utah, site . . . . . . . . . . . . . . . . . . . . . . . . . 6-7

6.5 Health effects of potential selenium exposure ranges for children ingesting Upper Cedar Mountain aquifer ground water, Green River,

Utah, site .............................6-8

6.6 Health effects of potential arsenic exposure ranges for children ingesting Upper Cedar Mountain aquifer ground water, Green River,

Utah, site . . . . . . . . . . . . . . . . . . . . . . . 6-10

6.7 Health effects of potential molybdenum exposure ranges for children

ingesting Upper Cedar Mountain aquifer ground water, Green River,

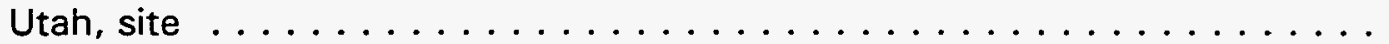

6.8 Health effects of potential uranium exposure ranges for children

ingesting Upper Cedar Mountain aquifer ground water, Green River,

Utah, site . . . . . . . . . . . . . . . . . . . . . 6-12

6.9 Health effects of potential vanadium exposure ranges for children

ingesting Upper Cedar Mountain aquifer ground water, Green River,

Utah, site ............................ 6-13 


\section{LIST OF FIGURES (Continued)}

Figure

Page

6.10 Increased lifetime cancer risk associated with potential arsenic exposure ranges for adults ingesting contaminated Upper Cedar Mountain aquifer ground water, Green River, Utah, site . . . . . . . . . . . 6 6-15

6.11 Increased lifetime cancer risk associated with potential uranium-234/238 exposure ranges for the contaminated Upper Cedar Mountain aquifer ground water, Green River, Utah, site . . . . . . . . . . . . . . 6-16

7.1 Surface water, soil, and sediment sampling locations along Brown's Wash . . 7-4 


\section{LIST OF TABLES}

2.1 Ground water elevations, Green River, Utah, site . . . . . . . . . . . 2-10

2.2 Registered water wells near the Green River, Utah, site . . . . . . . . . . . 2-16

3.1 Monitor well and surface water sampling information for the Green River, Utah, site . . . . . . . . . . . . . . . . . . . . . 3-3

3.2 Statistical summary of the Brown's Wash alluvium on-site ground water data, 1986 to 1988 , filtered samples, Green River, Utah, site . . . . . . . . . . 3-7

3.3 Statistical summary of ground water quality data for the Upper Cedar Mountain aquifer, Green River, Utah, site . . . . . . . . . . . . 3-13

3.4 Contaminants of potential concern for the Upper Cedar Mountain aquifer . . . 3-16

3.5 Aqueous species of contaminants of potential concern in the Upper Cedar Mountain aquifer at Green River, Utah ................... 3-18

3.6 Statistical summary of surface water quality data for the Green River, Green River, Utah, site . . . . . . . . . . . . . . . . . 3-24

4.1 Exposure dose calculations and equation definitions for the Upper Cedar Mountain aquifer ground water usage in future hypothetical adult scenarios, Green River UMTRA Project site, Green River, Utah . . . . . . . . . . . . . . . 4-4

4.2 Exposure dose calculations and equation definitions for the Upper Cedar Mountain aquifer ground water-irrigated produce ingestion in future hypothetical adult scenarios, Green River UMTRA Project site, Green River,

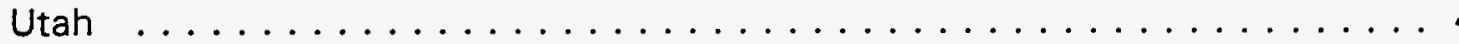

5.1 Toxicity values: potential carcinogenic effects . . . . . . . . . . . 5-5

5.2 Toxicity values: potential noncarcinogenic effects . . . . . . . . . 5-34

6.1 Potential adverse health effects from ingestion of nitrate, sulfate, and uranium in the Brown's Wash alluvium ground water, Green River, Utah, site . 6-2

6.2 Carcinogenic risk for the Brown's Wash alluvium ground water ingestion pathway at the Green River, Utah, site .................. 6-14

6.3 Carcinogenic risk for the Upper Cedar Mountain aquifer ground water ingestion pathway at the Green River, Utah, site . . . . . . . . . . . . . . 6-17

7.1 Surface water sampling sites along Brown's Wash at the Green River, Utah, site ................................

7.2 Constituents detected in the contaminated portions of the Upper Cedar Mountain aquifer, Brown's Wash alluvial ground water, and surface water pools ................................ 7-8

7.3 Concentrations of contaminants of potential concern in the surface and alluvial water of Brown's Wash at the Green River, Utah, UMTRA Project site (filtered water samples, except as noted, 1988 to 1993) . . . . . . . . 7-11

7.4 Concentrations of contaminants of potential concern in sediment samples collected along Brown's Wash, September 1993, Green River, Utah, site . . . 7-12

7.5 Comparison of estimated plant concentrations of contaminants of potential concern to phytotoxic concentrations, Green River, Utah, site . . . . . . . 7-18 


\section{LIST OF TABLES (Concluded)}

$\underline{\text { Table }}$

Page

8.1 Concentration limits of constituents present in the Upper Cedar Mountain

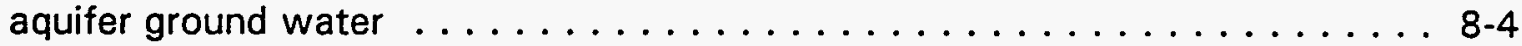




\section{LIST OF ACRONYMS AND ABBREVIATIONS}

\begin{tabular}{|c|c|}
\hline Acronym & Definition \\
\hline ac & acre \\
\hline $\mathrm{ACL}$ & alternate concentration limit \\
\hline $\begin{array}{l}\text { ATSDR } \\
{ }^{\circ} \mathrm{C}\end{array}$ & $\begin{array}{l}\text { Agency for Toxic Substances and Disease Registry } \\
\text { degrees Celsius }\end{array}$ \\
\hline $\mathrm{cm}$ & centimeter \\
\hline $\mathrm{cm}^{2}$ & square centimeter \\
\hline $\mathrm{cm}^{3}$ & cubic centimeter \\
\hline D\&RGW & Denver and Rio Grande Western \\
\hline DHHS & Department of Health and Human Services \\
\hline DL & detection limit \\
\hline DO & dissolved oxygen \\
\hline DOE & U.S. Department of Energy \\
\hline DW & dry weight \\
\hline EPA & U.S. Environmental Protection Agency \\
\hline${ }^{\circ} \mathrm{F}$ & degrees Fahrenheit \\
\hline & foot \\
\hline $\mathrm{ft}^{3}$ & cubic foot \\
\hline $\mathrm{ft}^{3} / \mathrm{s}$ & cubic feet per second \\
\hline $\begin{array}{l}\text { FWOC } \\
\text { ha }\end{array}$ & $\begin{array}{l}\text { Federal Water Quality Criteria } \\
\text { hectare }\end{array}$ \\
\hline HEAST & Health Effects Assessment Summary Tables \\
\hline IRIS & Integrated Risk Information System \\
\hline $\mathrm{km}$ & kilometer \\
\hline $\mathrm{km}^{2}$ & square kilometer \\
\hline L & liter \\
\hline $\mathrm{L} / \mathrm{kg}$ & liters per kilogram \\
\hline LOAEL & lowest-observed-adverse-effect level \\
\hline$L / S$ & liters per second \\
\hline$\mu \mathrm{g} / \mathrm{kg}$ & micrograms per kilogram \\
\hline$m$ & meter \\
\hline$m^{3}$ & cubic meter \\
\hline $\mathrm{MCL}$ & maximum concentration limit \\
\hline $\mathrm{mg} / \mathrm{kg}$-day & milligrams per kilogram per day \\
\hline $\mathrm{mg} / \mathrm{L}$ & milligrams per liter \\
\hline $\mathrm{mi}$ & mile \\
\hline $\mathrm{mi}^{2}$ & square mile \\
\hline MSL & mean sea level \\
\hline $\mathrm{mV}$ & millivolt \\
\hline NCP & National Contingency Plan \\
\hline $\mathrm{ng} / \mathrm{mL}$ & nanograms per milliliter \\
\hline NOAEL & no-observed-adverse-effect level \\
\hline NRC & U.S. Nuclear Regulatory Commission \\
\hline $\mathrm{pCi} / \mathrm{L}$ & picocuries per liter \\
\hline PEIS & programmatic environmental impact statement \\
\hline
\end{tabular}




\section{LIST OF ACRONYMS AND ABBREVIATIONS (Continued)}

Acronym Definition

RAP remedial action plan

RCRA Resource Conservation and Recovery Act

redox reduction/oxidation

RfD reference dose

SF slope factor

SOP standard operating procedure

TDS total dissolved solids

UMTRA Uranium Mill Tailings Remedial Action

UMTRCA Uranium Mill Tailings Radiation Control Act

USGS U.S. Geological Survey

WHO World Health Organization 


\subsection{INTRODUCTION}

The purpose of this baseline risk assessment is to determine whether ground water contamination at the Green River, Utah, uranium mill tailings site has the potential to adversely affect public health or the environment. The Green River site is one of 24 abandoned uranium mill tailings sites undergoing remediation in accordance with the requirements of the Uranium Mill Tailings Radiation Control Act (UMTRCA) of 1978 (42 USC $\$ 7901$ et seq.) under the oversight of the U.S. Department of Energy (DOE) Uranium Mill Tailings Remedial Action (UMTRA) Project.

Under the UMTRA Surface Project, the DOE stabilized the tailings in a disposal cell to minimize radon and other radiation emissions and further contamination of ground water. Remedial action at the Green River site was completed in 1989 with stabilization of the tailings and other contaminated materials and soils at the former uranium mill site.

Under the UMTRA Ground Water Project, ground water contamination at the sites will be evaluated to determine whether remedial action is necessary; these actions would then be implemented. The DOE was authorized to perform ground water restoration in 1988 amendments to the UMTRCA.

The evaluation strategy and remediation methodology for contaminated ground water at UMTRA Project sites are described in the draft Programmatic Environmental Impact Statement for the Uranium Mill Tailings Remedial Action Ground Water Project (DOE, 1994a). This baseline risk assessment is one of the site-specific documents prepared to evaluate potential health and environmental risks and provide information to help determine what remedial action is necessary. This risk assessment, a site observational work plan, and a site-specific environmental assessment will be prepared following the programmatic environmental impact statement (PEIS) to evaluate and select a ground water compliance strategy for the Green River site.

This risk assessment is a baseline assessment in the sense that it describes preremediation ground water conditions at the site, with ground water contamination only partially characterized. Nonetheless, this document evaluates the potential for imminent public health or environmental risks that may need attention before the site is fully characterized.

The evaluation is based on available ground water data from the most contaminated wells at the processing site, and only major exposure pathways have been thoroughly examined. If future data collection, decisions, or actions at this site cause conditions to change, other pathways will be evaluated in more detail.

This risk assessment follows the basic framework outlined by the U.S. Environmental Protection Agency (EPA) (1989a) for evaluating hazardous waste sites to assess potential health and environmental impacts. The risk assessment process consists of the following steps: 
- Data evaluation.

- Combining existing data from various site investigations. This includes all relevant data, including state and military.

- Comparing sample results with background water quality and tailings source data.

- Selecting chemical data for use in the risk assessment.

- Exposure assessment.

- Characterizing exposure settings.

- Identifying exposure pathways.

- Quantifying exposure.

- Toxicity assessment.

- Identifying toxicity values.

- Evaluating noncarcinogenic effects.

- Evaluating carcinogenic effects from radionuclides and chemical carcinogens.

- Public health risk characterization.

- Comparing toxicity ranges to predicted exposure ranges.

- Combining risks across exposure pathways and multiple contaminants.

- Characterizing uncertainties.

- Environmental risk.

- Characterizing potential biota exposure pathways.

- Identifying potential ecological receptors.

- Evaluating environmental risk qualitatively.

This framework is incorporated in the methodology used to evaluate current human health risk at UMTRA Project sites and to estimate risks from potential future use of contaminated ground water or surface water near the former uranium processing site. A report describing this methodology is in preparation. 


\subsection{SITE DESCRIPTION}

The Green River site is in the east-central portion of Utah, in Grand County. The site is approximately 1 mile (mi) (1.6 kilometers [km]) southeast of the town of Green River, about $50 \mathrm{mi}(80 \mathrm{~km})$ northwest of Moab, Utah, and about $70 \mathrm{mi}(100 \mathrm{~km})$ west of the Utah-Colorado state line (Figure 2.1).

\subsection{SITE BACKGROUND}

The former uranium mill at the Green River site was constructed in 1957 and operated from March 1958 to January 1961 by the Union Carbide Corporation. Later, Union Carbide leased the site to Celesco, a company under contract with the U.S. Department of Defense, which used the mill buildings for missile testing and assembly. The Union Carbide Corporation owned the uranium mill site until the state of Utah acquired ownership in 1988. Figure 2.2 shows the Green River uranium processing site during its operating period.

The plant was operated for upgrading uranium ore from the Temple Mountain Mine area located approximately $60 \mathrm{mi}(100 \mathrm{~km})$ southwest of the site. During its 3 years of operation, the mill processed 183,000 tons $(167,000$ tonnes) of ore with an average grade of 0.29 percent uranium oxide (FBDU, 1981). The upgraded ore concentrate was shipped by rail to Rifle, Colorado, for further processing. The former Green River plant generated an estimated 137,000 tons (125,000 tonnes) of tailings, which covered approximately 9 acres (ac) (4 hectares [ha]) to an average depth of 7 feet (ft) (2 meters [m]).

Ore sent to the Green River plant consisted of sandstone loosely cemented with clay and asphaltic material, and part of the uranium was associated with carbonaceous minerals (Merritt, 1971). The ore was crushed and ground; the carbonaceous minerals were then separated by screening and flotation. The carbonaceous concentrate was stockpiled for later treatment.

The remaining feed slurry was separated into sand and slime fractions. The sand fraction was then leached with sulfuric acid at a $\mathrm{pH}$ of 0.5 for approximately 4 hours and washed in a six-stage classifier. The spent sands were discarded as tailings. This leached slurry was then mixed with a portion of the original slime fraction in an acid kill tank, and acidity was reduced to a $\mathrm{pH}$ of between 5 and 6 . Final neutralization of this slurry with ammonia precipitated uranium and other associated constituents and minerals. This slurry and the remaining original slimes were then dewatered and dried for shipment to the Rifle, Colorado, plant.

Between 1988 and 1989 , mill tailings and associated contaminated soils and materials were stabilized on the site in a permanent disposal cell. The disposal cell is on an elevated terrace approximately $600 \mathrm{ft}(180 \mathrm{~m})$ south of Brown's Wash (DOE, 1994b) and approximately $500 \mathrm{ft}(150 \mathrm{~m})$ south-southeast of the processing site area. The disposal cell base is approximately $35 \mathrm{ft}(10 \mathrm{~m})$ below 

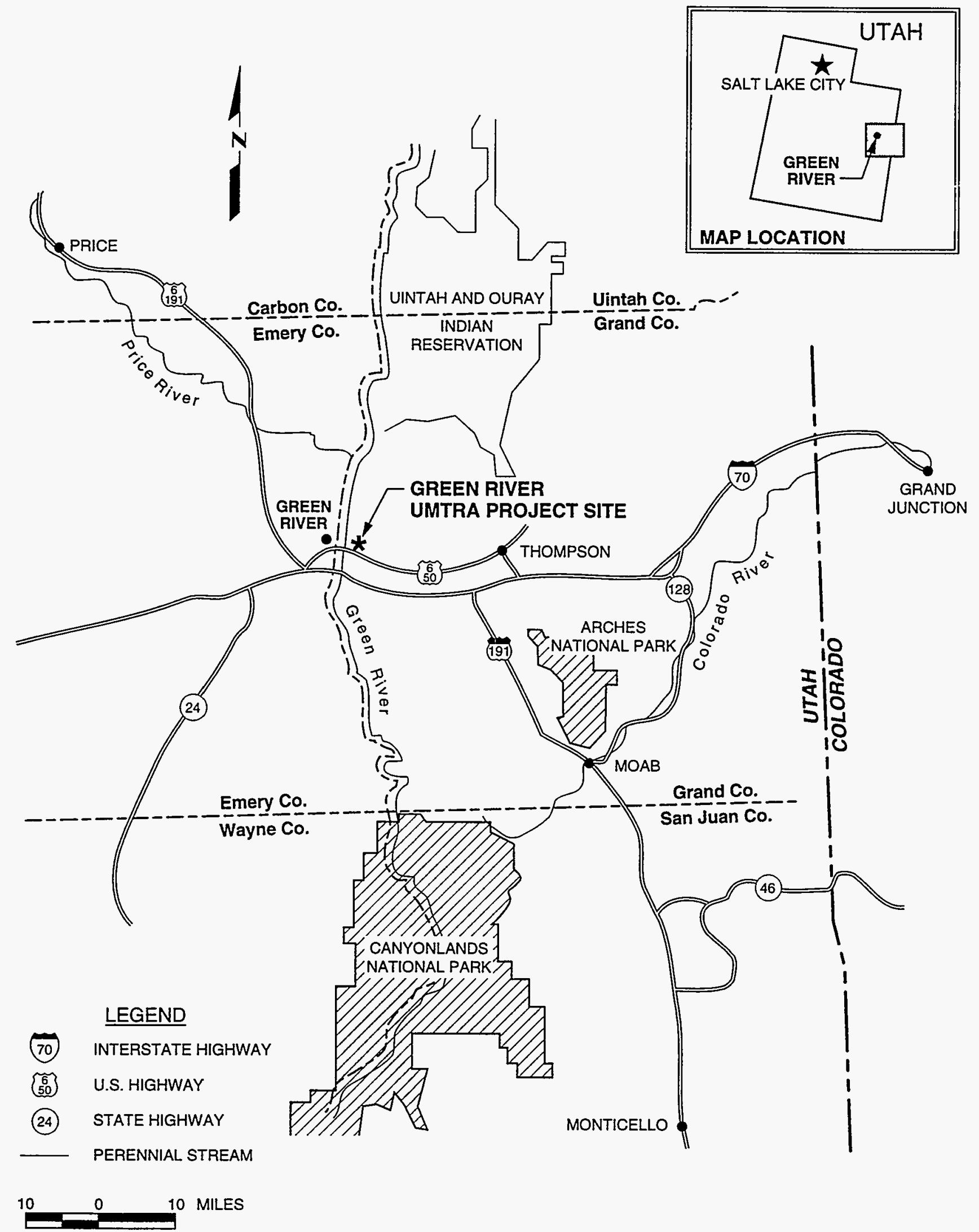

$10 \quad 0 \quad 10$ KILOMETERS

FIGURE 2.1

GREEN RIVER SITE LOCATION MAP GREEN RIVER, UTAH, SITE 


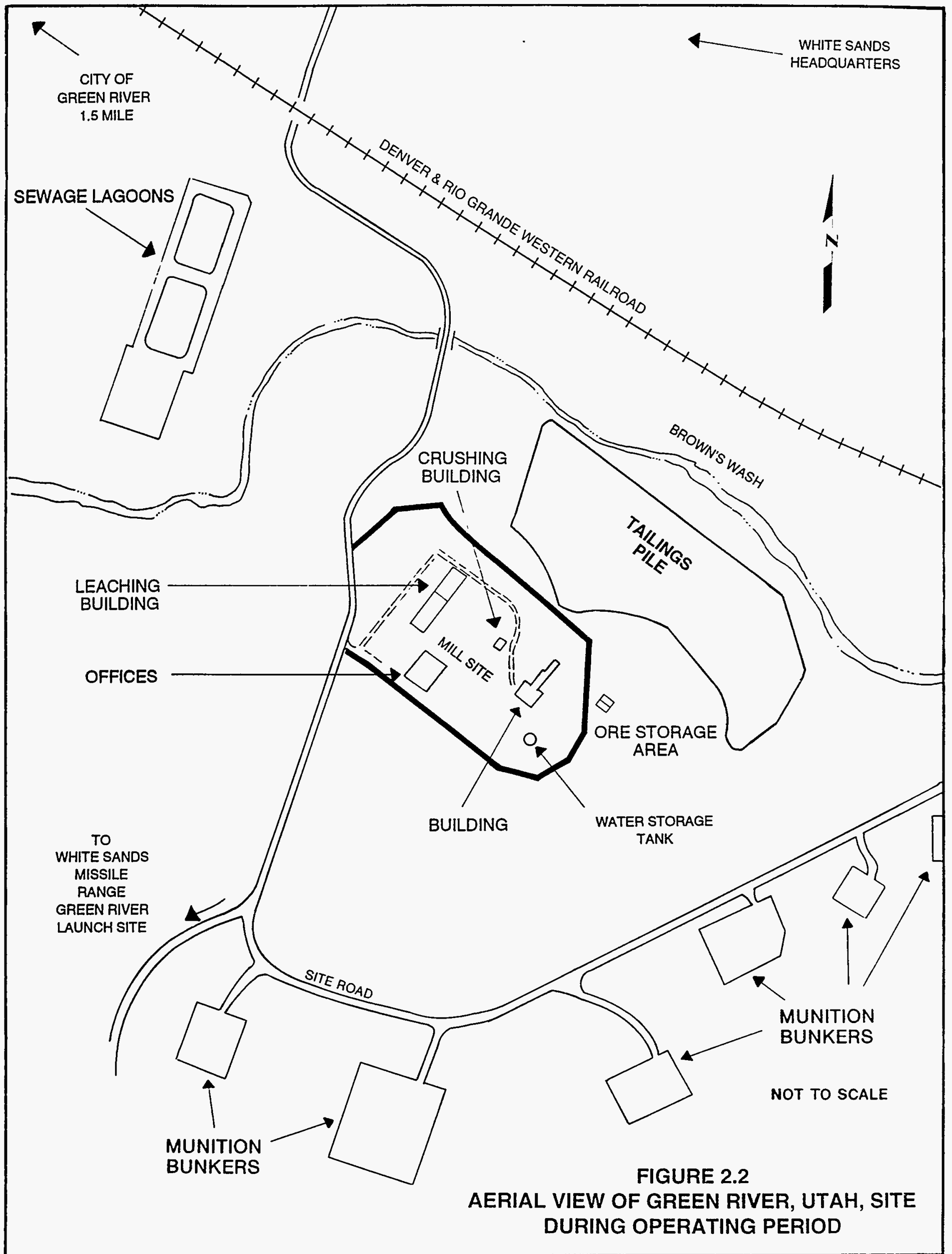


grade, and contaminated materials were emplaced in this cell to approximately $40 \mathrm{ft}(12 \mathrm{~m})$ above grade (Figure 2.3). The disposal cell covers approximately $8 \mathrm{ac}(3 \mathrm{ha})$ and is approximately $600 \mathrm{ft}(180 \mathrm{~m})$ along each side. The area of the former tailings pile and all areas disturbed at the site by remedial action were backfilled, graded to promote surface drainage, and revegetated.

The site is currently being monitored according to the long-term surveillance plan for the Green River, Utah, disposal site (DOE, 1994b). The U.S. Nuclear Regulatory Commission (NRC) and the state of Utah concurred with the DOE's remedial action plan (RAP) (DOE, 1991) under the requirements of the EPA's proposed standards in 40 CFR Part 192, Subpart A. NRC concurrence is based on a two-step process (10 CFR Part 40), with step two addressing residual ground water contamination created by the milling process prior to tailings disposal. Ground water compliance and documentation of activities at the processing site, as required under Subpart B of 40 CFR Part 192, will be implemented under the second phase of the Project and will be addressed under a separate National Environmental Policy Act process. All other agreements with the NRC regarding the final Green River RAP (DOE, 1991) have either been met or the DOE has provided detailed information and justification for an alternative approach that ensures compliance with the EPA standards (NRC, 1990).

\subsection{CLIMATE}

The climate of the Green River site area is arid. Average annual rainfall at the Green River site is 6 inches (15 centimeters [cm]) (USGS, 1982). Average annual evaporation totals approximately 60 inches $(150 \mathrm{~cm})$. High-intensity rainfall in thunderstorms can be expected in the Green River area from July through October.

Prevailing winds are from the south and southwest. Average monthly temperatures range from 23.1 degrees Fahrenheit $\left({ }^{\circ} \mathrm{F}\right)(-4.9$ degrees Celsius $\left[{ }^{\circ} \mathrm{C}\right]$ ) in January to $78.0^{\circ} \mathrm{F}\left(25.6^{\circ} \mathrm{C}\right)$ in July (NOAA, 1980$)$.

\subsection{HYDROGEOLOGY}

Three water-bearing units are defined at the Green River site within $200 \mathrm{ft}$ $(60 \mathrm{~m})$ of land surface. These units are as follows in descending order of depth:

- The top hydrostratigraphic unit, composed of the terrace and Brown's Wash alluviums.

- The middle hydrostratigraphic unit, composed of sandstones, siltstones, shales, and limestones of the upper portion of the Cedar Mountain Formation.

- The lower hydrostratigraphic unit, composed of the Buckhorn Conglomerate Member of the Cedar Mountain Formation. 


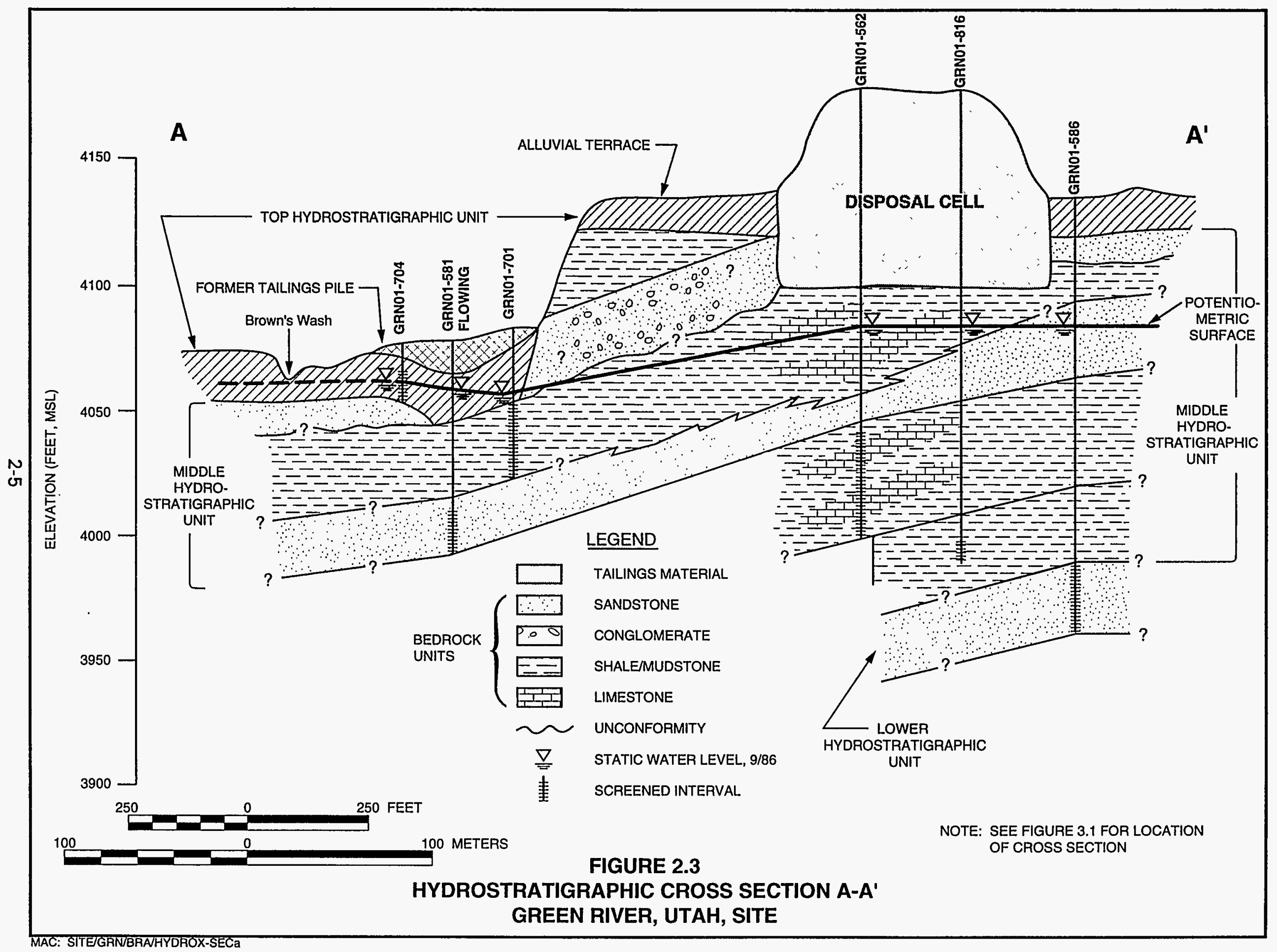


Figure 2.3 shows the relationship between the geologic material, water table, and disposal cell location.

\section{Top hydrostratigraphic unit (Brown's Wash and terrace alluviums)}

The top hydrostratigraphic unit is composed of the Brown's Wash alluvium and terrace alluvium. The Brown's Wash alluvium is a mixture of silt, sand, and gravel derived from erosion along the wash. Silt and sand deposited at higher elevations form an alluvial terrace that is also considered part of the top hydrostratigraphic unit. These deposits are not saturated around the site; therefore, they will not be discussed further.

The Brown's Wash and terrace alluviums overlie bedrock. The alluvium was removed in the disposal cell area during cell construction (see Figure 2.3). The top hydrostratigraphic unit ranges in thickness from 0 to $30 \mathrm{ft}(0 \mathrm{~m}$ to $9 \mathrm{~m})$. Ground water is encountered from 8 to $16 \mathrm{ft}(2.5$ to $4.5 \mathrm{~m})$ below ground surface. Ground water in the top hydrostratigraphic unit is under water table conditions, and the alluvium along Brown's Wash is the ground water flow pathway for ground water contamination from the former tailings site to potentially reach the Green River.

The Brown's Wash alluvium underlies the former processing site tailings area and exists along Brown's Wash and its narrow floodplain. The alluvium is limited to an area that extends approximately 300 to $400 \mathrm{ft}(90$ to $120 \mathrm{~m})$ on either side of Brown's Wash. The saturated extent of the alluvium along the wash is about $200 \mathrm{ft}(60 \mathrm{~m})$ on either side of the centerline of the wash. The saturated extent of the Brown's Wash alluvium is less than the complete extent. The alluvium likely receives ground water recharge from underlying units. Data supporting this interpretation are shown in Figure 2.3. Note that the water levels in wells 701 and 581 are above the top of bedrock and extend into the alluvium in the wash. This is because land surface elevation has changed faster than the potentiometric surface, allowing the two to intersect. This phenomenon provides the mechanism for ground water to discharge from the deeper units to the alluvium along Brown's Wash.

The water table surface for the top hydrostratigraphic unit in January 1988 is shown in Figure 2.4. A more recent map cannot be constructed because most of the site wells located on and adjacent to the mill tailings were decommissioned during remediation. As can be seen in Figure 2.4, ground water flows along the wash to the west-northwest, constrained by the channel of the wash. The average linear ground water velocity has been estimated at $1 \mathrm{ft}(0.4 \mathrm{~m})$ per day or $408 \mathrm{ft}(130 \mathrm{~m})$ per year for this unit (DOE, 1991). Aquifer yield has not been established for the top hydrostratigraphic unit. In October 1987 (DOE, 1991), the wells located farthest down the wash toward the Green River were dry, suggesting that the alluvium along Brown's Wash may not be saturated along its full length to the Green River. Insufficient data exist to know for certain whether the alluvium is continuously saturated to the 


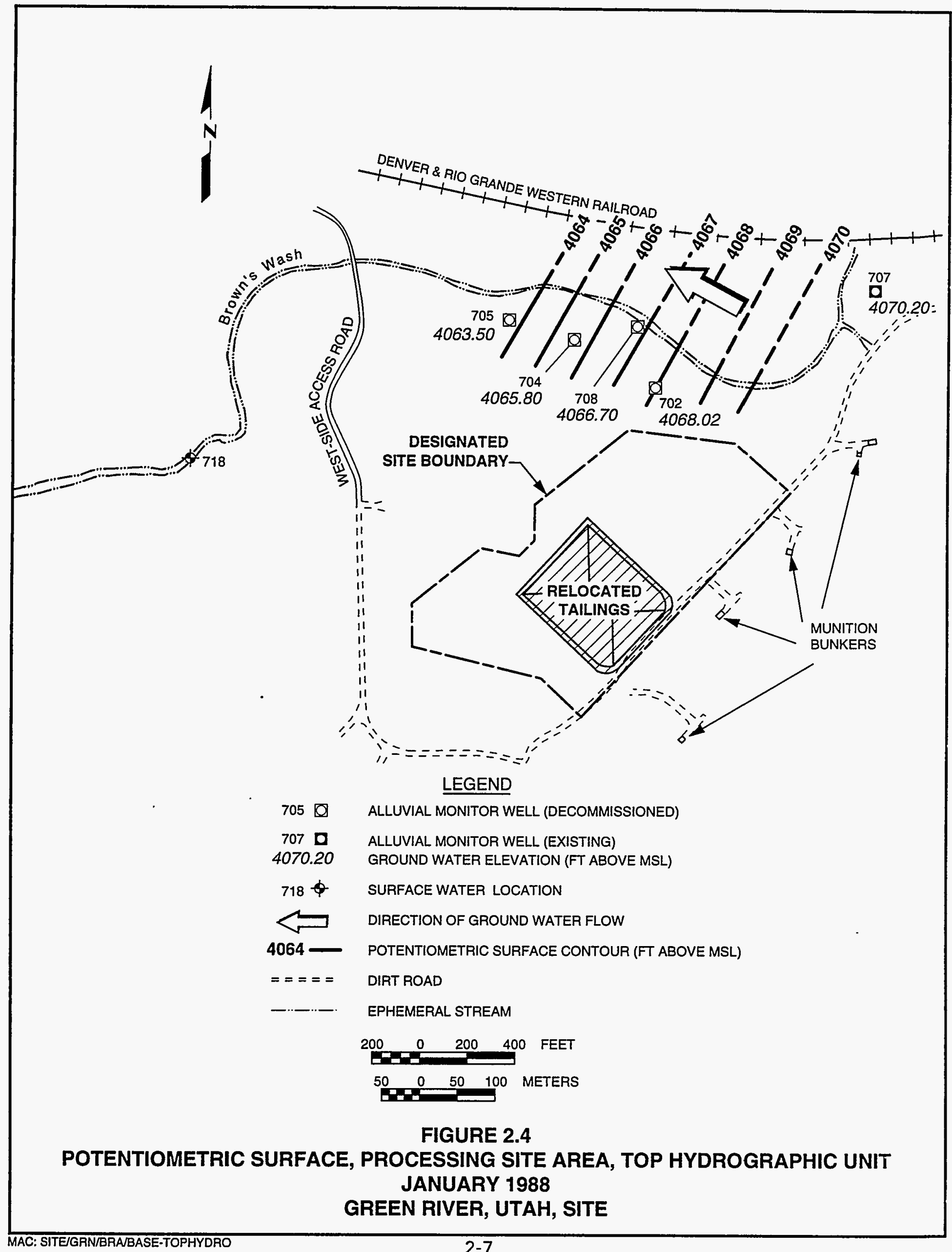


river. Nonetheless, it has been assumed that there is a continuous pathway for ground water in the Brown's Wash alluvium to the Green River.

\section{Middle hydrostratigraphic unit (Upper Cedar Mountain Formation)}

The unnamed middle hydrostratigraphic unit consists of fine-grained rocks (siltstones, mudstones, and limestones) and sandstones of the Upper Cedar Mountain Formation. The fine-grained rocks have a low hydraulic conductivity; consequently, well yield is also low. The sandstones have a higher hydraulic conductivity than the fine-grained rocks, with correspondingly greater well yield. The ground water potentiometric surface ranges between 3 to $60 \mathrm{ft}(1$ to $20 \mathrm{~m})$ below ground surface. Ground water in the middle hydrostratigraphic unit exists under confined and semiconfined conditions, with well 581 exhibiting artesian flow where the water pressure in the ground causes the water in the well to flow freely at land surface.

The potentiometric surface for the middle hydrostratigraphic unit beneath and surrounding the disposal cell area in October 1993 is shown in Figure 2.5. Figure 2.3 shows the relation of the disposal cell to the ground water flow system. The ground water flow direction in the disposal cell area is toward the northwest. This flow pattern is a result of the combination of the recharge taking place at higher elevations, recharge from underlying downdipping aquifers, and the dip of the formation (Figure 2.3). In areas topographically higher than Brown's Wash, the alluvium of the top hydrostratigraphic unit is unsaturated, and the ground water flow system lies entirely within the middle and lower hydrostratigraphic units.

A pumping test was performed on the Upper Cedar Mountain formation in October 1993 (calculation no. GRN-01-11-93-14-09-00) (TAC, 1993a) at a constant rate of 4 gallons (15 liters [L]) per minute, which yielded a drawdown of $1.5 \mathrm{ft}(0.45 \mathrm{~m})$ after 70 hours. This pumping rate gives a daily volume of 5760 gallons $(21,800 \mathrm{~L})$, which is much greater than the regulatory household supply volume of 150 gallons $(570 \mathrm{~L}$ ) per day for Class III designation based on yield (EPA, 1986). Thus, the Upper Cedar Mountain could provide 150 gallons $(570 \mathrm{~L})$ per day with drawdown of less than $1 \mathrm{ft}(0.3 \mathrm{~m})$.

The middle hydrostratigraphic unit may be a pathway for ground water migrating from the processing site area. Erosion along Brown's Wash has caused the land surface to drop near or below the potentiometric surface of the middle unit, creating the potential for upward flow from the middle to the top unit along portions of the wash. Because there is some potential for the middle hydrostratigraphic unit to discharge ground water to the top unit, the middle unit must also be considered a pathway to the sporadic surface water found along Brown's Wash (e.g., surface sampling location 718 in Figure 2.4). The average linear ground water velocity for this unit in the disposal cell area has been estimated at $0.14 \mathrm{ft}(0.05 \mathrm{~m})$ per day, or $50 \mathrm{ft}(15 \mathrm{~m})$ per year (DOE, 1991). 


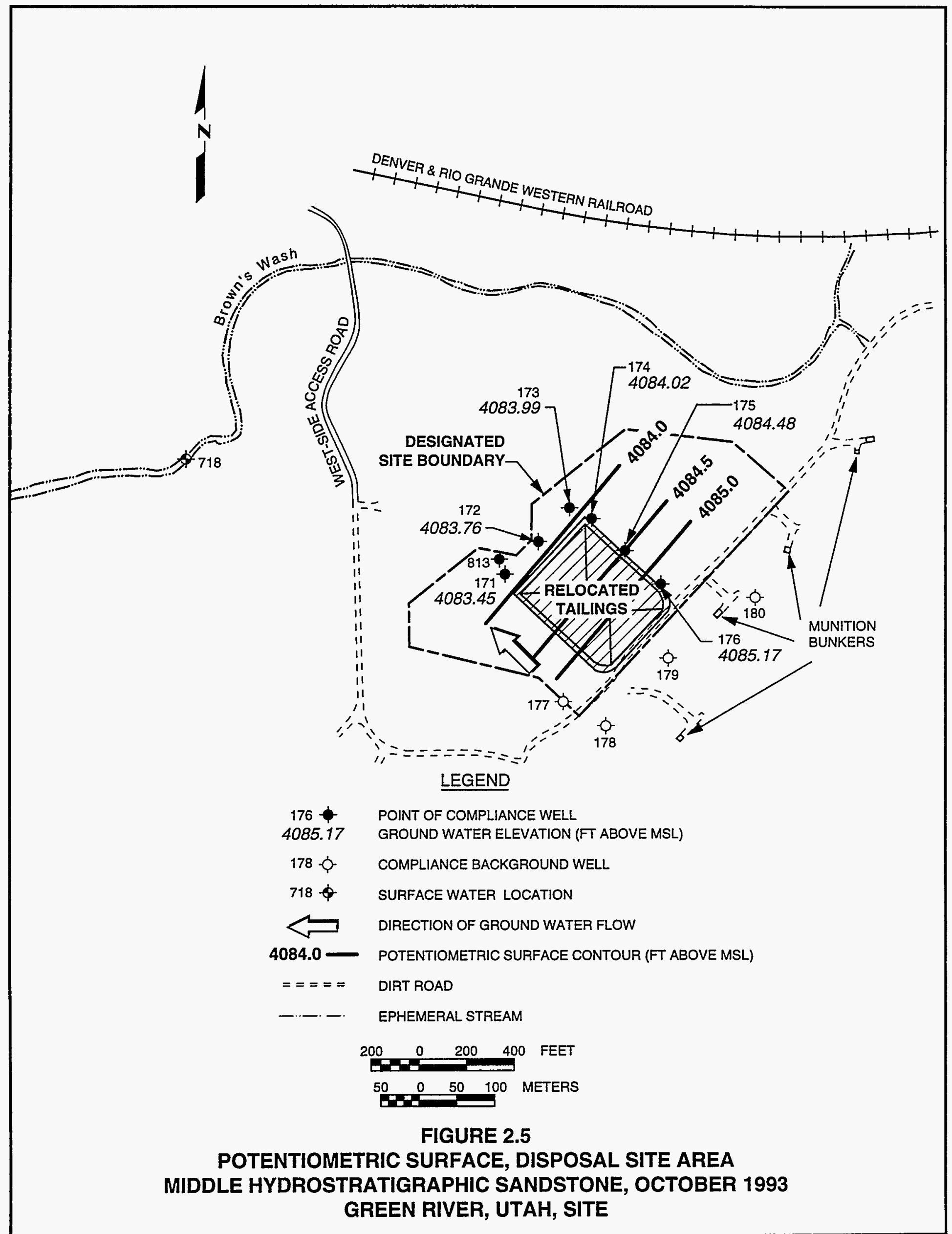




\section{Lower hydrostratigraphic unit}

The lower hydrostratigraphic unit is composed of the Buckhorn Member of the Cedar Mountain Formation. The Buckhorn Member ranges in thickness from 15 to $25 \mathrm{ft}(5$ to $8 \mathrm{~m}$ ) in the site area. Ground water levels range from $80 \mathrm{ft}$ $(24 \mathrm{~m})$ below ground surface to above ground surface (artesian flow).

Hydraulic properties, ground water flow directions, and ground water flow velocities have not been reliably established for this unit. The geologic configuration of this unit is similar to the middle hydrostratigraphic unit; therefore, ground water in the lower hydrostratigraphic unit probably flows to the northwest as well.

Three pairs of Buckhorn and Upper Cedar Mountain wells were examined to evaluate the vertical hydraulic gradient between the units. Water levels recorded in October 1987 were used in the analysis. The vertical distance was determined by computing the elevation of the center of the screened interval for each well and subtracting the elevations for each pair. The results are summarized in Table 2.1.

As can be seen in Table 2.1, the hydraulic gradients are strongly upward. Therefore, the lower hydrostratigraphic unit is protected from site-related contamination by strong upward hydraulic gradients and overlying shales and mudstones (DOE, 1991).

Table 2.1 Ground water elevations, Green River, Utah, site

\begin{tabular}{lcc}
\hline \multicolumn{1}{c}{ Wells gradient } & Water elevation (ft MSL) & Upward gradient (ft/ft) \\
\hline 582 (Buckhorn) & 4080 & 0.26 \\
583 (Upper Cedar Mountain) & 4048 & \\
819 (Buckhorn) & 4080 & 0.19 \\
584 (Upper Cedar Mountain) & 4058 & \\
586 (Buckhorn) & 4086 & 0.03 \\
816 (Upper Cedar Mountain) & 4083 & \\
\hline
\end{tabular}

MSL-mean sea level.

The transmissivity of the Buckhorn Formation is similar to that of the Upper Cedar Mountain (DOE, 1991); consequently, similar drawdown from a household supply well would be anticipated. The drawdown caused by a single household supply well would not be enough to reverse the vertical hydraulic gradient observed between the Upper Cedar Mountain and the Buckhorn Formations. However, large-scale exploitation of the Buckhorn Formation could cause gradient reversal. It is unlikely that such exploitation would occur in the future because of the stable demographics and land use in the site area; therefore, future downward migration is not a concern. 


\subsection{SURFACE WATER}

Surface water features in the vicinity of the Green River site include the Green River, Brown's Wash, and several ephemeral drainages (Figure 2.6). The site is $0.5 \mathrm{mi}(0.8 \mathrm{~km})$ east of the Green River, which drains southward and southeastward from the site area and joins the Colorado River 60 air mi 196 air $\mathrm{km}$ ) south of the site. The Green River has a drainage area of 24,900 square miles $\left(\mathrm{mi}^{2}\right)\left(65,000\right.$ square kilometers $\left.\left[\mathrm{km}^{2}\right]\right)$. Brown's Wash, an ephemeral tributary of the Green River, borders the site on the north. The wash has a drainage area of $52 \mathrm{mi}^{2}\left(136 \mathrm{~km}^{2}\right)$ in the vicinity of the site.

Runoff from the former processing site area is directed northwest to Brown's Wash and from there into the Green River. Surface runoff from the disposal cell area flows over the former processing site area into Brown's Wash and from there into the Green River. Surface runoff north of the site is diverted from Brown's Wash and the site area by a railroad embankment $30 \mathrm{ft}(9 \mathrm{~m})$ north of Brown's Wash (Figure 2.6).

A U.S. Geological Survey (USGS) gauging station on the Green River near the city of Green River is $3200 \mathrm{ft}(975 \mathrm{~m})$ upstream from the confluence with Brown's Wash. The recorded average maximum monthly flow was 24,480 cubic feet $\left(\mathrm{ft}^{3}\right)$ per second (2.5 million cubic meters $\left[\mathrm{m}^{3}\right.$ ] per hour); the average mean monthly flow was $18,580 \mathrm{ft}^{3}$ per second $\left(1.9 \mathrm{~m}^{3}\right.$ per hour) (DOE, 1993a). On June 27, 1917, a peak flow of $68,100 \mathrm{ft}^{3}$ per second $(6.9$ million $\mathrm{m}^{3}$ per hour) was recorded.

Because Brown's Wash is ephemeral, there is no surface water flow in the wash most of the year. During and after rainfall events of sufficient magnitude, surface water flows through the wash. The flow consists of surface runoff and may also consist of ground water discharging from the alluvium and underlying units. The Green River likely acts as a regional ground water discharge area.

\section{$2.5 \quad$ LAND USE}

The Green River site is located approximately $1 \mathrm{mi}(1.6 \mathrm{~km})$ southeast of the city of Green River and within $0.5 \mathrm{mi}(0.8 \mathrm{~km})$ of the community of Elgin (Figure 2.7).

The 48-ac (19-ha) disposal site is bordered by the mainline track of the Denver and Rio Grande Western (D\&RGW) Railroad on the north and Interstate 70 on the south. The state of Utah acquired ownership of the former mill and tailings site in 1988. Upon completion of the remedial action, legal title to the disposal site will be conveyed to the federal government (DOE, 1991; 1994b).

Green River is a small community of about 700 residents on the border of Emery and Grand Counties, Utah. That number can increase to as much as 1300 in the summer (TAC, 1993b). The economy depends mainly on tourism and agriculture. The main crops are melons, corn, and hay. 


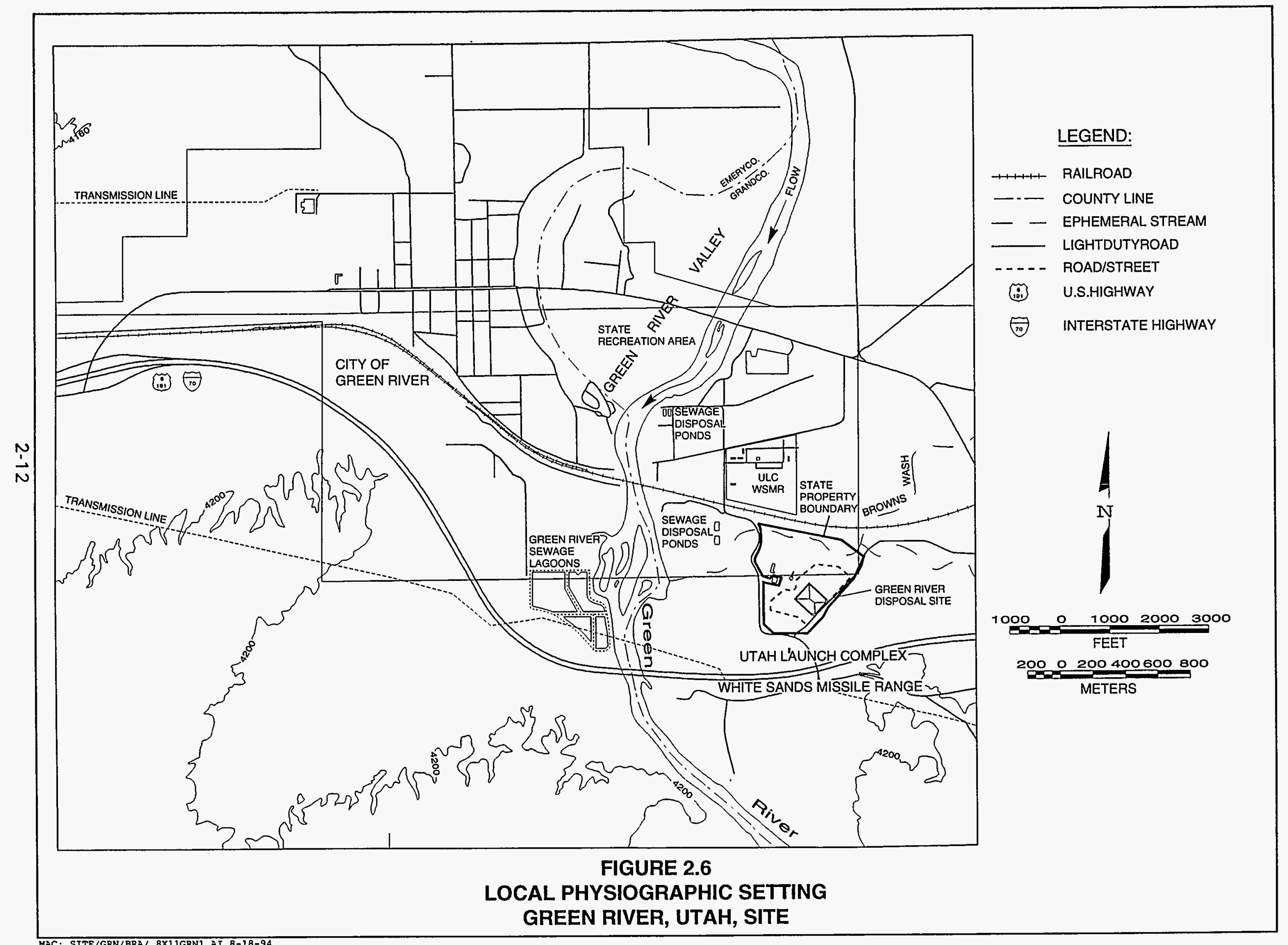




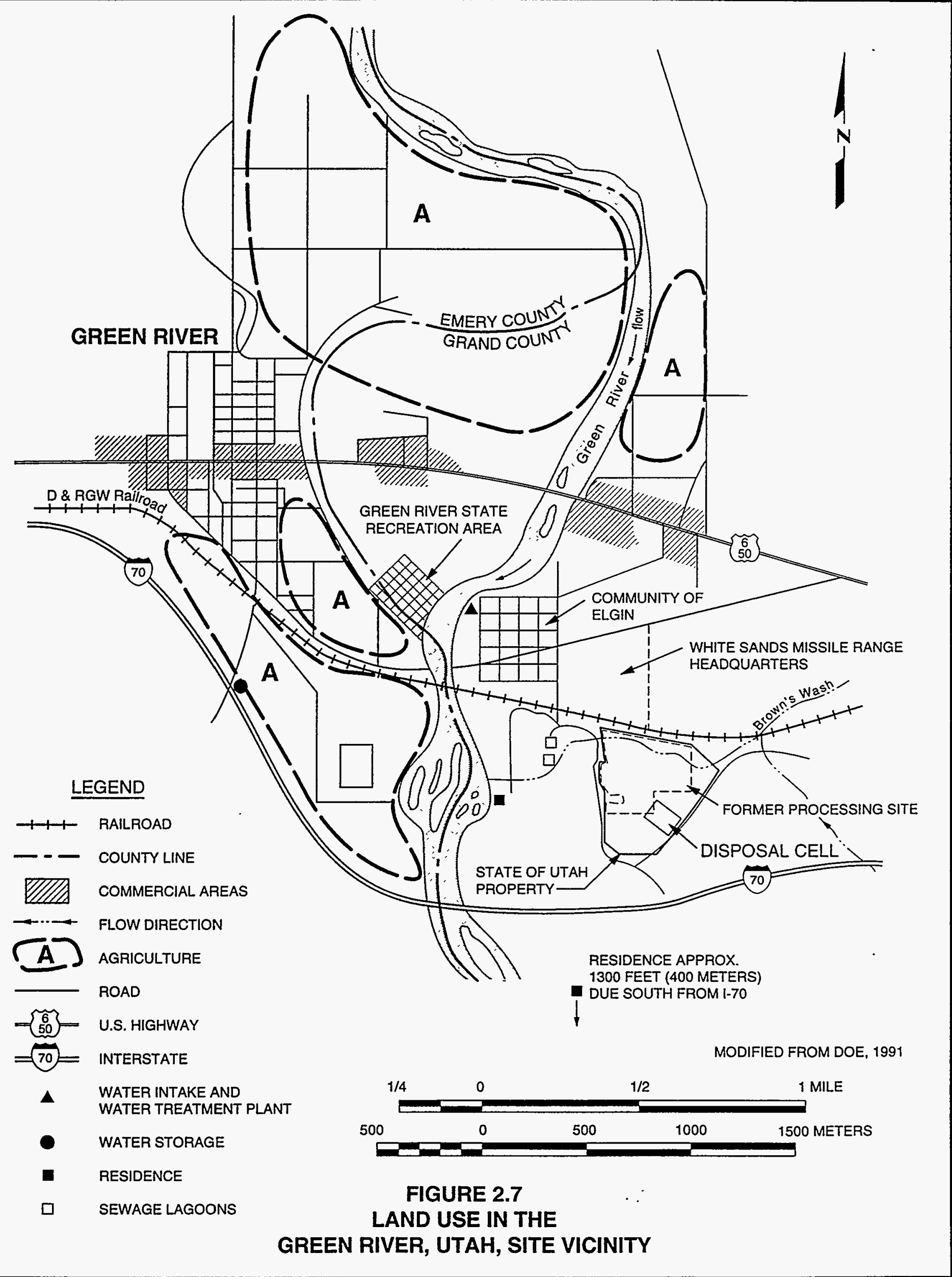


There are 13 occupied houses and trailers and 4 abandoned residences in the unincorporated area of Elgin northwest of the site. The population of Elgin is estimated to be about 30 people, including about 10 children (TAC, 1993b). There are two more residences near the site. The nearest is approximately $0.25 \mathrm{mi}(400 \mathrm{~m})$ southwest of the site. The second is about $3000 \mathrm{ft}(0.9 \mathrm{~km})$ south of the site and about $1300 \mathrm{ft}(0.4 \mathrm{~km})$ south of Interstate 70 . Some of the residents raise horses, grow pasture grasses, and cultivate small vegetable gardens.

The U.S. Army White Sands Missile Test Range and Headquarters Control uses most of the vacant land south and east of the disposal site (Figure 2.7). The headquarters military facility, located immediately northwest of the disposal site, includes several large buildings and approximately 70 mobile homes, none of which are occupied. These facilities are currently used by local construction companies to obtain sand and gravel materials (DOE, 1993b). Six former munition bunkers are located immediately south and southeast of the site between the site road and Interstate 70 (Figure 2.2). These munition bunkers are abandoned now. The exact use of these bunkers is not known. Although operations at the missile range and headquarters have been discontinued, they may resume in the future. Remaining land south and west of the site is owned either by the city or by private owners. The private land is used for grazing or sits idle.

There is some commercial activity along the major highways in the city of Green River. Approximately $1 \mathrm{mi}(1.5 \mathrm{~km})$ east of the Green River, along Highway 6 and 50, there are two motels, restaurants, and a campground for trailers and mobile homes.

\subsection{WATER USE}

Ten registered private water wells and one well owned by the state of Utah have been identified within a $2-\mathrm{mi}(3-\mathrm{km})$ radius of the former uranium processing site. The locations of these wells are shown in Figure 2.8. Most of them are west of the Green River, which likely acts as a barrier for contaminant plume migration to the north and northwest. Except for the well owned by the state of Utah (well 11), most of these wells are shallow and are believed to be completed in the alluvium of the Green River floodplain (Table 2.2). Well 11 $(1360 \mathrm{ft}[400 \mathrm{~m}]$ deep) is completed in the Entrada Sandstone. Discussion with the water superintendent for the city of Green River indicated that this well is not being used because its exploitation is too expensive (TAC, 1994a). Because of the poor quality of water in the region and the availability of good quality water from the municipal water supply system or the Green River, these wells are not being used as a drinking water resource (TAC, 1993b). No water quality data are available for the shallow private ground water wells at this time. Some of these wells are unusable due to mechanical constraints, and some of them are reported to be used as a source of water for stock and lawns or domesticgarden irrigation. 


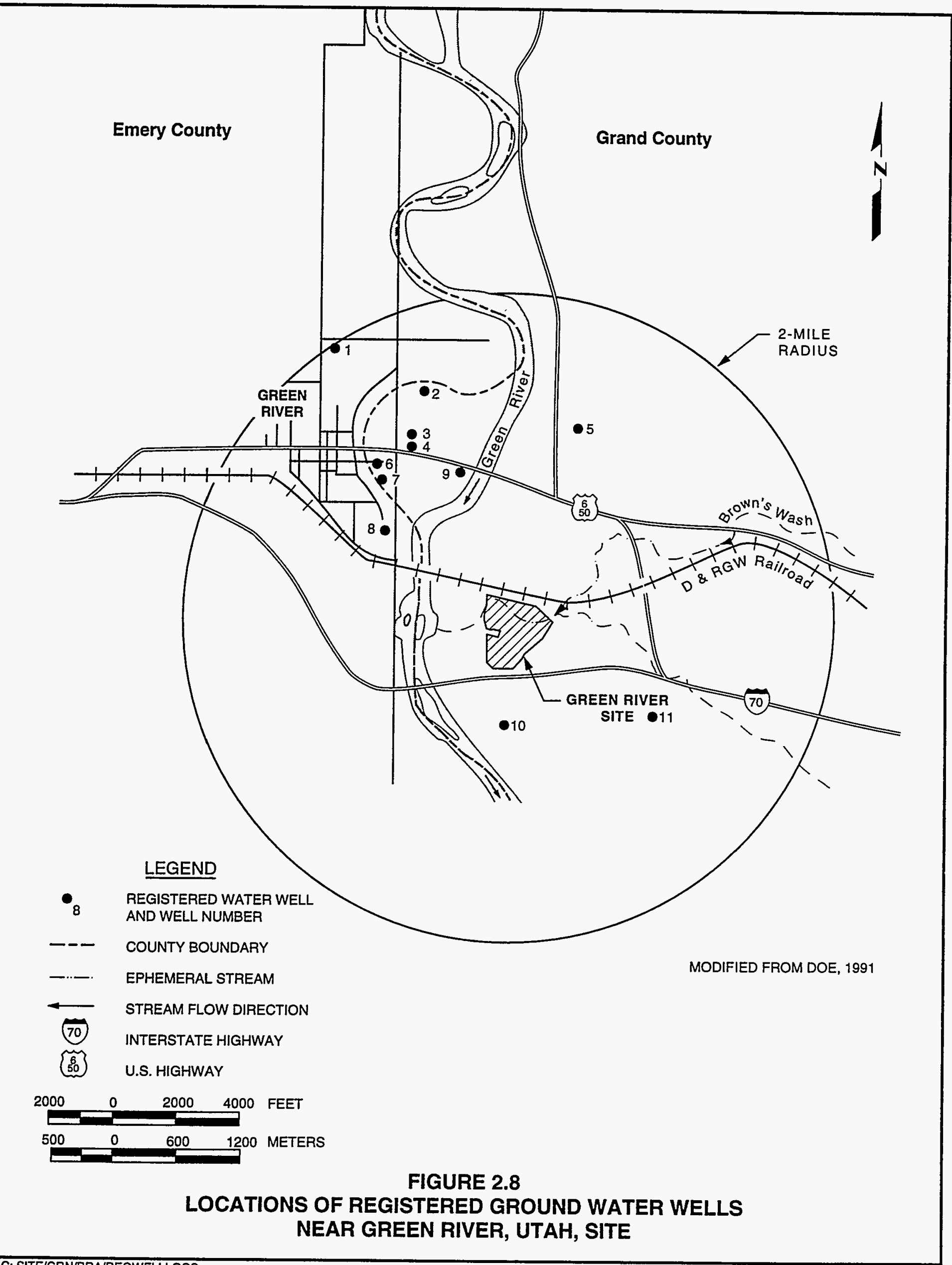




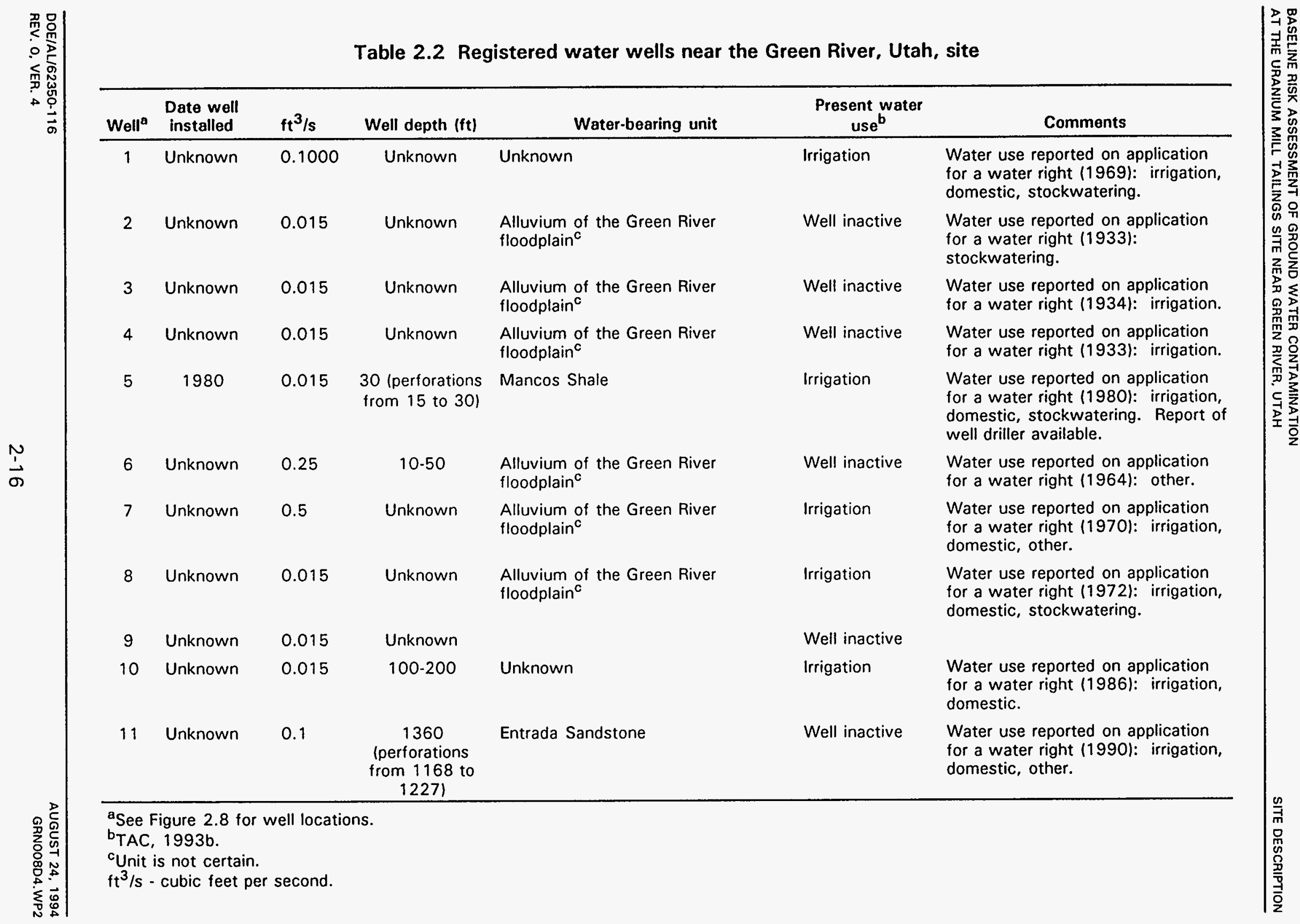


Residents of the city of Green River and community of Elgin are connected to the municipal water supply system. The source of water for the municipal water supply system is the Green River. Two residences shown in Figure 2.7 (one west of the site and the other south of Interstate 70) are not connected to the system. The residents haul water for domestic purposes from the city water supply system and store it in water tanks (TAC, 1993b).

A water intake station from the Green River and a water treatment plant are located upstream and upgradient, approximately $0.75 \mathrm{mi}(1.2 \mathrm{~km})$ from the northwestern boundary of the site. The water treatment plant can treat about 1.5 million gallons (5.7 million L) of water per day (TAC, 1993b). Water storage tanks for the municipal water supply system can store about 500,000 gallons ( 2 million $L$ ) and are located south of the city of Green River, near Interstate 70 (Figure 2.7).

Maximum daily water use by the city of Green River is estimated to be about 800,000 gallons ( 3 million $L$ ) in summer and about 200,000 gallons $(800,000 \mathrm{~L}$ ) in winter. Maximum daily water use by the community of Elgin and by the motels, restaurant, and campground east of the Green River is estimated to be about 20,000 gallons $(80,000 \mathrm{~L})$ in summer and 5000 gallons $(20,000 \mathrm{~L})$ in winter.

The majority of irrigation water is supplied by the Green River Canal Company from the Green River (TAC, 1993b). Irrigation water is supplied through a drainage canal that follows the river in the city area. The river irrigation water is used by area residents for agricultural and domestic-garden purposes.

There are no known current uses of surface water or ground water along Brown's Wash (an ephemeral tributary of the Green River) in the vicinity of the site. However, no barrier exists to prevent access to surface water along Brown's Wash by domestic stock or wildlife. 


\subsection{EXTENT OF CONTAMINATION}

Water quality data from the Buckhorn Member of the Cedar Mountain Formation show that contamination from the former uranium processing site is not reaching that water-bearing unit now, nor has entered it in measurable quantities in the past. Therefore, this unit will not be discussed further in this document.

Two water-bearing units that remain relevant for assessing risk at the former Green River processing site are 1) the alluvial aquifer beneath the former tailings pile adjacent to Brown's Wash (Brown's Wash alluvium), and 2) the upper unit of the Cedar Mountain Formation (Upper Cedar Mountain aquifer). Filtered water samples from 32 monitor wells were used to characterize the nature and extent of contamination in ground water beneath the site. The locations of the monitor wells are shown in Figure 3.1. Monitor well information, including the formation of completion, screened interval, flow relationship, and sampling frequency for select locations, is provided in Table 3.1.

Surface water from the Green River has been sampled upstream (location 801) and downstream (location 802) from its confluence with Brown's Wash and from Brown's Wash (locations 526, 709, 710, 711, and 718). Surface water sampling locations are shown in Figure 3.1; location identifications, years sampled, and number of sampling rounds are presented in Table 3.1. Water quality data based on filtered water samples from the Green River and both filtered and unfiltered water samples from Brown's Wash were used in the risk assessment.

Water samples were collected following applicable standard operating procedures (SOP) in the Albuquerque Operations Manual (JEG, n.d.).

Generally, as a result of the milling process, constituents expected to be found in ground water beneath the Green River site include 1) chemicals used in the milling process (i.e., sulfuric acid [as sulfate], sodium chlorate [as sodium and chloride], and ammonia [oxidized to nitrate]), 2) trace elements associated with uranium ore (i.e., arsenic, manganese, molybdenum, selenium, vanadium, and uranium), and 3) radionuclides (such as uranium234 and -238 ) and their decay products (such as lead-210, polonium-210, radium-226, and thorium-230). A detailed description of the milling process can be found in Section 2.1.

\subsection{BACKGROUND WATER QUALITY SUMMARY}

Background water quality is defined as the quality of water if uranium milling activities had not taken place. Background ground water quality is discussed for both units (alluvial system and the Upper Cedar Mountain Formation).

\subsubsection{Alluvial system}

There are currently no background ground water quality data for the alluvial system. The only upgradient monitor well screened in the alluvium is monitor well 707 (Figure 3.1). Water quality analysis of ground water from monitor well 


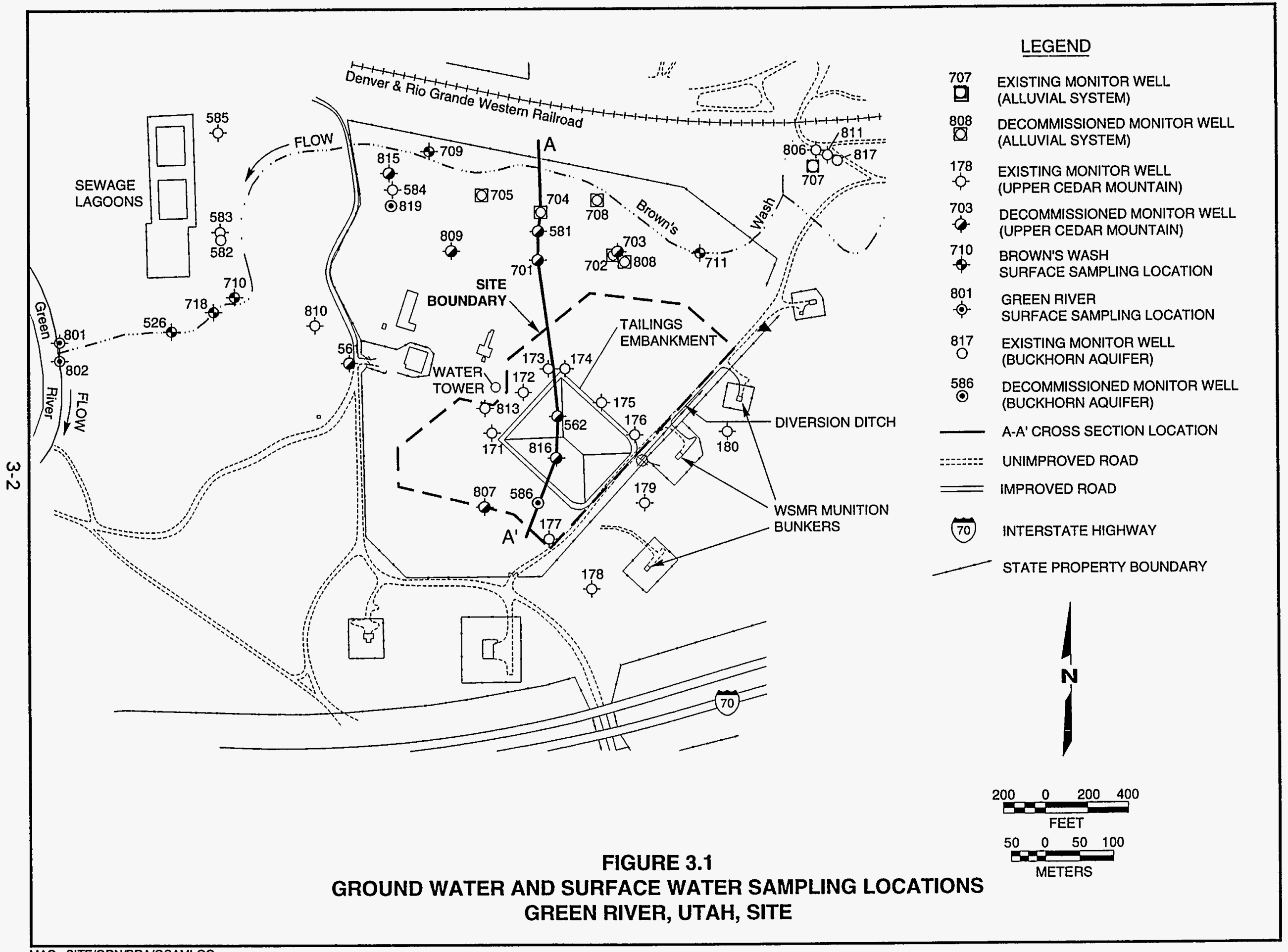


Table 3.1 Monitor well and surface water sampling information for the Green River, Utah, site

\begin{tabular}{|c|c|c|c|c|}
\hline Location ID & $\begin{array}{c}\text { Screened } \\
\text { interval } \\
(\mathrm{ft})\end{array}$ & $\begin{array}{c}\text { Flow } \\
\text { relationship }\end{array}$ & Years sampled & $\begin{array}{c}\text { Number of } \\
\text { sampling } \\
\text { rounds }\end{array}$ \\
\hline \multicolumn{5}{|l|}{ Alluvial wells } \\
\hline 702 & $15-23$ & On-site & $1986-1988$ & 5 \\
\hline 704 & $15-23$ & On-site & $1986-1988$ & 4 \\
\hline 705 & $14-20$ & On-site & $1986-1988$ & 6 \\
\hline 707 & $9-15$ & Upgradient & $1986-1992$ & 16 \\
\hline 708 & $7-11$ & On-site & $1986-1988$ & 3 \\
\hline 808 & $12-23$ & On-site & $1987-1988$ & 2 \\
\hline \multicolumn{5}{|c|}{ Upper Cedar Mountain Formation } \\
\hline 171 & $76-86$ & On-site & $1990-1993$ & 8 \\
\hline 172 & $84-89$ & On-site & $1990-1993$ & 8 \\
\hline 173 & $92-102$ & On-site & $1990-1993$ & 8 \\
\hline 174 & $73-83$ & On-site & $1990-1993$ & 8 \\
\hline 175 & $78-88$ & On-site & $1990-1993$ & 8 \\
\hline 176 & $72-82$ & On-site & $1990-1993$ & 8 \\
\hline 177 & $103-113$ & On-site & $1990-1993$ & 8 \\
\hline 178 & $98-108$ & Upgradient & $1990-1993$ & 8 \\
\hline 179 & $78-88$ & Upgradient & $1990-1993$ & 8 \\
\hline 180 & $78-88$ & Upgradient & $1990-1993$ & 8 \\
\hline 561 & $109-139$ & Downgradient & $1986-1988$ & 5 \\
\hline 562 & $85-125$ & On-site & $1986-1988$ & 6 \\
\hline 581 & $63-83$ & On-site & $1986-1988$ & 5 \\
\hline 583 & $28-48$ & Downgradient & $1986-1992$ & 15 \\
\hline 584 & $28-48$ & On-site & $1986-1992$ & 15 \\
\hline 585 & $38-48$ & Downgradient & $1986-1992$ & 15 \\
\hline 701 & $29-57$ & On-site & $1986-1988$ & 6 \\
\hline 703 & $22-28$ & On-site & $1986-1987$ & 3 \\
\hline 806 & $87-92$ & Crossgradient & $1987-1992$ & 13 \\
\hline 807 & $78-98$ & On-site & $1987-1990$ & 7 \\
\hline
\end{tabular}


Table 3.1 Monitor well and surface water sampling information for the Green River, Utah, site (Concluded)

\begin{tabular}{|c|c|c|c|c|}
\hline Location ID & $\begin{array}{c}\text { Screened } \\
\text { interval } \\
(\mathrm{ft})\end{array}$ & $\begin{array}{c}\text { Flow } \\
\text { relationship }\end{array}$ & Years sampled & $\begin{array}{c}\text { Number of } \\
\text { sampling } \\
\text { rounds }\end{array}$ \\
\hline 809 & $48-68$ & On-site & $1987-1988$ & 2 \\
\hline 810 & $58-78$ & Downgradient & $1987-1992$ & 13 \\
\hline 811 & $63-78$ & Crossgradient & $1987-1992$ & 13 \\
\hline 813 & $78-98$ & Downgradient & $1987-1993$ & 15 \\
\hline 815 & $88-98$ & Downgradient & $1987-1988$ & 3 \\
\hline 816 & $48-58$ & On-site & $1987-1988$ & 2 \\
\hline \multicolumn{5}{|c|}{ Surface water sampling locations } \\
\hline \multicolumn{5}{|l|}{ Green River } \\
\hline 801 & NA & Upstream & $1986-1992$ & 19 \\
\hline 802 & NA & Downstream & $1986-1992$ & 15 \\
\hline \multicolumn{5}{|c|}{ Brown's Wash } \\
\hline 526 & NA & Downstream & $1982-1993$ & 11 \\
\hline 709 & NA & Crossgradient & 1982 - present & 9 \\
\hline 710 & NA & Downstream & $1982-1987$ & 3 \\
\hline 711 & NA & Upstream & 1982 to present & 2 \\
\hline 718 & NA & Downstream & 1993 & 1 \\
\hline
\end{tabular}

NA-Not applicable. 
707 shows that this water is consistently high in nitrate $(9$ to 140 milligrams per liter $[\mathrm{mg} / \mathrm{L}])$, uranium $(0.01$ to $0.03 \mathrm{mg} / \mathrm{L})$, and sulfate $(4800$ to $6500 \mathrm{mg} / \mathrm{L})$, the constituents common to the milling process. Even though monitor well 707 is upgradient from the current tailings area, the presence of these constituents, especially nitrate, in ground water raises suspicion as to whether ground water from this location has been affected by the milling process.

\subsubsection{Upper Cedar Mountain aquifer}

Generally, background ground water in the Upper Cedar Mountain Formation aquifer is a sodium-carbonate-sulfate type characterized by high total dissolved solids (TDS) ( 1700 to $2500 \mathrm{mg} / \mathrm{L}), \mathrm{pH}$ above $8(8.0$ to 8.5$)$, and reduction/oxidation (redox) potential ranging from -300 to +400 millivolts ( $\mathrm{mV}$ ).

The monitor wells investigated as potential background wells include monitor wells 178, 180, 806, and 811. These monitor wells are screened in the Upper Cedar Mountain Formation and are either crossgradient or upgradient from both the tailings area and processing site.

Monitor wells 806 and 811 are near Brown's Wash to the northeast, within $100 \mathrm{ft}(30 \mathrm{~m})$ of each other. Ground water from these wells exhibits very similar water quality (i.e., pH between 7.9 and 8.5 ; alkalinity approximately $1000 \mathrm{mg} / \mathrm{L}$ [as $\mathrm{CaCO}_{3}$ ]; TDS around $2200 \mathrm{mg} / \mathrm{L}$; chloride approximately 140 to $200 \mathrm{mg} / \mathrm{L}$; sodium approximately 800 to $900 \mathrm{mg} / \mathrm{L}$; and low calcium [approximately $5 \mathrm{mg} / \mathrm{L}$ ]). Magnesium and potassium are both around $2 \mathrm{mg} / \mathrm{L}$, and uranium concentrations range from less than $0.001 \mathrm{mg} / \mathrm{L}$ to $0.005 \mathrm{mg} / \mathrm{L}$. Furthermore, concentrations of iron are typically between 0.09 and less than $0.03 \mathrm{mg} / \mathrm{L}$, and manganese concentrations are extremely low (less than or equal to $0.02 \mathrm{mg} / \mathrm{L}$ ). Nitrate concentrations vary from less than 0.1 to $5 \mathrm{mg} / \mathrm{L}$. Sulfate concentrations in well 806 are in the $600-$ to $800-\mathrm{mg} / \mathrm{L}$ range. These levels are slightly higher than sulfate levels in ground water from well 8111300 to $600 \mathrm{mg} / \mathrm{L})$. One redox measurement with a platinum probe suggests strongto-moderate reducing conditions $(-200$ to $-400 \mathrm{mV})$ in ground water in the vicinity of monitor wells 806 and 811 .

Wells 178 and 180 are located east and southeast of the current disposal cell. Water quality measurements from these wells differ somewhat from those of wells 806 and 811 . Ground water from wells 178 and 180 has slightly higher. concentrations of sulfate $(800$ to $1200 \mathrm{mg} / \mathrm{L}$ ), nitrate (concentrations up to $11 \mathrm{mg} / \mathrm{L}$ ), and uranium (up to $0.008 \mathrm{mg} / \mathrm{L}$ ) than ground water from monitor wells 806 and 811 . These differences may reflect natural variation in background water chemistry. However, the proximity of wells 178 and 180 to the upper edge of the processing site and to the munition bunkers and the presence of high levels of site-related constituents in nearby well 179 cast some doubts on these wells as background. Therefore, monitor wells 178 and 180 were not used for the risk assessment. Water quality in monitor well 179 is discussed in more detail in Section 3.2.2. 


\subsection{MAGNITUDE OF SITE-RELATED CONTAMINATION}

Water quality data collected from monitor wells from 1986-1988, prior to surface remediation, indicate that site-related contamination is present in ground water beneath the site in both the alluvial system and the Upper Cedar Mountain Formation. Because no organic solvents or compounds were used in the uranium milling process at the Green River site, only inorganic contamination is present. However, in 1989, ground water at the Green River site was screened for organic compounds listed in Appendix IX of the Resource Conservation and Recovery ACt (RCRA) (42 USC $\$ 6901$ et seq.). The results of the screening were negative, indicating that ground water beneath the site is not contaminated with these organic constituents.

The extent of contamination in ground water for both the alluvial system and the Upper Cedar Mountain aquifer are discussed below. However, because background ground water quality in the alluvial system has not been determined, the impact from the uranium milling process is discussed generally, without reference to background water quality values.

\subsubsection{Alluvial aquifer}

A discussion of the magnitude and extent of contamination in the alluvial aquifer is difficult because 1) there are currently no background data for the alluvial aquifer, 2) the extent to which milling activities have affected the area is not fully characterized, and 3) limited data are available with which to quantify the magnitude of site-related contamination. Additionally, it is not known if the Brown's Wash alluvium ground water represents a substantial water resource.

All of the on-site monitor wells screened in the alluvium $(702,704,705,708$, and 808 in Figure 3.1) were abandoned during surface remediation in 1988. Therefore, water quality data from 1986 to 1988 were used. Table 3.2 summarizes on-site water quality data in the alluvial aquifer from 1986 to 1988.

Although no background ground water quality data are available, high levels of uranium, nitrate, and sulfate on the site suggest that uranium ore processing activities have contaminated ground water in the alluvium. Wells 702 and 704 are higher in uranium, nitrate, and manganese but lower in sulfate and selenium than are 705 and 708 . The highest concentration of selenium $(0.3$ to $0.8 \mathrm{mg} / \mathrm{L})$ is in ground water from monitor well 808 . Uranium and nitrate isopleth maps (Figures 3.2 and 3.3) indicate that the center of the plume appears to be near monitor wells 702 and 808 and is migrating to the northwest parallel to Brown's Wash.

The horizontal and vertical extent of contamination has not been determined in the alluvium because of incomplete well coverage downgradient from the site. However, surface water quality data at location 718 (Figure 3.1) in Brown's Wash downgradient from the site suggest that ground water from the alluvium or Upper Cedar Mountain Formation may be discharging to surface water. Even 
Table 3.2 Statistical summary of the Brown's Wash alluvium on-site ground water data, 1986 to 1988 , filtered samples, Green River, Utah, site

\begin{tabular}{|c|c|c|}
\hline Parameter & Above $\mathrm{DL}^{\mathrm{a}}$ & Range (mg/L) \\
\hline \multicolumn{3}{|l|}{ Inorganics } \\
\hline Aluminum & $12 / 17$ & $<0.1-0.4$ \\
\hline Ammonium & $18 / 20$ & $<0.1-42$ \\
\hline Antimony & $0 / 4$ & $<0.003$ \\
\hline Arsenic & $4 / 12$ & $<0.01-0.02$ \\
\hline Barium & $0 / 5$ & $<0.1$ \\
\hline Boron & $17 / 17$ & $0.23-0.7$ \\
\hline Cadmium & $1 / 4$ & $<0.001-0.072$ \\
\hline Calcium & $20 / 20$ & $366-531$ \\
\hline Chloride & $20 / 20$ & $76-480$ \\
\hline Chromium & $14 / 17$ & $<0.01-0.13$ \\
\hline Cobalt & $3 / 4$ & $<0.05-0.09$ \\
\hline Copper & $5 / 5$ & $0.01-0.04$ \\
\hline Fluoride & $20 / 20$ & $0.5-1.2$ \\
\hline Iron & $16 / 20$ & $<0.03-0.24$ \\
\hline Lead & $0 / 5$ & $<0.01$ \\
\hline Magnesium & $20 / 20$ & $120-320$ \\
\hline Manganese & $19 / 20$ & $<0.01-0.98$ \\
\hline Mercury & $0 / 5$ & $<0.0002$ \\
\hline Molybdenum & $14 / 20$ & $<0.01-0.27$ \\
\hline Nickel & $4 / 4$ & $0.05-0.10$ \\
\hline Nitrate & $20 / 20$ & $1.3-440$ \\
\hline Phosphate & $0 / 4$ & $<0.1$ \\
\hline Potassium & $20 / 20$ & $2.7-32$ \\
\hline Selenium & $13 / 20$ & $<0.002-0.50$ \\
\hline Silica & $4 / 4$ & $7-10$ \\
\hline Silver & $1 / 5$ & $<0.01-0.02$ \\
\hline Sodium & $20 / 20$ & $720-2540$ \\
\hline
\end{tabular}


Table 3.2 Statistical summary of the Brown's Wash alluvium on-site ground water data, 1986 to 1988, filtered samples, Green River, Utah, site (Concluded)

\begin{tabular}{lcc}
\hline \multicolumn{1}{c}{ Parameter } & Above $\mathrm{DL}^{\mathrm{a}}$ & Range (mg/L) \\
\hline Inorganics (continued) & & \\
Strontium & $4 / 4$ & $0.8-6.6$ \\
Sulfate & $20 / 20$ & $2560-6890$ \\
Sulfide & $0 / 1$ & $<0.1$ \\
Tin & $0 / 4$ & $<0.005$ \\
Uranium & $20 / 20$ & $0.007-1.96$ \\
Vanadium & $10 / 13$ & $<0.01-0.24$ \\
Zinc & $11 / 13$ & $<0.005-0.036$ \\
Radionuclides (pCi/L) & & (pCi/L) \\
Lead-210 & $3 / 3$ & $1.0-4.4$ \\
Polonium-210 & $3 / 3$ & $0.0-0.4$ \\
Radium-226 & $12 / 12$ & $0.0-0.5$ \\
Thorium-230 & $3 / 3$ & $0.0-3.1$ \\
\hline
\end{tabular}

${ }^{a} \mathrm{Above} \mathrm{DL}=$ number of samples with detectable quantity/total number of samples.

Note: Data are for Brown's Wash alluvium on-site wells 702, 704, 705, 708, and 808. $\mathrm{DL}$ - detection limit. 


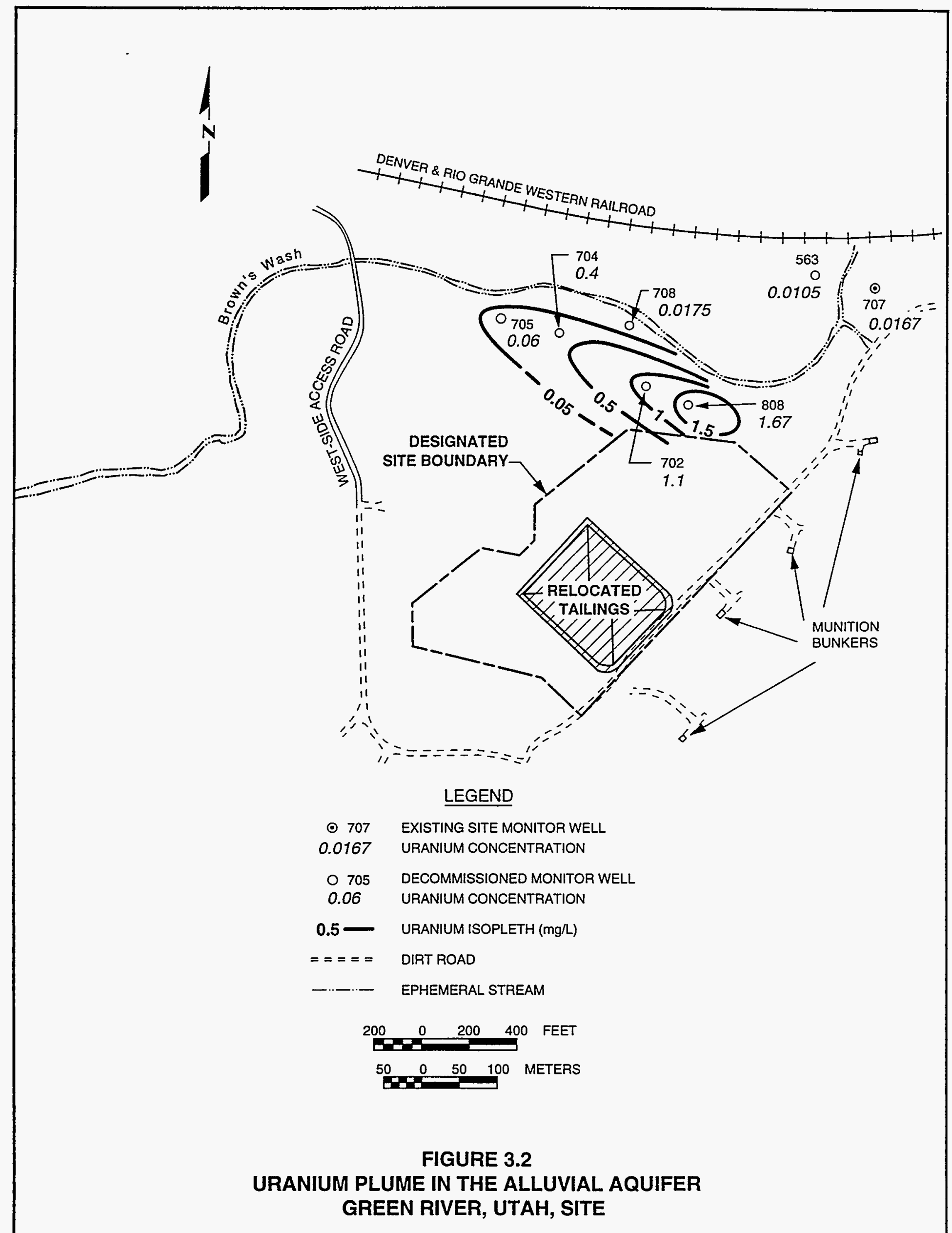




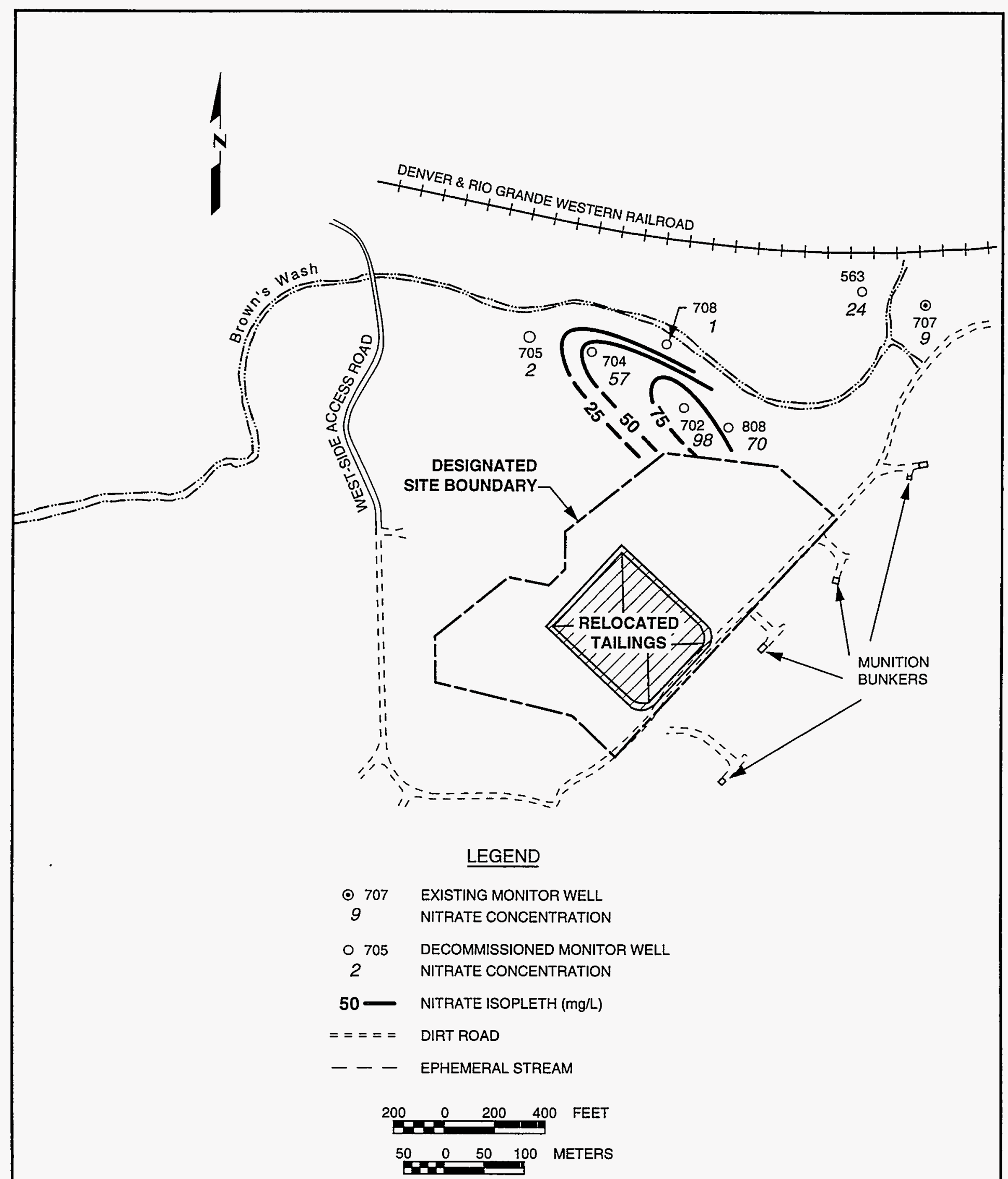

FIGURE 3.3

NITRATE PLUME IN THE ALLUVIAL AQUIFER GREEN RIVER, UTAH, SITE 
though dissolved constituents present in surface water at location 718 have most likely been concentrated through evaporation, the presence of high uranium, selenium, and nitrate concentrations in surface water samples provides evidence that discharge is occurring. If so, this location represents the farthest known extent of contamination from the processing site in the alluvial and/or Upper Cedar Mountain aquifers.

\subsubsection{Upper Cedar Mountain aquifer}

Because monitor well coverage was more complete in this aquifer than in the alluvium, the site was divided into two areas to assess contamination of the Upper Cedar Mountain aquifer. The first area (milling area) is upgradient of the former tailings pile and includes areas where milling operations took place. The second area (tailings area) is located adjacent to Brown's Wash in the vicinity of the abandoned tailings pile.

\section{Milling area}

Filtered ground water samples have been collected from this area from 1987 to 1994 (see Table 3.1 for sampling frequency and dates). High concentrations of nitrate in ground water from monitor wells 172 (32 to $83 \mathrm{mg} / \mathrm{L}), 176$ (120 to $290 \mathrm{mg} / \mathrm{L}), 179(59$ to $170 \mathrm{mg} / \mathrm{L})$, and 807 (300 to $1400 \mathrm{mg} / \mathrm{L})$ and uranium in ground water from monitor wells $172(0.001$ to $0.06 \mathrm{mg} / \mathrm{L}), 176(0.04$ to $0.07 \mathrm{mg} / \mathrm{L}), 179(0.1$ to $0.2 \mathrm{mg} / \mathrm{L})$, and $813(0.03$ to $0.06 \mathrm{mg} / \mathrm{L})$ suggest that the Upper Cedar Mountain Formation aquifer beneath and upgradient from the disposal cell may have been affected by the milling process. The contamination existed before the cell was constructed; therefore, the existing cell is not the source of this contamination. High nitrate in abandoned monitor wells 562 , 807 , and 816 and uranium in abandoned monitor wells 562 and 816 located beneath the cell (Figure 3.1) also support this assumption.

Affected ground water in the milling area appears to be more oxidizing than the surrounding ground water. For example, ground water from monitor wells 172 , 176 , and 179 is moderately oxidizing (approximately $+400 \mathrm{mV}$ as measured with a platinum probe) compared to adjoining monitor wells $171,173,174$, and $175(-300$ to $+200 \mathrm{mV}$ ). The correlation between contamination and oxidized ground water may suggest impact from oxidizing fluids, perhaps uranium mill tailings leachate.

\section{Tailings area}

Water quality was monitored in this region from 1986 to 1988 , before surface remediation began (see Table 3.1 for sampling frequency and dates).

Contamination in this region originates from the tailings themselves and possibly from milling operations conducted upgradient of the tailings disposal area.

The highest levels of contamination in the tailings area appear to be in the region of monitor wells 701, 703, and 581 (Figure 3.1), with contamination 
decreasing to the northwest in the direction of ground water flow. Ground water from monitor wells 701, 703, and 581 had high concentrations of uranium (up to $3.0 \mathrm{mg} / \mathrm{L}$ ), sulfate $(2400$ to $3600 \mathrm{mg} / \mathrm{L}$ ), molybdenum (up to $0.2 \mathrm{mg} / \mathrm{L}$ ), and nitrate (up to $2500 \mathrm{mg} / \mathrm{L}$ ), suggesting milling-related contamination. Concentrations of uranium, molybdenum, and nitrate decrease downgradient from the processing site in the region of monitor wells 583 and 585. However, sulfate concentrations are high off-site in the same region, suggesting that these concentrations may represent background variability, contamination from the milling process, or a combination of both.

Because of data discontinuities and possible disturbances created by surface cleanup activities in 1988 and 1989, only site data collected from 1986 to 1988 were used to construct the list of constituents elevated statistically above background levels. Preconstruction data were used to identify contaminants of potential concern because these are the only data available for two clearly contaminated areas: the tailings area and the processing area directly under the present-day disposal cell. It is assumed that any site-related contamination would have migrated into the ground water and reached one or more of the monitor wells in existence in 1988. Use of 1986-1988 background data for comparison to on-site data followed the statistical principle that comparisons should use concurrent data whenever possible. Exceptions to this principle had to be made for constituents not analyzed for in background water samples prior to 1989 (i.e., nickel, cobalt, and phosphate).

An initial screening of the 1986-1988 data indicated that the highest concentrations in the tailings area occurred in wells 701, 703, and occasionally in neighboring well 581. These three wells were selected to describe water quality under the tailings area. In the processing area, only four on-site wells existed prior to cell construction: 816, 562, 807, and 813. All showed concentrations above background for several constituents, and each well was higher than the others in at least one key constituent, so all four wells were selected to represent processing site water quality prior to surface cleanup. Table 3.3 summarizes background and on-site water quality data for the Upper Cedar Mountain unit.

Two statistical comparisons were made, each at the 0.025 level of significance. First, background levels from wells 806 and 811 were compared to pooled data from wells 701, 703, and 581 in the tailings area. Second, the background data were compared to pooled data from processing area wells $816,562,807$, and 813. Separate analyses for the tailings and processing areas were conducted because a different suite of contaminants could theoretically exist in the two areas, and pooling heterogeneous data could reduce the power of the statistical test. The use of the 0.025 level of significance was necessary to control the overall level of significance at 0.05 . The statistical method used was the Mann-Whitney.

More recently acquired 1989-1993 data were incorporated as follows. If a constituent was not determined to be above background levels based on 


\begin{tabular}{|c|c|c|c|c|c|c|c|}
\hline \multirow{12}{*}{ 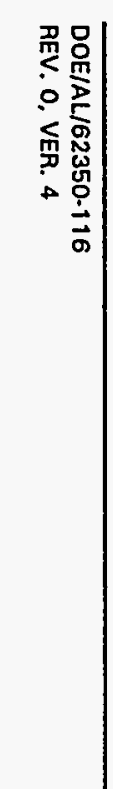 } & $\begin{array}{r}\text { Table } 3.3 \begin{array}{l}\text { Stati } \\
\text { sam }\end{array}\end{array}$ & $\begin{array}{l}\text { nmary of } g \\
\text { ept as note }\end{array}$ & $\begin{array}{l}\text { Id water qual } \\
\text { ireen River, }\end{array}$ & $\begin{array}{l}\text { Ita for th } \\
\text { site }\end{array}$ & Cedar Mou & $n$ aquifer (198 & 88 filtered \\
\hline & \multirow[b]{3}{*}{ Analyte } & \multicolumn{6}{|c|}{ Observed concentrations } \\
\hline & & \multicolumn{3}{|c|}{ Background $^{\mathbf{a}}$} & \multicolumn{3}{|c|}{ On-site ${ }^{b}$} \\
\hline & & Above $\mathrm{DL}^{\mathrm{C}}$ & Range & Median ${ }^{d}$ & Above $\mathrm{DL}^{\mathrm{C}}$ & Range & Mediand \\
\hline & \multicolumn{7}{|l|}{ Inorganics (mg/L) } \\
\hline & Aluminum $\mathrm{e}$ & $0 / 6$ & $<0.10$ & - & $19 / 26$ & $0.04-0.90$ & 0.20 \\
\hline & Ammonium $\mathrm{e}$ & $3 / 6$ & $<0.1-0.3$ & - & $21 / 28$ & $<0.1-51$ & 0.6 \\
\hline & Antimony & & Not sampled & & $0 / 5$ & $<0.003$ & - \\
\hline & Arsenic ${ }^{e, f}$ & $2 / 6$ & $0.005-0.007$ & - & $4 / 11$ & $<0.01-0.07$ & - \\
\hline & Barium & $2 / 2$ & $0.01-0.10$ & - & $9 / 10$ & $<0.01-0.20$ & 0.01 \\
\hline & Boron & $6 / 6$ & $0.70-0.89$ & 0.80 & $26 / 26$ & $0.30-0.90$ & 0.73 \\
\hline & Cadmium & $2 / 2$ & $0.025-0.026$ & - & $5 / 10$ & $<0.001-0.125$ & $<0.003$ \\
\hline$\omega$ & Calciume,f & $6 / 6$ & $4.1-5.2$ & 4.7 & $16 / 16$ & $366-560$ & 442 \\
\hline$\vec{\omega}$ & Chloride ${ }^{e, f}$ & $6 / 6$ & $150-200$ & 165 & $10 / 10$ & $920-1400$ & 1065 \\
\hline & Chromium & $2 / 6$ & $<0.01-0.07$ & - & $19 / 26$ & $<0.01-0.15$ & 0.02 \\
\hline & Cobalt ${ }^{9}$ & $0 / 2$ & $<0.05$ & - & $6 / 9$ & $<0.01-0.13$ & $<0.05$ \\
\hline & Copper & $0 / 2$ & $<0.01$ & - & $6 / 10$ & $<0.01-0.05$ & $<0.02$ \\
\hline & Fluoride & $6 / 6$ & $1.8-3.5$ & 2.2 & $28 / 28$ & $0.5-1.9$ & 1.0 \\
\hline & $\operatorname{Iron}^{e, f}$ & $3 / 6$ & $<0.01-0.30$ & - & $7 / 7$ & $0.14-2.47$ & 1.50 \\
\hline & Lead & $1 / 2$ & $<0.01-0.01$ & - & $5 / 10$ & $<0.01-0.09$ & $<0.02$ \\
\hline & Magnesium ${ }^{\mathrm{e}}$ & $6 / 6$ & $1.2-1.5$ & 1.4 & $28 / 28$ & $8.8-542$ & 131 \\
\hline & Manganese $^{e, f}$ & $4 / 6$ & $<0.01-0.02$ & 0.01 & $6 / 6$ & $1.23-2.20$ & 1.73 \\
\hline & Mercury & $0 / 2$ & $<0.0002$ & $\cdot$ & $3 / 10$ & $<0.0002-0.002$ & - \\
\hline & Molybdenum ${ }^{e}$ & $4 / 6$ & $<0.01-0.02$ & 0.02 & $22 / 28$ & $<0.01-0.22$ & $<0.10$ \\
\hline \multirow{3}{*}{ 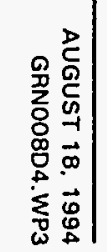 } & Nickel ${ }^{e, g}$ & $0 / 20$ & $<0.04$ & $\cdot$ & $7 / 9$ & $<0.01-0.09$ & 0.05 \\
\hline & Nitrate ${ }^{e, f}$ & $2 / 6$ & $<0.1-2.7$ & - & $6 / 6$ & $570-2480$ & 1245 \\
\hline & Phosphate ${ }^{g}$ & $0 / 2$ & $<0.1$ & - & $4 / 9$ & $<0.1-0.6$ & - \\
\hline
\end{tabular}




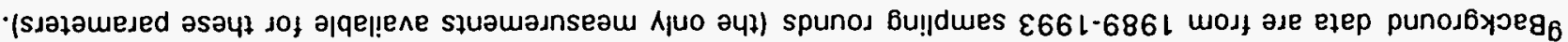

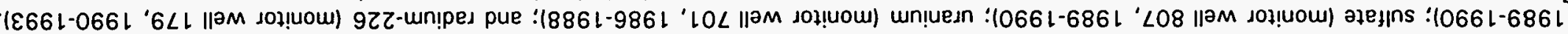

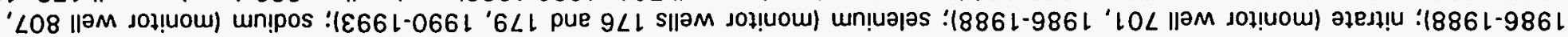

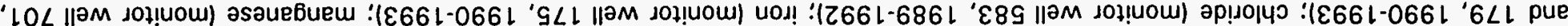

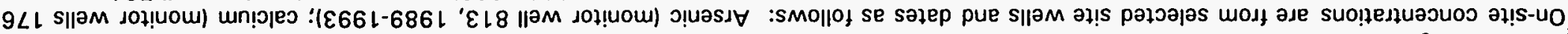

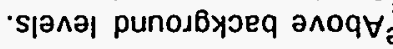
•əlqе!!ene әرе ejep

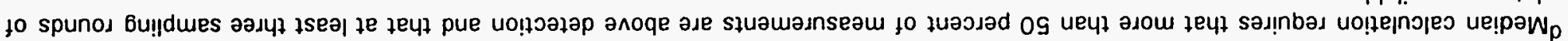

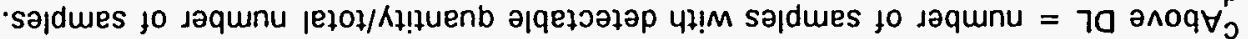

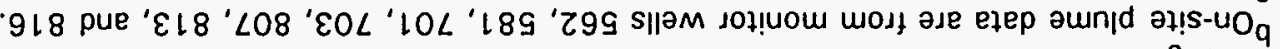

\begin{tabular}{|c|c|c|c|c|c|c|}
\hline- & $t^{\prime} 8 \cdot L^{\prime} l$ & $2 / 2$ & & pajdues loN & & 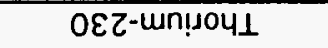 \\
\hline$\tau \cdot \varepsilon$ & $\tau \cdot \nabla \cdot 6 \cdot 0$ & $L / L$ & 10 & $\varepsilon \cdot 0-0 \cdot 0$ & $9 / 9$ & $\left.f^{‘}\right)^{9} 9 Z Z$-wn!pey \\
\hline - & $D^{\circ} L-0^{\circ} 0$ & $z / 2$ & & po|dues toN & & $0 เ z$-un!uolod \\
\hline \multirow[t]{2}{*}{-} & $\varepsilon L-G^{\circ} 0$ & $乙 / 乙$ & & pə|dues ION & & OLZ-peə7 \\
\hline & & & & & & $\left(7 / ! \partial^{d}\right)$ sep!|วnuo!pey \\
\hline $910^{\circ} 0$ & $890^{\circ} 0-900^{\circ} 0>$ & $Z Z / 12$ & - & $20 \cdot 0-900.0>$ & $9 / \varepsilon$ & әงu!z \\
\hline to.0 & $8 \varepsilon^{\circ} 0-10^{\circ} 0>$ & $Z Z / \triangleright l$ & - & $10.0>$ & $9 / 0$ & amn!peue \\
\hline $90 \cdot \tau$ & $\left\lfloor{ }^{\prime} \varepsilon-6 G^{\prime} \downarrow\right.$ & $9 / 9$ & - & $\varepsilon 00^{\circ} 0>$ & $\mathfrak{G} / \mathbf{l}$ & $f^{\prime} \partial^{\text {mnṇuesn }}$ \\
\hline- & $900^{\circ} 0>$ & $\mathrm{s} / 0$ & & pə|dues tON & & $u ! \perp$ \\
\hline- & $9 t-1 \cdot 0>$ & $G / L$ & - & $1 \cdot 0>$ & $2 / 0$ & әp!ฺns \\
\hline$O S t L$ & $096<-0899$ & $t / t$ & t09 & OLL-OSD & $9 / 9$ & $f^{\prime} \partial^{\text {əle } f \text { ns }}$ \\
\hline 0.2 & $8^{\circ} 01-8^{\circ} 0$ & $6 / 6$ & & pə|dues ION & & un!luods \\
\hline $098 \varepsilon$ & $080 t-0 t t \varepsilon$ & $t / t$ & 918 & $1 \angle 8-0 t \angle$ & $9 / 9$ & $f^{\prime 2} a^{\text {unnpos }}$ \\
\hline- & $10^{\circ} 0>$ & $9 / 0$ & - & $10.0>$ & $2 / 0$ & دәл!!S \\
\hline 0.8 & $8 L-t$ & $6 / 6$ & & pə|dues ION & & eग!!!S \\
\hline $9 \varepsilon^{\circ} 0$ & s9.0-sl.0 & $9 L / 9 L$ & $20^{\circ} 0$ & $8+0^{\circ} 0-900^{\circ} 0>$ & $9 / b$ & 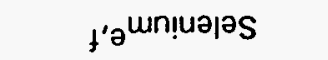 \\
\hline$\varepsilon^{\prime} L$ & $9 \cdot 62-6 \cdot 1$ & $82 / 82$ & $\nabla \cdot l$ & $9 \cdot\llcorner-\varepsilon \cdot \downarrow$ & $9 / 9$ & $\theta^{u n ! s s e t o d}$ \\
\hline \multirow[t]{2}{*}{$p^{\text {ue!pen }}$} & o6ugy & s70 ө^oq & $p^{\text {ue!pow }}$ & obuey & g70 8^oq & \multirow[t]{2}{*}{ 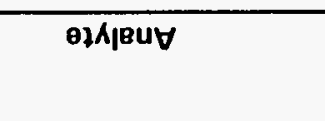 } \\
\hline & $q^{\theta} ! ! s-100$ & & & $e^{\text {punod6yjeg }}$ & & \\
\hline
\end{tabular}

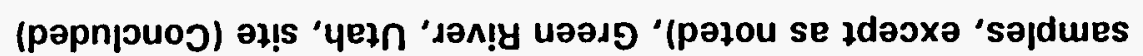

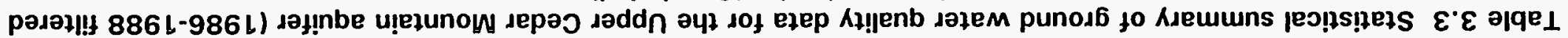


1986-1988 data, the recent data were screened to verify that more recent levels were consistent with the older data. For constituents elevated above background levels, the move recent data supplemented the older data, if the more recent levels observed in ground water from any monitor well exceeded those observed prior to surface cleanup. As a result, the evaluation of ground water contamination in the Upper Cedar Mountain aquifer is based on the well (or wells) with the highest observed concentrations, regardless of its location. In one sense this approach is conservative, as no single monitor well shows the highest concentration of all the constituents. Background and on-site water quality data for the Upper Cedar Mountain aquifer are summarized in Table 3.3. Constituents significantly above background levels in either location were identified and are noted in Table 3.3.

In summary, the extent of ground water contamination in both the Upper Cedar Mountain Formation and the Brown's Wash alluvium has not been fully characterized but appears to decrease down the predicted flow path. Furthermore, the ground water quality data, including elemental analysis redox and dissolved oxygen, suggest that constituents sensitive to the ambient reducing redox potential of ground water (i.e., uranium, molybdenum, arsenic, selenium, and nitrate) attenuate downgradient from the regions of maximum ground water contamination.

\subsection{CONTAMINANTS OF POTENTIAL CONCERN}

The data presented in Sections 3.1 and 3.2 were used to compile a list of contaminants that are of potential concern for the assessment of human health and environmental risks at the Green River site.

Since background ground water quality data are not available for the Brown's Wash alluvium, constituents that are highly elevated and clearly associated with the site are evaluated qualitatively as contaminants of potential concern. These include uranium, sulfate, and nitrate. Of site-related contaminants, these three contaminants at the observed concentrations also exhibit the greatest toxicity compared with other constituents present in alluvial ground water.

Constituents exceeding background levels in the Upper Cedar Mountain aquifer are shown in column 1 of Table 3.4. These constituents were screened for their potential to affect human health, using the criteria discussed below, to develop a final list of contaminants of potential concern for human health. Because ecological impacts differ from effects on human health, the complete list of contaminants are considered for ecological risk assessment in Section 7.0.

Several constituents that were above background levels were screened out because they are essential nutrients and because the levels at which they were detected are within nutritional ranges, even when added to expected dietary intake. These constituents are calcium, chloride, iron, potassium, and zinc. 
Table 3.4 Contaminants of potential concern for the Upper Cedar Mountain aquifer

\begin{tabular}{llll}
\hline $\begin{array}{l}\text { Contaminant levels } \\
\text { exceed background }\end{array}$ & $\begin{array}{c}\text { Contaminant levels } \\
\text { in nutritional range }\end{array}$ & $\begin{array}{c}\text { Contaminants at low } \\
\text { toxicity and/or high } \\
\text { dietary range }\end{array}$ & $\begin{array}{c}\text { Contaminants of } \\
\text { potential concern }\end{array}$ \\
\hline Aluminum & Calcium & Aluminum & Arsenic \\
Ammonium & Chloride & Ammonium & Manganese \\
Arsenic & Iron & Magnesium & Molybdenum \\
Calcium & Potassium & Nickel & Nitrate \\
Chloride & Zinc & & Radium-226 \\
Iron & & & Selenium \\
Magnesium & & & Sodium \\
Manganese & & & Sulfate \\
Molybdenum & & & Uranium \\
Nickel & & & Vanadium \\
Nitrate & & \\
Potassium & & \\
Radium-226 & & \\
Selenium & & \\
Sodium & & \\
Sulfate & & \\
Uranium & & \\
Vanadium & & \\
Zinc & & \\
\hline
\end{tabular}

aThe screening process starts with the first column; constituents listed in the second and third columns were subtracted from the list of constituents in the first column; the remaining constituents form the list shown in the last column. 
Aluminum, magnesium, and nickel were eliminated as contaminants of potential concern based on low toxicity and high normal dietary intake relative to observed levels. Although ammonium is not considered a dietary component, it is produced in the human body at levels that exceed $4000 \mathrm{mg} /$ day (Summerskill and Wolpert, 1970), roughly two orders of magnitude more than what would result from ingesting the most ammonium-contaminated water at the site $(51 \mathrm{mg} / \mathrm{L})$. Although these levels are substantially higher than background levels, they are not likely to be associated with adverse health effects. However, the detected concentrations of ammonium may affect the taste and odor of the water.

Uranium and radium-226 are the only radionuclides statistically (level of significance $<0.05$ ) above background levels in the Upper Cedar Mountain aquifer. It could not be determined whether longer-lived progeny of the uranium decay series other than radium-226 are above background levels because they have never been analyzed for in the background ground water. Thus, all of the longer-lived progeny of the uranium decay series are evaluated in Section 6.0.

After constituents were screened from the list based on the criteria described above, the remaining contaminants were arsenic, manganese, molybdenum, nitrate, selenium, sodium, sulfate, uranium, vanadium, and radium-226 (Table 3.4). These constituents form the basis of the risk assessment for the Upper Cedar Mountain aquifer at the Green River site.

\subsection{CONTAMINANT FATE AND TRANSPORT}

To predict the behavior of contaminants of concern in the aquifer, a hydrogeochemical analysis of contaminated ground water in the Upper Cedar Mountain Formation was performed. The analysis relied on geochemical modeling and observation of the spatial and temporal distribution of elements in ground water. Geochemical modeling using the computer codes MINTEQA2/PRODEFA2 (Allison et al., 1991), PHREEQE (Parkhurst et al., 1980), and WATEQF (Plummer et al., 1976) was used to determine 1) the species in which contaminants of potential concern are present in ground water beneath the site, and 2) the saturation indices, needed to determine which mineral phases are saturated with respect to solute in ground water and could therefore possibly remove constituents from the plume through precipitation. Aqueous species of contaminants of potential concern calculated through geochemical modeling are presented in Table 3.5 .

The behavior and the concentration of elements in ground water are influenced by the chemical and mechanical characteristics of the aquifer, including $\mathrm{pH}$ and redox, the mineralogy and chemical composition of the aquifer matrix (which partially controls sorption processes), hydrodynamic dispersion (resulting in dilution and mixing), and precipitation of solid phases. Of all the processes discussed above, hydrodynamic dispersion resulting in dilution is a ubiquitous phenomenon characteristic to all porous media. 
Table 3.5 Aqueous species of contaminants of potential concern in the Upper Cedar Mountain aquifer, Green River, Utah, site

\begin{tabular}{|c|c|c|c|c|}
\hline $\begin{array}{c}\text { Constituents } \\
\text { of concern }\end{array}$ & Common name & $\begin{array}{l}\text { Aqueous } \\
\text { species }^{\text {a }}\end{array}$ & $\begin{array}{c}\text { Valence } \\
\text { state }^{\mathbf{a}}\end{array}$ & $\begin{array}{c}\text { Molar } \\
\text { percent }\end{array}$ \\
\hline \multicolumn{5}{|c|}{ Inorganic constituents } \\
\hline \multirow[t]{2}{*}{ Arsenic } & Arsenate & $\mathrm{HAsO}_{4}{ }^{2-}$ & $A s(V)$ & 64 \\
\hline & Arsenate & $\mathrm{H}_{2} \mathrm{AsO}_{4}^{-}$ & $A s(V)$ & 36 \\
\hline \multirow[t]{3}{*}{ Manganese } & Manganese & $\mathrm{Mn}^{2+}$ & $M n(I I)$ & 67 \\
\hline & Manganese sulfate & $\mathrm{MnSO}_{4}{ }^{\mathrm{O}} \mathrm{AO}$ & $M n(I I)$ & 30 \\
\hline & Manganese bicarbonate & $\mathrm{MnHCO}_{3}+$ & $\mathrm{Mn}(\mathrm{II})$ & 3 \\
\hline Molybdenum & Molybdate & $\mathrm{MoO}_{4}{ }^{2-}$ & Mo(VI) & 100 \\
\hline Nitrate & Nitrate & $\mathrm{NO}_{3}^{-}$ & $N(V)$ & 100 \\
\hline \multirow[t]{2}{*}{ Selenium } & Selenite & $\mathrm{HSeO}_{3}^{-}$ & $\mathrm{Se}(I V)$ & 97 \\
\hline & Selenite & $\mathrm{SeO}_{3}{ }^{2-}$ & $\operatorname{Se}(I V)$ & 3 \\
\hline \multirow[t]{2}{*}{ Sodium } & Sodium & $\mathrm{Na}^{+}$ & $\mathrm{Na}(l)$ & 97 \\
\hline & Sodium sulfate & $\mathrm{NaSO}_{4}^{-}$ & $\mathrm{Na}(1)$ & 3 \\
\hline \multirow[t]{4}{*}{ Sulfate } & Sulfate & $\mathrm{SO}_{4}{ }^{2-}$ & $S(V I)$ & 71 \\
\hline & Calcium sulfate & $\mathrm{CaSO}_{4}{ }^{\mathrm{O}} \mathrm{AQ}$ & $S(V I)$ & 15 \\
\hline & Magnesium sulfate & $\mathrm{MgSO}_{4}{ }^{\mathrm{O}} \mathrm{AO}$ & $S(V I)$ & 9 \\
\hline & Sodium sulfate & $\mathrm{NaSO}_{4}^{-}$ & S(VI) & 5 \\
\hline \multirow[t]{4}{*}{ Uranium } & Uranyl tricarbonate & $\mathrm{UO}_{2}\left(\mathrm{CO}_{3}\right)_{3}^{4-}$ & U(VI) & 47 \\
\hline & Uranyl dicarbonate & $\mathrm{UO}_{2}\left(\mathrm{CO}_{3}\right)_{2}^{2-}$ & U(VI) & 42 \\
\hline & Uranyl diphosphate & $\mathrm{UO}_{2}\left(\mathrm{HPO}_{4}\right)_{2}$ & U(VI) & 9 \\
\hline & Uranyl carbonate & $\mathrm{UO}_{2} \mathrm{CO}_{3}{ }^{\mathrm{O}} \mathrm{AQ}$ & $\mathrm{U}(\mathrm{VI})$ & 2 \\
\hline \multirow[t]{4}{*}{ Vanadium } & Vanadate & $\mathrm{HV}_{2} \mathrm{O}_{7}^{3-}$ & $V(V)$ & 63 \\
\hline & Vanadate & $\mathrm{H}_{2} \mathrm{VO}_{4}^{-}$ & $V(V)$ & 33 \\
\hline & Vanadate & $\mathrm{HVO}_{4}{ }^{2-}$ & $V(V)$ & 3 \\
\hline & Vanadate & $\mathrm{H}_{2} \mathrm{~V}_{2} \mathrm{O}_{7}^{-}$ & $V(V)$ & 1 \\
\hline
\end{tabular}


Table 3.5 Aqueous species of contaminants of potential concern in the Upper Cedar Mountain aquifer, Green River, Utah, site (Concluded)

\begin{tabular}{|c|c|c|c|c|}
\hline $\begin{array}{c}\text { Constituents } \\
\text { of concern }\end{array}$ & Common name & $\begin{array}{l}\text { Aqueous } \\
\text { species }^{\text {a }}\end{array}$ & $\begin{array}{l}\text { Valence } \\
\text { state }^{\mathrm{a}}\end{array}$ & $\begin{array}{c}\text { Molar } \\
\text { percent }\end{array}$ \\
\hline \multicolumn{5}{|l|}{ Radionuclides } \\
\hline \multirow[t]{6}{*}{ Lead-210 } & Lead carbonate & $\mathrm{PbCO}_{3}{ }^{0} \mathrm{AO}$ & $\mathrm{Pb}(11)$ & 60 \\
\hline & Lead bicarbonate & $\mathrm{PbHCO}_{3}+$ & $\mathrm{Pb}(11)$ & 15 \\
\hline & Lead sulfate & $\mathrm{PbSO}_{4}{ }^{0} \mathrm{AO}$ & $\mathrm{Pb}(I I)$ & 12 \\
\hline & Lead ion & $\mathrm{Pb}^{2+}$ & $\mathrm{Pb}(\mathrm{II})$ & 9 \\
\hline & Lead disulfate & $\mathrm{Pb}\left(\mathrm{SO}_{4}\right)_{2}^{2-}$ & $\mathrm{Pb}(I I)$ & 2 \\
\hline & Lead nitrate & $\mathrm{PbNO}_{3}^{+}$ & $\mathrm{Pb}(I I)$ & 2 \\
\hline Polonium-210 & Polonium ion & $\mathrm{Po}^{2+}$ & Po(II) & 100 \\
\hline Radium-226 & Radium ion & $\mathrm{Ra}^{2+}$ & $\operatorname{Ra}(11)$ & 100 \\
\hline Thorium-230 & Thorium hydroxide & $\mathrm{Th}(\mathrm{OH})_{3}+$ & Th(IV) & Dominant \\
\hline
\end{tabular}

${ }^{a}$ Ground water analysis (1988) from monitor well 701 along with maximum concentrations of contaminants of potential concern (Table 3.3) were used as input for the model. Redox information was taken from Brookins, 1988. 


\section{Arsenic}

Arsenic is present in ground water in both the alluvial system and the Upper Cedar Mountain aquifer (Tables 3.2 and 3.3). Arsenic is moderately mobile in an oxidizing aqueous environment as arsenate species (Table 3.5), but generally the mobility increases as the oxidation state of arsenic decreases. Arsenite As(III) has a greater solubility with respect to solid mineral phases, and aqueous species generally sorb to the aquifer matrix less readily than As(V) species. Because background ground water in the Upper Cedar Mountain Formation is more reducing than ground water in the region of the plume, arsenic may be more mobile in the far field environment. However, low concentrations of arsenic in ground water downgradient from the processing site suggest arsenic is removed from the plume along the flow path through geochemical mechanisms and hydrodynamic dispersion.

\section{Manganese}

The mobility of manganese is primarily controlled by the redox state of the aquifer. Manganese is present in ground water in the $\mathrm{Mn}(I I)$ valence state, predominant as $\mathrm{Mn}^{2+}$ and complexed with sulfate and bicarbonate (Table 3.5). The ground water is saturated with respect to the mineral phase $\mathrm{MnHPO}_{4}$, and this mineral may be responsible for removing a portion of manganese from the plume. Additional removal of manganese through sorption and coprecipitation with iron phases may also be occurring downgradient from the mill site. Concentrations of manganese in ground water decrease downgradient from the processing site, indicating that some attenuation or hydrodynamic dispersion is taking place.

\section{Molybdenum}

Molybdenum is present in ground water in the site vicinity predominantly as the Mo(VI) molybdate species (Table 3.5). Molybdate is relatively mobile under moderately oxidizing conditions at a pH above 8 . However, ground water from monitor wells 584 and 815 , at distant downgradient locations, shows decreased concentrations of molybdenum (at or slightly above the detection limit), suggesting that somehow molybdenum is attenuated from the plume as it travels downgradient from the processing site. Physicochemical processes and hydrodynamic dispersion are probably responsible for the downgradient decreases in concentrations.

\section{Nitrate}

Nitrogen contamination is present predominantly as nitrate, with lesser amounts of ammonium in ground water beneath the site (Table 3.3). The only nitrogen complex used in the milling process was ammonia, which was used to adjust the $\mathrm{pH}$ at the end of the acid leach circuit. During the process, ammonia reacted with acids, forming ammonium that was then biologically oxidized to nitrate in the tailings pile and in ground water beneath the site. The nitrate 
plume in the alluvial system, shown in Figure 3.3, is currently moving northwest parallel to Brown's Wash. Nitrate is present as the N(V) nitrate ion (Table 3.5). The predominant mechanism responsible for attenuating nitrate in ground water is most likely denitrifying reactions occurring under suboxic conditions (less than $1 \mathrm{mg} / \mathrm{L}$ of dissolved oxygen [DO]), which exist in ground water downgradient from the processing site. Nitrate concentrations in ground water decrease from approximately $1700 \mathrm{mg} / \mathrm{L}$ in monitor well 701 to below the detection limit in monitor well 581 and to approximately $1 \mathrm{mg} / \mathrm{L}$ in ground water from monitor well 584 (1988 water quality data). This decrease in concentration suggests that nitrate is probably biologically transformed into molecular nitrogen in the aquifer along the ground water flow path. This is probably the case, because there is very little sorption of nitrate onto the aquifer matrix and there are no nitrate solid mineral phases that are saturated with respect to ground water in the vicinity of the processing site. Hydrodynamic dispersion may also reduce concentrations of nitrate along the flow path.

\section{Selenium}

Selenium is associated with uranium ore and is mobilized, along with uranium, during the acid leach portion of the milling process. Selenium as selenite, $\mathrm{Se}(\mathrm{IV})$, is the predominant species in the center of the plume near monitor well 701 (Table 3.5). In reducing ground water downgradient from the plume, the mineral phases ferroselite and native selenium are oversaturated, suggesting the precipitation of these minerals may attenuate selenium. Analysis of ground water downgradient from the plume (monitor wells 583,584, and 585) shows decreasing selenium concentrations, suggesting that in addition to hydrodynamic dispersion, reducing conditions may be removing selenium (probably as native selenium) from contaminated ground water along the flow path.

\section{Sodium}

The addition of sodium chlorate as an oxidizing agent, dissolution of sodium minerals during the acid leach circuit, and cation exchange with calcium and magnesium in clays are responsible for the elevated concentration of sodium in ground water in the vicinity of the processing site. Sodium is present in ground water predominately as a cation, $\mathrm{Na}(\mathrm{l})$ (Table 3.5 ). The primary mechanism of sodium attenuation is most likely cation exchange with clay minerals, but sodium acts as a somewhat conservative cation if calcium or other divalent alkali earth elements are present in elevated concentrations within the system. Therefore, if divalent cations saturate clay exchange sites, sodium is expected to persist in ground water downgradient from the former mill site. Hydrodynamic dispersion may also affect the concentration of sodium down the flow path. 


\section{Sulfate}

High concentrations of sulfate in ground water in the vicinity of the processing site are due to the addition of $\mathrm{H}_{2} \mathrm{SO}_{4}$ during the milling process and the oxidation of sulfide minerals. Sulfate is present in ground water predominantly as a $\mathrm{SO}_{4}{ }^{2-}$ ion or is complexed with calcium, magnesium, or sodium (Table 3.5). The ground water is saturated with respect to the mineral phase of gypsum in both the alluvial system and the Upper Cedar Mountain Formation beneath the site. Therefore, precipitation of gypsum will most likely serve as a mechanism to remove some sulfate from ground water. Ground water from monitor wells downgradient from monitor well 701 is not saturated with respect to gypsum and shows both a decrease (monitor well 581) and an increase (monitor well 584) in sulfate. This may be due to 1) the natural variability of ground water chemistry in the Cedar Mountain Formation, 2) the general conservative nature of the sulfate ion in ground water downgradient from the site, and 3) the heterogeneity of the Upper Cedar Mountain Formation aquifer matrix. As the plume migrates into the far-field environment, hydrodynamic dispersion effects will most likely be responsible for decreasing sulfate concentrations along the ground water flow path.

\section{Uranium}

Uranium is present in ground water in the vicinity of the processing site as a residual product of the milling process. Uranium is present in the plume predominantly as U(VI), uranyl tricarbonate and dicarbonate complexes (Table 3.5). These species are mobile under moderately oxidizing ground water with neutral $\mathrm{pH}$, conditions characteristic of the plume. However, background and downgradient ground water is moderately to strongly reducing $(+200$ to $-400 \mathrm{mV}$ ), an environment where uranium may be present as U(IV). Geochemical modeling predicts that under these conditions, U(IV) is relatively immobile, and the mineral phases uraninite, amorphous $\cup_{2}, U_{4} \mathrm{O}_{9}$, ningyoite, and uramphite are thermodynamically oversaturated with respect to ground water. Precipitation of these mineral phases, sorption onto the aquifer matrix, and hydrodynamic dispersion are most likely responsible for removing and diluting uranium downgradient from the former mill site.

\section{$\underline{\text { Vanadium }}$}

Vanadium is associated with uranium mineralization and was liberated along with uranium in the leach process. Therefore, the presence of vanadium in ground water beneath the processing site indicates impact by milling activities. Vanadium is present in contaminated ground water predominantly as vanadate, $V(V)$, forming oxyanion complexes (Table 3.5). Vanadium in the V(V) oxidation state sorbs strongly with iron oxyhydroxides (Rai and Zachara, 1984), which are thermodynamically oversaturated in ground water beneath the processing site. Sodium, calcium, and magnesium vanadate minerals are thermodynamically oversaturated, as are carnotite, lead vanadate, tyuyamunite and iron vanadate. Therefore, the precipitation of these minerals and sorption onto the aquifer 
matrix attenuates vanadium from the contaminant plume down the ground water flow path. These mechanisms and hydrodynamic dispersion explain the low concentration (at or slightly above the detection limit) of vanadium in ground water (monitor wells 583, 584, and 585) downgradient from the processing site.

\section{Radionuclides}

Uranium and radium-226 are the only radionuclides statistically (level of significance $<0.05$ ) above background levels in the Upper Cedar Mountain aquifer. Other uranium decay products have never been analyzed for in the background ground water. However, since uranium decays to radioactive progeny, the other longer-lived progeny of the uranium decay series (represented by lead-210, polonium-210, and thorium-230) are also discussed here.

Lead-210, polonium-210, radium-226, and thorium-230 are residual decay products of uranium. They were mobilized along with uranium in the acid circuit of the milling process. Geochemical modeling predicts that lead forms complexes with carbonate and sulfate, that polonium and radium are present as uncomplexed cations, and that thorium is present as hydroxyl species (Table 3.5). All four radionuclides form low-solubility mineral phases and are present in the center of the plume (monitor well 701) at very low concentrations. Ground water downgradient from monitor well 701 contains concentrations of the four radionuclides at or slightly above the detection limit (monitor wells 581, 583, and 585) and at or below the detection limit (monitor well 584). This suggests that lead-210, polonium-210, radium-226, and thorium-230 attenuate from ground water downgradient from the processing site. Hydrodynamic dispersion may also be responsible for diluting radionuclides down the ground water flow path.

\subsection{SURFACE WATER MONITORING}

Filtered ground water samples were collected from 1986 until 1992 from two surface sampling locations upstream (location 801) and downstream (location 802) from Brown's Wash on the east bank of the Green River. Sampling locations for the Green River are shown in Figure 3.1.

Natural water quality of the Green River is dominated by sulfate, calcium, and. sodium, with concentrations of trace elements at or slightly above the detection limit. The $\mathrm{pH}$ is above 8 , similar to that of ground water in the vicinity of the processing site, and the TDS ranges approximately from 430 to $750 \mathrm{mg} / \mathrm{L}$. A statistical summary of water quality data is presented in Table 3.6.

Water quality analyses from locations 801 and 802 indicate that the impact of milling activities on water quality of the Green River is undetectable.

Surface water and sediment were sampled at five locations along Brown's Wash from 1982 through 1993 (Table 3.1 and Figure 3.1). The highest levels of 
Table 3.6 Statistical summary of surface water quality data for the Green River, 1986 1992 filtered samples, Green River, Utah, site

\begin{tabular}{|c|c|c|c|c|c|}
\hline Parameter & Location & $\begin{array}{c}\text { Number of } \\
\text { samples }\end{array}$ & Minimum & Median & Maximum \\
\hline Aluminum & $\begin{array}{l}801 \\
802\end{array}$ & $\begin{array}{l}8 \\
6\end{array}$ & $\begin{array}{r}<0.01 \\
0.05\end{array}$ & $\begin{array}{l}0.10 \\
0.10\end{array}$ & $\begin{array}{l}0.42 \\
0.20\end{array}$ \\
\hline Ammonium & $\begin{array}{l}801 \\
802\end{array}$ & $\begin{array}{l}15 \\
15\end{array}$ & $\begin{array}{l}0.01 \\
0.03\end{array}$ & $\begin{array}{l}a \\
a\end{array}$ & $\begin{array}{l}0.20 \\
0.20\end{array}$ \\
\hline Antimony & $\begin{array}{l}801 \\
802\end{array}$ & $\begin{array}{l}2 \\
1\end{array}$ & $\begin{array}{l}<0.003 \\
<0.003\end{array}$ & $\begin{array}{l}a \\
a\end{array}$ & $\begin{array}{c}0.8 \\
<0.003\end{array}$ \\
\hline Arsenic & $\begin{array}{l}801 \\
802\end{array}$ & $\begin{array}{l}15 \\
15\end{array}$ & $\begin{array}{l}<0.002 \\
<0.002\end{array}$ & $\begin{array}{l}a \\
a\end{array}$ & $\begin{array}{l}0.004 \\
0.003\end{array}$ \\
\hline Barium & $\begin{array}{l}801 \\
802\end{array}$ & $\begin{array}{l}4 \\
2\end{array}$ & $\begin{array}{l}0.08 \\
0.08\end{array}$ & $\begin{array}{l}0.12 \\
0.14\end{array}$ & $\begin{array}{l}0.20 \\
0.20\end{array}$ \\
\hline Boron & $\begin{array}{l}801 \\
802\end{array}$ & $\begin{array}{l}7 \\
5\end{array}$ & $\begin{array}{l}0.05 \\
0.10\end{array}$ & $\begin{array}{l}0.19 \\
0.20\end{array}$ & $\begin{array}{l}0.20 \\
0.21\end{array}$ \\
\hline Cadmium & $\begin{array}{l}801 \\
802\end{array}$ & $\begin{array}{l}14 \\
12\end{array}$ & $\begin{array}{l}<0.001 \\
<0.001\end{array}$ & $\begin{array}{l}a \\
a\end{array}$ & $\begin{array}{l}0.002 \\
0.002\end{array}$ \\
\hline Calcium & $\begin{array}{l}801 \\
802\end{array}$ & $\begin{array}{l}19 \\
15\end{array}$ & $\begin{array}{l}34 \\
53\end{array}$ & $\begin{array}{l}68 \\
70\end{array}$ & $\begin{array}{l}80 \\
79\end{array}$ \\
\hline Chloride & $\begin{array}{l}801 \\
802\end{array}$ & $\begin{array}{l}19 \\
15\end{array}$ & $\begin{array}{r}7 \\
21\end{array}$ & $\begin{array}{l}25 \\
25\end{array}$ & $\begin{array}{l}36 \\
38\end{array}$ \\
\hline Chromium & $\begin{array}{l}801 \\
802\end{array}$ & $\begin{array}{l}17 \\
15\end{array}$ & $\begin{array}{l}<0.001 \\
<0.008\end{array}$ & $\begin{array}{l}\mathrm{a} \\
\mathrm{a}\end{array}$ & $\begin{array}{l}0.07 \\
0.03\end{array}$ \\
\hline Cobalt & $\begin{array}{l}801 \\
802\end{array}$ & $\begin{array}{l}4 \\
2\end{array}$ & $\begin{array}{l}<0.003 \\
<0.05\end{array}$ & $\begin{array}{l}a \\
a\end{array}$ & $\begin{array}{l}<0.05 \\
<0.05\end{array}$ \\
\hline Copper & $\begin{array}{l}801 \\
802\end{array}$ & $\begin{array}{l}5 \\
3\end{array}$ & $\begin{array}{l}0.003 \\
<0.01\end{array}$ & $\begin{array}{l}0.01 \\
a\end{array}$ & $\begin{array}{l}0.03 \\
0.03\end{array}$ \\
\hline Fluoride & $\begin{array}{l}801 \\
802\end{array}$ & $\begin{array}{l}9 \\
5\end{array}$ & $\begin{array}{l}0.1 \\
0.2\end{array}$ & $\begin{array}{l}0.3 \\
0.3\end{array}$ & $\begin{array}{l}0.5 \\
0.5\end{array}$ \\
\hline Iron & $\begin{array}{l}801 \\
802\end{array}$ & $\begin{array}{l}17 \\
15\end{array}$ & $\begin{array}{c}<0.003 \\
0.02\end{array}$ & $\begin{array}{l}a \\
a\end{array}$ & $\begin{array}{l}0.35 \\
0.13\end{array}$ \\
\hline Lead & $\begin{array}{l}801 \\
802\end{array}$ & $\begin{array}{l}13 \\
11\end{array}$ & $\begin{array}{l}<0.001 \\
<0.002\end{array}$ & $\begin{array}{l}\mathrm{a} \\
\mathrm{a}\end{array}$ & $\begin{array}{l}<0.03 \\
<0.03\end{array}$ \\
\hline Magnesium & $\begin{array}{l}801 \\
802\end{array}$ & $\begin{array}{l}19 \\
15\end{array}$ & $\begin{array}{l}14 \\
21\end{array}$ & $\begin{array}{l}32 \\
33\end{array}$ & $\begin{array}{l}39 \\
39\end{array}$ \\
\hline Manganese & $\begin{array}{l}801 \\
802\end{array}$ & $\begin{array}{l}7 \\
5\end{array}$ & $\begin{array}{l}<0.001 \\
<0.01\end{array}$ & $\begin{array}{l}0.01 \\
0.01\end{array}$ & $\begin{array}{l}0.02 \\
0.02\end{array}$ \\
\hline
\end{tabular}


Table 3.6 Statistical summary of surface water quality data for the Green River, 1986-1992 filtered samples, Green River, Utah, site (Continued)

\begin{tabular}{|c|c|c|c|c|c|}
\hline Parameter & Location & $\begin{array}{l}\text { Number of } \\
\text { samples }\end{array}$ & Minimum & Median & Maximum \\
\hline Mercury & $\begin{array}{l}801 \\
802\end{array}$ & $\begin{array}{l}4 \\
2\end{array}$ & $\begin{array}{l}<0.0001 \\
<0.0002\end{array}$ & $\begin{array}{l}a \\
a\end{array}$ & $\begin{array}{l}<0.0001 \\
<0.0002\end{array}$ \\
\hline Molybdenum & $\begin{array}{l}801 \\
802\end{array}$ & $\begin{array}{l}17 \\
15\end{array}$ & $\begin{array}{l}<0.005 \\
<0.005\end{array}$ & $\begin{array}{l}a \\
a\end{array}$ & $\begin{array}{l}0.18 \\
0.18\end{array}$ \\
\hline Nickel & $\begin{array}{l}801 \\
802\end{array}$ & $\begin{array}{l}13 \\
11\end{array}$ & $\begin{array}{r}<0.001 \\
0.007\end{array}$ & $\begin{array}{l}a \\
a\end{array}$ & $\begin{array}{l}<0.04 \\
<0.04\end{array}$ \\
\hline Nitrate & $\begin{array}{l}801 \\
802\end{array}$ & $\begin{array}{l}15 \\
15\end{array}$ & $\begin{array}{l}<0.1 \\
<0.1\end{array}$ & $\begin{array}{l}1.9 \\
1.8\end{array}$ & $\begin{array}{r}9.2 \\
12.4\end{array}$ \\
\hline Phosphate & $\begin{array}{l}801 \\
802\end{array}$ & $\begin{array}{l}2 \\
2\end{array}$ & $\begin{array}{l}<0.1 \\
<0.1\end{array}$ & $\begin{array}{l}a \\
a\end{array}$ & $\begin{array}{l}1.5 \\
6.5\end{array}$ \\
\hline Potassium & $\begin{array}{l}801 \\
802\end{array}$ & $\begin{array}{l}19 \\
15\end{array}$ & $\begin{array}{l}1.4 \\
2.3\end{array}$ & $\begin{array}{l}2.7 \\
2.8\end{array}$ & $\begin{array}{l}4.1 \\
4.1\end{array}$ \\
\hline Selenium & $\begin{array}{l}801 \\
802\end{array}$ & $\begin{array}{l}17 \\
15\end{array}$ & $\begin{array}{l}<0.002 \\
<0.002\end{array}$ & $\begin{array}{l}a \\
a\end{array}$ & $\begin{array}{l}0.006 \\
0.006\end{array}$ \\
\hline Silica $\left(\mathrm{SiO}_{2}\right)$ & $\begin{array}{l}801 \\
802\end{array}$ & $\begin{array}{l}5 \\
1\end{array}$ & $\begin{array}{l}4.0 \\
4.0\end{array}$ & $\begin{array}{l}8.8 \\
a\end{array}$ & $\begin{array}{l}9.4 \\
4.0\end{array}$ \\
\hline Silver & $\begin{array}{l}801 \\
802\end{array}$ & $\begin{array}{l}4 \\
2\end{array}$ & $\begin{array}{l}<0.001 \\
<0.01\end{array}$ & $\begin{array}{l}\mathrm{a} \\
\mathrm{a}\end{array}$ & $\begin{array}{l}<0.01 \\
<0.01\end{array}$ \\
\hline Sodium & $\begin{array}{l}801 \\
802\end{array}$ & $\begin{array}{l}19 \\
15\end{array}$ & $\begin{array}{l}22 \\
48\end{array}$ & $\begin{array}{l}77 \\
85\end{array}$ & $\begin{array}{l}100 \\
106\end{array}$ \\
\hline Strontium & $\begin{array}{l}801 \\
802\end{array}$ & $\begin{array}{l}2 \\
1\end{array}$ & $\begin{array}{l}0.8 \\
1.0\end{array}$ & $\begin{array}{l}a \\
a\end{array}$ & $\begin{array}{l}1.0 \\
1.0\end{array}$ \\
\hline Sulfate & $\begin{array}{l}801 \\
802\end{array}$ & $\begin{array}{l}19 \\
15\end{array}$ & $\begin{array}{r}79 \\
160\end{array}$ & $\begin{array}{l}255 \\
257\end{array}$ & $\begin{array}{l}330 \\
316\end{array}$ \\
\hline Sulfide & $\begin{array}{l}801 \\
802\end{array}$ & $\begin{array}{l}1 \\
1\end{array}$ & $\begin{array}{l}<0.1 \\
<0.1\end{array}$ & $\begin{array}{l}a \\
a\end{array}$ & $\begin{array}{l}<0.1 \\
<0.1\end{array}$ \\
\hline Tin & $\begin{array}{l}801 \\
802\end{array}$ & $\begin{array}{l}1 \\
1\end{array}$ & $\begin{array}{l}<0.005 \\
<0.005\end{array}$ & $\begin{array}{l}\mathrm{a} \\
\mathrm{a}\end{array}$ & $\begin{array}{l}<0.005 \\
<0.005\end{array}$ \\
\hline Uranium & $\begin{array}{l}801 \\
802\end{array}$ & $\begin{array}{l}15 \\
15\end{array}$ & $\begin{array}{l}<0.001 \\
<0.001\end{array}$ & $\begin{array}{l}0.004 \\
0.003\end{array}$ & $\begin{array}{l}0.007 \\
0.006\end{array}$ \\
\hline Vanadium & $\begin{array}{l}801 \\
802\end{array}$ & $\begin{array}{l}16 \\
14\end{array}$ & $\begin{array}{r}<0.005 \\
0.007\end{array}$ & $\begin{array}{l}a \\
0.01\end{array}$ & $\begin{array}{l}0.24 \\
0.25\end{array}$ \\
\hline Zinc & $\begin{array}{l}801 \\
802\end{array}$ & $\begin{array}{l}7 \\
5\end{array}$ & $\begin{array}{l}<0.005 \\
<0.005\end{array}$ & $\begin{array}{l}0.008 \\
a\end{array}$ & $\begin{array}{l}0.20 \\
0.04\end{array}$ \\
\hline
\end{tabular}


Table 3.6 Statistical summary of surface water quality data for the Green River, 1986-1992 filtered samples, Green River, Utah, site (Concluded)

\begin{tabular}{cccccc}
\hline Parameter & Location & $\begin{array}{c}\text { Number of } \\
\text { samples }\end{array}$ & Minimum & Median & Maximum \\
\hline Radium-226 $^{\mathrm{b}}$ & 801 & 14 & 0.0 & 0.1 & 0.2 \\
& 802 & 14 & 0.0 & 0.1 & 0.2 \\
Thorium-230 $^{\mathrm{b}}$ & 801 & 1 & 1.0 & $\mathrm{a}$ & 1.0 \\
& 802 & 1 & 0.8 & $\mathrm{a}$ & 0.8 \\
\hline
\end{tabular}

a Median calculation requires that more than 50 percent of measurements are above DLs and that at least three sampling rounds of data are available.

${ }^{b}$ Concentration as activity in picocuries per liter.

Notes: 1. All concentrations are in milligrams per liter unless specified.

2. Location 801 is upstream and location 802 downstream from the confluence of Brown's Wash and the Green River. 
contamination in Brown's Wash occurred at standing water location 718 downstream from the former uranium processing site: nitrate $(1200 \mathrm{mg} / \mathrm{L})$, sulfate $(7000 \mathrm{mg} / \mathrm{L})$, and uranium $(1.9 \mathrm{mg} / \mathrm{L})$. It appears that this water may originate from the alluvial or the Upper Cedar Mountain aquifers. A comprehensive evaluation of surface water and sediment contamination along Brown's Wash is provided in Section 7.3.1. 


\subsection{EXPOSURE ASSESSMENT}

Two water-bearing units at the Green River former uranium processing site are of concern for this risk assessment: the Brown's Wash alluvium and the Upper Cedar Mountain aquifer. Background water quality in the Brown's Wash alluvium before milling activities occurred has not been quantified; therefore, it is impossible to determine which constituents present at elevated concentrations are a result of milling operations. Because of this, human exposures from ingesting contaminated Brown's Wash alluvium ground water could not be evaluated comprehensively. As discussed in Section 3.3, only exposures to nitrate, sulfate, and uranium through ingestion of drinking water are evaluated qualitatively in Section 6.0. This qualitative evaluation is based on maximum observed concentrations presented in Table 3.2. This section discusses and quantifies the potential exposures that could be incurred by future residents or by others who use the Upper Cedar Mountain aquifer ground water contaminated by the former Green River processing site.

\subsection{POTENTIALLY EXPOSED POPULATION}

Exposure can occur only if there are both a source of contamination and a mechanism of transport to a receptor population or an individual. Ground water contaminated by uranium processing at the Green River site is not currently used by area residents.

Contaminated ground water seeps to the surface near the site. This surface expression occurs in Brown's Wash. Livestock could potentially drink the contaminated ground water when it recharges Brown's Wash. In the future, livestock could be watered with ground water from the alluvial and/or Upper Ceder Mountain aquifer. Using these livestock for food would create an exposure pathway to humans. Plants with roots in the alluvial aquifer or irrigated with water from this unit or the Upper Cedar Mountain aquifer could take up and concentrate contaminants, forming a pathway to humans through plant consumption. Finally, in the future, a domestic well could be drilled or hand-dug in the Upper Cedar Mountain aquifer, creating an exposure pathway through drinking and bathing.

Since there are no current human receptors of contaminated ground water, a future ground water use scenario is assumed. This scenario evaluates domestic use of contaminated ground water consistent with current water use by the population in the region. The potentially exposed population consists of the following age groups: infants (birth to 1 year old), children ( 1 to 10 years old), and adults ( 11 to 65 years old). These age groups were selected for the following reasons:

- Survey data for population variables such as age, weight, and daily water intake are available for these age groups. 
- Toxicological variables are similar within these age groups, including responsiveness of sensitive subgroups (infants and children) to the contaminants of potential concern, toxicant intake-to-body-weight ratios, and toxicokinetics.

Water in the region is used primarily for household purposes such as drinking, cooking, and bathing. Other uses typical of the region that could indirectly lead to human exposure include irrigation and livestock watering. Although it is unlikely that the Upper Cedar Mountain ground water will be used in the future for household purposes because of its naturally poor quality and the existing public water supply system, this risk assessment will assume hypothetical future use of the Upper Cedar Mountain aquifer ground water for drinking, cooking, and bathing. Two pathways other than drinking water ingestion (irrigation and livestock watering with contaminated Upper Cedar Mountain ground water) are also evaluated. Figure 4.1 provides a conceptual model for potential ground water exposure pathways that could result from these uses.

\subsubsection{Drinking water ingestion}

Drinking water ingestion is generally the most significant exposure route for ground water contaminated with metals and other nonvolatile compounds. For this evaluation, drinking water consumption includes amounts of water consumed for drinking, as well as amounts of water used for food preparation (e.g., reconstituted juices, soup, rice, and beans). To compare the relative significance of the drinking water ingestion exposure route, a screening level assessment of drinking water intake is shown in Table 4.1. These calculations are based on conservative estimates of contaminant concentration (i.e., the estimated 95 th percentile of the simulated distributions described in Section 4.3) using data from the most contaminated wells screened in the Upper Cedar Mountain aquifer.

\subsubsection{Dermal absorption}

Dermal absorption is the process by which chemicals coming into contact with the skin become absorbed into the blood vessels near the surface of the skin. Although some compounds are absorbed easily in this manner, metals are poorly absorbed through intact skin.

To evaluate this exposure route, a screening calculation was performed to determine whether the exposure contribution from dermal absorption would be significant compared to the drinking water route for the contaminants of potential concern. Since chemical-specific absorption factors are not available for these contaminants, it was assumed that they are absorbed across the skin at the same rate as water. This assumption is likely to overestimate any potential exposure contribution from dermal absorption. The results of the screening are shown in Table 4.1 . 


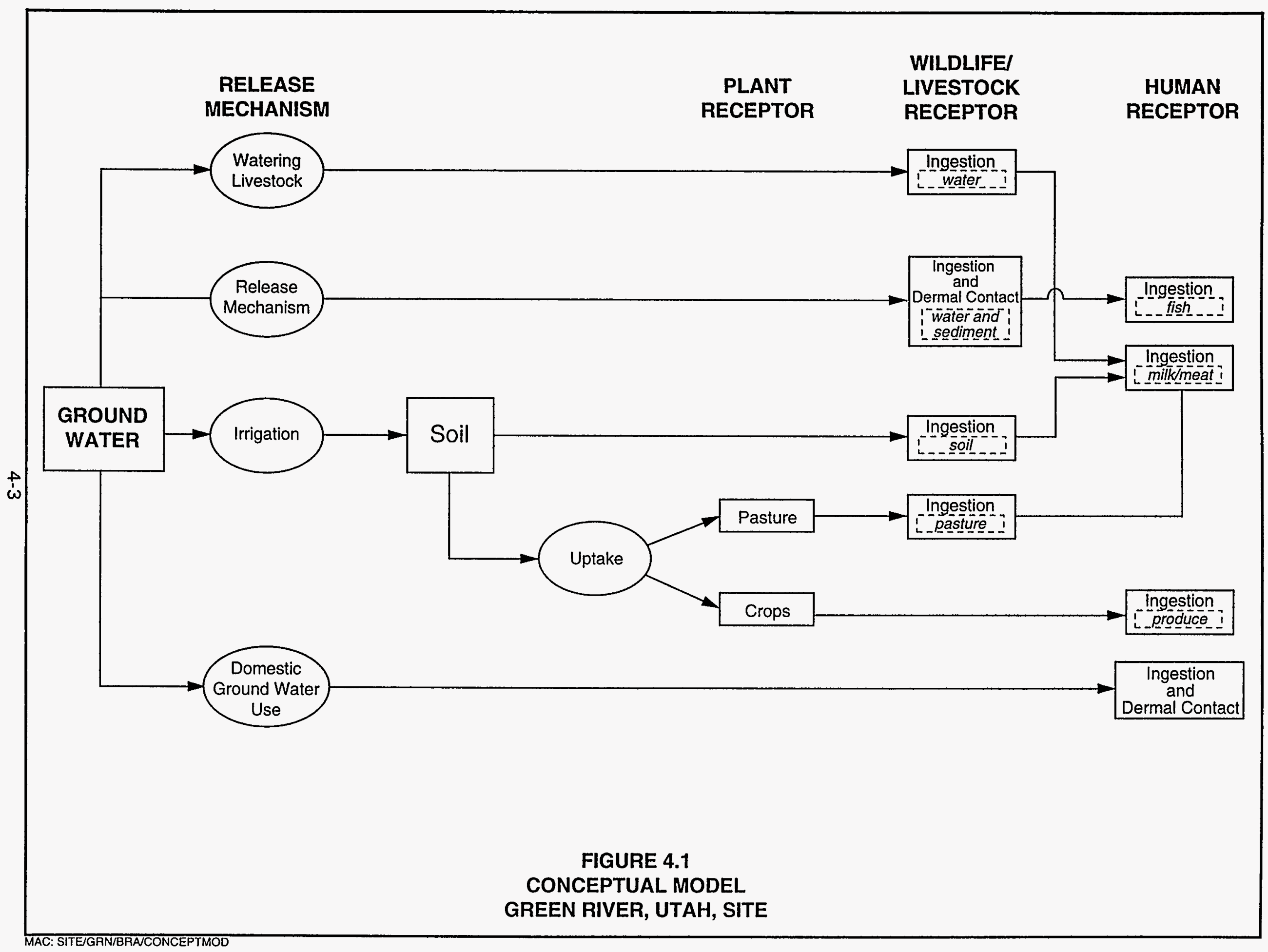


Table 4.1 Exposure dose calculations and equation definitions for the Upper Cedar Mountain aquifer ground water usage in future hypothetical adult scenarios, Green River UMTRA Project site, Green River, Utah

\begin{tabular}{|c|c|c|c|c|}
\hline \multirow[b]{2}{*}{$\begin{array}{l}\text { Contaminant of } \\
\text { potential concern }\end{array}$} & \multirow[b]{2}{*}{$\begin{array}{c}\mathrm{Cw}^{\mathrm{a}} \\
(\mathrm{mg} / \mathrm{L})\end{array}$} & \multicolumn{2}{|c|}{$\begin{array}{c}\text { Ground water exposure doses } \\
\text { (mg/kg-day) }\end{array}$} & \multirow{2}{*}{$\begin{array}{c}\text { Dermal } \\
\text { absorption } \\
\text { Water ingestion }\end{array}$} \\
\hline & & Ingestion & $\begin{array}{c}\text { Dermal } \\
\text { absorption }\end{array}$ & \\
\hline \multicolumn{5}{|l|}{ Noncarcinogenic effects } \\
\hline Arsenic & 0.085 & $2 \mathrm{E}-03$ & $5 \mathrm{E}-06$ & 0.002 \\
\hline Manganese & 2.4 & $7 \mathrm{E}-02$ & $1 \mathrm{E}-04$ & 0.002 \\
\hline Molybdenum & 0.21 & $6 \mathrm{E}-03$ & $1 \mathrm{E}-05$ & 0.002 \\
\hline Nitrate & 1934 & $\begin{array}{l}5 E+01 \\
3 E+02^{C}\end{array}$ & $1 E-01$ & 0.002 \\
\hline Selenium & 0.60 & $2 \mathrm{E}-02$ & $3 E-05$ & 0.002 \\
\hline Sodium & 4500 & $1 E+02$ & $2 E-01$ & 0.002 \\
\hline Sulfate & 9057 & $\begin{array}{l}2 E+02 \\
1 E+03^{C}\end{array}$ & $5 E-01$ & 0.002 \\
\hline Uranium & 3.45 & $9 \mathrm{E}-02$ & $2 E-04$ & 0.002 \\
\hline Vanadium & 0.22 & $5 E-03$ & $1 \mathrm{E}-05$ & 0.002 \\
\hline \multicolumn{5}{|l|}{ Carcinogenic effects } \\
\hline Arsenic & 0.085 & $2 \mathrm{E}-03$ & $3 E-06$ & 0.002 \\
\hline Radium-226 (pCi/L) & $4.2^{d}$ & $1 E+05^{e}$ & $3 E+02^{e}$ & 0.002 \\
\hline Uranium $(p C i / L)$ & $2367^{f}$ & $8 E+07^{e}$ & $2 E+05^{e}$ & 0.002 \\
\hline
\end{tabular}

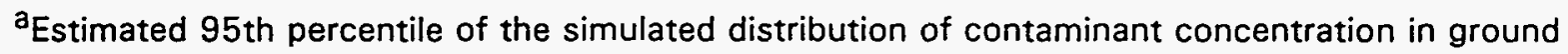
water.

${ }^{b}$ Ratio of the dermal absorption exposure dose to the ground water ingestion exposure dose.

${ }^{\mathrm{C}}$ Exposure dose calculated for infants (0 to 1 year).

${ }^{\mathrm{d}}$ Concentration of radium-226 is represented by maximum observed value.

Units are $\mathrm{pCi} /$ lifetime.

${ }^{f}$ Maximum observed concentration was used to simulate uranium concentration distribution; uranium-234 and uranium-238 combined; $1 \mathrm{mg}$ uranium is assumed to equal $686 \mathrm{pCi}$.

$\mathrm{mg} / \mathrm{kg}$-day - milligrams per kilogram of body weight per day.

$\mathrm{pCi} / \mathrm{L}$ - picocuries per liter. 
Table 4.1 Exposure dose calculations and equation definitions for the Upper Cedar Mountain aquifer ground water usage in future hypothetical adult scenarios, Green River UMTRA Project site, Green River, Utah (Concluded)

\section{Equation definitions for exposure dose calculations}

Ingestion of ground water

Chemicals:

$$
\text { Chronic daily intake }\left(\mathrm{mg} / \mathrm{kg} \text {-day) }=\frac{C W \times I R w \times E F \times E D}{B W \times A T}\right.
$$

Radionuclides:

$$
\text { Lifetime intake }(\mathrm{pCi} / \text { lifetime })=\mathrm{CW} \times \mathrm{IRW} \times \mathrm{EF} \times \mathrm{ED}
$$

\section{Dermal contact with ground water}

Chemicals:

$$
\text { Chronic daily intake }(\mathrm{mg} / \mathrm{kg}-\text { day })=\frac{(\mathrm{CW} \times \mathrm{SA} \times \mathrm{PC} \times \mathrm{Cf}) \times E T \times E F \times E D}{B W \times A T}
$$

Radionuclides:

$$
\text { Lifetime intake }(p C i / l i f e t i m e)=C w \times S A \times P c \times C f \times E T \times E F \times E D
$$

Where:

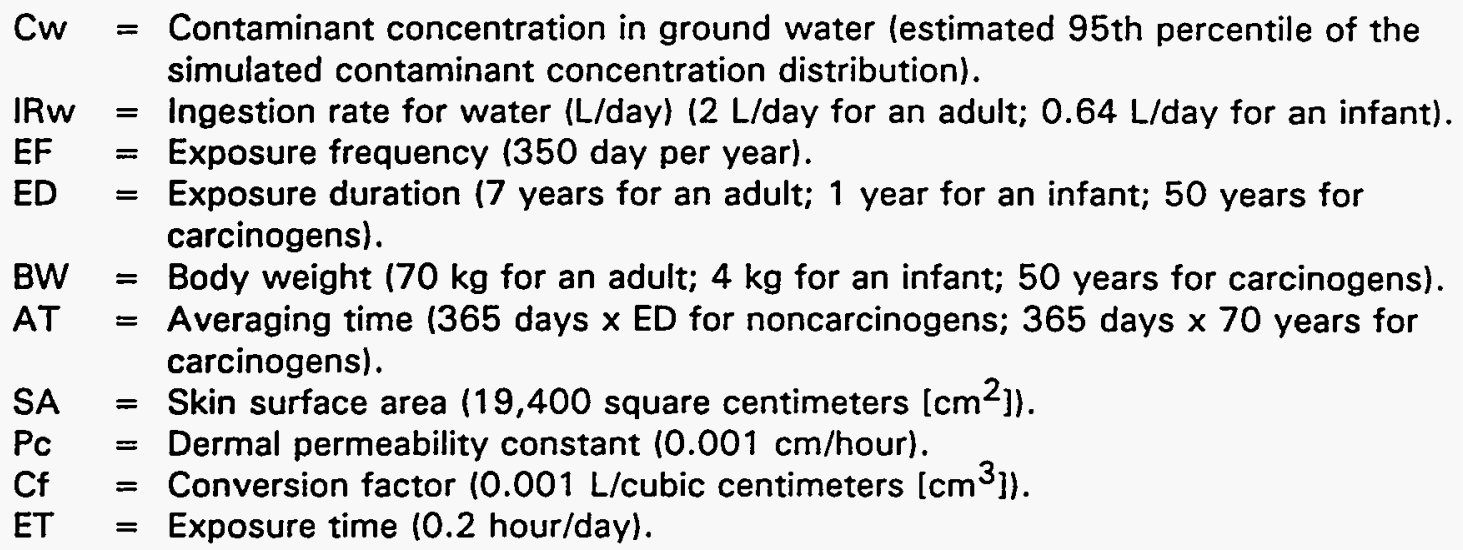


A dermal dose is an absorbed dose, whereas an ingested dose is a total dose of which only some percentage will be absorbed. The very low exposure contribution of dermal absorption, 0.2 percent, is assumed to be insignificant relative to ingestion. Based on these results, dermal absorption was eliminated from more quantitative detailed evaluation.

\subsubsection{Ingestion of ground water-irrigated produce}

This exposure route was also evaluated for its relative significance to the drinking water ingestion route. The results of the screening are shown in Table 4.2. The assumptions for this evaluation will probably overestimate the potential for exposure from this route, because it is assumed that this garden would be the source of all garden produce in the diet. The results of this screening show that for the contaminants of potential concern at this site, ingesting garden vegetables and fruit irrigated with contaminated ground water would lead to potential exposures of 3 percent or less of that associated with drinking water ingestion. Based on these results, this pathway is eliminated from further quantitative evaluation.

4.2.4 Ingestion of meat or milk from livestock ingesting ground water

These pathways were eliminated from further consideration, because the concentrations of nitrate and sulfate are so high that livestock probably would not survive chronic ingestion of the water. If the livestock cannot consume the water, there is no potential for contaminants to bioaccumulate or transfer to meat tissue or milk. The direct toxicity to livestock is evaluated in Section 7.0.

The results of the pathway screening analyses indicate that drinking water ingestion is the dominant pathway; this pathway is further evaluated probabilistically in Section 4.4. The potential toxicity of exposure from these other pathways relative to the drinking water exposure pathway, and the contribution from these pathways if the drinking water exposure pathway is eliminated, is discussed qualitatively in Section 6.0.

\subsection{EXPOSURE CONCENTRATIONS}

The exposure concentration of a contaminant in ground water is the average concentration contacted by an individual over a specified period of exposure. In this evaluation, the contaminant concentrations are assumed to be in a steady state, although actual contaminant concentrations (and therefore exposures) are expected to decrease with time because surface remediation has been completed at the site. Chronic exposure for noncarcinogens is considered to be exposure for any period over 7 years. For carcinogens, a lifetime exposure over 50 years is considered.

Exposure concentrations are evaluated as a probability of occurrence based on ground water quality data from the most contaminated monitor wells. Because of the discontinuities of water quality data for the Upper Cedar Mountain 
Table 4.2 Exposure dose calculations and equation definitions for the Upper Cedar Mountain aquifer ground waterirrigated produce ingestion in future hypothetical adult scenarios, Green River UMTRA Project site, Green River, Utah

\begin{tabular}{|c|c|c|c|c|c|c|c|}
\hline \multirow{2}{*}{$\begin{array}{c}\text { Contaminant of } \\
\text { potential concern }\end{array}$} & \multirow{2}{*}{$\begin{array}{l}\mathrm{Cw}^{\circ} \\
(\mathrm{mg} / \mathrm{L})\end{array}$} & \multirow{2}{*}{$\begin{array}{c}K d \\
(L / k g)\end{array}$} & \multirow[b]{2}{*}{ Bv } & \multirow[b]{2}{*}{$\mathrm{Br}$} & \multicolumn{2}{|c|}{$\begin{array}{l}\text { Garden produce ingestion exposure doses } \\
\text { (mg/kg-day) }\end{array}$} & \multirow{2}{*}{$\begin{array}{c}\begin{array}{c}\text { Total produce } \\
\text { ingestion }^{\mathrm{b}}\end{array} \\
\text { Water ingestion }\end{array}$} \\
\hline & & & & & Vegetative parts & Reproductive parts & \\
\hline \multicolumn{8}{|l|}{ Noncarcinogenic effects } \\
\hline Arsenic & 0.085 & 200 & 0.04 & 0.006 & $3 E-05$ & 3E-06 & 0.02 \\
\hline Manganese & 2.4 & 65 & 0.25 & 0.05 & $2 \mathrm{E}-03$ & $2 E-04$ & 0.03 \\
\hline Molybdenum & 0.21 & 20 & 0.25 & 0.06 & $5 E-05$ & 7E-06 & 0.01 \\
\hline Nitrate & 1934 & 0.01 & 30 & 30 & $3 E-02$ & $2 \mathrm{E}-02$ & 0.001 \\
\hline Selenium & 0.6 & 300 & 0.025 & 0.025 & $2 \mathrm{E}-04$ & $1 \mathrm{E}-04$ & 0.02 \\
\hline Sodium & 4500 & 100 & 0.075 & 0.055 & $2 E+00$ & 7E-01 & 0.03 \\
\hline Sulfate & 9057 & 7.5 & 0.5 & 0.5 & $2 E+00$ & $1 E+00$ & 0.02 \\
\hline Uranium & 3.45 & 450 & 0.0085 & 0.004 & $6 \mathrm{E}-04$ & $2 \mathrm{E}-04$ & 0.009 \\
\hline Vanadium & 0.2 & 1000 & 0.0055 & 0.003 & $5 E-05$ & $2 \mathrm{E}-05$ & 0.01 \\
\hline \multicolumn{8}{|l|}{ Carcinogenic effects } \\
\hline Arsenic & 0.085 & 200 & 0.04 & 0.006 & $2 \mathrm{E}-05$ & $2 \mathrm{E}-06$ & 0.01 \\
\hline Radium-226 (pCi/L) & $1.3^{c}$ & 24.3 & 0.015 & 0.0015 & $3 E+01^{d}$ & $2 E+00^{d}$ & 0.0003 \\
\hline Uranium $(p \mathrm{Ci} / \mathrm{L})$ & $2367^{e}$ & 450 & 0.0085 & 0.004 & $5 E+05^{d}$ & $1 E+05^{d}$ & 0.01 \\
\hline
\end{tabular}

${ }^{8}$ Estimated 95 th percentile of the simulated distribution of contaminant concentration in ground water.

${ }^{b}$ Ratio of the total garden produce ingestion exposure dose to the ground water ingestion exposure dose.

${ }^{\mathrm{c} C o n c e n t r a t i o n}$ of radium-226 is represented by maximum observed value.

dUnits are pCi/lifetime.

${ }^{\mathrm{e}}$ Maximum observed concentration was used to simulate uranium concentration distribution; uranium-234 and uranium-238 combined; $1 \mathrm{mg}$ uranium is assumed to equal $686 \mathrm{pCi}$. 


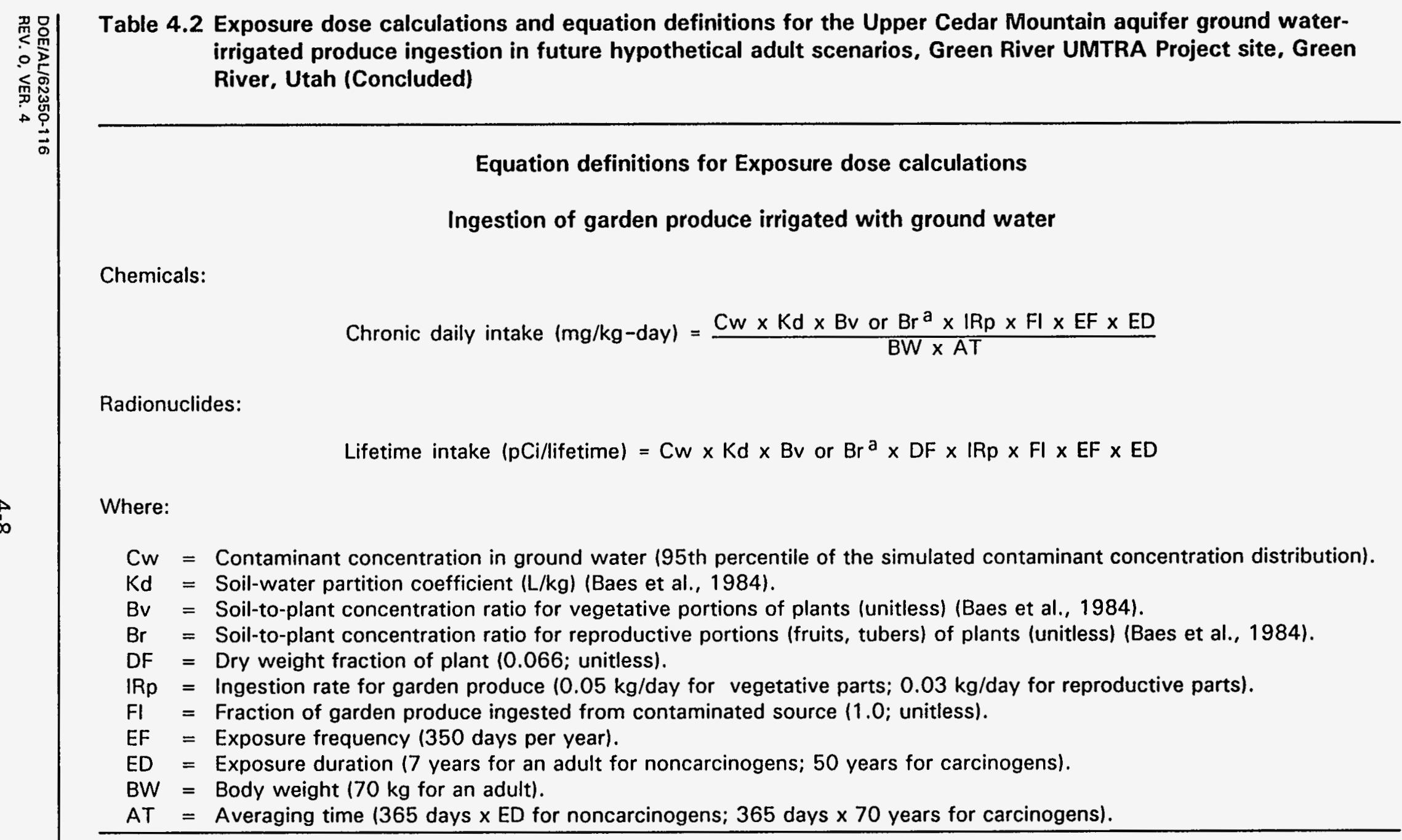

${ }^{\mathrm{a} E x p o s u r e ~ d o s e s ~ d u e ~ t o ~ c o n s u m p t i o n ~ o f ~ v e g e t a t i v e ~ p o r t i o n s ~ a n d ~ r e p r o d u c t i v e ~ p o r t i o n s ~ o f ~ g a r d e n ~ p r o d u c e ~ a r e ~ c a l c u l a t e d ~ s e p a r a t e l y . ~}$ 
aquifer, both in time and space (refer to Section 3.0), data collected prior to surface remediation (i.e., from 1986 to 1988 ) were used to develop probability distributions. However, in some cases more recent data were available. The analysis of molybdenum and vanadium toxicity was conducted based on concentrations observed in monitor wells 562, 581, 701, 703,807, 813, and 816 from 1986 to 1988 . Manganese, nitrate, and uranium levels were consistently higher in well 701 than in other wells; therefore, the analyses of manganese, nitrate, and uranium toxicities were based on concentrations observed in well 701 for the period 1986 to 1988 . Selenium levels were consistently highest in new wells 176 and 179; thus, selenium toxicity was analyzed based on concentrations observed in both wells 176 and 179 during 1990 to 1993. Arsenic levels were consistently higher in a still-existing well, 813 , than in other on-site wells; therefore, the analysis of arsenic toxicity was based on concentrations observed in well 813 from 1989 to 1993. Finally, sodium and sulfate toxicities were analyzed based on concentrations in well 807 during 1989 to 1990 , because sodium and sulfate levels were consistently highest in well 807 . The maximum observed concentration measured in ground water from monitor well 179 from 1990 to 1993 was used for radium-226 and other longer-lived progeny of the uranium series. Carcinogenic effects associated with exposure to radium-226, lead-210, polonium-210, and thorium-230 are evaluated in Section 6.0.

The probability distribution selected for each contaminant reflected the same mean, median, standard deviation, and shape as were observed in actual water quality data. Probability distributions for sodium, sulfate, and uranium are based on an observed increasing trend in concentrations between 1987 and 1990. The upper tail of the distributions was truncated at the 99th percentile. For every contaminant, this highest allowable concentration was higher than the maximum observed concentration in the historical water quality data. The software package @RISK (Palisade Corp., 1992) was used to generate probability curves for the contaminants of potential concern. The results are shown in Figures 4.2 through 4.10 .

\subsection{ESTIMATION OF INTAKE}

Individuals within the population of future residents are anticipated to vary with respect to water consumption habits, stable body weight, and length of residence in the potential contamination zone. Consequently, health risks associated with ground water consumption also will vary among members of the population.

To adequately describe the range of potential risks to the future population, naturally occurring variability in daily intake and body weight were incorporated in this assessment through probability distributions selected from published public health and census documents for the United States. All distributions were truncated at the upper and lower 0.01 percentile. Values disallowed through this truncation have a probability of less than 1 in 10,000 of occurring within the hypothetical population. 


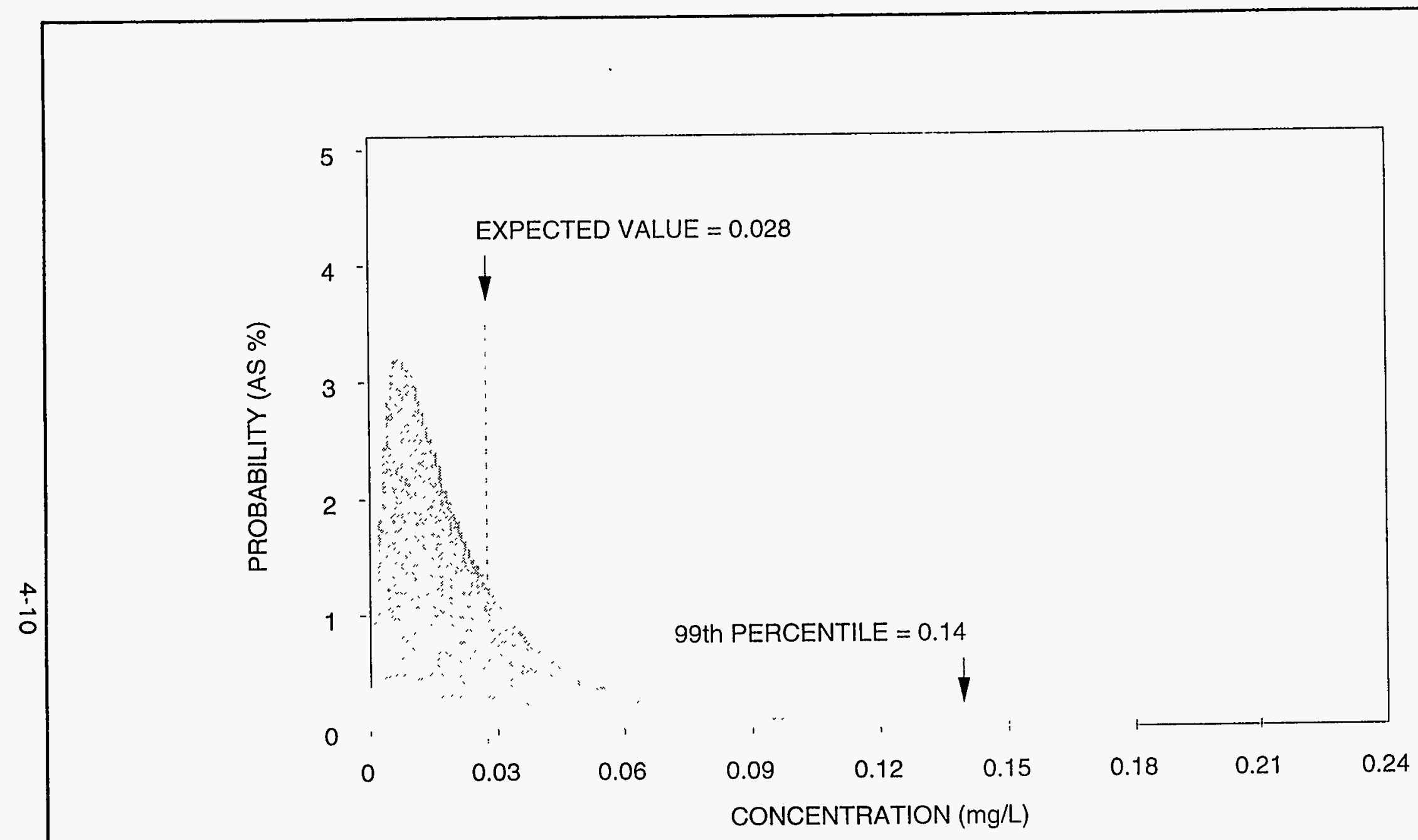

FIGURE 4.2

PROBABILITY DISTRIBUTION OF ARSENIC CONCENTRATIONS

FOR THE UPPER CEDAR MOUNTAIN AQUIFER

GREEN RIVER, UTAH, SITE 


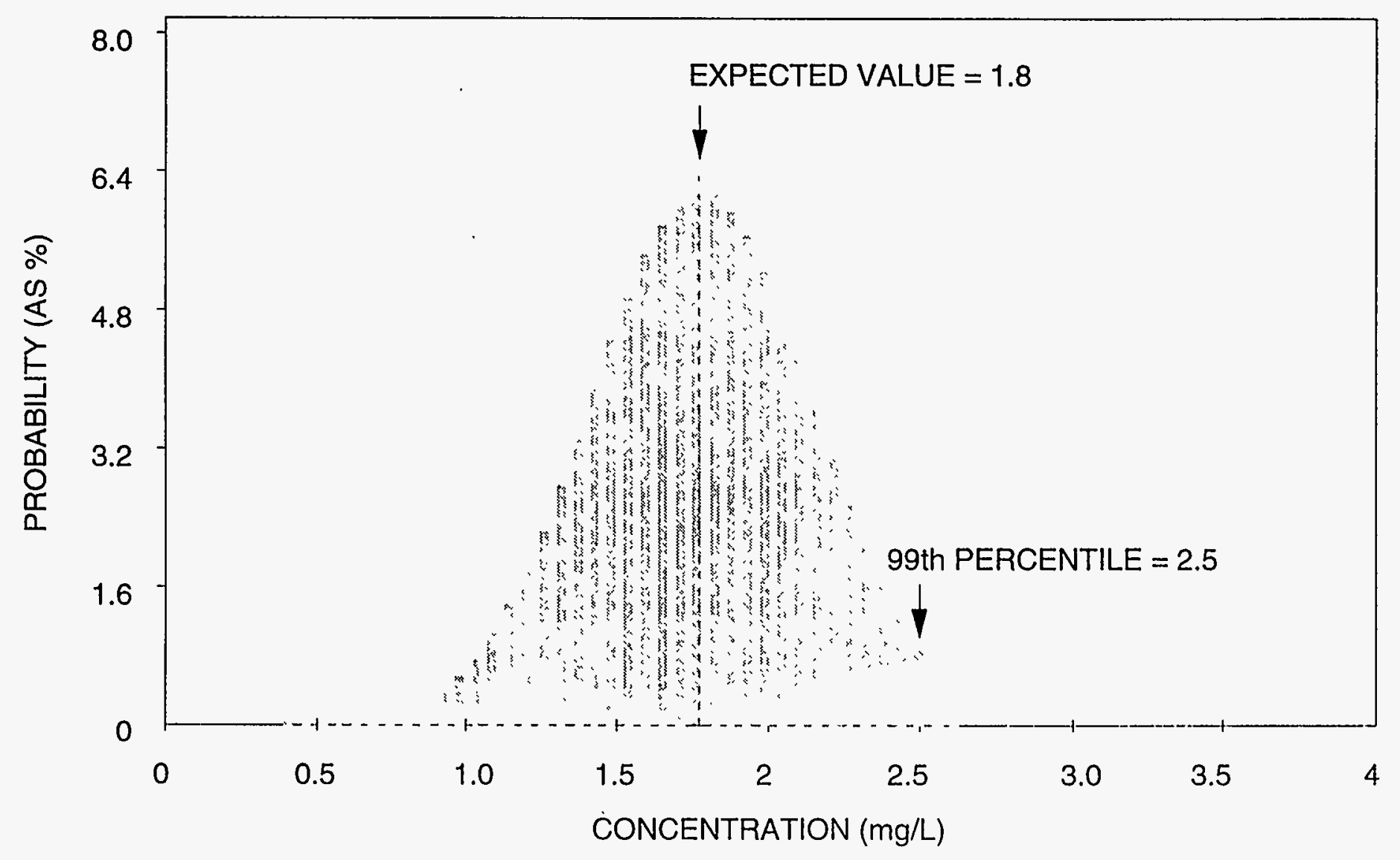

FIGURE 4.3

PROBABILITY DISTRIBUTION OF MANGANESE CONCENTRATIONS

FOR THE UPPER CEDAR MOUNTAIN AQUIFER

GREEN RIVER, UTAH, SITE 


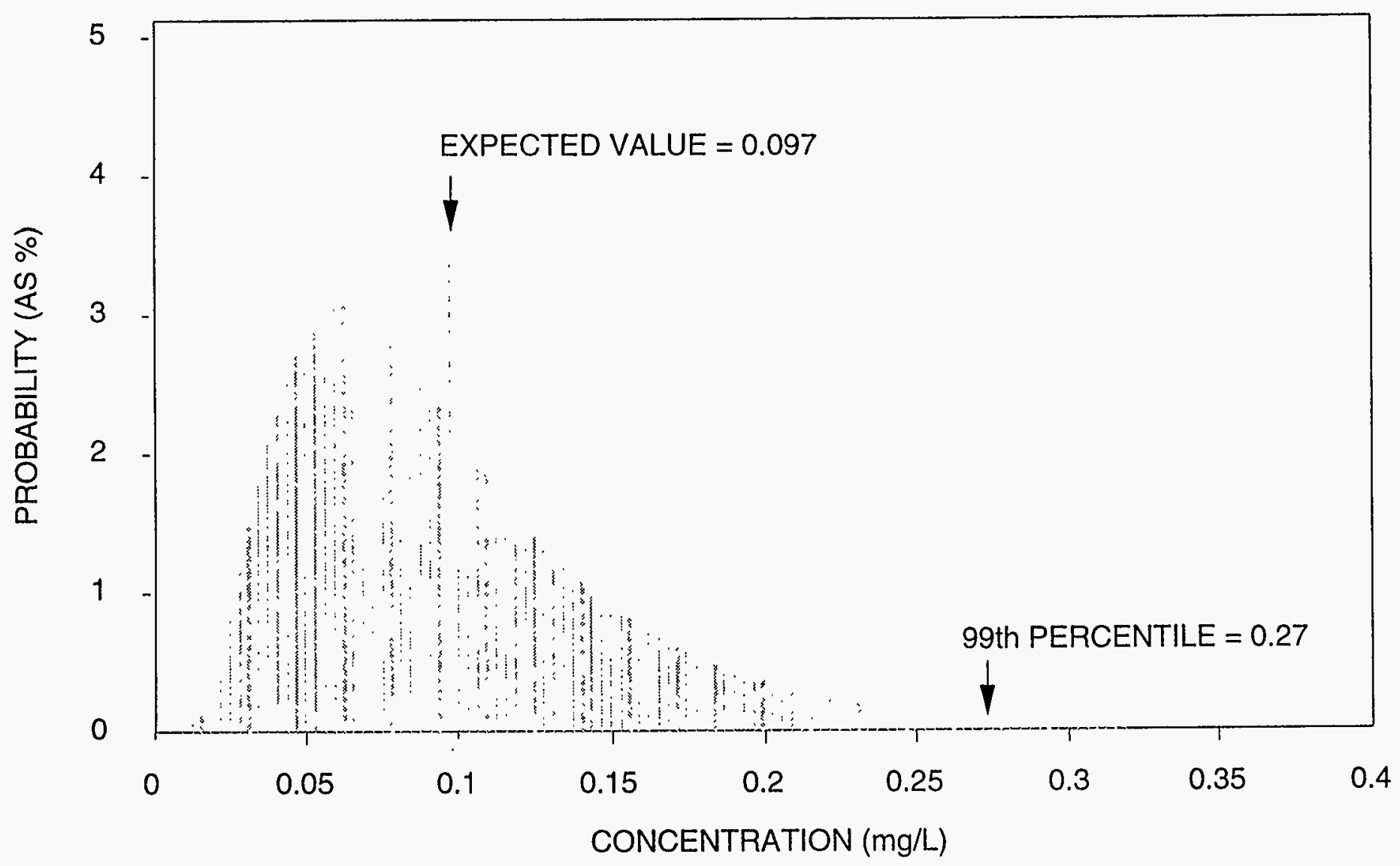

FIGURE 4.4

PROBABILITY DISTRIBUTION OF MOLYBDENUM CONCENTRATIONS FOR THE UPPER CEDAR MOUNTAIN AQUIFER GREEN RIVER, UTAH, SITE 


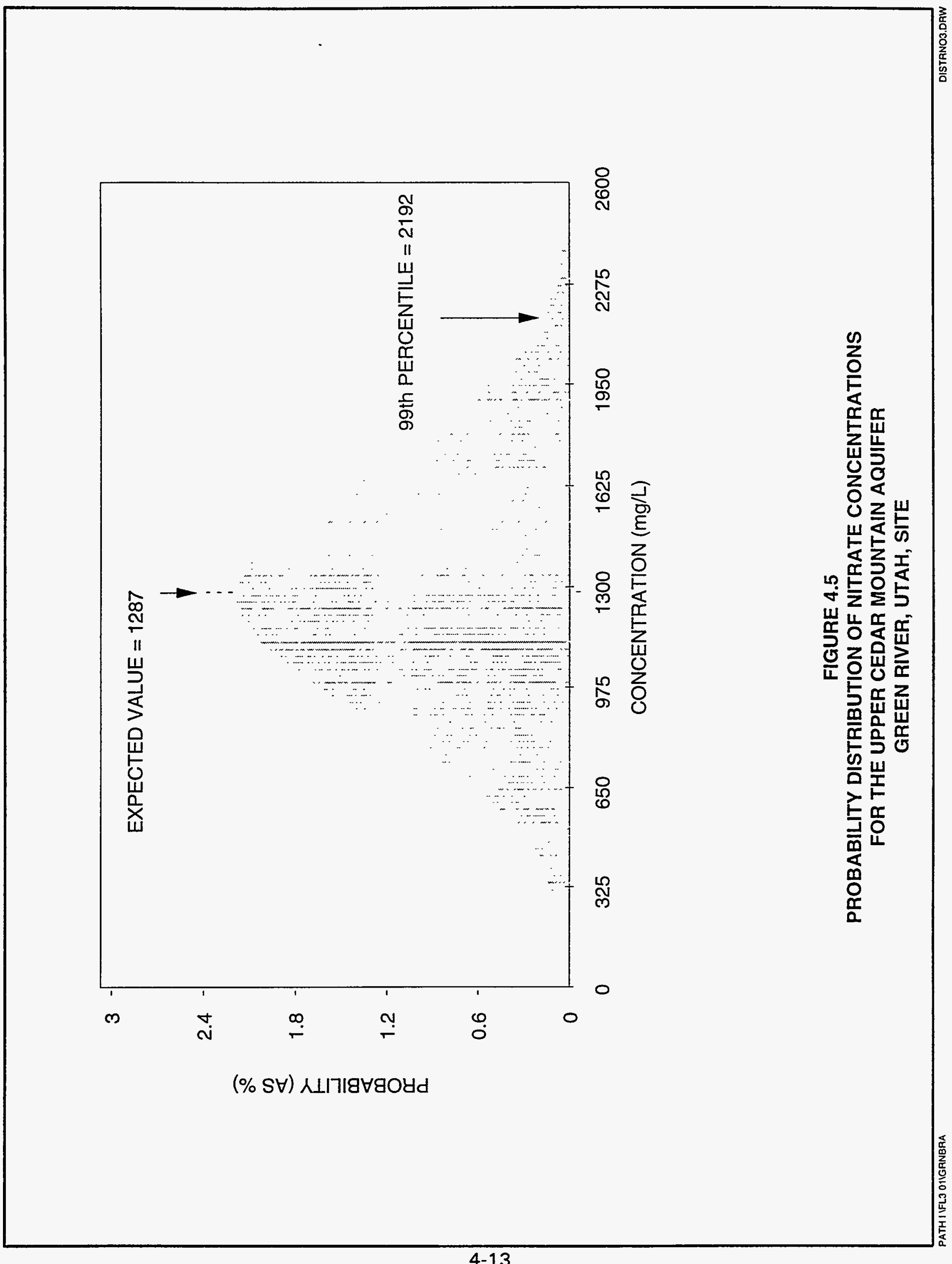




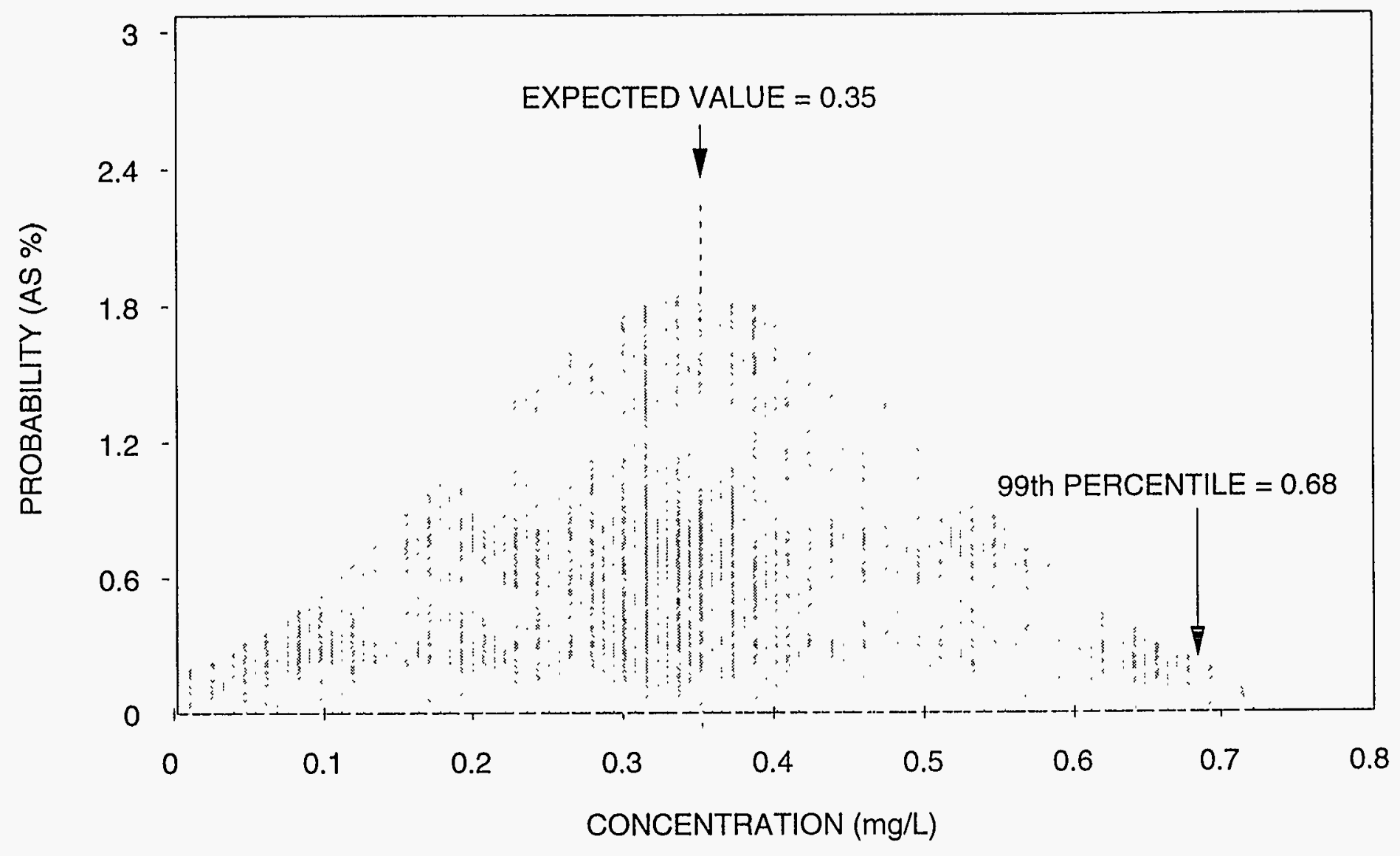

FIGURE 4.6

PROBABILITY DISTRIBUTION OF SELENIUM CONCENTRATIONS

FOR THE UPPER CEDAR MOUNTAIN AQUIFER

GREEN RIVER, UTAH, SITE 


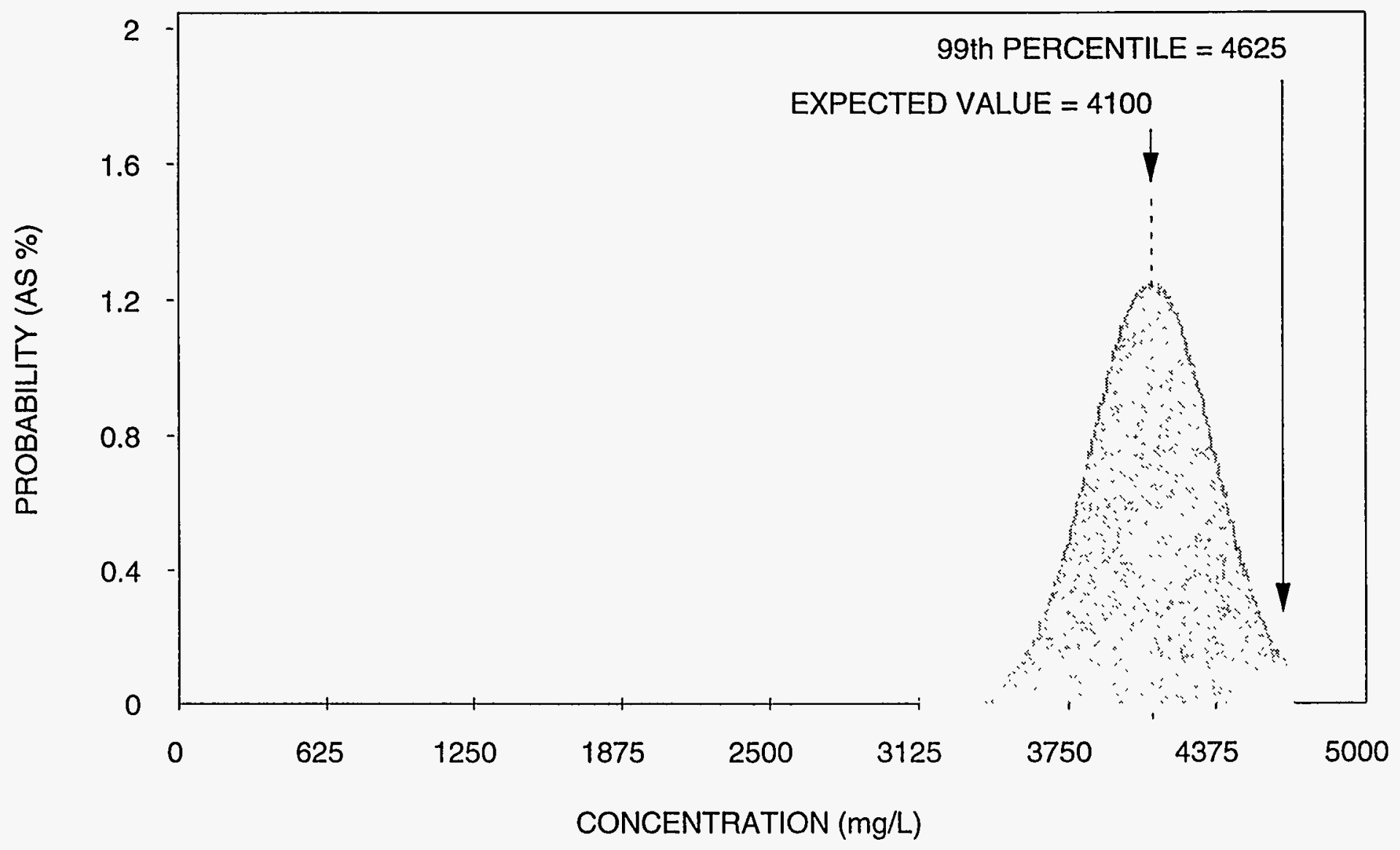

NOTE: CONCENTRATION DISTRIBUTION RESULTS IN PART FROM AN INCREASING TREND IN THE UNDERLYING DATA.

FIGURE 4.7

PROBABILITY DISTRIBUTION OF SODIUM CONCENTRATIONS

FOR THE UPPER CEDAR MOUNTAIN AQUIFER GREEN RIVER, UTAH, SITE 


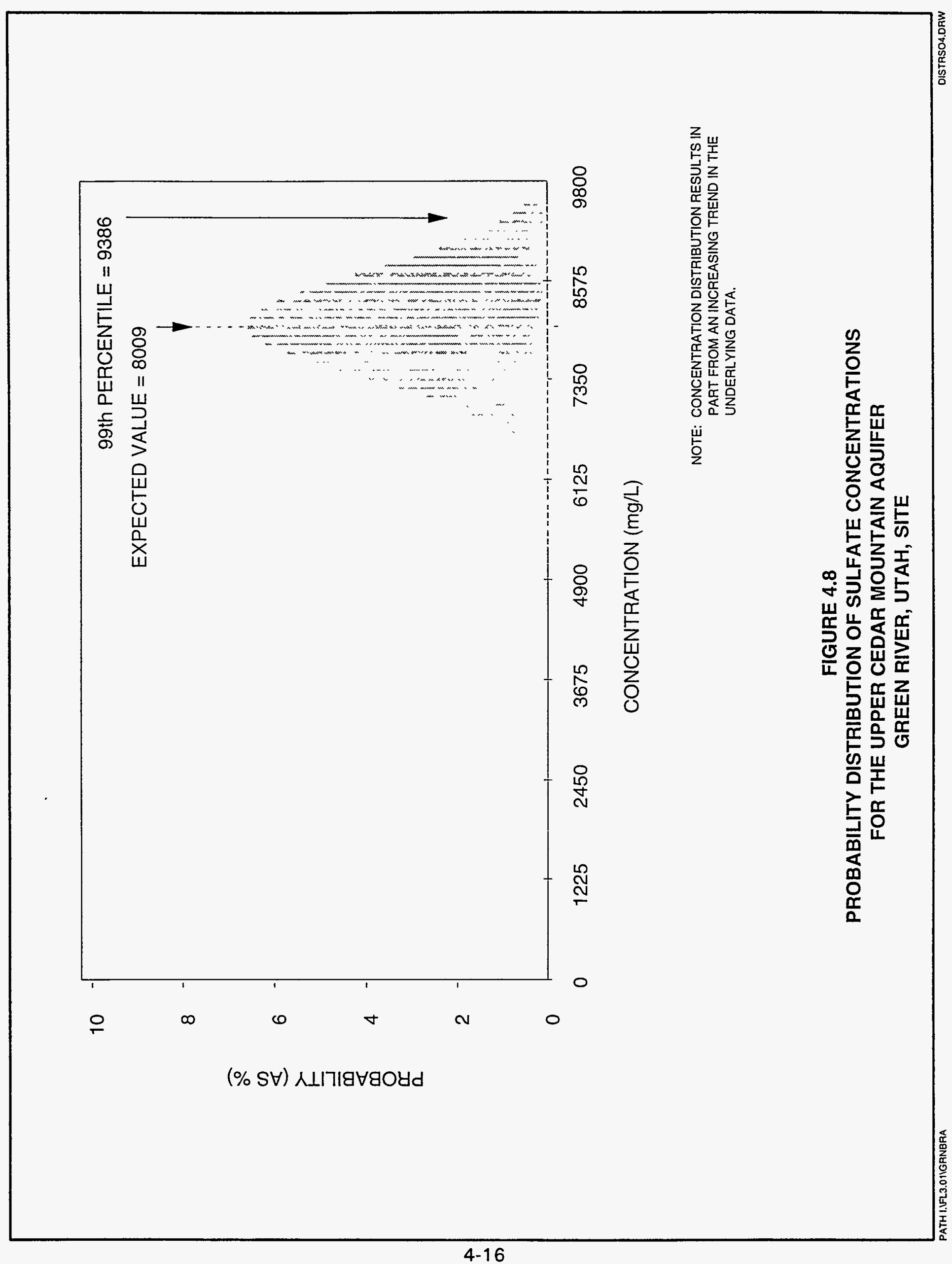



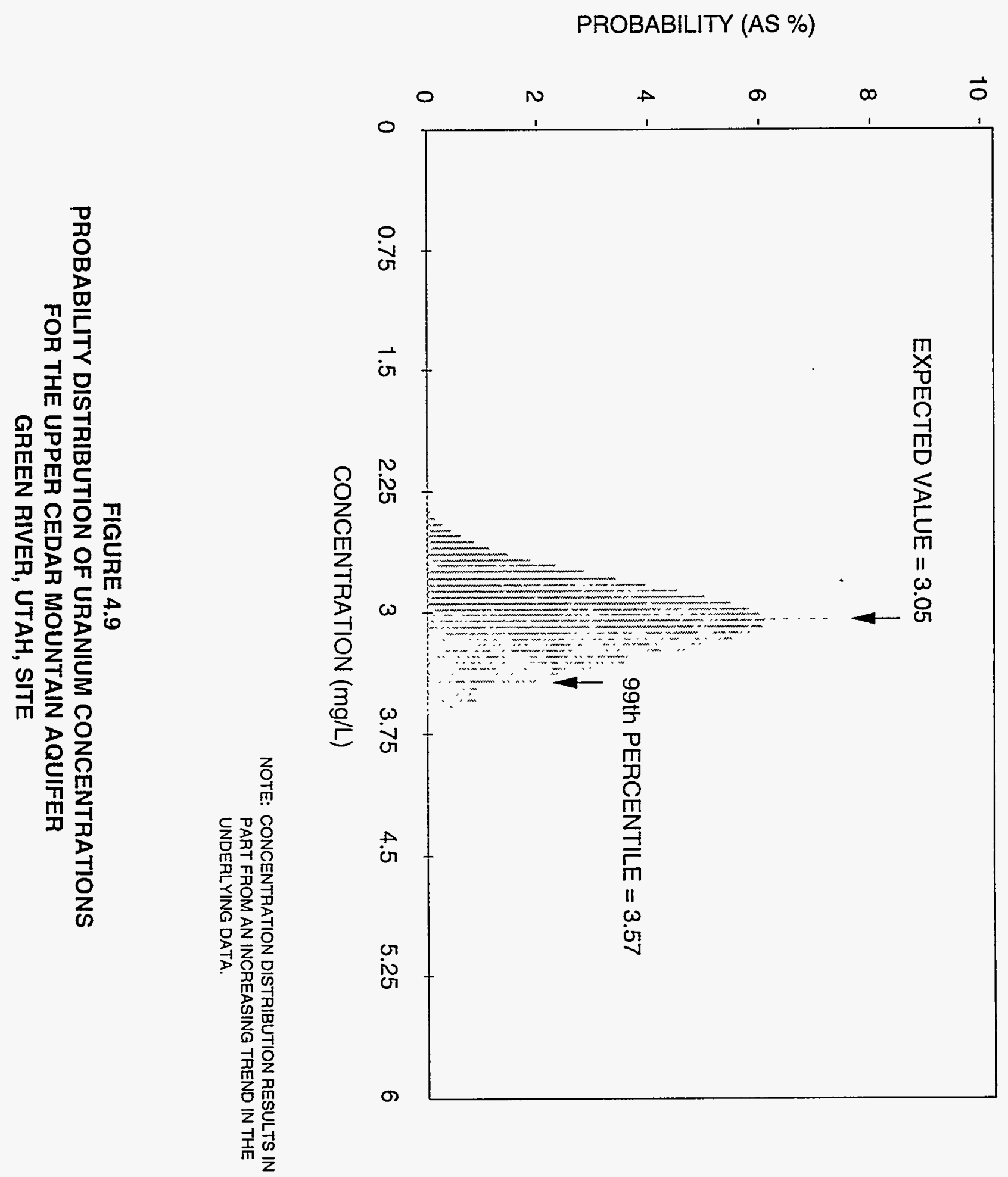


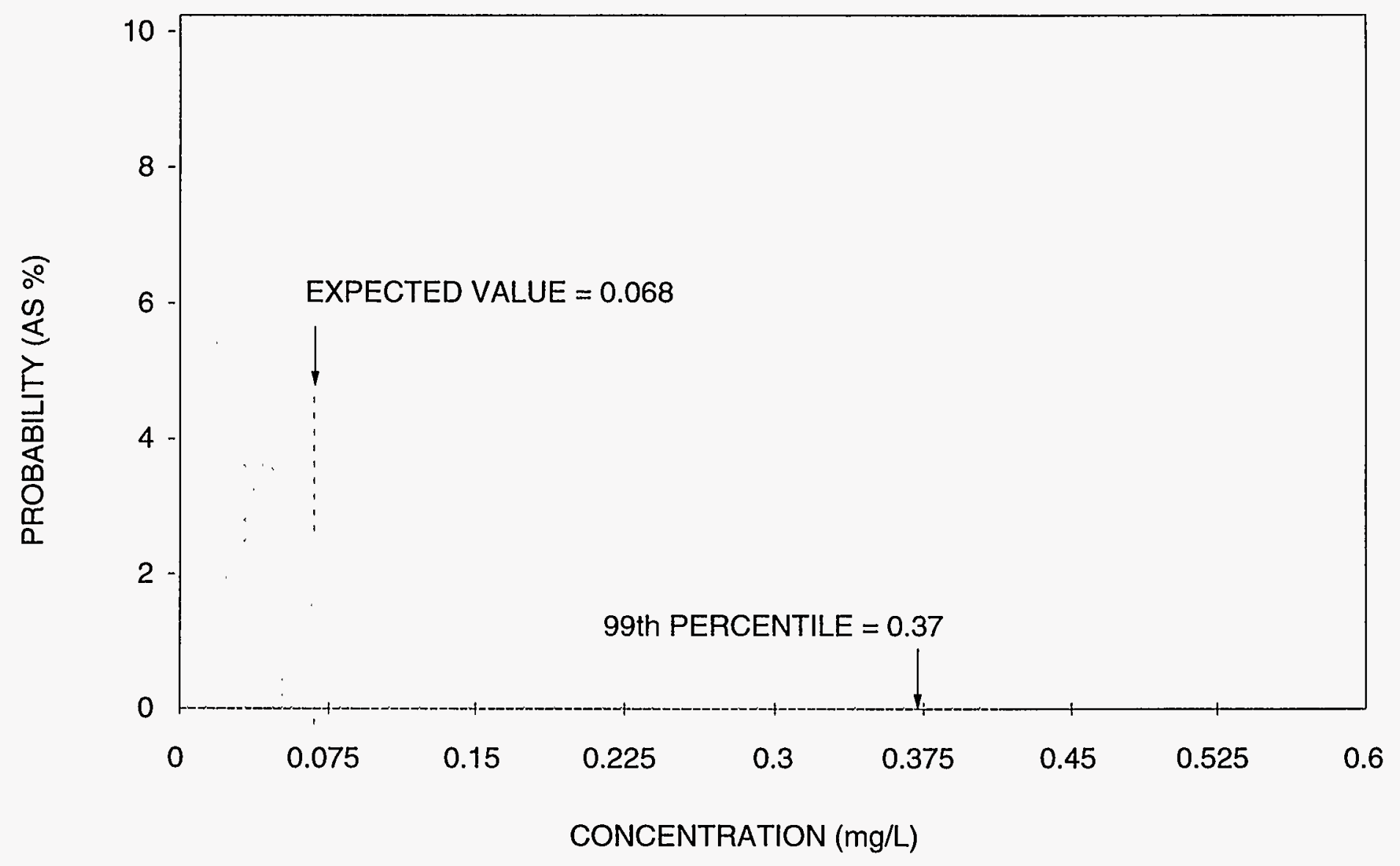

FIGURE 4.10

PROBABILITY DISTRIBUTION OF VANADIUM CONCENTRATIONS

FOR THE UPPER CEDAR MOUNTAIN AQUIFER

GREEN RIVER, UTAH, SITE 
The potential toxicity of noncarcinogenic contaminants in drinking water and potential carcinogenicity of arsenic depend primarily on long-term average daily consumption of the contaminant per kilogram of body weight (measured in milligrams per kilogram per day [mg/kg-day]). "Long-term" is defined as at least 7 years for noncarcinogens and 50 years for arsenic carcinogenicity. For noncarcinogens, chronic daily intake is calculated as follows:

$\underset{\begin{array}{l}\text { Intake } \\ (\mathrm{mg} / \mathrm{kg} \text {-day) }\end{array}=\frac{\begin{array}{c}\text { Concentration } \\ (\mathrm{mg} / \mathrm{L})\end{array}}{\begin{array}{c}\text { Ingestion rate } \\ (\mathrm{L} / \mathrm{day})\end{array} \times \begin{array}{c}\text { Exposure frequency } \\ \text { (days) }\end{array} \times \begin{array}{c}\text { Exposure duration } \\ \text { (years) }\end{array}}}{\begin{array}{c}\text { Body weight } \\ (\mathrm{kg})\end{array}}$

Potential carcinogenicity of arsenic increases with total intake over a lifetime. Therefore, arsenic exposure is estimated as a daily intake of the contaminant per kilogram of body weight averaged over the lifespan exposure duration and is measured in $\mathrm{mg} / \mathrm{kg}$-day. Therefore, for arsenic as a carcinogen, the daily intake is calculated as follows:

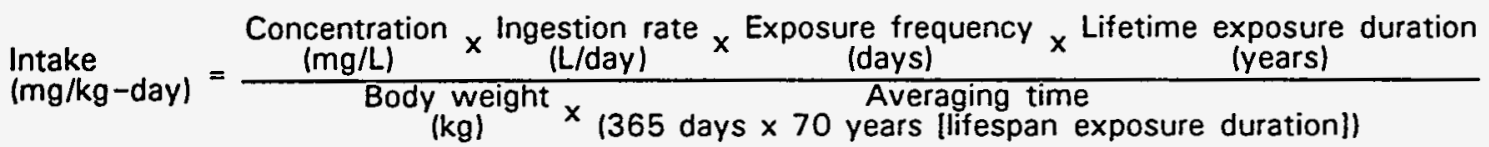

Potential carcinogenicity of radionuclides is thought to increase with total intake over time, instead of with average daily intake as for noncarcinogens. Also, body weight is relatively insignificant in determining risk from exposure. Intake of radionuclides is therefore quantified as total exposure to radioactivity through the residency period of an individual:

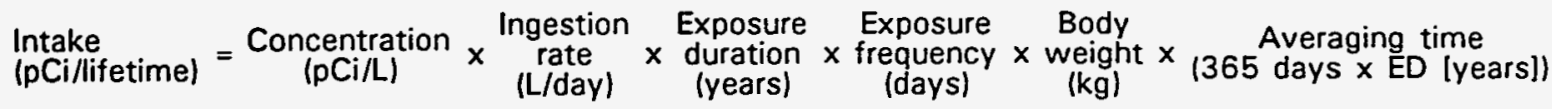

\section{Average daily intake (L/day)}

Lognormal probability distributions were used to describe variations in average daily tap water intake among members of the population (Roseberry and Burmaster, 1992). These distributions were developed from data collected during a 1977-1978 food consumption survey conducted by the U.S. Department of Agriculture. During the survey, total tap water consumption during a 3-day period was recorded for 26,081 survey participants nationwide (Figure 4.11).

\section{Body weight $(\mathrm{kg})$}

Extensive national data on weights of males and females, by age, were collected during a health and nutrition survey conducted from 1976 to 1980 . These data were used to develop lognormal probability distributions for body weight by age, separately by gender. The distributions for males and females 

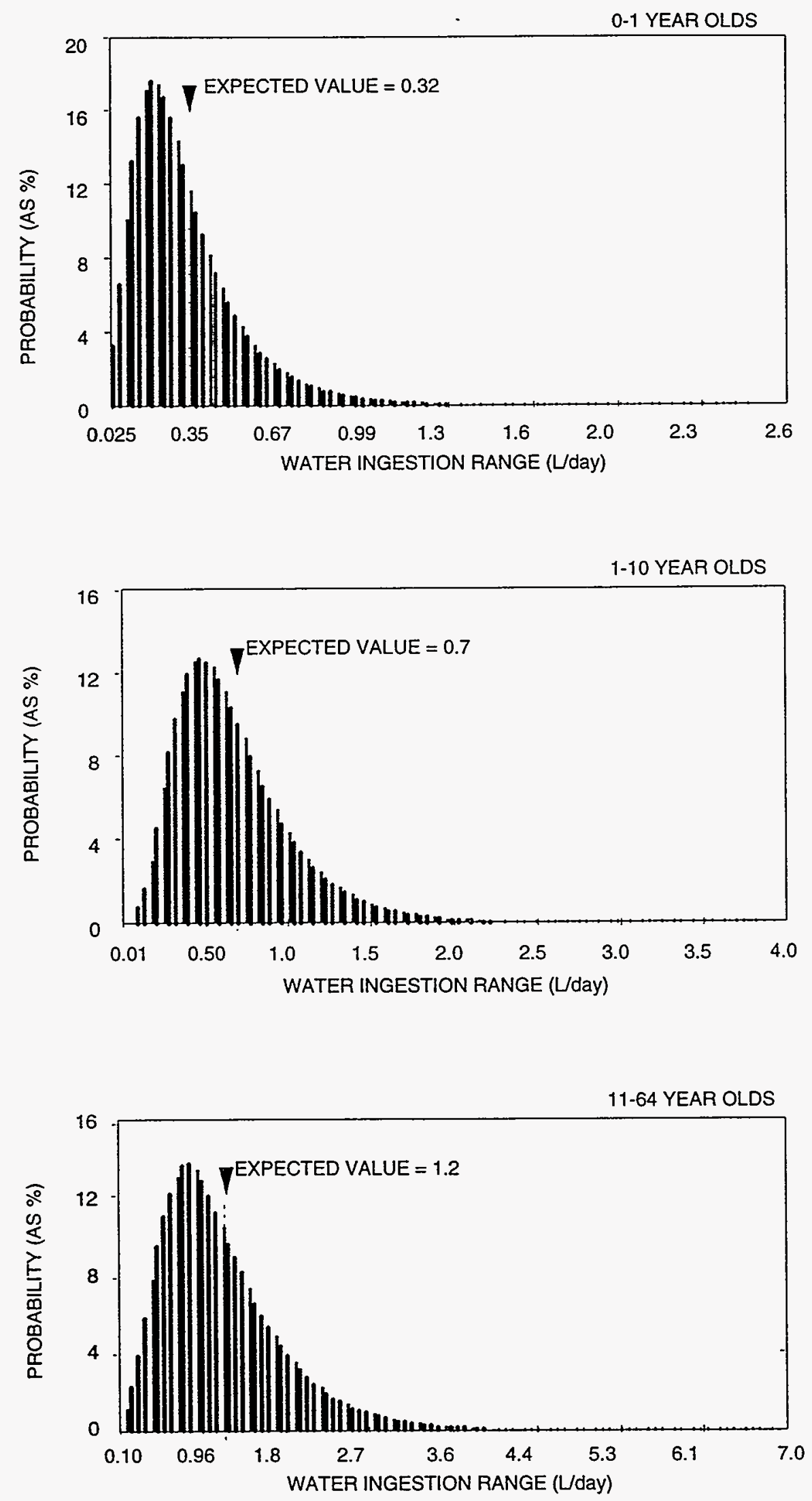

FIGURE 4.11

PROBABILITY DISTRIBUTIONS FOR TAP WATER INGESTION RATES BY AGE GROUP 
were then combined using census data on the national ratio of males and females within each age group (Figure 4.12).

\section{Exposure frequency (days)}

Individuals generally are not present at their homes and drinking water from the same source for 365 days per year. Therefore, calculation of intake assumes only 350 days of exposure per year, allowing for 15 days per year of drinkingwater intake from a different source. Because exposure is expressed and compared in terms of average daily intake, 365 days per year is retained in the averaging-time term in the denominator.

\section{Exposure duration (years)}

Distributions of exposure duration were developed using data collected by the U.S. Department of Commerce, the Bureau of the Census, and the U.S. Department of Housing and Urban Development in 1985 and 1987 (Israeli and Nelson, 1992). For noncarcinogenic effects, the exposure duration in the numerator and denominator of the drinking water intake equations (see equations in Tables 4.1 and 4.2 ) cancels out, assuming all exposures are chronic (i.e., longer than 7 years). Therefore, deviations from the standard residence time assumptions do not affect the results. However, for carcinogenic effects of arsenic, uranium, and other radionuclides, risk is cumulative throughout a lifetime; therefore, deviations from the hypothesized residency distribution could significantly affect the risk estimate. Because Green River is a small urban center where some mobility would be expected, and because residents living near the Green River site can frequently live in the same region for an entire lifetime, a fixed lifetime exposure of 50 years was used to model lifetime cancer risks.

Using the exposure concentration distributions discussed in Section 4.3 and the intake parameter distributions from this section, total intake distributions were simulated for the three age groups (0- to 1, 1- to 10, and 11-to 65-year-olds) by using the @RISK software package (Palisade Corp., 1992) and 10,000 iterations. The 1- to 10-year-old group consistently showed the highest intaketo-body-weight distributions and therefore is the most conservative age group to evaluate. However, because infants are the most sensitive group for nitrate and sulfate toxicity, the intake distributions for this age group (i.e., age 0 to 1 year) are used for these contaminants. Simulated intake distributions for appropriate age groups for the contaminants of potential concern are presented in Figures 4.13 through 4.23 . 

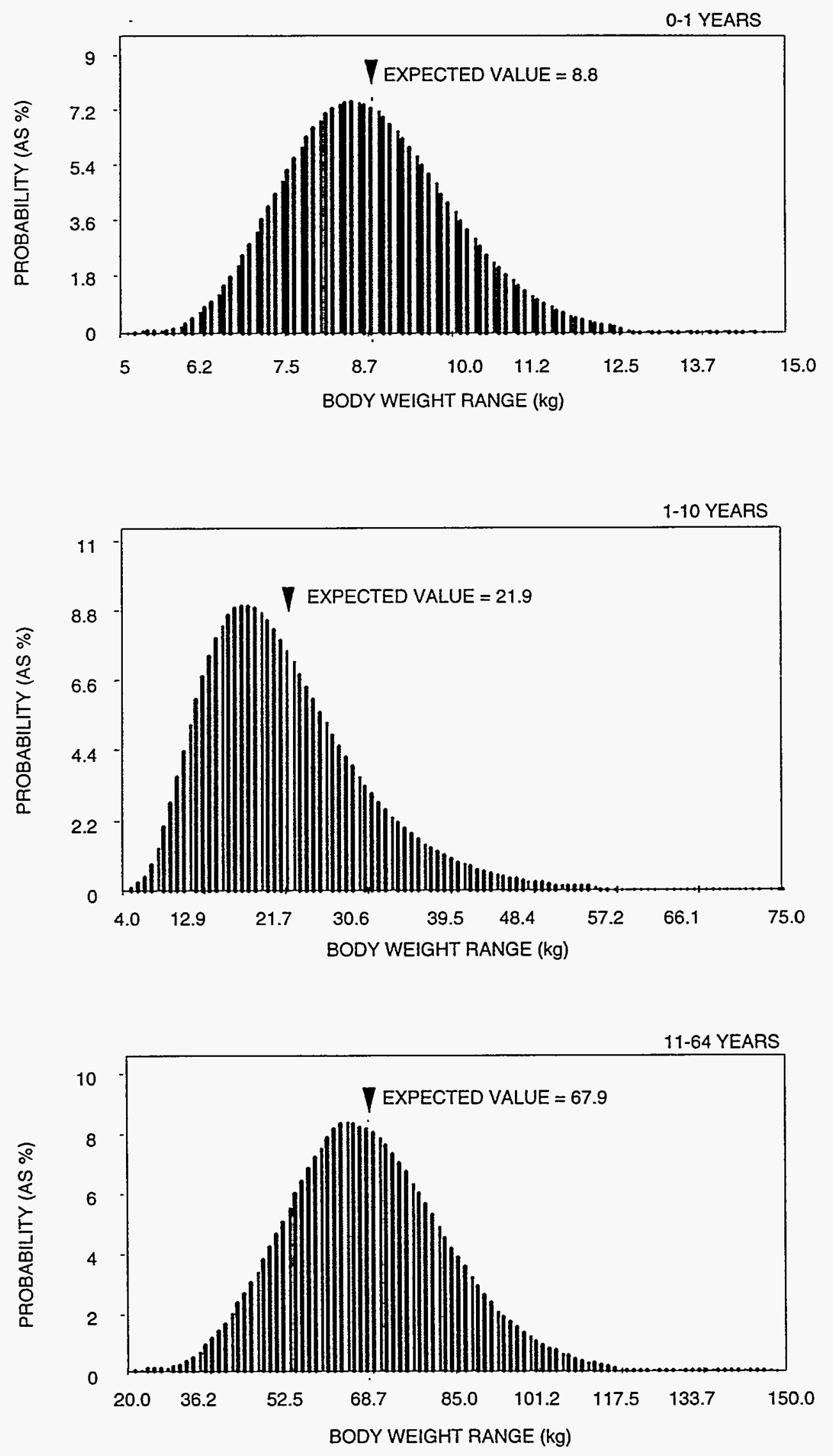

FIGURE 4.12

BODY WEIGHT PROBABILITY DISTRIBUTIONS BY AGE GROUP 


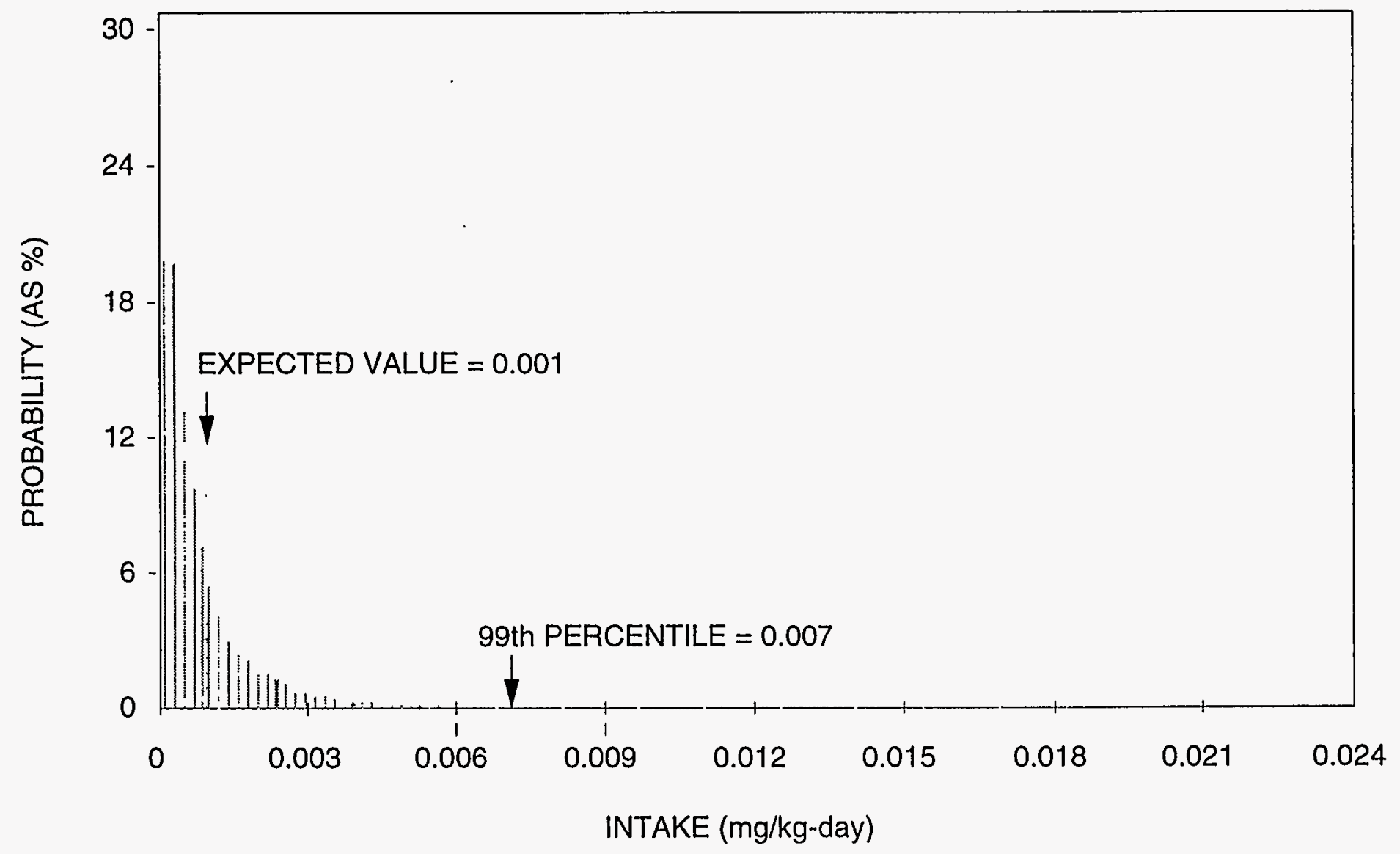

NOTE: AVERAGE POTENTIAL EXPOSURE IS $0.001 \mathrm{mg}$ ARSENIC/kg BODY WEIGHT PER DAY. EXPOSURES FOR CHILDREN ARE MODELED BECAUSE THEIR INTAKE $/ \mathrm{kg}$ BODY WEIGHT IS GREATEST AND NO SENSITIVE POPULATION HAS BEEN IDENTIFIED.

FIGURE 4.13

PROBABILITY DISTRIBUTION OF ARSENIC INTAKES GREEN RIVER, UTAH, SITE 


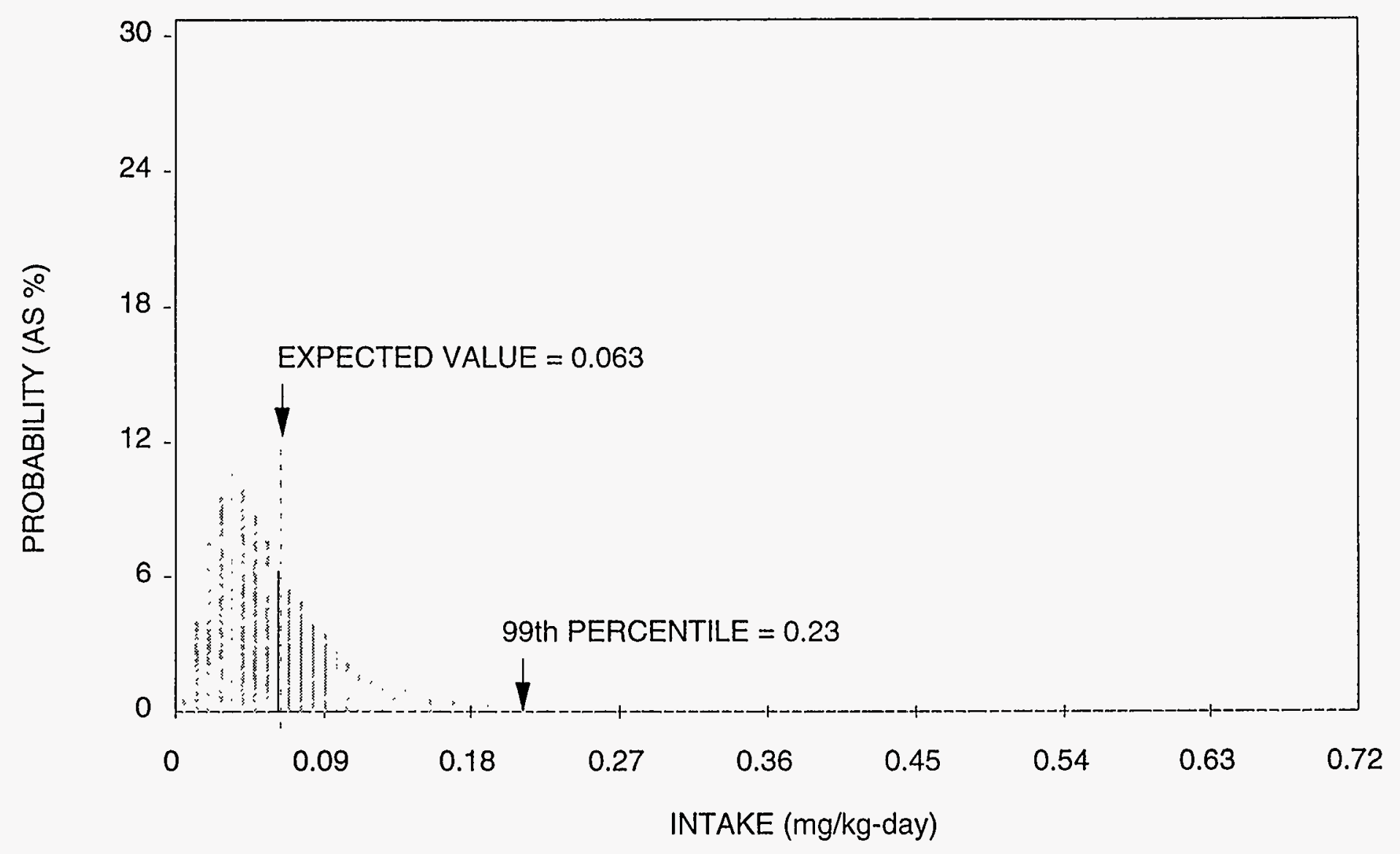

NOTE: AVERAGE POTENTIAL EXPOSURE IS $0.063 \mathrm{mg}$ MANGANESE $/ \mathrm{kg}$ BODY WEIGHT PER DAY. EXPOSURES FOR CHILDREN ARE

MODELED BECAUSE THEIR INTAKE/kg BODY WEIGHT IS GREATEST AND NO SENSITIVE POPULATION HAS BEEN IDENTIFIED.

FIGURE 4.14

PROBABILITY DISTRIBUTION OF MANGANESE INTAKES

GREEN RIVER, UTAH, SITE 


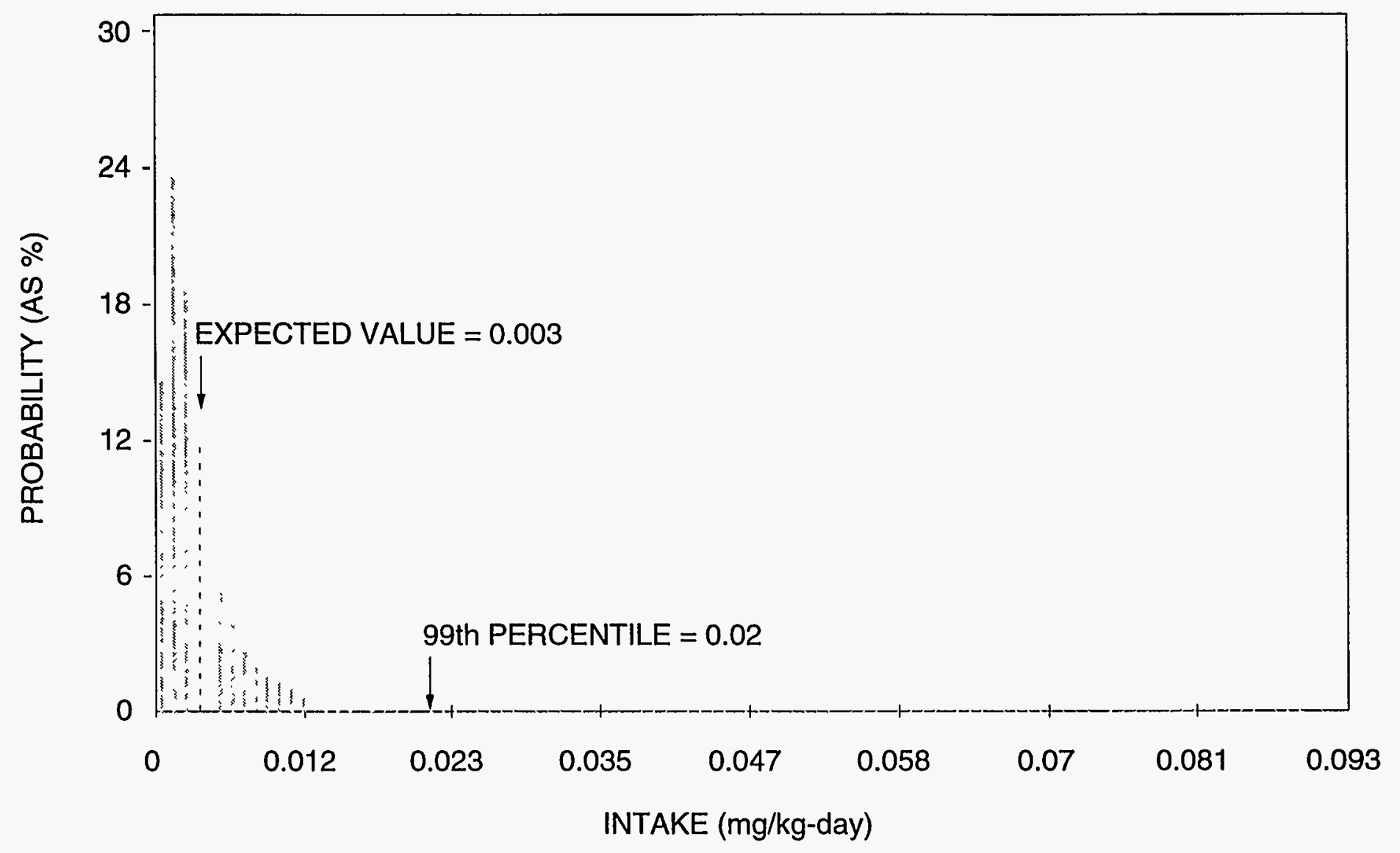

NOTE: AVERAGE POTENTIAL EXPOSURE IS $0.003 \mathrm{mg}$ MOLYBDENUM $/ \mathrm{kg}$ BODY WEIGHT PER DAY. EXPOSURES FOR CHILDREN ARE MODELED BECAUSE THEIR INTAKE/kg BODY WEIGHT IS GREATEST AND NO SENSITIVE POPULATION HAS BEEN IDENTIFIED.

FIGURE 4.15

PROBABILITY DISTRIBUTION OF MOLYBDENUM INTAKES GREEN RIVER, UTAH, SITE 


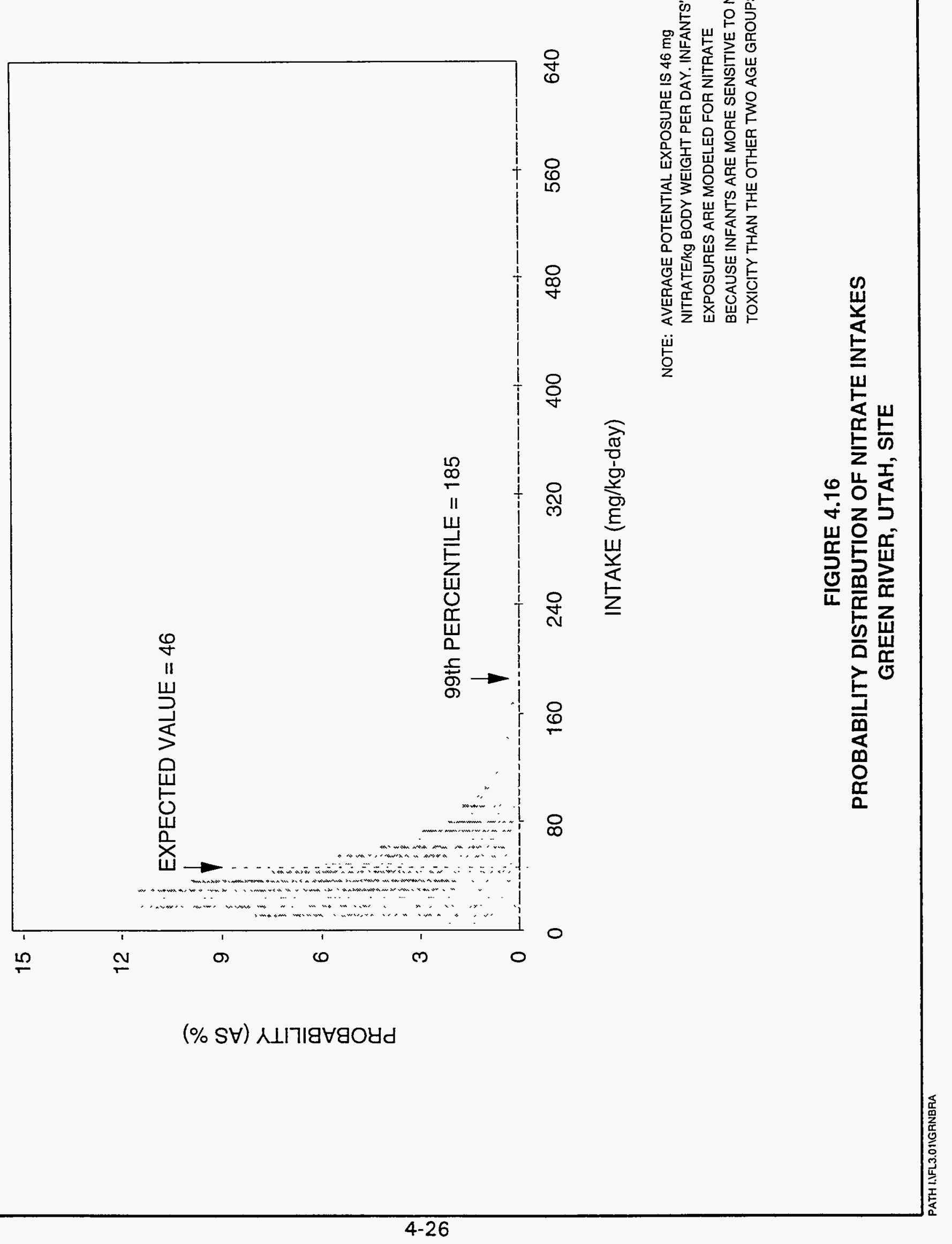




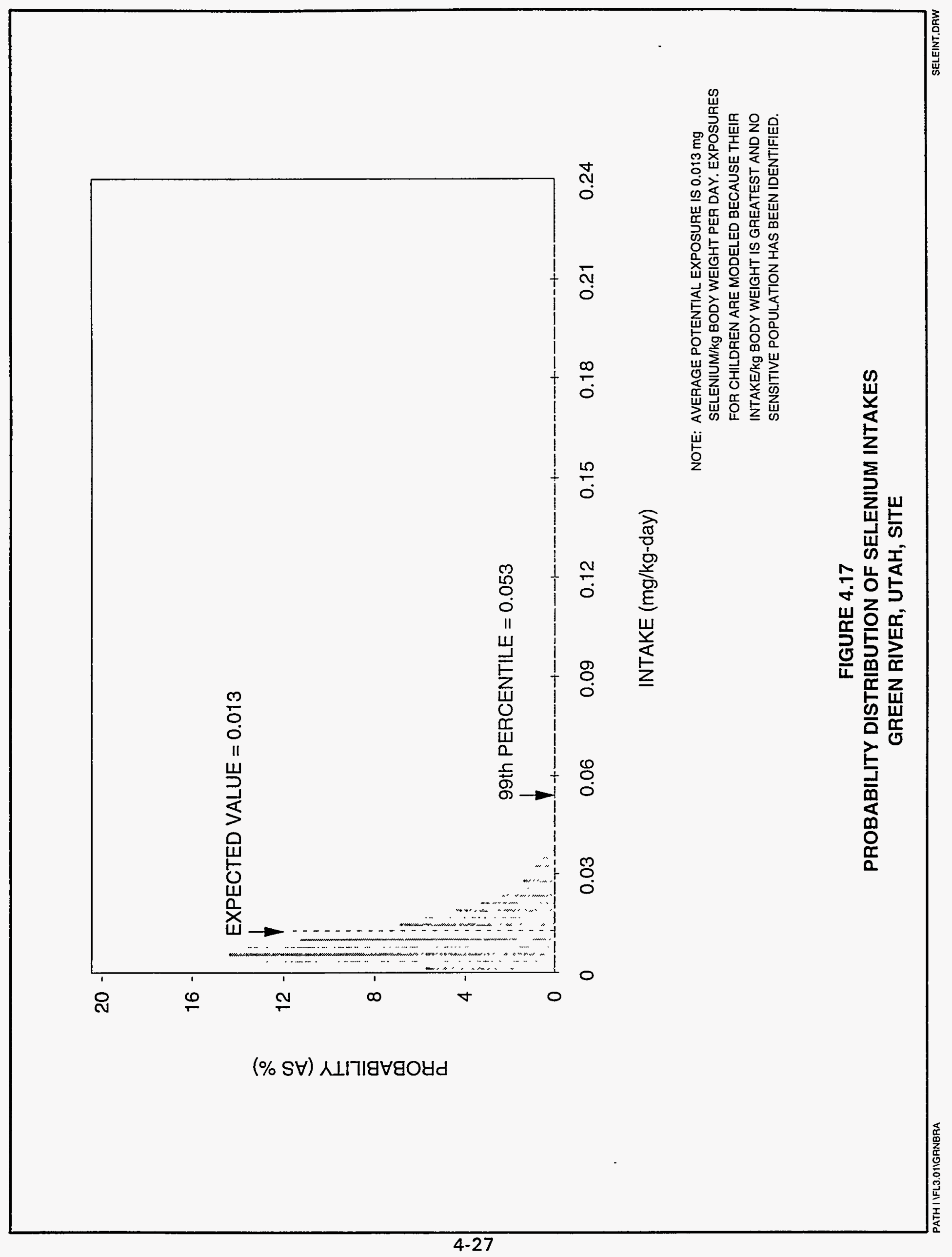




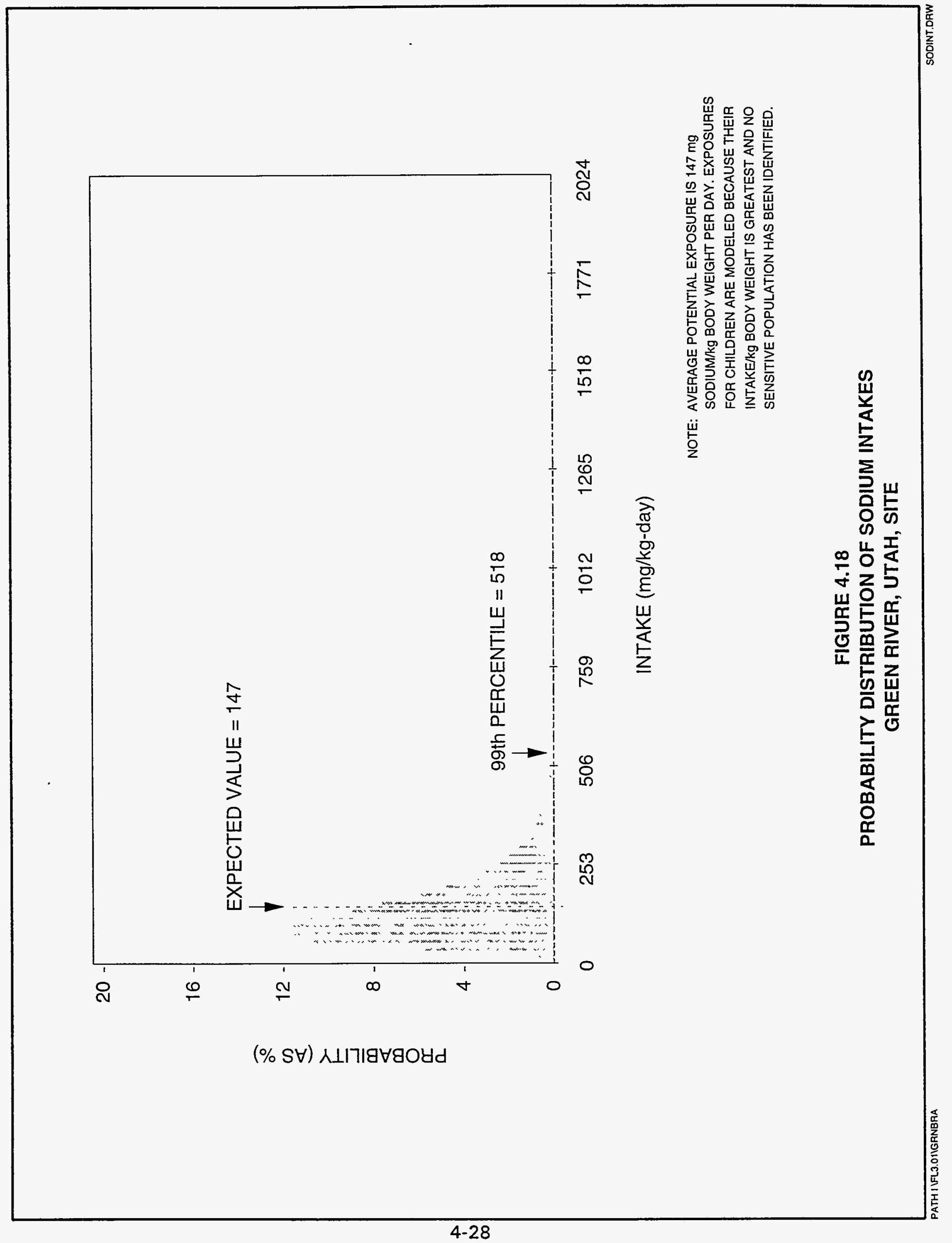




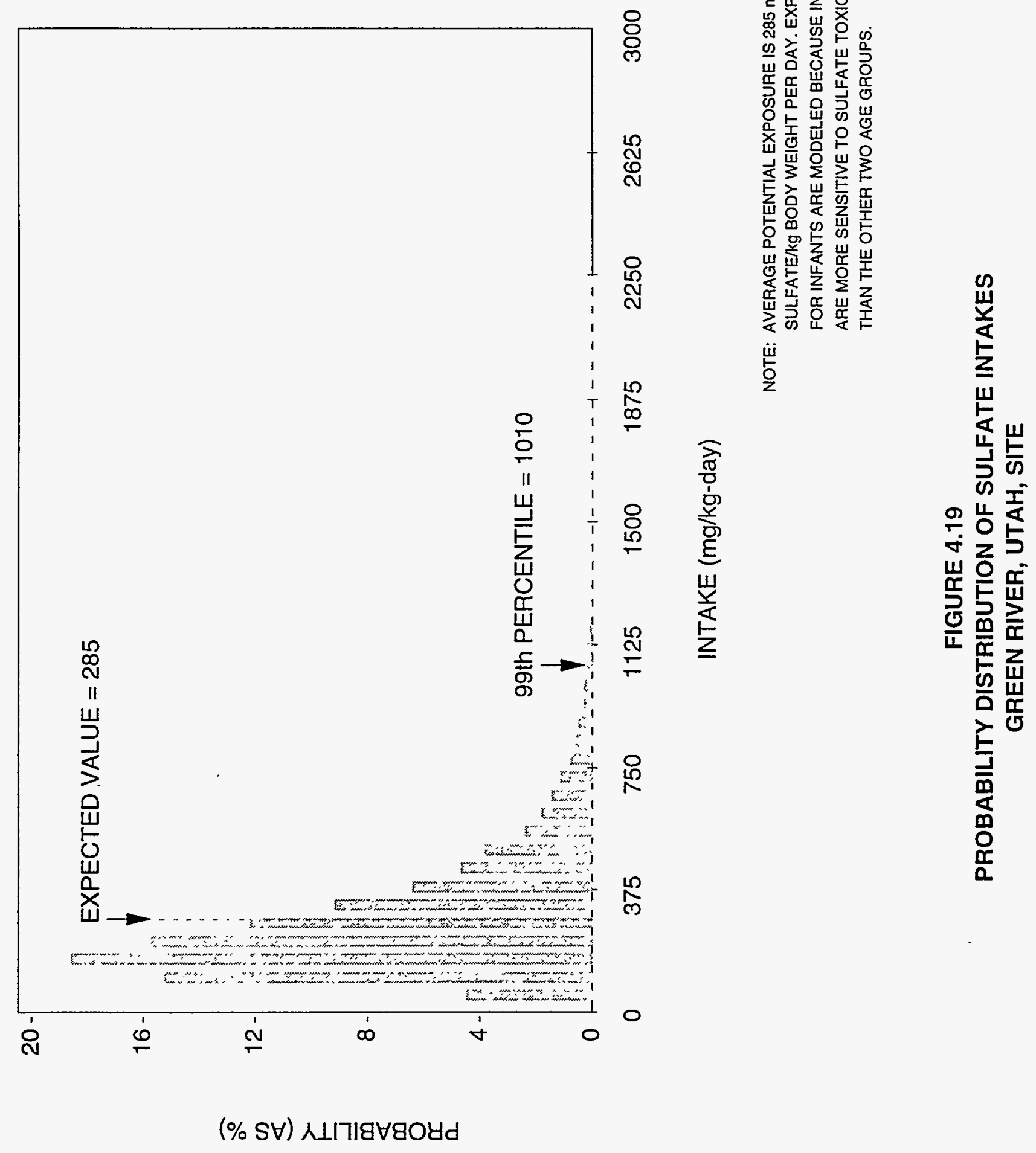




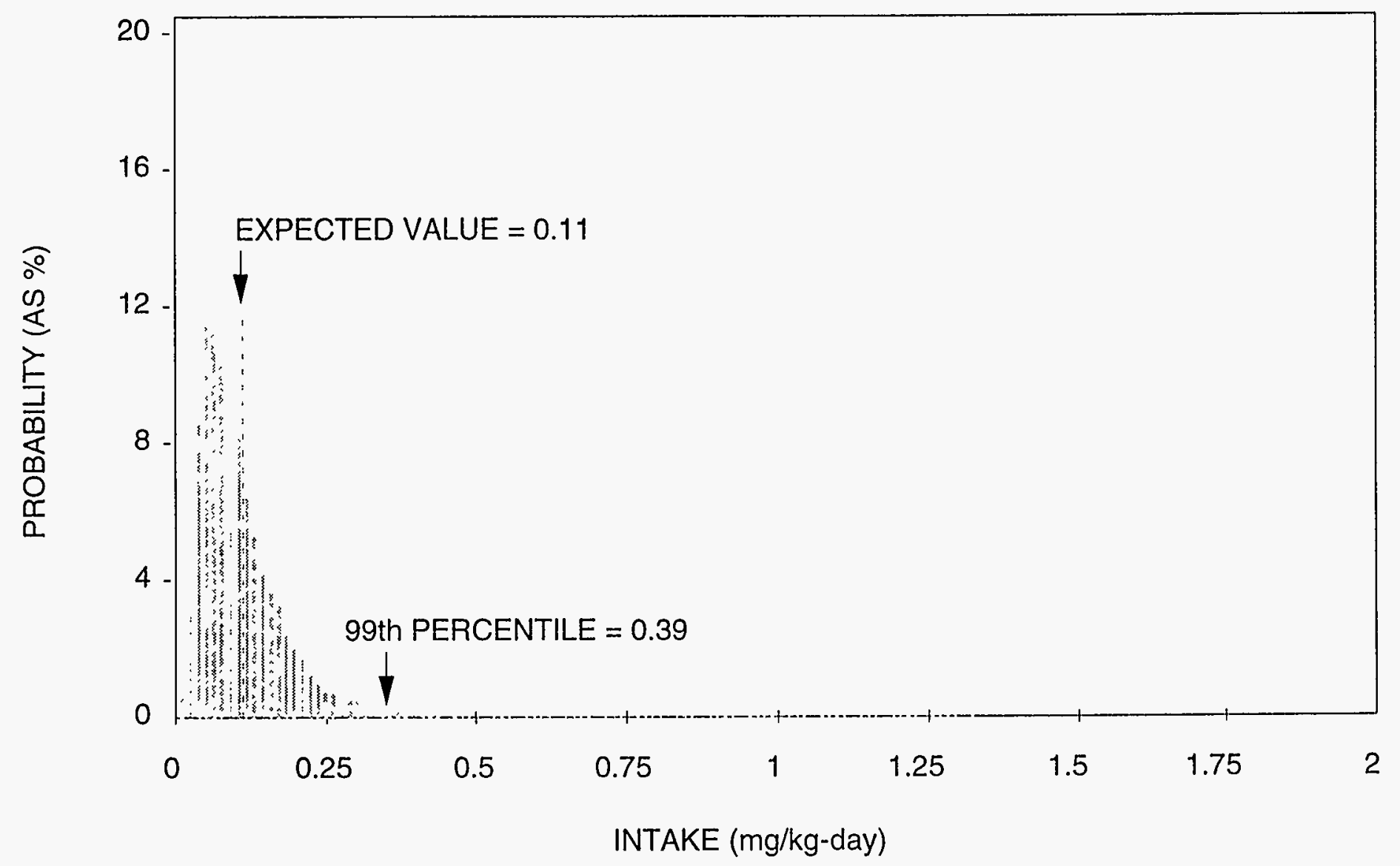

NOTE: AVERAGE POTENTIAL EXPOSURE IS $0.11 \mathrm{mg}$ URANIUM $/ \mathrm{kg}$ BODY WEIGHT PER DAY. EXPOSURES FOR CHILDREN ARE MODELED BECAUSE THEIR INTAKE/kg BODY WEIGHT IS GREATEST AND NO SENSITIVE POPULATION HAS BEEN IDENTIFIED.

FIGURE 4.20

PROBABILITY DISTRIBUTION OF URANIUM INTAKES GREEN RIVER, UTAH, SITE 


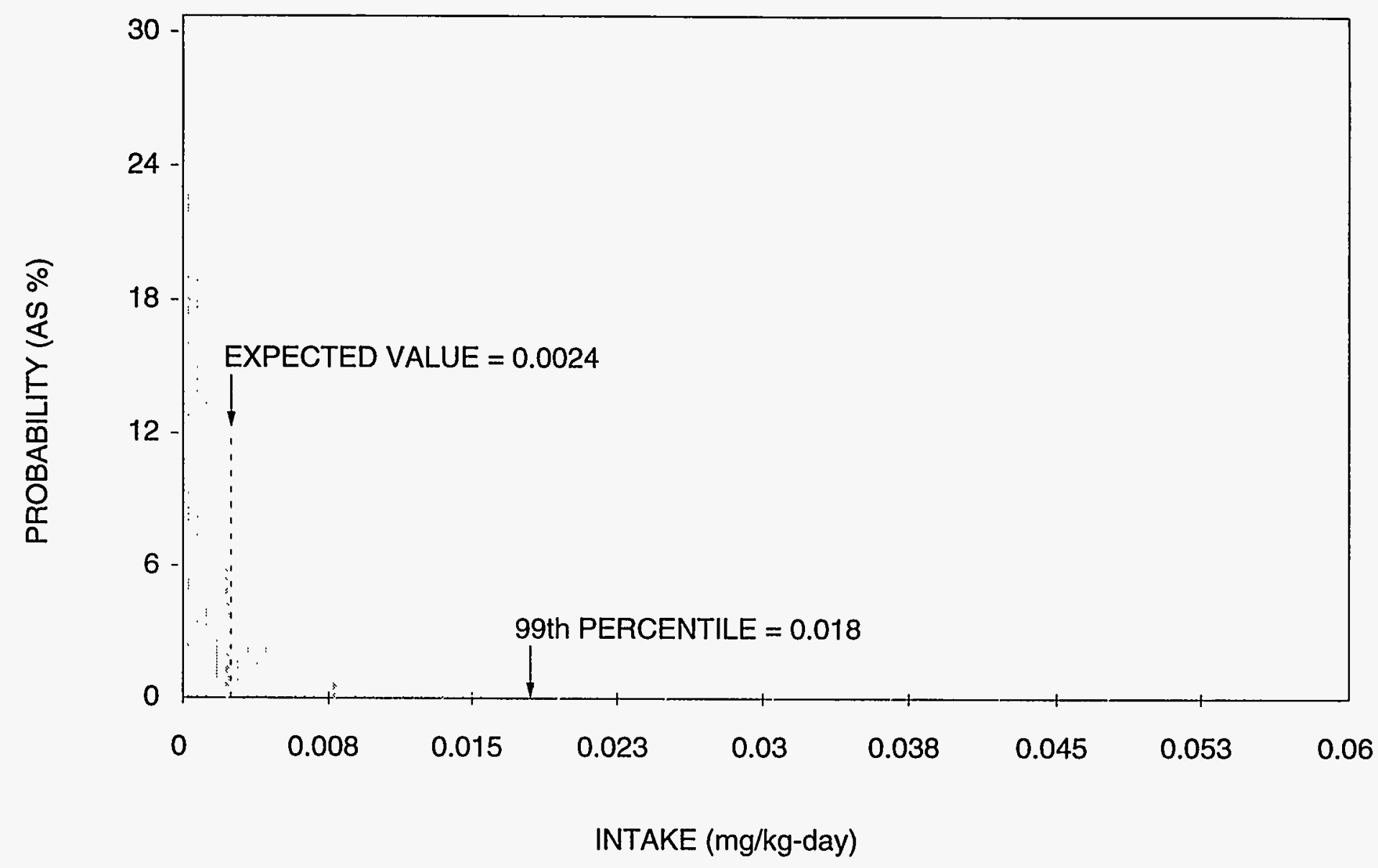

NOTE: AVERAGE POTENTIAL EXPOSURE IS $0.0024 \mathrm{mg}$ VANADIUM $/ \mathrm{kg}$ BODY WEIGHT PER DAY. EXPOSURES FOR CHILDREN ARE MODELED BECAUSE THEIR INTAKE/kg BODY WEIGHT IS GREATEST AND NO SENSITIVE POPULATION HAS BEEN IDENTIFIED.

FIGURE 4.21

PROBABILITY DISTRIBUTION OF VANADIUM INTAKES GREEN RIVER, UTAH, SITE 


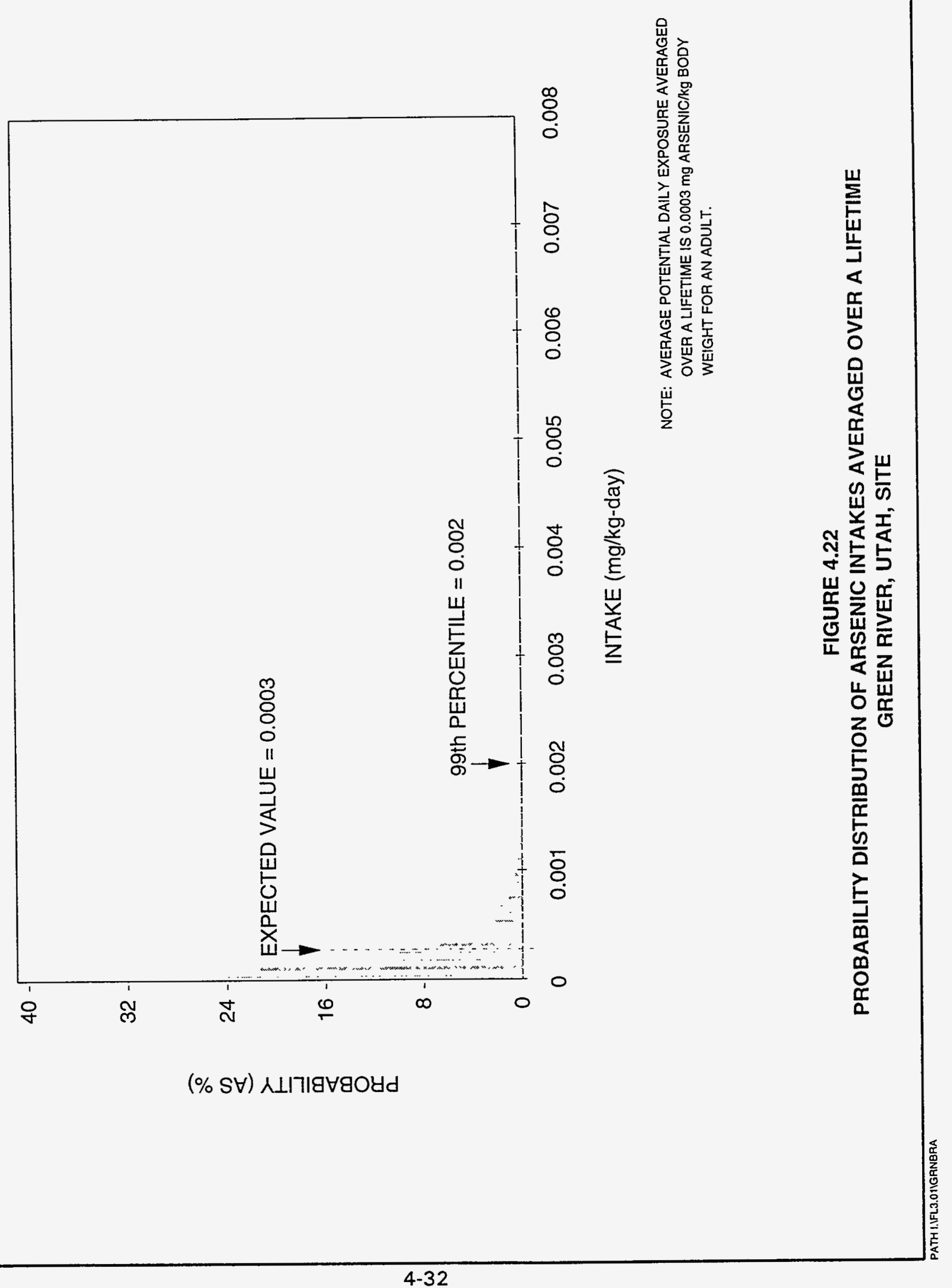




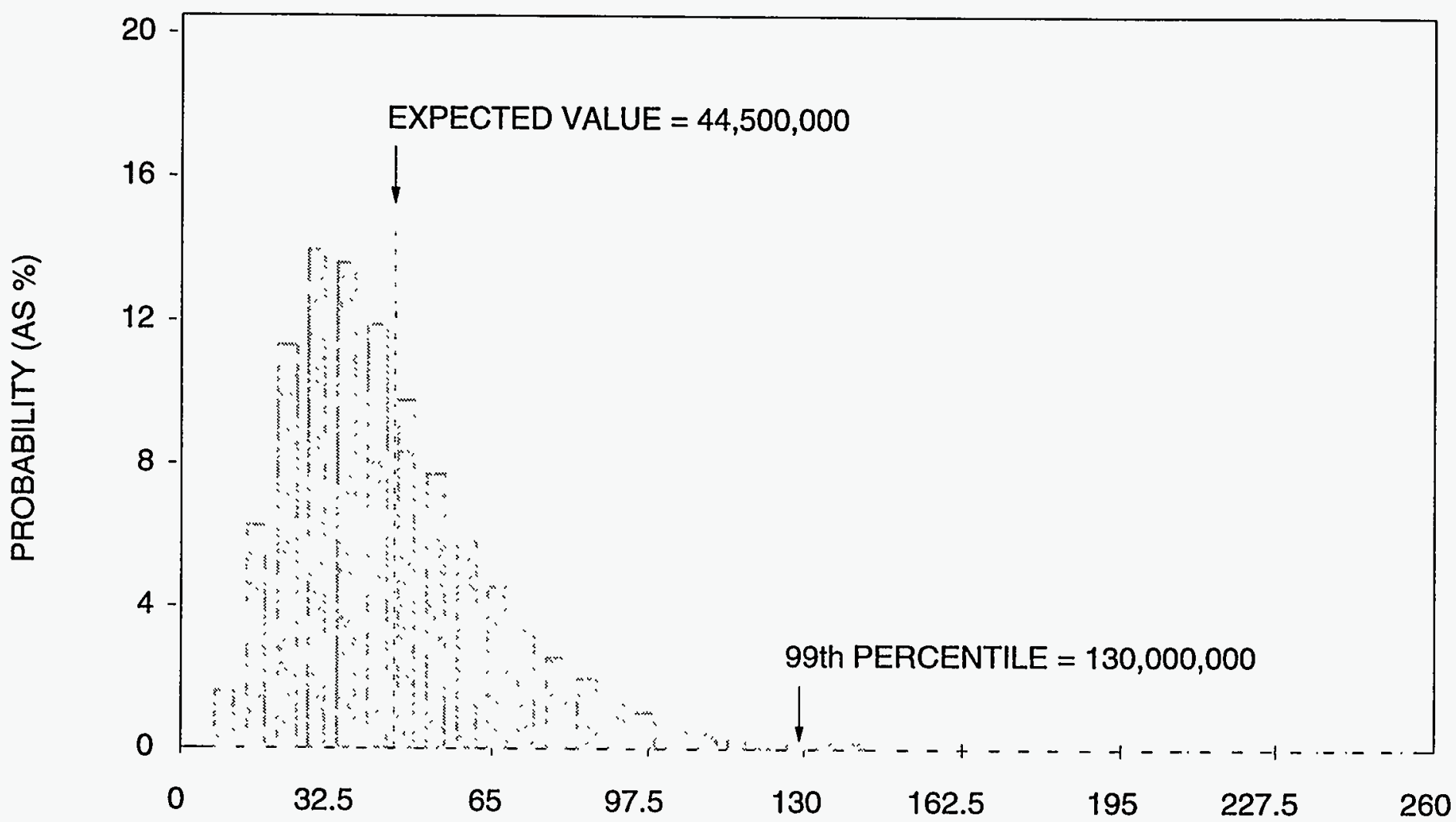

INTAKE (millions of pCi/lifetime)

NOTES:

1. CONCENTRATION DISTRIBUTION IS BASED ON MAXIMUM OBSERVED CONCENTRATION OF URANIUM AT $3.11 \mathrm{mg} / L$ AND THE ASSUMPTION THAT $1 \mathrm{mg}$ EQUALS $686 \mathrm{pCi}$.

2. AVERAGE POTENTIAL EXPOSURE IS $44,500,000 \mathrm{pCi}$ URANIUM -234 AND URANIUM -238 PER LIFETIME FOR AN ADULT.

3. EXPOSURE IS ASSUMED TO BE HALF U-234 AND HALF U-238.

FIGURE 4.23

PROBABILITY DISTRIBUTION OF LIFETIME URANIUM INTAKES GREEN RIVER, UTAH, SITE 


\subsection{EXPOSURE ASSESSMENT UNCERTAINTIES}

A number of potential sources of error may arise in all phases of the exposure assessment, including the following:

- Uncertainties resulting from a lack of thorough environmental sampling data (ground water and surface water), which could lead to an underestimate or overestimate in the exposure analysis.

- Uncertainties arising from the assumption that the ground water contaminant source term at the site has reached a steady state and that contaminant concentrations at the exposure point will remain constant for chronic periods of exposure (generally longer than 7 years). Because the major source of contamination (tailings) at the Green River site has been removed, the assumption of a constant source may lead to an overestimation of risk. However, because most of the monitor wells used in this assessment were decommissioned during surface remediation, present contaminant concentrations are not known. Therefore, the net effect on exposure estimates of these uncertainties cannot be predicted at this time.

- Uncertainties associated with the model used to estimate uptake of contaminants into plants in the irrigated garden produce pathway. Under the site conditions, plant uptake factors could vary substantially from the default literature estimates. As with environmental sampling, the net effect on risk estimates of this uncertainty cannot be predicted.

- Uncertainties associated with the relationship of an applied dose (used here) and absorbed dose or effective dose for dermal absorption. The assumption that metals are absorbed across intact skin at the same rate as water is likely to overestimate any potential contribution of exposure from dermal absorption.

- Uncertainties associated with differing sensitivities of subpopulations such as diabetics and the elderly.

Despite these uncertainties, the use of probability distributions that incorporate all definable sources of variability should provide a representative picture of the potential range of exposures. 


\subsection{TOXICITY ASSESSMENT}

Several contaminants that could adversely affect health and the environment have been detected in ground water at the site. This section summarizes the toxicological effects of the chemical contaminants and the carcinogenic potentials of arsenic and the radionuclides.

The following source materials were used in developing these toxicological profiles: when available, the EPA's Integrated Risk Information System (IRIS); the Agency for Toxic Substances and Disease Registry (ATSDR) toxicological profiles published by the Department of Health and Human Services (DHHS); the Handbook on the Toxicology of Metals (Friberg et al., 1986); and peer-reviewed scientific literature as cited when these review documents were not available. By basing toxicity information on the standardized review documents cited above, the evaluation of risks at UMTRA Project sites should be consistent with evaluations at other sites.

The toxicity profiles presented here focus on drinking water source material in humans whenever available. Animal information is included only if human data are not available. Animal information on the toxicity range graphs is represented by widely spaced dotted lines. When uncertainty exists about the beginning or ending points of a range of exposures producing specific toxic effects, closely spaced dots will be used at the appropriate end of the line denoting range.

\subsection{CONTAMINANT TOXICITY SUMMARIES}

The following summaries address the basic toxicokinetics and toxicity of the contaminants of potential concern at the Green River site based on the screening discussed in Section 3.0. The contaminants of potential concern are arsenic, manganese, molybdenum, nitrate, selenium, sodium, sulfate, vanadium, and uranium and its decay products (radium-226, lead-210, polonium-210, and thorium-230). Although these contaminants have a wide range of toxic effects depending on the exposure levels, the following discussions will focus most heavily on toxic effects observed in the exposure range most relevant to contamination at this site.

\subsubsection{Arsenic}

\section{Absorption}

Arsenic is effectively absorbed through the gastrointestinal tract and via inhalation. Dermal absorption is negligible. In humans, approximately 80 percent of an ingested amount of dissolved inorganic trivalent (arsenite) or pentavalent arsenic (arsenate) is absorbed from the gastrointestinal tract (Pershagen and Vahter, 1979; Marafante and Vahter, 1987). 


\section{Tissue accumulation and clearance}

After absorption by the gastrointestinal tract, arsenic is transported via the blood to most tissues. In humans as well as in most animal species, exposure to either arsenite or arsenate leads to an initial accumulation in the liver, kidneys, and lungs. The clearance from these tissues is very rapid, and a long-term retention of arsenic is seen in organs rich in sulfhydryl-containing proteins, such as the hair, skin, squamous epithelium of the upper gastrointestinal tract, epididymis, thyroid, lens, and skeleton (Lindgren et al., 1982). Specific target tissue depends on the form of arsenic. Higher retention of arsenic occurs after exposure to trivalent arsenic than to the pentavalent form, and tissue distribution is altered (Webb, 1966; Casarett and Doull, 1991).

In humans and rats, inorganic arsenic passes through the placental barrier. It has also been demonstrated to enter both cow and human milk (Marcus and Rispin, 1988).

In the human body, where methylcobalamine acts as a major methyl group donor in the biotransformation process, inorganic arsenic is converted to methylated compounds. It has been demonstrated that the major site of arsenic methylation is the liver (Marcus and Rispin, 1988). Trivalent arsenic is the substrate for methylation, and pentavalent arsenic must be reduced to trivalent arsenic before methylation can occur. Dimethylarsenic acid is a major metabolite found in animals and humans. Methylation results in a detoxification of inorganic arsenic (about one order of magnitude per methyl group) and increases the rate of arsenic excretion from the body.

The major route of excretion following human exposure to inorganic arsenic is via the kidneys (Ishinishi et al., 1986). Only a few percent is excreted in feces. The rate of excretion in urine varies depending on the chemical form of arsenic, the duration of exposure, and the species exposed. In humans exposed to a single low dose of arsenite, about 35 percent was excreted in urine over a period of 48 hours (Buchet et al., 1980, 1981). In the case of continuous human intake over a few days, 60 to 70 percent of the daily dose is excreted in urine (Buchet et al., 1981). Following exposure to arsenate, the limited human data available indicate a rate of excretion similar to that of arsenite. Other, less important routes of elimination of inorganic arsenic include skin, hair, nails, and sweat.

After oral intake of radiolabeled pentavalent arsenic, 66 percent was excreted with a half-time of 2.1 days, 30 percent with a half-time of 9.5 days, and 3.7 percent with a half-time of 38 days (Marcus and Rispin, 1988).

\section{Environmental sources of arsenic}

Arsenic is ubiquitous in nature in both inorganic and organic compounds. Water is the major means of arsenic transport under natural conditions. In oxygenated 
water, arsenic occurs in a pentavalent form; under reducing conditions, the trivalent form predominates.

As a result of arsenic's widespread occurrence, the general human population is exposed to it primarily from drinking water and foodstuffs. Certain target groups are exposed to arsenic from industrial and agricultural uses. Medicinal use has also been a significant means of human exposure.

Drinking water usually contains a few micrograms of arsenic, predominantly as inorganic salts in the trivalent and pentavalent states (WHO, 1981). However, concentrations of up to $1.1 \mathrm{mg} / \mathrm{L}$ in drinking water have been reported in Chile, Argentina, Taiwan, the United States, and the United Kingdom (WHO, 1981).

Certain foodstuffs contain appreciable amounts of arsenic. The concentration of arsenic in fish and seafood, particularly shellfish, is generally one or two orders of magnitude higher than in other foods. Wine and mineral waters can contain several hundred micrograms of arsenic per liter (Crecelius, 1977; WHO, 1981).

\section{Toxicity of arsenic}

Levels of exposure associated with acute arsenic toxicity vary with the valency form of the element. Trivalent arsenicals (arsenites) are generally more toxic than pentavalent (arsenates) (Morrison et al., 1989), and inorganic arsenic compounds are more toxic than organic (Shannon and Strayer, 1989). Based on geochemical models for the Green River site, arsenic exists primarily in the pentavalent form in ground water (Table 3.5). For arsenic trioxide, the reported estimated acute oral lethal dose in humans ranges from 70 to $300 \mathrm{mg}$ (1 to $4 \mathrm{mg} / \mathrm{kg}$ ) (EPA, 1984). Acute exposure to inorganic arsenic compounds may lead to a severe inflammation of the gastrointestinal tract, encephalopathy, and an acute renal failure after ingestion.

Increasing chronic oral ingestion doses of arsenic progressively produce systemic effects including 1) arterial thickening in children and adults $(0.02 \mathrm{mg} / \mathrm{kg}$-day); 2) neurological symptoms, including peripheral neuropathy $(0.04 \mathrm{mg} / \mathrm{kg}$-day); 3) fibrosis of the liver $(0.05 \mathrm{mg} / \mathrm{kg}$-day); and 4) cirrhosis of the liver $(0.08 \mathrm{mg} / \mathrm{kg}$-day) (DHHS, 1993).

Chronic arsenic intoxications result from exposure to even small doses of arsenic over a long period of time. These intoxications are frequently caused by arsenic content in drinking water and in food. Changes of the skin leading to skin cancer are commonly seen in populations exposed to high concentrations of arsenic in drinking water. Endemic arsenic poisoning is seen in Cordoba, Argentina, where the concentration of arsenic in drinking water ranges from 0.9 to $3.4 \mathrm{mg} / \mathrm{L}$ (equivalent to 0.026 to $0.097 \mathrm{mg} / \mathrm{kg}$-day). Certain areas in Taiwan also have high natural arsenic concentrations in drinking water that cause blackfoot disease (a peripheral extremity vascular disorder resulting in gangrene). A dose-response relationship between the incidence of blackfoot 
disease and the duration of exposure to arsenic has been documented (Tseng, 1977).

Hyperpigmentation, hyperkeratoses, and skin cancer with prevalence of 7.1 percent, 18.4 percent, and 1.1 percent, respectively, were reported in Taiwanese studies of more than 40,000 people exposed to arsenic in drinking water at daily intakes ranging from 1.4 to $6.3 \mathrm{mg}$.

Teratogenic effects of arsenic compounds administered intravenously or intraperitoneally at high doses have been demonstrated in laboratory animals only (Ferm, 1971; Hood, 1972; EPA, 1984). Teratogenic effects, also referred to as birth defects, are defined as effects resulting in structural or functional anomalies in live offspring.

Certain characteristics of exposed human populations may influence arsenic toxicity at high exposure levels. Genetic dispositions (rapid versus poor acetylators) and protein-deficient diet may decrease the methylation of arsenic. This can result in an increased deposition of the element in the target organs (e.g., lung or skin).

The EPA has classified inorganic arsenic as a Group $A$ (human) carcinogen (EPA, 1994a), based on the occurrence of increased lung cancer mortality (in populations exposed primarily via inhalation) and of increased skin cancer prevalence (in populations exposed by consuming drinking water containing high concentrations of arsenic). The current slope factor (SF) for oral exposure to arsenic is given in Table 5.1. This SF is currently under review by the EPA with respect to recent data suggesting arsenic ingestion may result in increased cancers in internal organs as well as skin cancers. The health effects from exposure to arsenic as a function of dose are summarized in Figure 5.1.

\subsubsection{Manganese}

\section{Absorption}

Following ingestion, manganese absorption is homeostatically controlled: the rate of absorption depends on both the amount ingested and tissue levels of manganese. For adult humans, approximately 3 to 4 percent of dietary manganese is absorbed (Saric, 1986). Manganese can be absorbed following exposure by inhalation, ingestion, and dermal contact. In humans, available data indicate that only 3 percent of an ingested dose of manganese chloride is absorbed (Mena et al., 1969). The rate of absorption is influenced by iron and other metals. In states of iron deficiency, manganese is actively absorbed from the intestine. Individuals with anemia can absorb more than twice the percentage of an ingested dose. However, in states of excess iron, absorption of manganese is by diffusion only (Saric, 1986). High levels of dietary calcium and phosphorus have been shown to increase the requirements for manganese in several species (Lönnerdal et al., 1987). 


\begin{tabular}{|c|c|c|c|c|}
\hline Parameter & $\begin{array}{c}\text { Oral SF } \\
(\mathrm{pCi})^{-1},(\mathrm{mg} / \mathrm{kg} \text {-day })^{-1} \\
\end{array}$ & $\begin{array}{c}\text { Weight of evidence } \\
\text { classification }\end{array}$ & Type of cancer & SF basis/SF source \\
\hline Arsenic (inorganic) ${ }^{a}$ & $1.8 \mathrm{E}+0$ & A & Skin & Water/IRIS ${ }^{b}$ \\
\hline Lead-210 & 5.1E-10 & A & Bone & Water/HEASTC \\
\hline Polonium-210 & $1.5 \mathrm{E}-10$ & A & Liver, kidney, spleen & Water/HEAST \\
\hline Radium-226 & $1.2 \mathrm{E}-10$ & A & Bone & Water/HEAST \\
\hline Thorium-230 & $1.3 \mathrm{E}-11$ & A & Bone & Water/HEAST \\
\hline Uranium-238 & $1.6 \mathrm{E}-11$ & A & Note ${ }^{d}$ & Water/HEAST \\
\hline Uranium-234 & $1.6 \mathrm{E}-11$ & A & Note $^{d}$ & Water/HEAST \\
\hline
\end{tabular}

${ }^{\text {a }} \mathrm{SF}$ based on oral unit risk of $5 \times 10^{-5}$ (EPA, 1994a).

bEPA, 1994a.

CEPA, $1994 b$.

dNo human or animal studies have shown a definite association between oral exposure to uranium and development of cancer.

A - human carcinogen. 


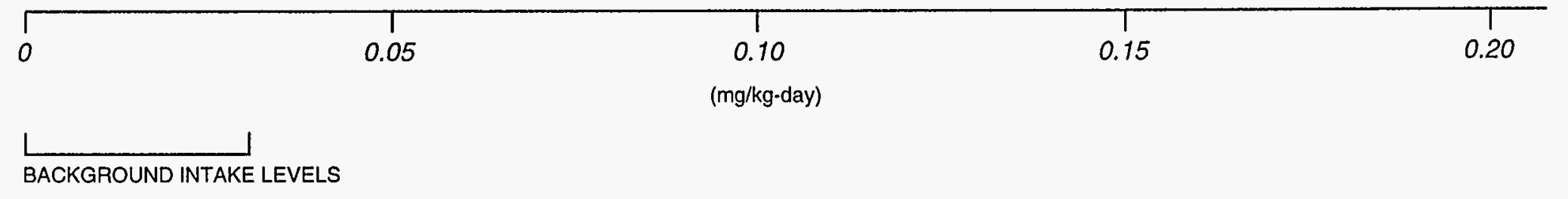

$\triangle$ ORAL REFERENCE DOSE $=0.0003 \mathrm{mg} / \mathrm{kg} \cdot$ day

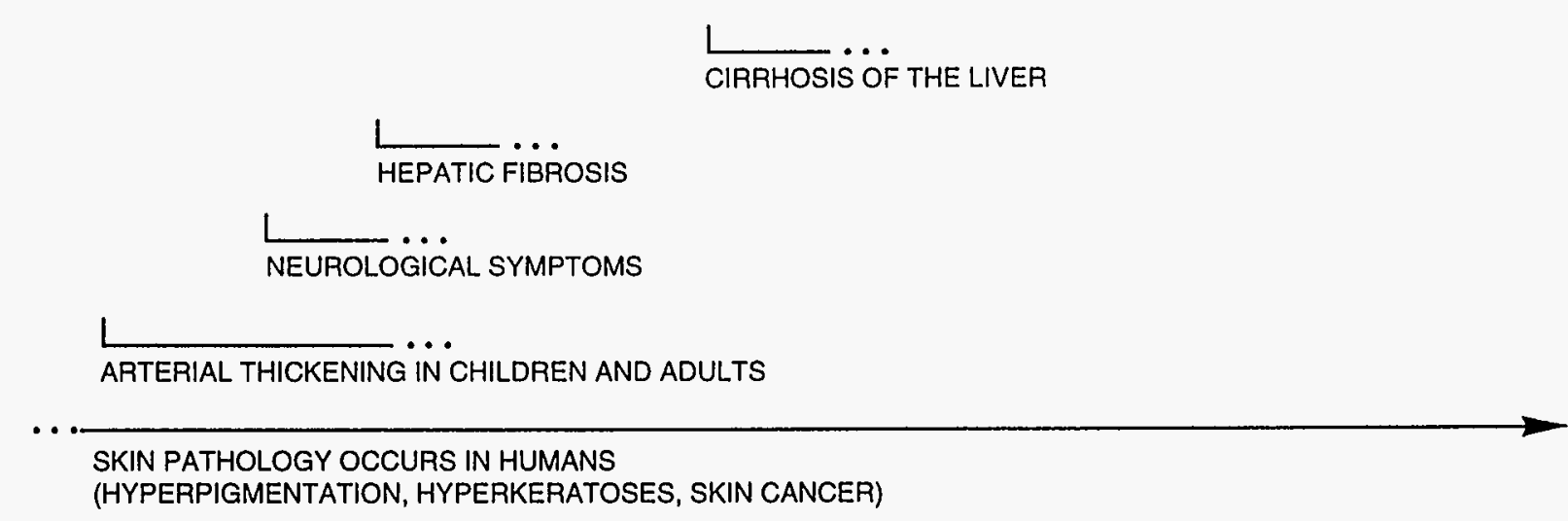

FIGURE 5.1 ARSENIC TOXICITY RANGES 


\section{Tissue accumulation and clearance}

Manganese is widely distributed throughout the body. Highest concentrations are found in the liver and kidney and, to a lesser extent, the hair. The biological half-time in humans is 2 to 5 weeks, depending on body stores. Manganese readily crosses the blood-brain barrier and is more slowly cleared from brain than from other tissues (Goyer, 1991). Normal concentrations in the brain are low, but the half-time in the brain is longer and the metal may accumulate in the brain with excessive absorption (National Research Council, 1973).

Absorbed manganese is rapidly cleared from the blood and concentrates in mitochondria. Initial concentrations are greatest in the liver. Manganese penetrates the placental barrier in all species and is more uniformly distributed throughout the fetus than in adult tissues. It is secreted into milk.

Absorbed manganese is almost totally secreted in bile and reabsorbed from the intestine as necessary to maintain body levels. At excessive exposure levels, other gastrointestinal routes may participate. Excess manganese is eliminated in the feces; urinary excretion is negligible (Goyer, 1991; Saric, 1986).

\section{Environmental sources of manganese}

On the whole, food constitutes the major source of manganese intake for humans. The highest manganese concentrations are found in plants, especially wheat and rice. Drinking water generally contains less than $0.1 \mathrm{mg} / \mathrm{L}$. Manganese levels in soil range from 1 to $7000 \mathrm{mg} / \mathrm{kg}$, with an average of 600 to $900 \mathrm{mg} / \mathrm{kg}$. Mining and natural geological background variation can contribute to this variability. Manganese bioaccumulates in marine mollusks up to 12,000 -fold, and there is evidence for toxic effects in plants (phytotoxicity) and plant bioaccumulation. The Illinois Institute for Environmental Quality has recommended a criterion of 1 to $2 \mathrm{mg} / \mathrm{kg}$ for manganese in soil and $200 \mathrm{mg} / \mathrm{kg}$ in plants (Saric, 1986).

Variations in manganese intake can be explained to a large extent by differences in nutritional habits. In populations with cereals and rice as main food sources, the intake will be higher compared to areas where meat and dairy products make up a larger part of the diet. The average daily intake has been estimated to be between 2.0 and $8.8 \mathrm{mg} /$ day $\{0.03$ and $0.13 \mathrm{mg} / \mathrm{kg}$-day) (EPA, 1994a). . but intakes as high as $12.4 \mathrm{mg}$ (about $0.2 \mathrm{mg} / \mathrm{kg}$-day) have been reported in countries with high cereal intake (Saric, 1986).

Drinking water generally results in an intake of less than $0.2 \mathrm{mg}$ $(0.003 \mathrm{mg} / \mathrm{kg}$-day), although some mineral waters can increase this amount by more than three-fold (Saric, 1986). One study from Greece reported drinking water concentrations of manganese in excess of $2 \mathrm{mg} / \mathrm{L}$, which would result in daily intakes in the range of 0.06 to $0.07 \mathrm{mg} / \mathrm{kg}$-day (EPA, 1994a). 


\section{Toxicity of manganese}

Manganese is an essential nutrient. Estimated safe and adequate daily dietary intakes for adults range from 0.03 to $0.07 \mathrm{mg} / \mathrm{kg}$-day (Saric, 1986). The EPA no-observed-adverse-effect level (NOAEL) for drinking water is set at $0.005 \mathrm{mg} / \mathrm{kg}$-day, while the lowest-observed-adverse-effect level (LOAEL) for drinking water sources is $0.06 \mathrm{mg} / \mathrm{kg}$-day (EPA, 1994a). The EPA RfD for drinking water is $0.005 \mathrm{mg} / \mathrm{kg}$-day. The RfD for food ingestion is $0.14 \mathrm{mg} / \mathrm{kg}$ day. There is some indication that manganese in drinking water is potentially more bioavailable (i.e., more readily absorbed) than manganese in dietary food sources. This would result in toxic effects with lower ingested doses of manganese in drinking water than in food (EPA, 1994a).

Inhalation of manganese in industrial settings has provided the largest source of data on chronic manganese toxicity. These data indicate that excess manganese can result in a central nervous system disorder consisting of irritability, difficulty in walking, speech disturbances, and compulsive behavior that may include running, fighting, and singing. With continued exposure, this condition can progress to a mask-like face, retropulsion or propulsion, and a Parkinson-like syndrome. The condition reverses slowly with removal of manganese exposure. Metal chelating agents are ineffective in treatment, but L-dopa has been effective in treatment (Goyer, 1991), suggesting that manganese produces functional deficit in the central nervous system.

Limited information is available on the effects of manganese ingestion. Because effects from drinking water seem to differ from those from food sources, only studies on water consumption will be considered here. A Japanese study of 25 people drinking well water with manganese concentrations of $14 \mathrm{mg} / \mathrm{L}$ $(0.4 \mathrm{mg} / \mathrm{kg}$-day estimated intake) reported symptoms of intoxication, including a mask-like face, muscle rigidity and tremors, and mental disturbances. There were two cases ( 8 percent) of death among intoxicated people. A Greek study of over 4000 individuals drinking water with manganese concentrations varying from 0.081 to $2.3 \mathrm{mg} / \mathrm{L}$ (estimated intake at $2 \mathrm{~L} /$ day for a $70-\mathrm{kg}$ individual range from 0.002 to $0.07 \mathrm{mg} / \mathrm{kg}$-day) showed varying degrees of neurological effects in individuals drinking from 0.007 to $0.07 \mathrm{mg} / \mathrm{kg}$-day, but no effects in individuals drinking less than $0.005 \mathrm{mg} / \mathrm{kg}$-day (Kondakis et al., 1989).

The chemical form of manganese has complex effects on its toxicity. Although more soluble forms are more readily absorbed from the gastrointestinal tract, they also appear to be more rapidly cleared. Exposure to insoluble forms results in lower manganese absorption, but higher chronic tissue levels and therefore greater toxicity (EPA, 1994a). Only limited information is available on the effects of various forms of manganese.

Few data are available on manganese toxicity in infants, but it is likely that infants will be more susceptible to toxicity due to greater absorption and greater penetration into the central nervous system (EPA, 1994a; Saric, 1986). 
The toxicity of manganese is summarized in Figure 5.2.

\subsubsection{Molybdenum}

\section{Absorption}

Absorption of molybdenum in the gastrointestinal tract depends on the species of the metal. Both inorganic and hexavalent forms such as molybdenum trioxide, sodium molybdate, and ammonium molybdate are readily absorbed from both food and water, whereas molybdenite is not. Human absorption rates of 40 to 70 percent have been observed for molybdenum (Tipton et al., 1969; Robinson et al., 1973; Alexander et al., 1974).

\section{Tissue accumulation and clearance}

In humans, the highest concentrations of molybdenum occur in the liver, kidney, and adrenals (Casarett and Doull, 1991). With normal dietary intake. molybdenum levels in the body slowly increase until approximately age 20 , then begin to decline steadily. The principal route of excretion in humans is in the urine. Human studies indicate the biological half-life in humans is considerably longer than in animals and may be as long as 2 weeks (Rosoff and Spencer, 1964).

\section{Environmental sources of molybdenum}

Natural molybdenum occurs in combination with other metals, including uranium, lead, iron, cobalt, and calcium. Native soil concentrations can vary by as much as two orders of magnitude, from $0.1 \mathrm{mg} / \mathrm{kg}$ to $10 \mathrm{mg} / \mathrm{kg}$, leading to large variations in molybdenum concentrations in plant materials. Natural concentrations in ground water have been reported from $0.00011 \mathrm{mg} / \mathrm{L}$ to $0.0062 \mathrm{mg} / \mathrm{L}$. Human dietary intake of molybdenum has been estimated at 0.05 to $0.24 \mathrm{mg} / \mathrm{day}(0.0007$ to $0.003 \mathrm{mg} / \mathrm{kg}$-day). The contribution of drinking water is estimated to range from 0 percent to 95 percent. The nutritional range of intake for molybdenum is from 0.0015 to 0.0054 $\mathrm{mg} / \mathrm{kg}$-day. No symptoms of molybdenum deficiency have been reported in humans. Nonetheless, molybdenum is an essential trace element that functions as a necessary constituent of several enzymes, including xanthine oxidase (which is involved in the metabolism of uric acid) and nitrate reductase (Friberg et al., 1986).

\section{Toxicity of molybdenum}

Acute toxic effects of molybdenum have not been reported. No adverse health effects have been reported with chronic intake of less than $0.008 \mathrm{mg} / \mathrm{kg}$-day of molybdenum. The primary toxicity of molybdenum is related to its interactions with copper and sulfur, leading to altered excretion patterns for these elements. Increased levels of molybdenum also increase the levels of xanthine oxidase. 


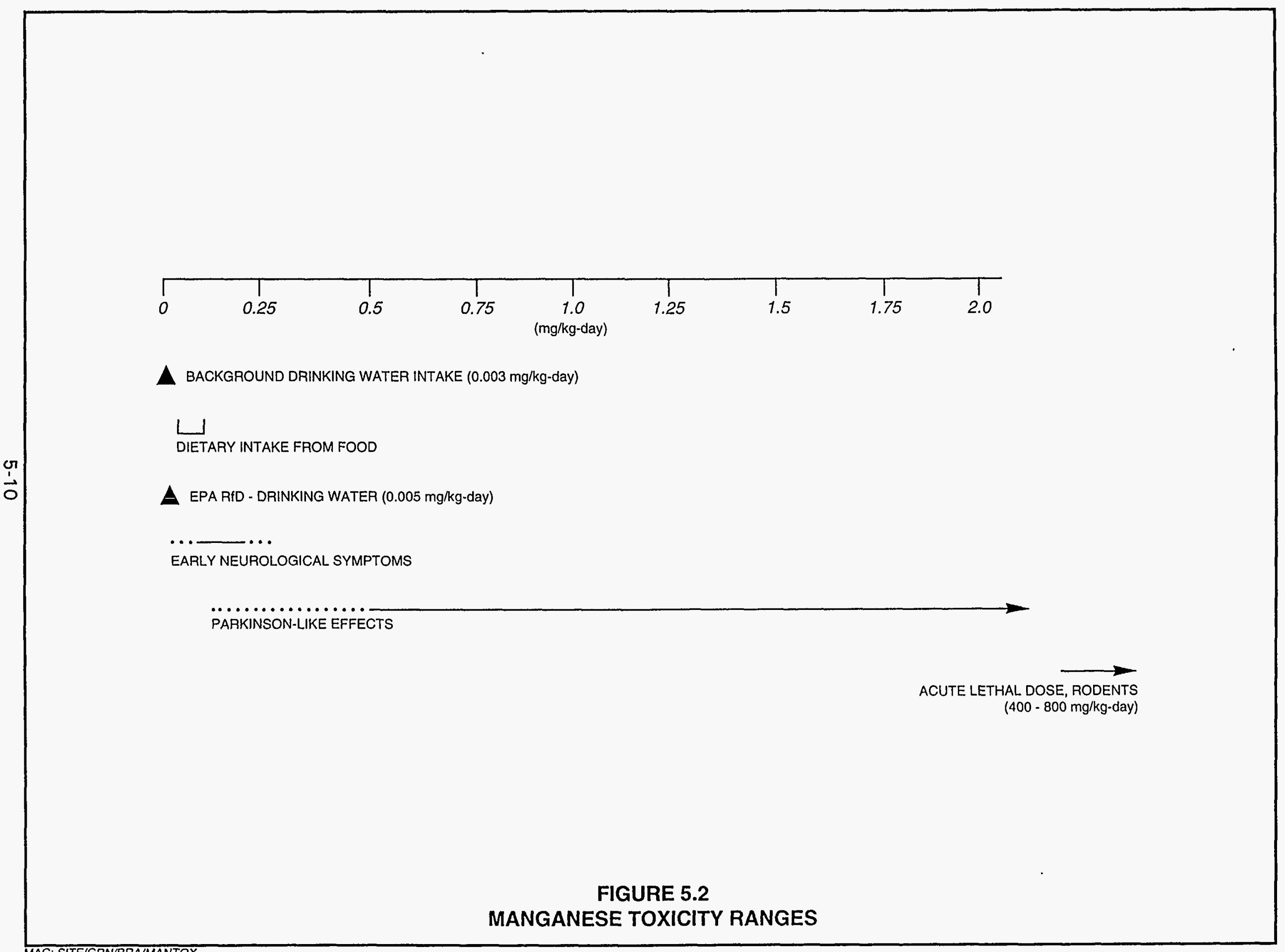


which is responsible for the production of uric acid. High levels of uric acid can accumulate in joints and lead to symptoms of gout and other joint disorders.

Intake of 0.008 to $0.022 \mathrm{mg} / \mathrm{kg}$-day of molybdenum can produce mineral imbalance as a result of increased copper excretion. Excretion of copper has been reported to double with molybdenum intakes at the upper end of this range. Copper is an essential nutrient important in many metabolic pathways, including the synthesis and function of hemoglobin. A copper deficiency resulting from excess excretion will impair the oxygen-carrying capacity of the blood, and severe copper deficiencies can lead to hypochromic microcytic anemia. In humans, gout-like symptoms and joint deformities have been reported in regions of Russia where elevated soil concentrations of molybdenum and subsequent increased molybdenum concentrations in food would lead to molybdenum intakes in the range of 0.14 to $0.21 \mathrm{mg} / \mathrm{kg}$-day. The health effects of molybdenum are summarized in Figure 5.3 as a function of dose.

\subsubsection{Nitrate}

\section{Absorption}

Ingested nitrate is converted in the gut to the toxic nitrite ion, which is readily absorbed. The conversion rate depends on both gut flora and $\mathrm{pH}$, with a more rapid conversion in a higher $\mathrm{pH}$ environment. Infants have a higher gut $\mathrm{pH}$, which is more conducive to growth of bacteria. Therefore, the combination of an alkaline environment and increased bacterial conversion increases the production of nitrite from nitrate in infants, resulting in higher blood nitrite levels for a given dose of nitrate. In healthy adults, nitrates are rapidly absorbed from the upper intestine. This rapid absorption reduces the contact time with gut flora, thereby reducing the conversion to nitrite and the resultant toxicity.

\section{Tissue accumulation and clearance}

After absorption, the nitrite ion binds to hemoglobin in the blood and oxidizes it, thereby reducing the oxygen-carrying capacity of the blood and decreasing the rate of oxygen release. The oxidized hemoglobin is called methemoglobin and can be reduced back to normal hemoglobin enzymatically by methemoglobin reductase. Infants are more sensitive to these effects because of 1) the presence of fetal hemoglobin, which is more sensitive to oxidation by nitrite, and 2) lower activity of methemoglobin reductase, meaning the methemoglobin remains oxidized for a longer period. Certain individuals have a rare genetic deficiency in methemoglobin reductase and therefore exhibit higher levels of circulating methemoglobin. Although these individuals develop alternate metabolic pathways to maintain adequate levels of circulating hemoglobin in the normal state, exposure to high levels of nitrate can result in excessive levels of methemoglobin in these individuals. 


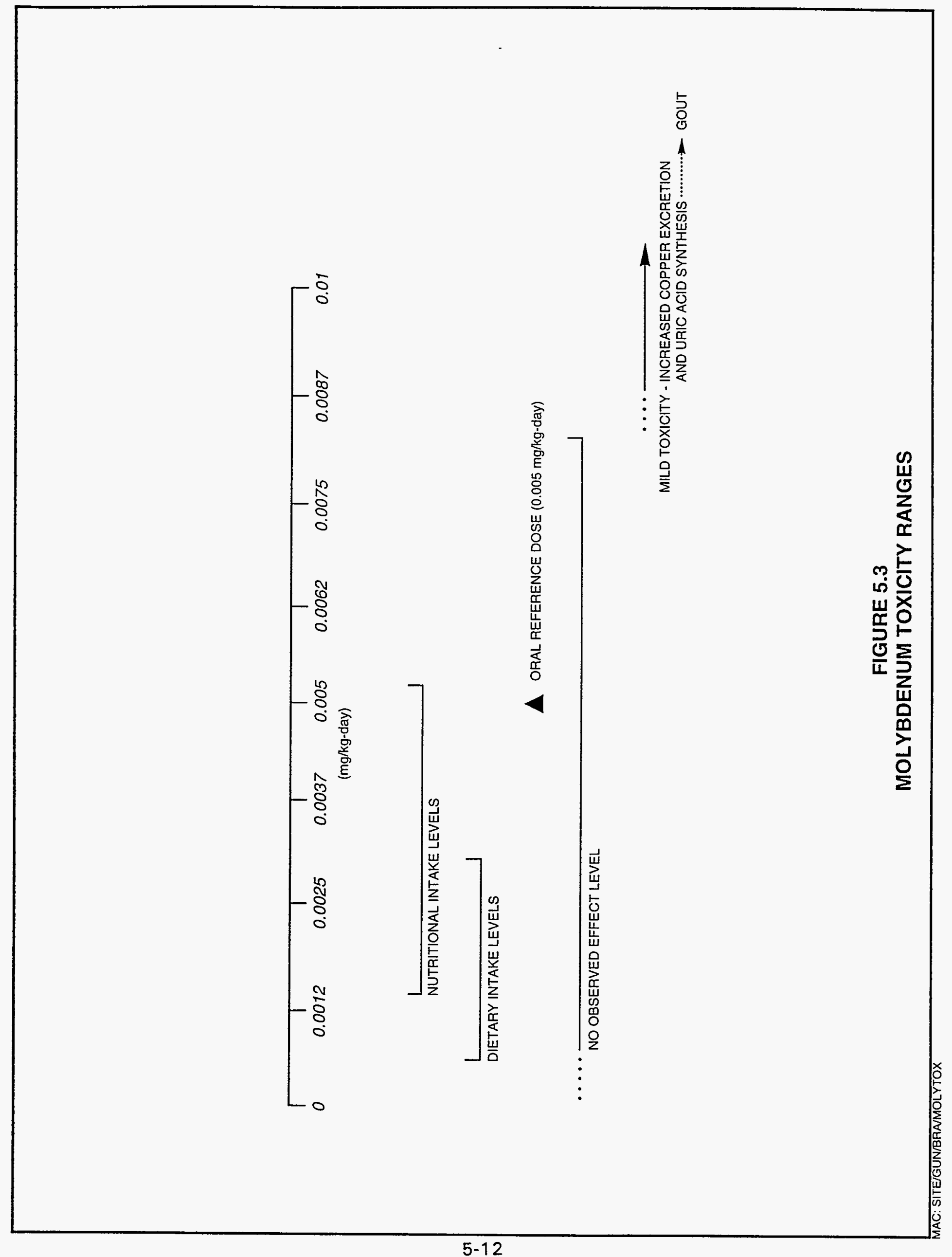


In healthy adults, the half-time for methemoglobin reductase conversion of methemoglobin back to hemoglobin is estimated to range from 6 to 24 hours for theoretical levels of methemoglobin in the 80-to 100-percent range (Bolyai et al., 1972).

\section{Environmental sources of nitrate}

Nitrates accumulate in soils from the application of fertilizers, human and animal waste, bacterial nitrogen fixation, mineral dissolution, and plant and animal tissue breakdown. These nitrates can filter through the soil into ground water. Concentrations of nitrate in well water have been reported to exceed $440 \mathrm{mg} / \mathrm{L}$, or 10 times the current regulatory levels (Lee, 1970).

Bioaccumulation of nitrates from soil and water to plants results in a wide range of nitrate concentrations in fresh fruits and vegetables, with levels as high as $2000 \mathrm{mg} / \mathrm{kg}$ reported in beets and $9000 \mathrm{mg} / \mathrm{kg}$ in radishes (Kamm et al., 1965; Smith, 1966). The accumulation of nitrates in plant material is increased by factors such as drought, high temperatures, cloudiness, and insect and herbicide damage to plants. Nitrates and nitrites are also used to preserve meats, especially corned or smoked products.

\section{Toxicity of nitrate}

The primary toxicity of nitrate is methemoglobinemia, which is a function of the balance between circulating levels of nitrite and methemoglobin reductase activity. A very high acute dose can produce the same toxicity as a lower dose that slowly increases the concentration of methemoglobin over time. Therefore, the acute and chronic toxicity of nitrate are summarized together. To allow easier comparisons between ingested doses of nitrate and ground water levels at Green River, dose ranges are presented in terms of nitrate intake. The reader should be aware that nitrate exposure levels are frequently converted to the nitrogen concentration in the nitrate by dividing the nitrate number by 4.4 . Therefore, $44 \mathrm{mg} / \mathrm{L}$ nitrate is equivalent to $10 \mathrm{mg} / \mathrm{L}$ nitrate-nitrogen.

Symptoms of methemoglobinemia can be correlated with the percentage of methemoglobin in the blood as follows: less than 10 percent methemoglobin produces no symptoms in individuals; more than 25 percent methemoglobin produces weakness, rapid pulse, and tachypnea (rapid breathing); more than 5.0 to 60 percent methemoglobin can be fatal (EPA, 1994a). These symptoms reflect the progressive decrease in the availability of oxygen. As explained above, infants are more sensitive to the production of methemoglobin and therefore are considered the most sensitive population. The route of exposure for infants is from contaminated water used for formula.

No symptoms of toxicity have been reported with nitrate intakes below $7 \mathrm{mg} / \mathrm{kg}$-day in infants. Mild symptoms such as weakness, rapid pulse, and rapid breathing occur with intakes from 7 to $30 \mathrm{mg} / \mathrm{kg}$-day. The severity of these symptoms increases as increased nitrate intake results in greater levels of 
methemoglobin and therefore a reduced availability of oxygen. Cyanosis, or a blue appearance to the skin, occurs, followed by unconsciousness as the availability of oxygen is further reduced. The lowest reported fatal dose of chronic nitrate is $35 \mathrm{mg} / \mathrm{kg}$-day for an infant and $116 \mathrm{mg} / \mathrm{kg}$ (acute intake) for an adult. A wide range of nitrate intake can produce similar symptoms among individuals because of net differences in gut $\mathrm{pH}$, bacterial activity, and methemoglobin reductase activity. These health effects in infants are summarized in Figure 5.4 as a function of dose.

Data on nitrate toxicity are primarily based on epidemiologic studies of human adults and infants who report to hospitals with symptoms of methemoglobinemia. Exposure doses have been back-calculated from sampling their drinking water in most cases. Therefore, these data do not represent well-controlled studies with readily defined dosage ranges. Many of the water sources in these clinical studies showed contamination with bacteria, leading to the possibility that this bacterial exposure is a necessary cofactor in the development of methemoglobinemia. One laboratory study indicated that healthy infants could drink nitrate at $24 \mathrm{mg} / \mathrm{kg}$-day in solutions free of bacteria and show no symptoms of methemoglobinemia (EPA, 1994a).

Gastrointestinal distress has also been suggested as a cofactor in the development of methemoglobinemia. Infants with colic are more susceptible to nitrate-induced methemoglobinemia than healthy infants (EPA, 1994a).

\subsubsection{Selenium}

\section{Absorption}

Although water-soluble forms of selenium such as selenite are approximately 90 percent absorbed in the gastrointestinal tract in rats, humans show lower percentages of absorption (40 to 80 percent) (Bopp et al., 1982). Absorption by ruminants is only 30 to 35 percent, probably due to bacterial reduction in the rumen. Absorption of the less soluble elemental selenium or selenium sulfide is poor in rats (Medinsky et al., 1981; Cummins and Kimura, 1971).

\section{Tissue accumulation and clearance}

Human studies suggest similar distributions of selenium between humans and laboratory animals (Bopp et al., 1982). At low intake levels, selenium is retained and accumulates in the reproductive organs, brain, and thymus, with only transient accumulation in other organs. Selenite-derived selenium accumulates in the liver and kidneys more rapidly than selenium derived from selenate (Millar et al., 1973). There is some indication that organically bound forms of selenium exist in a separate, more bioavailable pool than either selenite and selenate.

Although urinary excretion is the primary route of elimination under normal dietary conditions ( 67 percent), in deficiency states fecal excretion is the major 

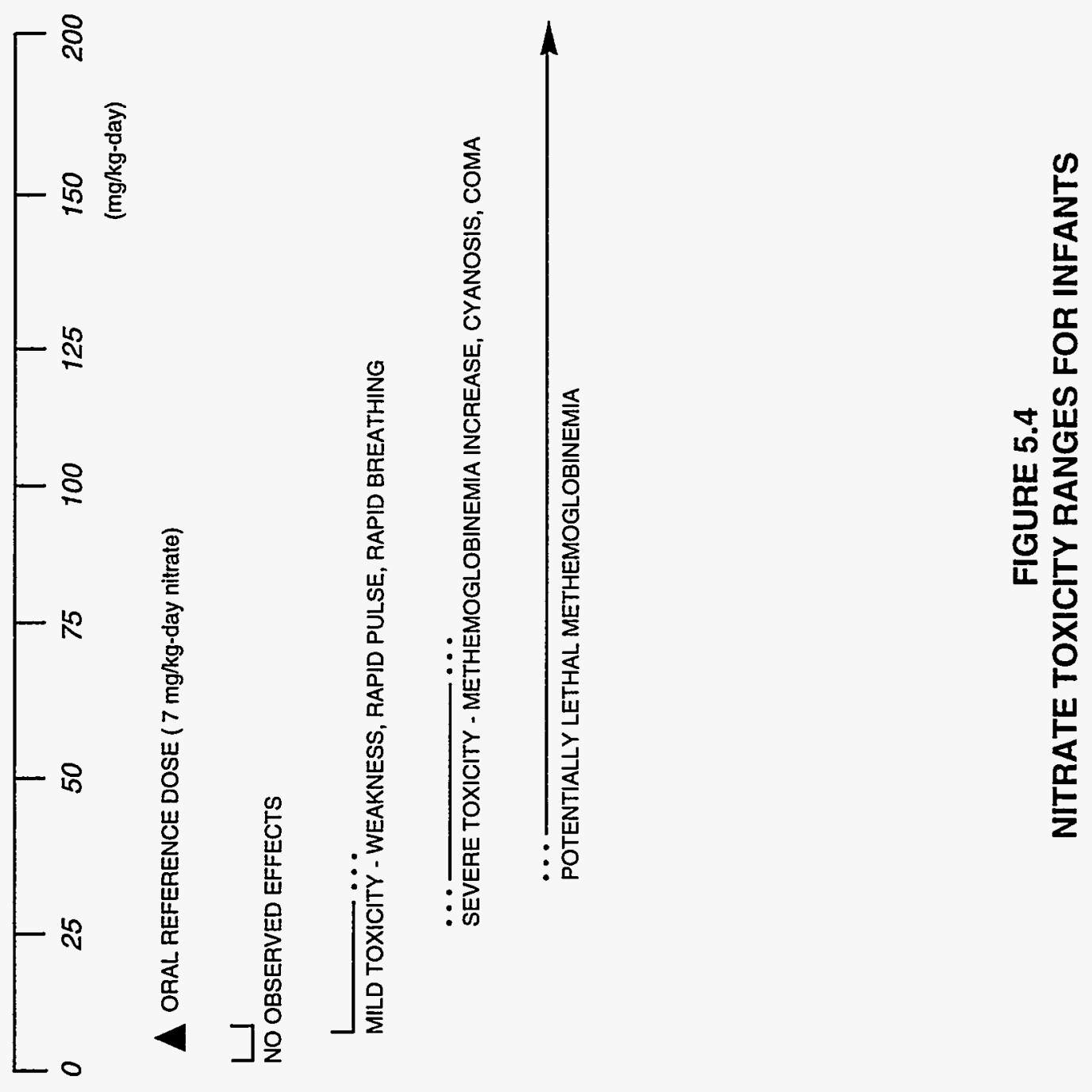
pathway. At toxic doses, the major route of excretion is through expired air as dimethylselenide (50 to 60 percent) (Friberg et al., 1986). Although these data were obtained in rats, available data suggest that human excretion is similar (Bopp et al., 1982). The elimination of selenium in humans follows three phases with the following half-times: $1 ; 8$ to 20; and 65 to 116 days.

\section{Environmental sources of selenium}

The main source of selenium for the general population is foods such as seafood, meat, and grains. Dietary intake of selenium in the United States ranges from 0.0007 to $0.0029 \mathrm{mg} / \mathrm{kg}$-day. Selenium concentrations in ground water and surface water range from 0.00006 to $0.400 \mathrm{mg} / \mathrm{L}$, with highs of $6 \mathrm{mg} / \mathrm{L}$ being reported (Friberg et al., 1986). Concentrations in U.S. public water supplies rarely exceed $0.010 \mathrm{mg} / \mathrm{L}$ (EPA, 1980). High selenium concentrations occur in volcanic rock $(0.120 \mathrm{mg}$ per gram) and in sandstone uranium deposits (1.0 mg per gram). The soil content of selenium varies widely, as does the rate of accumulation by plants. Although grasses and grains do not accumulate selenium in concentrations greater than $50 \mathrm{mg} / \mathrm{kg}$, some plants can accumulate as much as $10,000 \mathrm{mg} / \mathrm{kg}$ if grown in high-selenium regions. These high-accumulating plants are generally not used as food sources but can produce toxic effects if consumed by livestock.

\section{Toxicity of selenium}

Selenium is an essential nutrient. The recommended daily allowance for adults is 0.0006 to $0.0011 \mathrm{mg} / \mathrm{kg}$-day. Although some biochemical alterations, including prolonged prothrombin time and reduced blood glutathione concentrations, can be observed with intakes of selenium from 0.0107 to $0.0121 \mathrm{mg} / \mathrm{kg}$-day, no clinical signs of selenosis are observed with these intakes. Mild toxicity, including hair loss or breakage, thickening and brittleness of nails, and a garlic odor in dermal excretions and breath, were reported in human populations with dietary intakes of selenium from $0.015 \mathrm{mg} / \mathrm{kg}$-day. However, selenium intake as low as $0.013 \mathrm{mg} / \mathrm{kg}$-day can produce symptoms of selenosis such as hair and nail loss in susceptible populations.

Persistent clinical symptoms of selenosis are seen due to the chronic dietary intake of selenium by human populations living in areas of China with high selenium concentrations in soil (from $7 \mathrm{mg} / \mathrm{kg}$ to $12 \mathrm{mg} / \mathrm{kg}$ ). Estimated selenium dietary intake was reported to be $0.018 \mathrm{mg} / \mathrm{kg}$-day for adult women and $0.021 \mathrm{mg} / \mathrm{kg}$-day for adult men (Yang et al., 1989a, 1989b). The average blood selenium concentration associated with this intake of selenium was $1.3 \mathrm{mg} / \mathrm{L}$ (ranging from $1.05 \mathrm{mg} / \mathrm{L}$ to $1.85 \mathrm{mg} / \mathrm{L}$ ). Symptoms of chronic selenosis with hair and nail loss and below normal hemoglobin level were reported in the same study with selenium intake of $0.071 \mathrm{mg} / \mathrm{kg}$-day. The serious outbreak of selenium poisoning, including the possible occurrence of neurotoxic effects such as peripheral anesthesia, acroparesthesia, and pain in extremities, was observed with selenium intake of $0.54 \mathrm{mg} / \mathrm{kg}$-day in both women and men. It is important to note that protein intake by members of this 
population is unknown. These health effects are summarized in Figure 5.5 as a function of dose.

Ingestion of 350 to $4300 \mathrm{mg}$ ( 5 to $61 \mathrm{mg} / \mathrm{kg}$ ) of selenium by adults has produced vomiting, diarrhea, abdominal cramps, numbness in arms, and marked hair loss and irregular menstrual bleeding in women. Higher intakes can result in unsteady gait, cyanosis of mucous membranes, labored breathing, and sometimes death.

Symptoms of "alkali disease and blind staggers" have been seen in grazing livestock feeding over a long period of time upon selenium-accumulating plants in areas with high soil selenium content (Rosenfeld and Beath, 1964). These symptoms include neurological dysfunction such as impaired vision, ataxia, disorientation, and respiratory distress.

\subsubsection{Sodium}

\section{Absorption}

Sodium is rapidly and fully absorbed from the intestinal tract. The skin and lungs also absorb sodium rapidly, by simple diffusion and ion exchange. It travels in the blood, where it ultimately passes through the kidneys. The kidneys filter all the sodium out; then, with great precision, the adrenal hormone aldosterone maintains sodium concentration in the bloodstream at the amount needed (National Research Council, 1980).

\section{Tissue accumulation and clearance}

Sodium is the major extracellular ion. The sodium ion is essential to the regulation of the acid-base balance and is an important contributor to extracellular osmolarity. It is an essential constituent in the electrophysiological functioning of cells and is required for the propagation of impulses in excitable tissues. Furthermore, sodium is essential for active nutrient transport, including the active transport of glucose across the intestinal mucosa. About 30 to 40 percent of the body's sodium is thought to be stored on the surfaces of the bone crystals, where it is easy to recover if the blood sodium level drops.

Excretion of sodium is mainly urinary, with appreciable amounts also excreted in feces, sweat, and tears (Venugopal and Luckey, 1978). Mammalian renal excretion of sodium is a two-phase process involving glomerular filtration and reabsorption in proximal tubules; of about 600 grams of sodium involved in 24-hour glomerular filtration, approximately 99.5 percent is reabsorbed in human adults. As previously described, a homeostatic mechanism for sodium functions at the renal excretory level. 


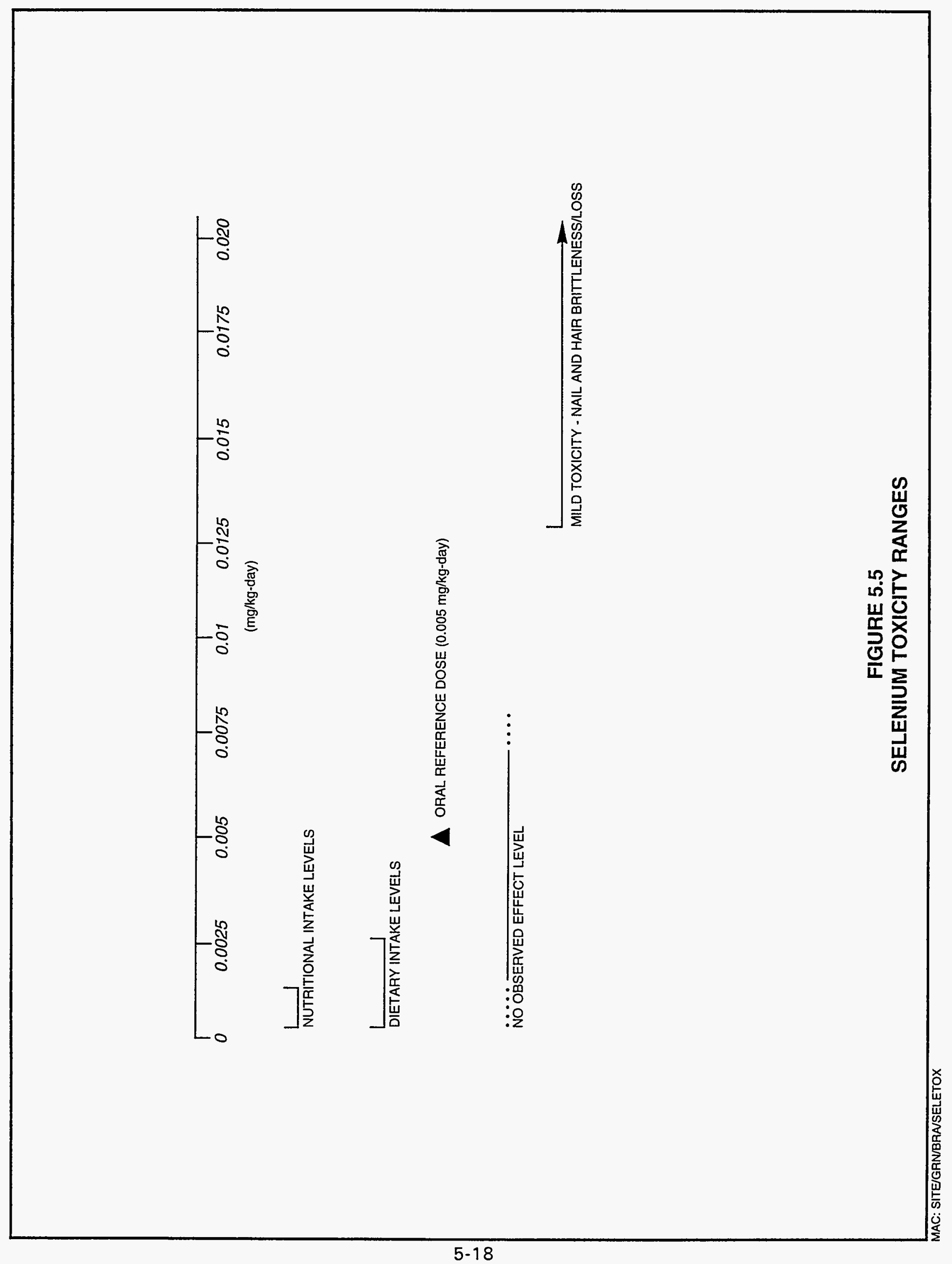




\section{Environmental sources of sodium}

The total intake of sodium is influenced mainly by the extent that salt (sodium chloride) is used as an additive to food, the inherent salt content of the foods consumed, and the intake of other sodium salts in the diet and in medications. Sodium is a natural constituent of both vegetable and animal products in varying concentrations. Other sources of sodium are medications, drinking water, cooking water, soft drinks, and alcoholic beverages.

At 2 months, infants consume approximately $300 \mathrm{mg}$ of sodium a day; at 12 months, approximately $1400 \mathrm{mg}$ a day. Human milk contains $161 \mathrm{mg} / \mathrm{L}$ and cow's milk contains approximately $483 \mathrm{mg} / \mathrm{L}$ (Carson et al., 1986).

The National Research Council recommendations advise limiting daily sodium intake to less than $2400 \mathrm{mg}$ ( $34 \mathrm{mg} / \mathrm{kg}$-day). A healthy person requires about $115 \mathrm{mg}$ sodium daily $(1.6 \mathrm{mg} / \mathrm{kg}$-day), yet sodium dietary intake is estimated at 57 to $85 \mathrm{mg} / \mathrm{kg}$-day. However, dietary sodium intake levels as high as $134 \mathrm{mg} / \mathrm{kg}$-day have been reported (National Research Council, 1980). The American Heart Association recommends limiting sodium intake to $3000 \mathrm{mg}$ daily (about $43 \mathrm{mg} / \mathrm{kg}$ for a $70-\mathrm{kg}$ individual).

The sodium content of drinking water is extremely variable. Sodium concentrations in 630 water supply systems nationwide ranged from less than 1 to $402 \mathrm{mg} / \mathrm{L}$ (resulting in drinking water ingestion rates from less than 0.03 to $11 \mathrm{mg} / \mathrm{kg}$-day), with 42 percent greater than $20 \mathrm{mg} / \mathrm{L}$ and 3 percent over $200 \mathrm{mg} / \mathrm{L}$ (Carson et al., 1986).

\section{Toxicity of sodium}

Acute toxicity symptoms from sodium chloride in healthy adult males accompanied by visible edema may occur with an intake of 35 to 40 grams of salt per day $(200$ to $220 \mathrm{mg}$ sodium $/ \mathrm{kg}$-day, since sodium is 39 percent of the weight of sodium chloride) (Meneely and Battarbee, 1976). The mean lethal dose of sodium for humans was reported to be $3230 \mathrm{mg} / \mathrm{kg}$ (Venugopal and Luckey, 1978).

Epidemiological studies have indicated that long-term excessive sodium intake is one of many factors associated with hypertension in humans. A high sodium/. potassium ratio in the diet may be detrimental to persons susceptible to high blood pressure. Some adults, however, tolerate chronic intake above 40 grams of sodium chloride per day (equivalent to $220 \mathrm{mg} / \mathrm{kg}$-day) (Carson et al., 1986).

Research shows that there appear to be critical levels of sodium ingestion that cause blood pressure to rise with age and hypertension to develop in some people. It has been reported that with sodium intake below $227 \mathrm{mg} / \mathrm{day}$ ( $3 \mathrm{mg} / \mathrm{kg}$-day for a 70-kg adult), hypertension was absent (Freis, 1976). In the range of 227 to $1591 \mathrm{mg} /$ day ( 3 to $23 \mathrm{mg} / \mathrm{kg}$-day for a $70-\mathrm{kg}$ adult), a few cases of hypertension may appear, while in the range of 1590 to $8000 \mathrm{mg} / \mathrm{day}$ 
(23 to $114 \mathrm{mg} / \mathrm{kg}$-day for a 70-kg adult), approximately 15 percent of adults would exhibit hypertension. When sodium intake rises above $8000 \mathrm{mg} / \mathrm{day}$, hypertension may be found in about 30 percent of the population.

Because sodium chloride is present in nearly all processed and packaged foods, it is difficult to limit dietary sodium intake. Average daily intakes in the United States from dietary sources are often within a range where hypertensive effects occur. Drinking water generally contains relatively low levels of sodium and therefore does not significantly contribute to the total intake, unless sodium is at higher than average levels in the water supply. However, people on sodiumrestricted diets can obtain a significant portion of daily sodium from drinking water. Because the kidney is the major organ involved in regulating sodium balance, individuals with compromised kidney function may be placed on a lowsodium diet. In addition, other individuals may be on low-sodium diets to control hypertension. Because of the high prevalence of such individuals in our society, the American Heart Association has proposed that public drinking water supplies in the United States adopt a standard of $20 \mathrm{mg} / \mathrm{L}$ sodium to protect individuals on low sodium diets (Calabrese and Tuthill, 1977). This would limit the additional intake of sodium from drinking water to approximately $0.6 \mathrm{mg} / \mathrm{kg}$-day for a $70-\mathrm{kg}$ adult.

The potential health effects of sodium as a function of dose are summarized in Figure 5.6.

\subsubsection{Sulfate}

\section{Absorption}

Sulfate absorption from the gastrointestinal tract is similar between humans and other animals. Generally, greater than 90 percent absorption has been reported for doses of sulfate below $150 \mathrm{mg} / \mathrm{kg}$, decreasing to 50 to 75 percent as the dose increases into the grams per kilogram range.

\section{Tissue accumulation and retention}

Ingestion of high levels of sulfate results in transient increases in both blood and urine concentrations. For sulfate doses of approximately $75 \mathrm{mg} / \mathrm{kg}$, approximately 50 percent of the dose is excreted over 72 hours. The urinary excretion mechanism is transport-limited and can therefore become saturated at high doses of sulfate. Excess sulfate is also excreted in feces in its inorganic form. To date, no data are available that indicate sulfate is accumulated, even with chronic ingestion of above-normal levels. However, extremely high chronic doses do not appear to have been examined in humans.

Sulfate is used in the biosynthesis of collagen, cartilage, and dentin and in the formation of sulfate esters of both endogenous compounds (such as lipids and steroids) and exogenous compounds (such as phenols). Sulfation is important in detoxication pathways because it increases the solubility of these compounds, 

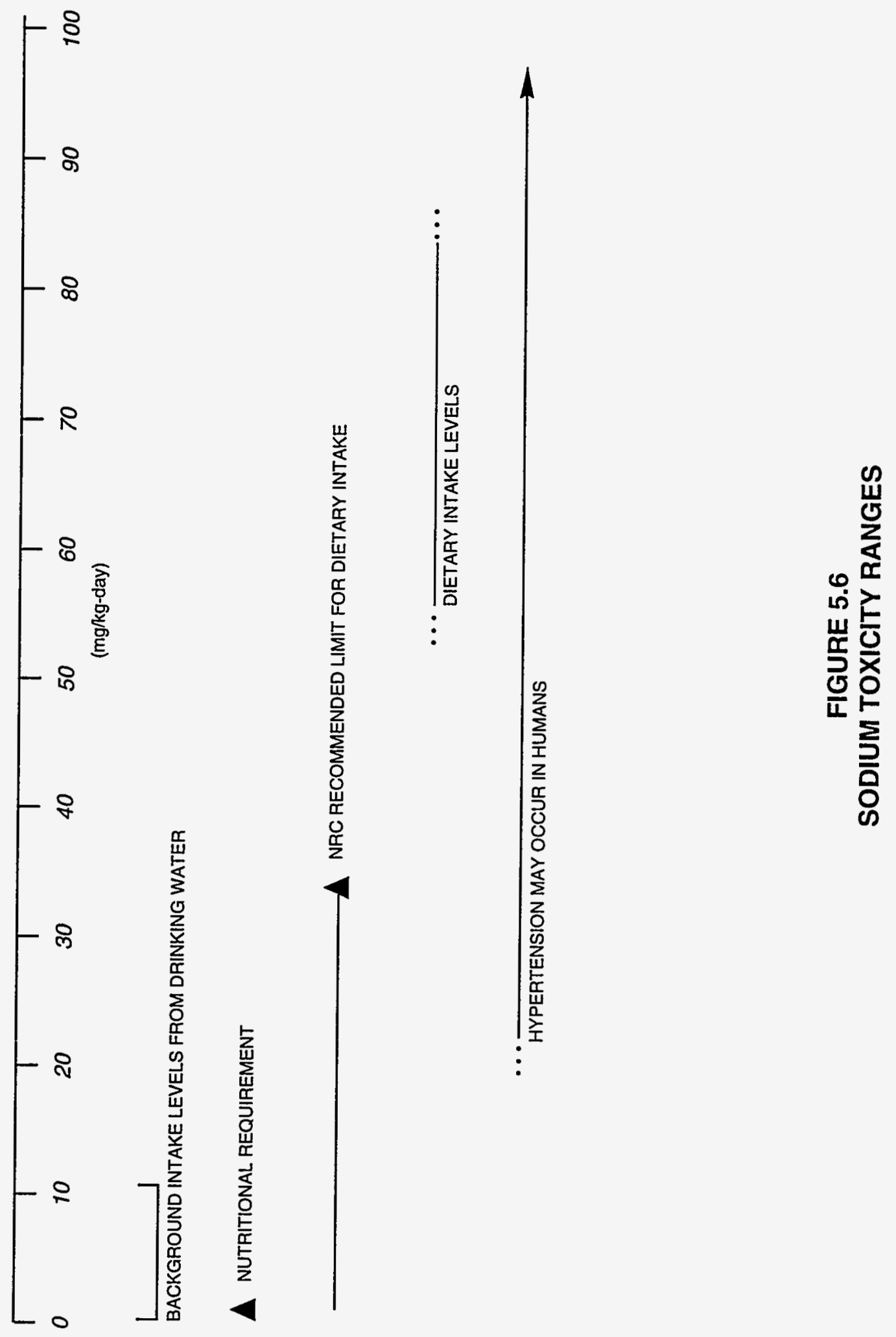
which enhances their excretion in the urine. Exposure to high concentrations of compounds that are conjugated with sulfate and excreted can produce a transient decrease in sulfate concentrations in plasma.

\section{Environmental sources of sulfate}

Drinking water in the western United States in 1978 showed a range of sulfate concentrations from 0 to $820 \mathrm{mg} / \mathrm{L}$, with a mean concentration of $99 \mathrm{mg} / \mathrm{L}$ of sulfates. The EPA estimates a normal sulfate intake range of 0.00023 to $0.0064 \mathrm{mg} / \mathrm{kg}$-day from air and 0.000 to $2.9 \mathrm{mg} / \mathrm{kg}$-day from drinking water in the concentration range found in supplies in the western United States. No estimates are available on intake of sulfates from food sources.

\section{Toxicity of sulfate}

As with nitrate toxicity, the acute and chronic effects of sulfate toxicity differ more in severity than in symptoms or mechanisms. Therefore, this discussion will combine acute and chronic toxicity. As mentioned above, there are no data to indicate a bioaccumulation of sulfate with chronic exposure. Sulfate salts of magnesium and sodium are used medicinally as cathartics. The presence of high concentrations of unabsorbed sulfate salts in the gut can pull large amounts of water into the gut, greatly increasing the normal volume of feces. This is the basis of the toxic effects as well.

Toxicity in humans is primarily manifested in diarrhea; the severity of the diarrhea is dose-dependent. Chronic ingestion of sulfate can result in persistent diarrhea, leading to ionic imbalances and dehydration similar to that seen with extremely high acute doses. In the case of drinking water contaminated with sulfate, the taste of the water may make it unpalatable and reduce consumption. However, this is not necessarily the case. In regions such as Saskatchewan with high sulfate concentrations in the drinking water, residents adapt to the taste and find the water palatable (EPA, 1992a). In cases where consumption is reduced, a lower water intake could compound the dehydration effects of the diarrhea. Extreme dehydration can lead to death. As with nitrate toxicity, infants seem to be the most susceptible population for sulfate-induced diarrhea. Also, some data indicate that diabetic and elderly populations with compromised kidney function may be more sensitive than healthy adults to the effects of sulfates (EPA, 1992a).

In cattle, high sulfate intake has resulted in sulfhemoglobinemia, a condition similar to the methemoglobinemia induced by nitrate ingestion (EPA, 1992a). No reports of sulfhemoglobinemia have been reported following ingestion of sulfate by humans, although the condition has been reported in humans following inhalation of hydrogen sulfide.

As with nitrate, data on sulfate toxicity are based primarily on epidemiologic studies of human adults and infants who report to hospitals with symptoms of sulfate exposure. In most cases, exposure doses have been back-calculated 
from sampling their drinking water. Therefore, these data do not represent well-controlled studies where dosage ranges can be readily defined.

Potential toxic effects from sulfate ingestion are summarized as a function of dose in Figure 5.7.

\subsubsection{Uranium}

Naturally occurring uranium, present at UMTRA Project sites, consists of three radioactive isotopes: uranium-234, uranium-235, and uranium-238. More than 99 percent of natural uranium occurs in the form of uranium-238 (Cothern and Lappenbusch, 1983). Uranium-238 undergoes radioactive decay by emitting alpha particles to form uranium-234, thorium-230, radium-226, radon 222 , polonium-210, and other radioisotopes. The radioactive decay chain of uranium238 and uranium-234 is summarized in Figure 5.8. As all uranium isotopes in nature are radioactive, the hazards of a high uranium intake are from both its chemical toxicity and potential radiological damage. This section focuses on the chemical toxicity of natural uranium. Carcinogenic potential associated with exposure to radioactive isotopes of natural uranium is discussed in Section 5.3.

\section{Absorption}

Absorption of uranium in the gastrointestinal tract depends on the solubility of the uranium compounds. The hexavalent uranium compounds, especially the uranyl salts, are water-soluble, while tetravalent compounds generally are not (Weigel, 1983). Even with soluble compounds, only a small fraction is absorbed. Human gastrointestinal absorption rates of 0.76 to 7.8 percent have been determined (Wrenn et al., 1985).

\section{Tissue accumulation and clearance}

In humans exposed to background levels of uranium, the highest concentrations of uranium were found in the bones, muscles, lungs, liver, and kidneys (Fisenne et al., 1988). Uranium retention in bone consists of a short retention half-time of 20 days, followed by a long retention half-time of 5000 days for the remainder (Tracy et al., 1992).

In body fluids, uranium tends to be converted into water-soluble hexavalent uranium (Berlin and Rudell, 1986). Approximately 60 percent of the uranium in plasma complexes with low-molecular-weight anions (e.g., bicarbonates, citrates), while the remaining 40 percent binds to the plasma protein transferrin (Stevens et al., 1980). Following oral exposure in humans, more than 90 percent of uranium is excreted in the feces and not absorbed in the gastrointestinal tract. Of the small percent that is absorbed (typically less than 5 percent), approximately 60 percent is excreted in the urine within 24 hours and 98 percent is excreted within 7 days, based on animal studies (Ballou et al., 1986; Leach et al., 1984; Sullivan et al., 1986). A small portion of the absorbed uranium is retained for a longer period. 


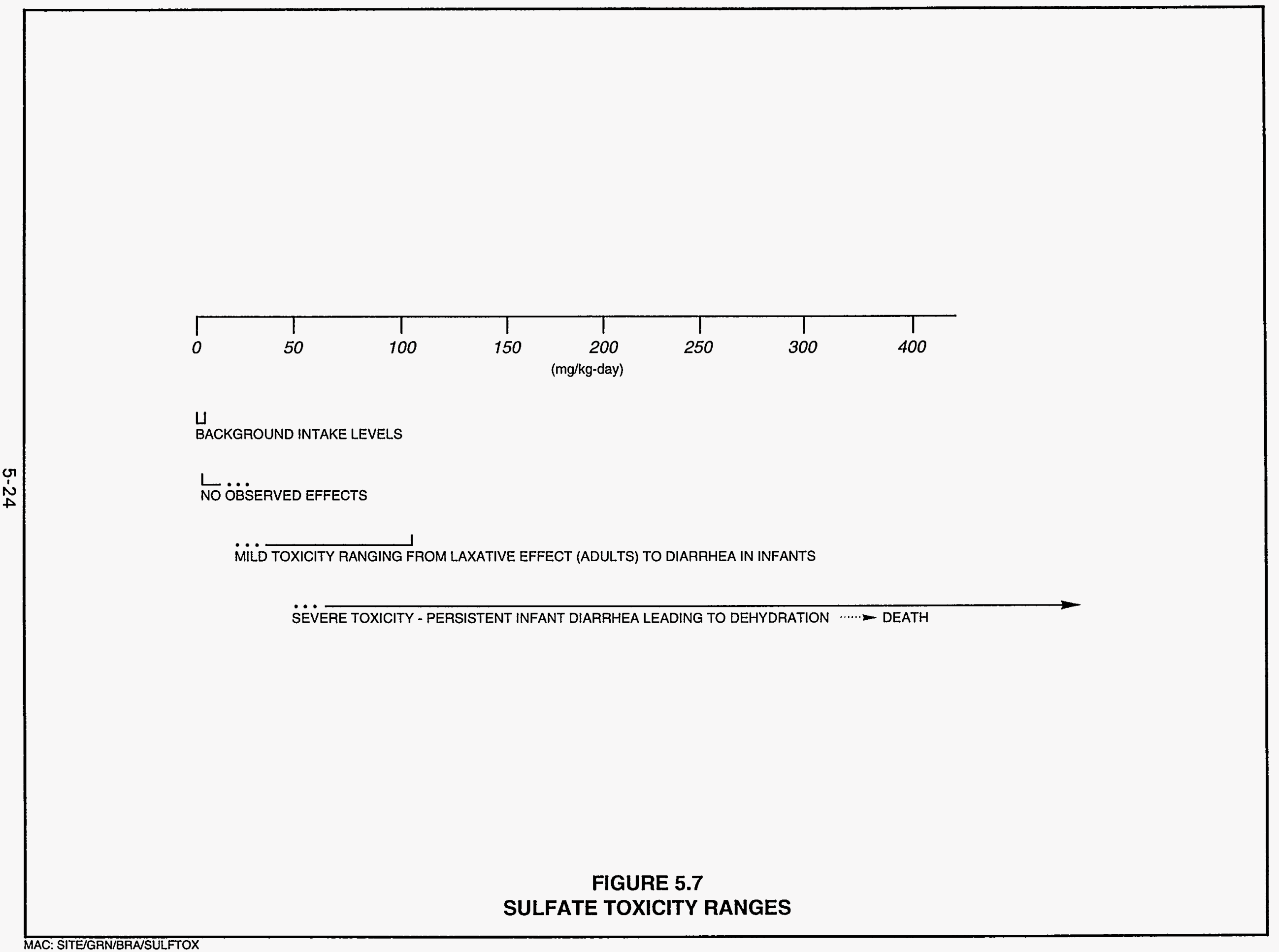




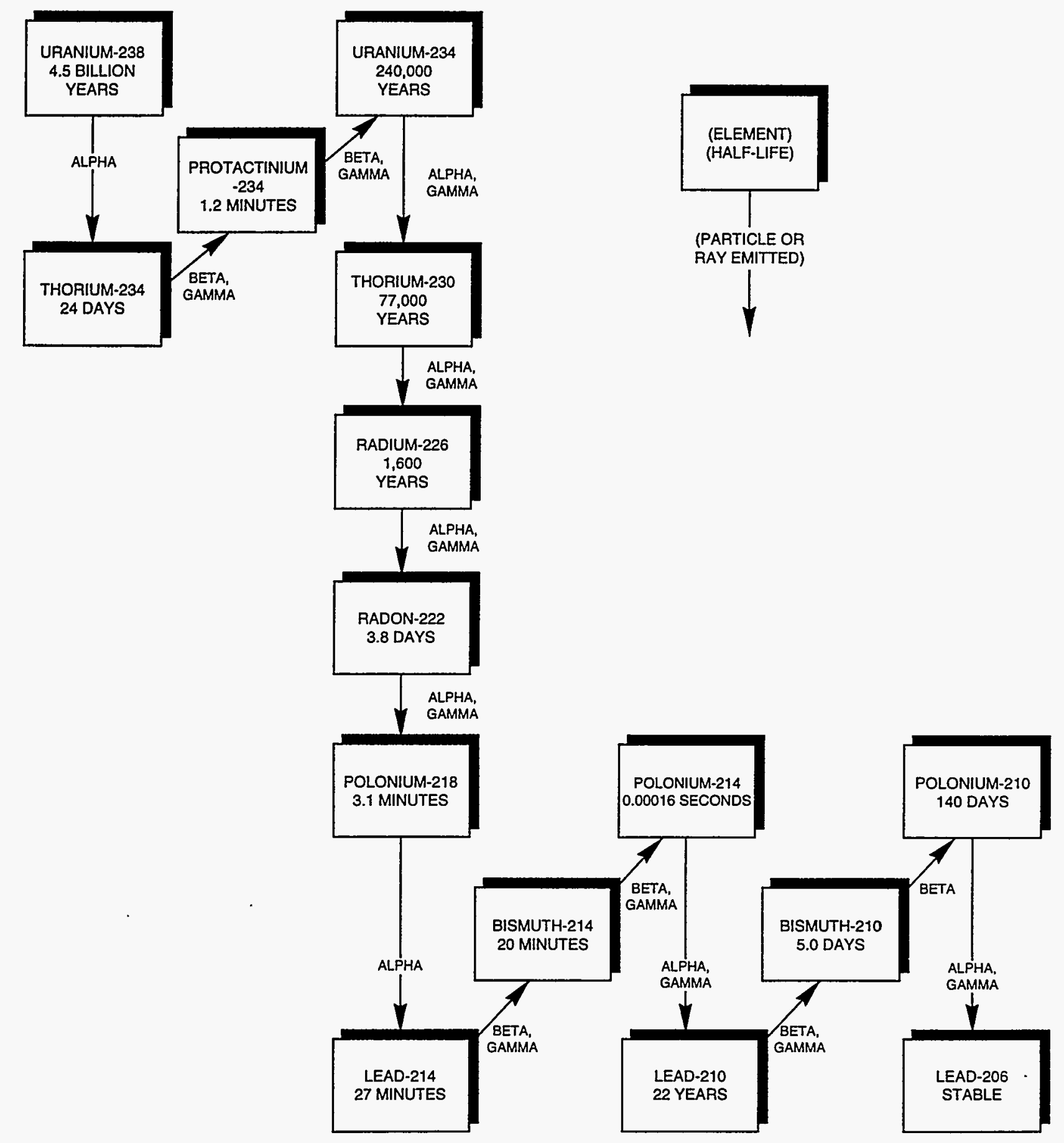

FIGURE 5.8

HALF-LIVES AND EMISSIONS FROM DECAY CHAIN OF URANIUM-238 


\section{Environmental sources of uranium}

Uranium is a ubiquitous element, present in the earth's crust at approximately 4 parts per million. Uranium concentrations in ground water and surface water averaged $1 \mathrm{pCi} / \mathrm{L}$ and $3 \mathrm{pCi} / \mathrm{L}$, respectively (NCRP, 1984). Absorption from soil into plant tissues depends on the plant species and the depth of its root system (Berlin and Rudell, 1986). Plant concentrations of uranium averaged 0.075 micrograms per kilogram $(\mu \mathrm{g} / \mathrm{kg}$ ) of fresh plant material (Tracy et al., 1983).

The main dietary source of natural uranium for the general population is food products such as potatoes, bakery products, meat, and fresh fish, which may contain uranium concentrations between 10 and $100 \mu \mathrm{g} / \mathrm{kg}$ (Prister, 1969). The total dietary intake of uranium from the consumption of average foods is approximately $1 \mu \mathrm{g}$ per day; approximately 20 to 50 percent of that total can come from drinking water. Cereals and vegetables, particularly root crops, are likely to contribute most to the daily intake of uranium (Berlin and Rudell, 1986).

\section{Toxicity of uranium}

Exposure of the general public to natural uranium is unlikely to pose an immediate lethal threat to humans. No human deaths have been reported that are definitely attributable to uranium ingestion; therefore, no lethal dose has been determined for humans. In laboratory animals, lethal doses of uranium $\left(L D_{50,23}\right)$ have been reported to be as low as $14 \mathrm{mg} / \mathrm{kg}$-day following 23-day oral exposures, depending on the solubility of the uranium compound tested (higher solubility compounds have greater toxicity), route of exposure, and animal species. High doses of uranium cause complete kidney and respiratory failure.

No chronic toxic effects have been reported in humans following oral exposure to uranium. Data available from populations occupationally exposed to high concentrations of uranium compounds through inhalation and information from studies in experimental animals indicate that the critical organ for chronic uranium toxicity is the proximal tubule of the kidney (Friberg et al., 1986). In humans, chemical injury reveals itself by increased catalase excretion in urine and proteinuria. Dose-response data for the toxic effect of uranium on the human kidney are limited. The lowest dose of uranyl nitrate that caused moderate renal damage was given to rabbits in diet at $2.8 \mathrm{mg} / \mathrm{kg}$-day (Maynard and Hodge, 1949).

The health effects of uranium are summarized in Figure 5.9 as a function of dose. 


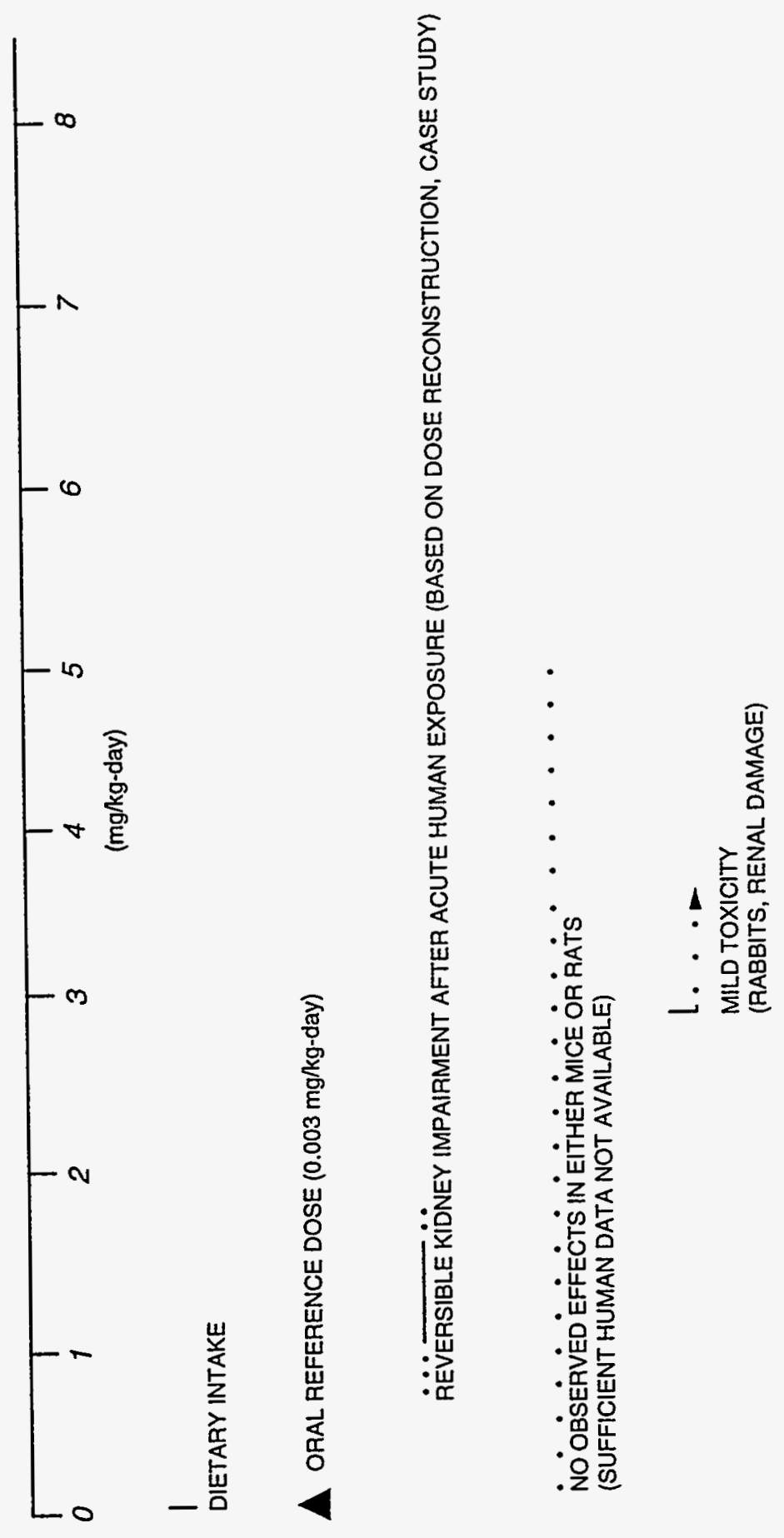

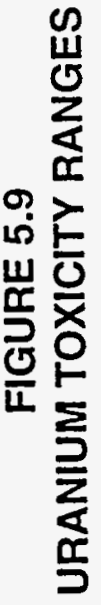




\subsubsection{Vanadium}

\section{Absorption}

Absorption of vanadium from the gastrointestinal tract is low. The International Commission on Radiological Protection (ICRP) (1960) estimate for the absorption of soluble vanadium compounds is 2 percent, but the World Health Organization (WHO) states that absorption of even very soluble forms of vanadium is less than 1 percent from the gastrointestinal tract (WHO, 1988). Limited human data (from three individuals) have suggested as much as 10 percent of a repeated oral dose may be absorbed (Proescher et al., 1917; Tipton et al., 1969). Soluble vanadium compounds that are inhaled and deposited are more readily absorbed (about 25 percent) (WHO, 1988). Although soluble forms of vanadium may be absorbed through the skin, absorption via this route is probably minimal (EPA, 1977; WHO, 1988).

\section{Tissue accumulation and clearance}

Vanadium is found in all body tissues in concentrations ranging from $0.08 \mu \mathrm{g}$ per gram wet weight in spleen tissue to $0.14 \mu \mathrm{g}$ per gram in brain and heart tissue and $0.33 \mu \mathrm{g}$ per gram in aorta tissue (Yakawa and Suzuki-Yasumoto, 1980). Concentrations of vanadium in human blood serum are reported to be 0.016 to 0.939 nanograms per milliliter $(\mathrm{ng} / \mathrm{mL})$. In hair, concentrations of vanadium ranging from 20 to $60 \mathrm{ng}$ per gram have been reported by different authors, with higher values found in manic-depressive patients (57 ng per gram) than in normal control groups (29 ng per gram).

The distribution of vanadium in humans following oral exposure may be extrapolated from animal studies. In acute-duration exposures, vanadium is rapidly distributed, primarily in the bones. After intermediate-duration exposure, vanadium concentrations reaching the tissues are low, with the kidneys, bones, liver, and lungs initially showing the highest levels.

Vanadium is an element and is not metabolized. However, in the body, there is an interconversion of two oxidation states of vanadium: vanadyl and vanadate. Vanadium can reversibly bind to the protein transferrin in the blood and then be taken up into erythrocytes. There is a slower uptake of vanadyl into erythrocytes compared to the vanadate form, possibly due to the time required for the vanadyl form to be oxidized to vanadate. Initially, vanadyl leaves the blood more rapidly than vanadate, possibly because of the slower vanadyl uptake into cells (Harris et al., 1984). Five hours after administration, blood clearance is essentially identical for the two forms. Vanadate is the dominant species of vanadium present in ground water at the Green River site.

Because vanadium is poorly absorbed in the gastrointestinal tract, a large percentage of vanadium in rats is excreted unabsorbed in the feces following oral exposure. In rats, the principal route of excretion of the small absorbed 
portion of vanadium is through the kidneys. The mean urinary output per 24 hours is reported to be $10 \mu \mathrm{g}$.

\section{Environmental sources of vanadium}

Elemental vanadium does not occur in nature, but its compounds exist in more than $\mathbf{5 0}$ different mineral ores and in association with fossil fuels. The single largest release of vanadium to the atmosphere occurs through the combustion of fossil fuels, particularly residual fuel oils. The largest amount of vanadium released to soil and water occurs through natural weathering of geological formations (Byerrum et al., 1974; Van Zinderen Bakker and Jaworski, 1980).

Food constitutes the major source of exposure to vanadium for the general population (Lagerkvist et al., 1986). As a whole, dietary intake is estimated to be 6 to $18 \mu \mathrm{g} / \mathrm{day}$ (Pennington and Jones, 1987), although other estimates from older studies using different (and possibly less sensitive) analytical methods have been as high as $2 \mathrm{mg} /$ day (Schroeder et al., 1963).

Drinking water is not considered an important source of vanadium exposure for the general population. Water samples taken from across the United States show 92 percent with values below $10 \mu \mathrm{g} / \mathrm{L}$. Typical values appear to be around $1 \mu \mathrm{g} / \mathrm{L}$ (Lagerkvist et al., 1986). The estimated daily intake of vanadium by inhalation is $1 \mu \mathrm{g}$ (Byrne and Kosta, 1978).

Although vanadium is considered an essential element for chickens and rats, there is no certainty about human dietary requirements. For animals, the daily requirement is about 10 to $25 \mu \mathrm{g} /$ day (Pennington and Jones, 1987).

\section{Toxicity of vanadium}

The major adverse health effect to humans from vanadium is seen in workers exposed to large amounts of vanadium pentoxide dusts. The probable oral lethal dose of vanadium pentoxide for humans is between 5 and $50 \mathrm{mg} / \mathrm{kg}$ (Gosselin et al., 1976).

Systemic effects of vanadium exposure have been observed in the liver, kidneys, nervous and cardiovascular systems, and blood-forming organs. Metabolic effects include interference with the biosynthesis of cystine and cholesterol, depression and stimulation of phospholipid synthesis, and, at higher concentrations, inhibition of serotonin oxidation. Other effects of vanadium on mammalian metabolism include depression of phospholipid synthesis (Snyder and Cornatzer, 1958), reduction of coenzyme $Q$ levels in mitochondria (Aiyar and Sreenivasan, 1961), and stimulation of monoamine oxidase, which oxidizes serotonin (Perry et al., 1955).

Vanadium salts were given to patients in several studies to reduce cholesterol levels (Curran et al., 1959; Somerville and Davies, 1962; Dimond et al., 1963; Schroeder et al., 1963). The doses of vanadium in these studies varied from 
7 to $30 \mathrm{mg} /$ day. Transient decreases in serum cholesterol levels were observed in some patients, as were loosened stool and cramps. Green tongue, a hallmark of vanadium exposure, was observed in all patients.

A relationship between the concentration of vanadium in drinking water and the incidence of dental caries in children is reported by Tank and Storvick (1960). Dental caries incidence in children aged 7 to 11 years was reduced three times (compared to controls) by applying ammonium vanadate in glycerol to the teeth (Belehova, 1969). This relationship was not found in other studies (Hadjimarkos, 1966; 1968).

It has been suggested that raised tissue levels of vanadium are important in the etiology of manic-depressive illness. Improvement after treatment with ascorbic acid or reduced vanadium intake was seen both in manic and depressed patients.

Although animal studies have reported impaired conditioned reflexes following doses of vanadium from $0.05 \mathrm{mg} / \mathrm{kg}$-day (after 6 months of exposure) to $0.5 \mathrm{mg} / \mathrm{kg}$-day (after 21 days of exposure), effects on the nervous system have not been observed following repeated oral administration of vanadium in humans. Workers exposed by inhalation to fairly high concentrations of vanadium compounds have reported nonspecific symptoms, including headache, weakness, vomiting, nausea, and ringing of the ears (WHO, 1988).

Available data on vanadium toxicity are insufficient to evaluate its effect on cholesterol levels, iron metabolism, blood-cell production, and mutagenesis. However, due to poor absorption from the gut, the metal is not considered very toxic following oral administration (WHO, 1988). The toxicity of vanadium is summarized in Figure 5.10.

\subsection{CONTAMINANT INTERACTIONS}

Some information is available on potential interactions between contaminants found at UMTRA Project sites. However, discussions of potential interactions must generally be presented qualitatively. In addition to physiological variables among individuals that can affect toxicity, uncertainties in interactions also result from 1) differences in the relative exposure concentrations of the different contaminants compared to the concentrations tested experimentally; and 2) the presence of additional ground water constituents that may occur in sufficient quantities to modify predicted toxicities, even though they themselves are not considered contaminants of concern for human health. Therefore, the interactions described below should be recognized as factors that can influence the predicted toxicity, although the precise nature and magnitude of that influence cannot be determined.

A primary concern at Green River is the potential for nitrate-sulfate interactions. No clear data are available to assess this interaction, but the epidemiological evidence suggests that in infants, gastrointestinal upset, such as that caused by 


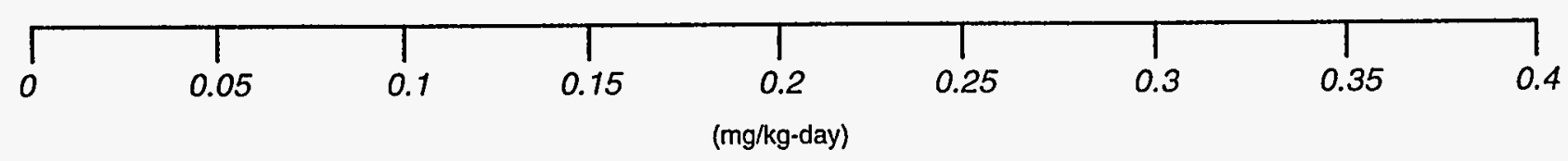

| DIETARY INTAKE

A ORAL REFERENCE DOSE - DRINKING WATER (0.007 mg/kg-day) IMPAIRED CONDITIONED REFLEXES (RATS)

TRANSIENT CHOLESTEROL DROP, CRAMPS, GREEN TONGUE

ESTIMATED ACUTE LETHAL DOSE $(5-50 \mathrm{mg} / \mathrm{kg})$

FIGURE 5.10

VANADIUM TOXICITY RANGES 
sulfate, could increase the sensitivity of infants to methemoglobinemia produced by nitrates. However, it is also possible that sulfate-induced diarrhea could decrease the nitrate-reducing bacteria in the intestine, thereby causing a decreased nitrate toxicity.

Interactions between nitrate, sulfate, and hemoglobin also occur. However, no studies have been found that address the potential interactions in a combined exposure to high concentrations of both nitrate and sulfate. Nitrate has been used to treat hydrogen sulfide poisoning. The hydrosulfide anion binds to methemoglobin to form sulfmethemoglobin, effectively removing circulating hydrosulfide. Additional data are needed to assess the likelihood of hydrosulfide formation with oral sulfate exposure or the subsequent formation or stability of sulfmethemoglobin.

Interactions between several similar metals can alter the predicted absorption, distribution in the body, metabolism, toxicity, or clearance of a specific metal. For example, the absorption of manganese can be considerably altered under conditions of low calcium, iron, or protein. Absorption of manganese from the intestine may significantly increase in the presence of low dietary iron, leading to increased manganese toxicity (DHHS, 1992). High levels of manganese lead to decreased iron absorption.

Selenium interacts with a wide range of metals, including arsenic, bismuth, cadmium, cobalt, copper, lead, mercury, platinum, silver, tellurium, and thallium (Friberg et al., 1986). Selenium forms insoluble complexes with silver, copper, cadmium, and mercury. Selenium deficiency may develop in the presence of these other metals, as is seen with cobalt and copper. The formation of these complexes can reduce the toxicity of both selenium and the other metal (Casarett and Doull, 1991). Most of these interactions have been observed in laboratory animals or in livestock. The mechanisms are not completely understood in many cases. Often the selenium-metal complex binds in a stable complex to a larger protein than the metal alone, and a redistribution of this complex occurs away from target tissues. Selenium and arsenic together can reduce their respective toxicities. However, some methylated metabolites of selenium can increase the toxicity of arsenic (DHHS, 1989). Sulfate can also interact with selenium, but the interaction is inconsistent. Sulfate can reduce some toxic effects of selenium, but not others such as liver damage at high doses (DHHS, 1989).

A single study in mice suggests that vanadium and manganese interact and alter the behavioral development of the pups as compared to either element administered alone (DHHS, 1992). Oral administration of vanadium alone may interfere with copper metabolism by inhibiting the intestinal absorption of copper.

Because ingesting high levels of sulfate produces diarrhea that will lead to dehydration, and ingesting high levels of sodium leads to sodium retention, a physiological interaction might be expected to occur with simultaneous ingestion 
of both. However, no available data predict the net effects of chronic ingestion of sulfate and sodium at high concentrations. Although high concentration sodium solutions are used to treat diarrhea-induced hyponatremia, this treatment uses solutions with physiologically balanced electrolyte concentrations. Disproportionately high sodium levels could intensify the electrolyte loss produced by severe diarrhea.

No information on uranium interactions with other metals has been found. However, the common target organ suggests interaction of uranium, vanadium, and arsenic, resulting in increased kidney toxicity.

Finally, diarrhea-caused dehydration may lead to excessive concentration of contaminants (those excreted in urine) in the kidney; thus, it may enhance predicted toxicity resulting from exposure to these contaminants.

\subsection{CONTAMINANT RISK FACTORS}

The EPA Office of Research and Development has calculated acceptable intake values, or reference doses (RfD), for long-term (chronic) exposure to noncarcinogens. These values are estimates of route-specific exposure levels that would not be expected to cause adverse effects when exposure occurs for a significant portion of a lifetime. The RfDs include safety factors to account for uncertainties associated with limitations of the toxicological data base, including extrapolating results from animal studies to humans and accounting for variability in response from sensitive individuals. These values are updated quarterly and are published in the Health Effects Assessment Summary Tables (HEAST). Following more stringent review, they are published through the EPA'S IRIS data base. The most recent oral RfDs for the noncarcinogenic contaminants of potential concern are summarized in Table 5.2.

The EPA currently classifies all radionuclides as Group A, or known human carcinogens, based on their property of emitting ionizing radiation and on evidence provided by epidemiological studies of radiation-induced cancer in humans. At sufficiently high doses, ionizing radiation acts as a complete carcinogen (both initiator and promoter), capable of increasing the probability of cancer development. However, the actual risk is difficult to estimate, particularly for the low doses and dose rates encountered in the environment. Most of the reliable data were obtained under conditions of high doses delivered acutely. It is not clear whether cancer risks at lower doses are doseproportional (i.e., the linear dose-response hypothesis) or whether the risk is greatly reduced at low doses and rates (the threshold hypothesis). A conservative assumption rejects the threshold hypothesis and assumes that any dose and dose rate add to the risk of cancer.

Risk factors are published in HEAST and IRIS for correlating the intake of carcinogens over a lifetime with the increased excess cancer risk from that exposure. The most recent cancer SFs for the uranium-234/-238 radioactive decay series and the chemical carcinogen arsenic are given in Table 5.1. 


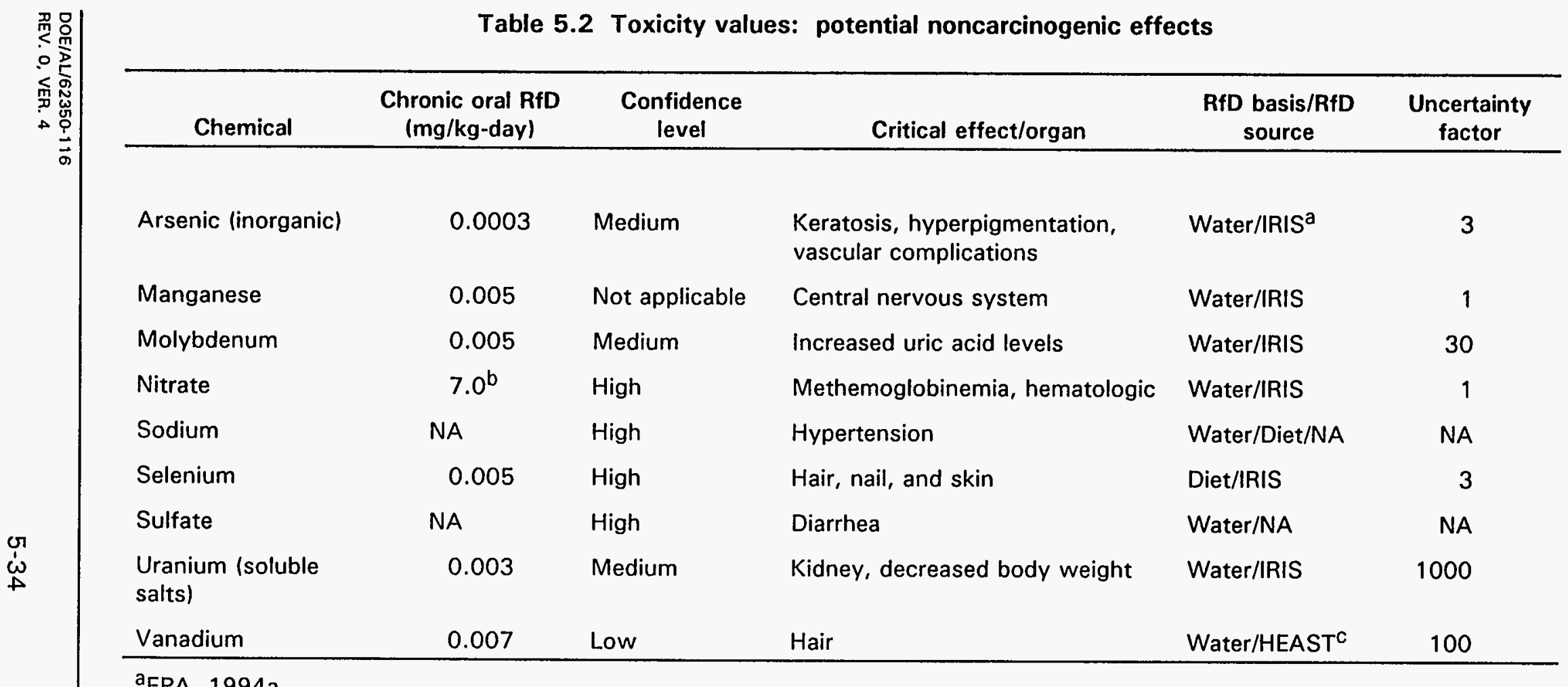

PA, 1994a.

${ }^{b} V a l u e$ represented as nitrate; nitrate-nitrogen $R f D$ is $1.6 \mathrm{mg} / \mathrm{kg}$-day.

CEPA, 1994b.

NA - not available. 
exposure. The most recent cancer SFs for the uranium-234/-238 radioactive decay series and the chemical carcinogen arsenic are given in Table 5.1. 


\subsection{HUMAN HEALTH RISK EVALUATION}

To evaluate human health risks to an individual or population, the results of the exposure assessment are combined with the results of the toxicity assessment. As discussed in Section 5.0, potential adverse health effects are a function of how much of the contaminant an individual takes into his or her body. At lower levels, many of the contaminants associated with the mill tailings are beneficial to health, since they are essential nutrients. At higher levels, these same elements can cause adverse health effects or, at very high levels, death.

\subsection{POTENTIAL NONCARCINOGENIC HEALTH EFFECTS}

\subsubsection{Brown's Wash alluvium ground water potential use}

As discussed in Section 4.0, human health risks associated with potential future uses of the Brown's Wash alluvium ground water could not be fully evaluated. In this section, to estimate potential toxicity of the contaminated ground water the Brown's Wash alluvium if humans drank this water, maximum observed concentrations of nitrate, sulfate, and uranium (from Table 3.2) are compared to the concentrations that could produce adverse health effects. For nitrate and sulfate, infant exposures are used to estimate potential toxicity from drinking contaminated ground water, because infants represent the most toxicologically sensitive population. For uranium, exposures of children and adults are evaluated. These ground water contaminants are selected because they are most likely to be associated with the former uranium processing site. In addition, these three contaminants at the observed concentrations (Table 3.2) also may exhibit the greatest toxicity relative to other contaminants observed in the Brown's Wash ground water.

As can be seen in Table 6.1, if the alluvial ground water were used for drinking water, the nitrate levels would be potentially lethal for infants. Persistent severe diarrhea leading to dehydration and death could result from potential exposure to sulfate levels in ground water if this ground water were ingested, especially by infants. Although uranium levels substantially exceeded EPA health advisory levels, they do not appear to be associated with adverse health effects in potentially exposed humans.

\subsubsection{Upper Cedar Mountain aquifer ground water potential use}

In this section, the expected intake ranges are correlated to potential health effects from these levels of exposure if contaminated ground water from the Upper Cedar Mountain aquifer were used as drinking water.

The results from the exposure assessment showing either the highest intake-tobody-weight ratios (i.e., highest doses) or the toxicologically most sensitive group are used to evaluate potential health effects for noncarcinogens. For arsenic, manganese, molybdenum, selenium, sodium, uranium, and vanadium, 
Table 6.1 Potential adverse health effects from ingestion of nitrate, sulfate, and uranium in the Brown's Wash alluvium ground water, Green River, Utah, site

\begin{tabular}{lcccc}
\hline Contaminant & $\begin{array}{c}\text { Maximum observed } \\
\text { concentration } \\
(\mathrm{mg} / \mathrm{L})\end{array}$ & $\begin{array}{c}\text { NOAEL } \\
\text { (mg/L) }\end{array}$ & $\begin{array}{c}\text { LOAEL } \\
\text { (mg/L) }\end{array}$ & $\begin{array}{c}\text { Severe toxicity } \\
\text { level } \\
\text { (mg/L) }\end{array}$ \\
\hline Nitrate & 440 & $44^{\mathrm{b}}$ & $\mathrm{NA}$ & $219^{\mathrm{C}}$ \\
Sulfate & 6890 & $160^{\mathrm{d}}$ & $300^{\mathrm{e}}$ & $688^{f}$ \\
Uranium & 1.96 & $0.03^{\mathrm{g}}$ & $\mathrm{NA}$ & $\mathrm{NA}$ \\
& & $0.1^{\mathrm{h}}$ & $\mathrm{NA}$ & $\mathrm{NA}$ \\
\hline
\end{tabular}

aBrown's Wash alluvium downgradient wells 702, 704, 705, 708, and 808 .

${ }^{b}$ Concentration estimated based on the EPA oral RfD of $7 \mathrm{mg} / \mathrm{kg}$-day (Section 5.1.4).

${ }^{c}$ Concentration estimated based on a lethal dose for infants of $35 \mathrm{mg} / \mathrm{kg}$-day (as discussed in Section 5.1.4), assuming an ingestion rate of $0.64 \mathrm{~L} /$ day and a body weight of $4 \mathrm{~kg}$.

${ }^{d}$ Concentration estimated based on an NOAEL of $25 \mathrm{mg} / \mathrm{kg}$-day for infants (as discussed in Section 5.1.71, assuming an ingestion rate of $0.64 \mathrm{~L} /$ day and a body weight of $4 \mathrm{~kg}$.

${ }^{\text {e }}$ Concentration estimated based on an exposure dose of $50 \mathrm{mg} / \mathrm{kg}$-day associated with diarrhea in infants (as discussed in Section 5.1.7), assuming an ingestion rate of $0.64 \mathrm{~L} /$ day and a body weight of $4 \mathrm{~kg}$.

${ }^{f}$ Concentration estimated based on an exposure dose of $110 \mathrm{mg} / \mathrm{kg}$-day associated with severe toxicity in infants (as discussed in Section 5.1.7), assuming an ingestion rate of $0.64 \mathrm{~L} / \mathrm{day}$ and a body weight of $4 \mathrm{~kg}$.

9EPA health advisory level for a 10-kg child and 10-day exposure duration.

$h_{E P A}$ health advisory level for a 70-kg adult and lifetime exposure.

NA - Reliable data are not available.

the highest intake-per-body-weight group is children 1 to 10 years old. For nitrate and sulfate, infant exposures are used to evaluate health risks, because infants are the toxicologically sensitive population.

The most significant potential health risks associated with drinking contaminated ground water from the Upper Cedar Mountain aquifer at the Green River former uranium processing site are from nitrate, sulfate, and sodium. Adverse health effects from these contaminants would be expected even after short-term exposures.

As can be seen in Figure 6.1, if contaminated ground water were used for drinking water, nearly 50 percent of the expected nitrate exposures would be above the potentially lethal level for infants. Some degree of methemoglobinemia would be expected with any infant consumption of ground water, with more than 70 percent of the predicted exposure range falling above the severe toxicity level. However, 99 percent of the predicted exposure range would fall below the fatal dose level $(116 \mathrm{mg} / \mathrm{kg}$-day) documented for an adult human. 


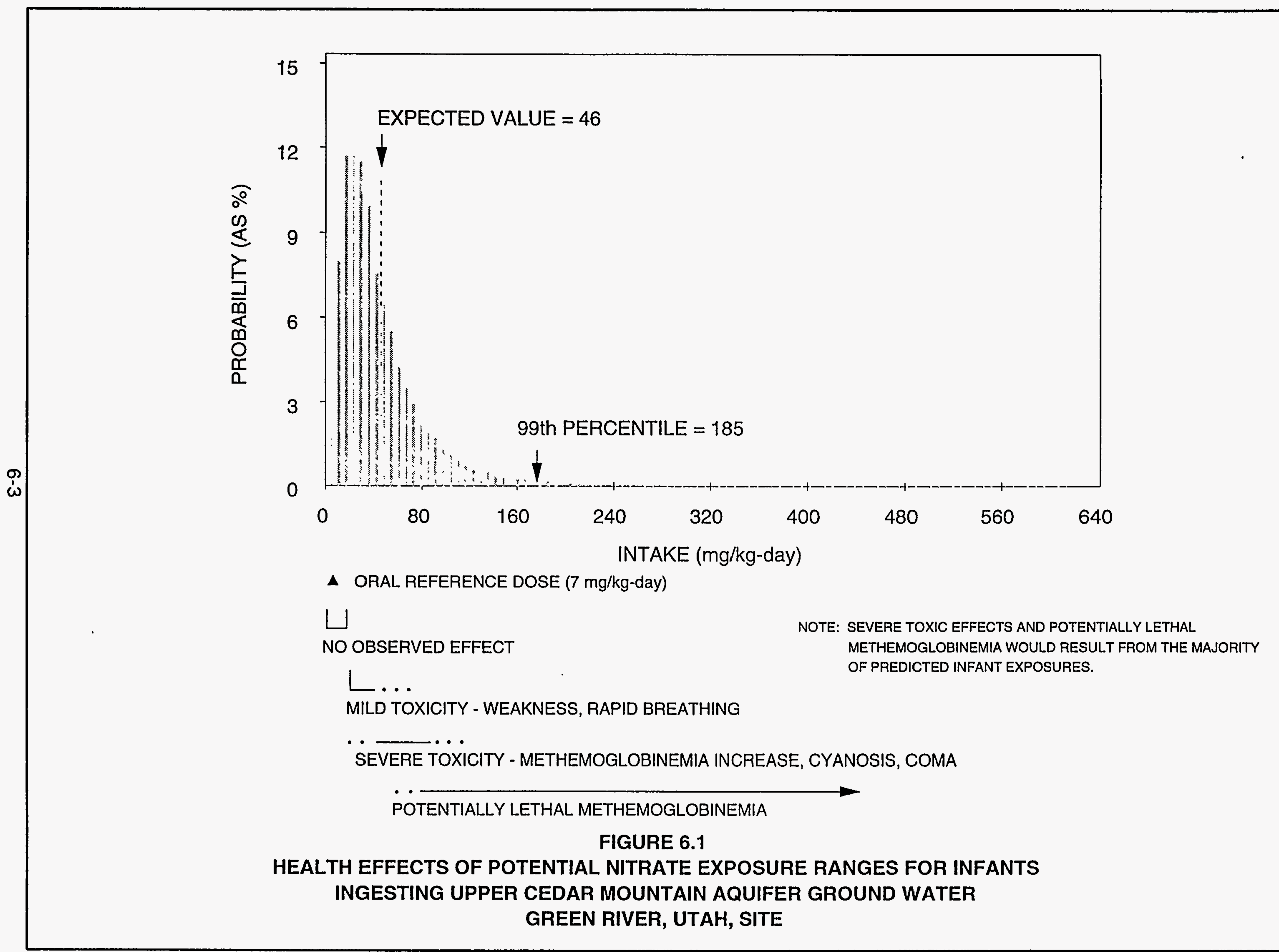


The levels of nitrate associated with lethal cases of methemoglobinemia vary considerably. A major cofactor in nitrate toxicity may be the presence of bacterial contamination of the ground water, thus increasing reduction of nitrate to nitrite in the gut. This factor has not been evaluated in Green River ground water. A second significant factor appears to be that infants prone to gastrointestinal distress seem to be more sensitive to the toxic effects of nitrates. For this reason, it is possible that gastrointestinal effects associated with sulfate exposures could increase nitrate toxicity. However, it is also possible that sulfate-induced diarrhea could decrease the intestinal content of nitrate-reducing bacteria, making nitrate less toxic. Likewise, these high sulfate concentrations may cause the water to be unpalatable to infants, thus reducing their exposure.

Figure 6.2 shows that almost 100 percent of the exposure distribution for sulfate is above the range where mild diarrhea would be expected, and about 75 percent of the exposures are above the range of severe diarrhea, which can lead to dehydration and death. Because the predicted nitrate and sulfate toxicity from drinking water is so severe, and because this is the only exposure pathway associated with toxicity for infants, any additive contribution from other dietary and environmental sources would not alter the interpretation of health risks.

The exposure distributions of nitrate and sulfate for infants are based on tap water intake rates across a population that includes breast-fed and cannedformula-fed infants. Infants consuming powdered formula reconstituted with well water would be in the upper percentiles of these exposure distributions and could be at higher risk of severe diarrhea and methemoglobinemia. Further, these effects would be expected after very short-term exposures.

Chronic sodium exposure would be associated with the development of hypertension in children as well as in adults. As can be seen in Figure 6.3, 75 percent of the exposure distribution for sodium is above the upper level of average known sodium dietary intake, and 99 percent of this distribution is above the threshold level producing hypertension in humans. Although solutions with physiologically balanced electrolyte concentrations containing high levels of sodium have been used to alleviate diarrhea-induced hyponatremia, it is not possible to predict the net effect of simultaneous chronic ingestion of sodium and sulfate at high concentrations without balanced electrolytes.

For manganese (Figure 6.4), more than 99 percent of the exposure distribution falls above the EPA oral RfD derived from drinking water consumption studies, and above the threshold level of mild neurological symptoms in adults. As discussed in Section 5.1.2, infants may be more sensitive to manganese toxicity than children and adults. Therefore, toxic effects may appear in infants at lower levels than in the toxicity ranges presented here.

For selenium (Figure 6.5), almost 80 percent of the exposure distribution is above the EPA-derived oral RfD, and about 30 percent of this exposure 


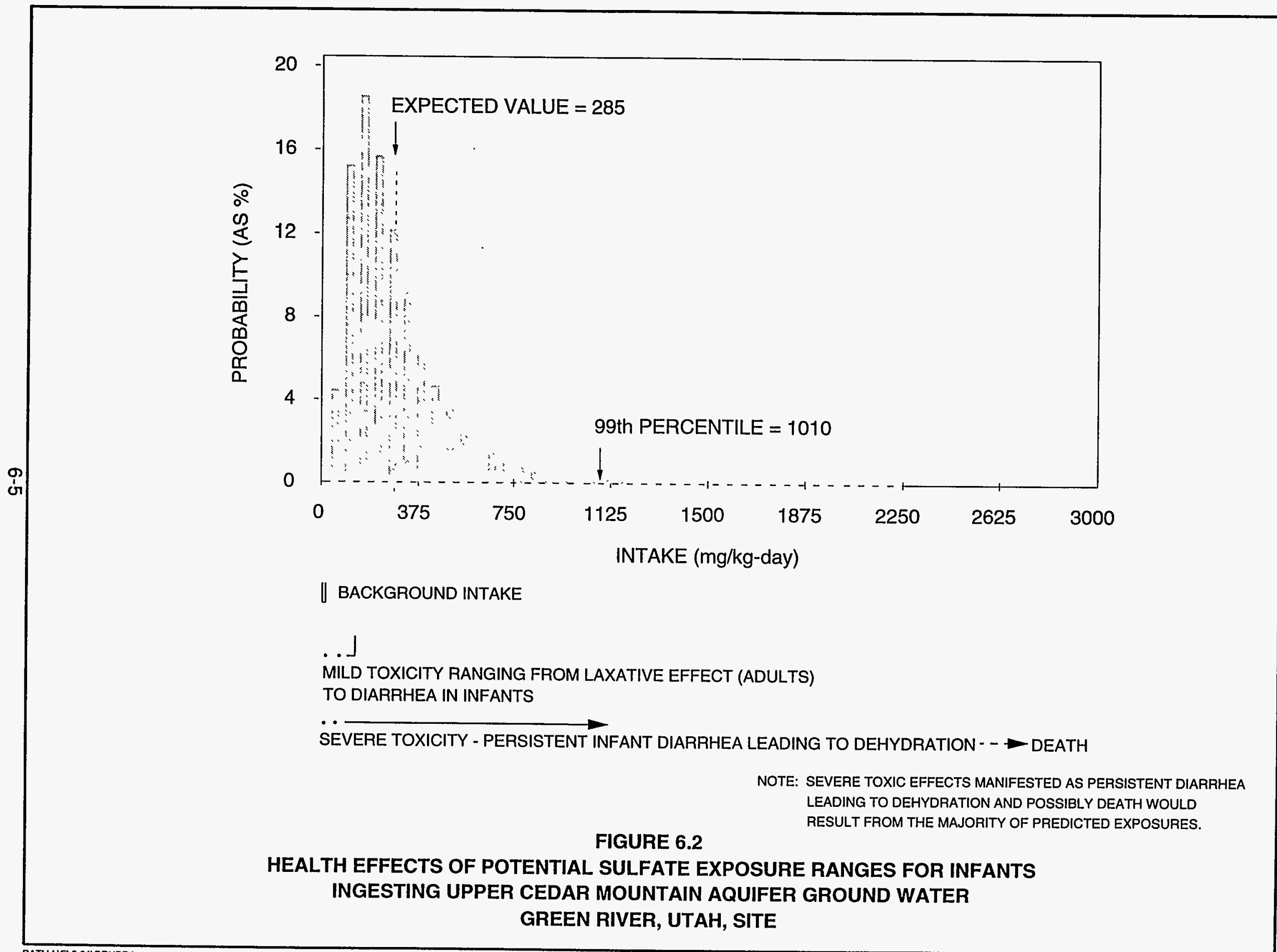




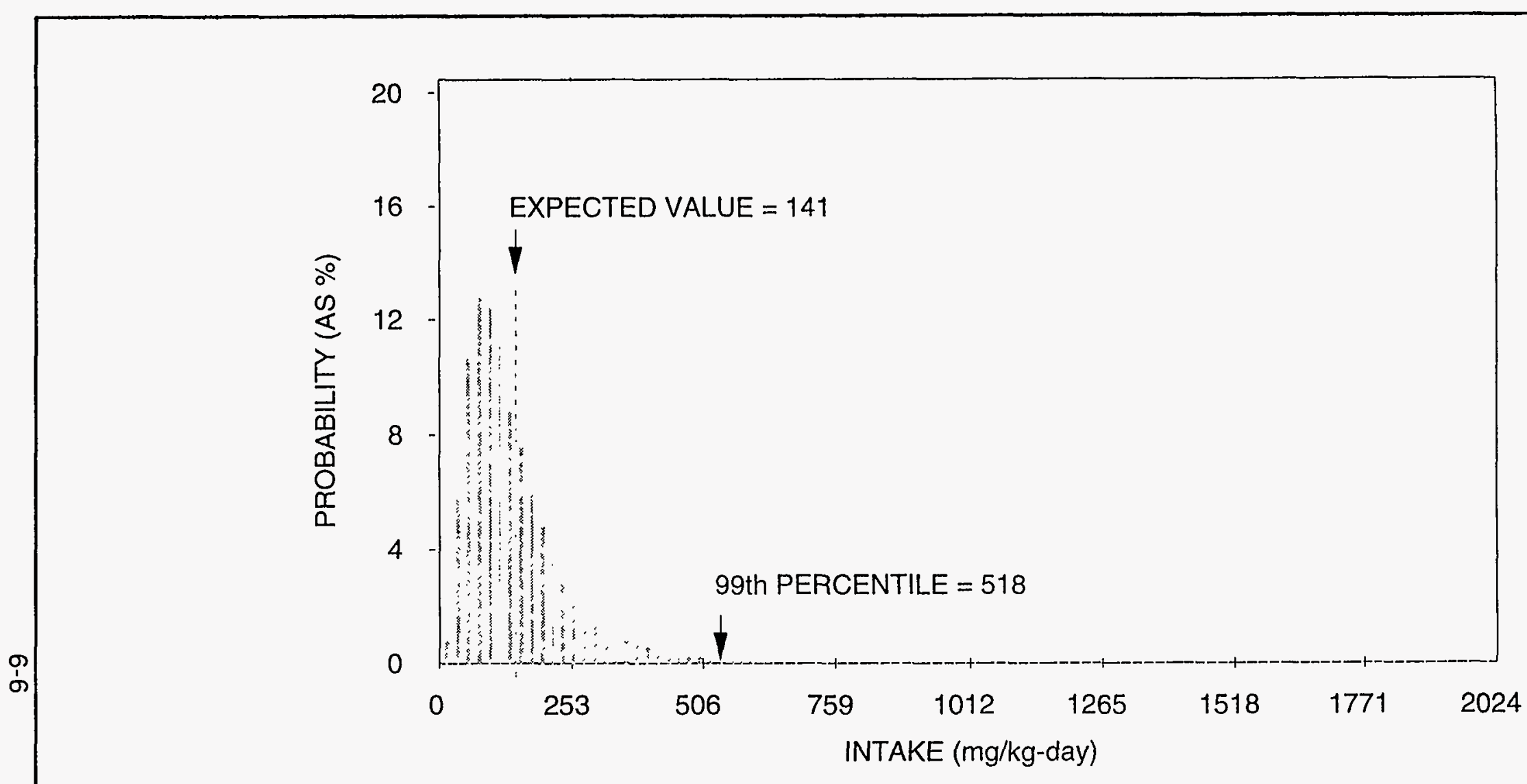

$\bigcup$ BACKGROUND INTAKE LEVELS FROM DRINKING INTAKE

- NUTRITIONAL REQUIREMENT

- NRC RECOMMENDED LIMIT FOR DIETARY INTAKE

$\cdots-\cdots$

DIETARY INTAKE LEVELS

HYPERTENSION AND KIDNEY

IMPAIRMENT MAY OCCUR

IN HUMANS

NOTE: HYPERTENSION WOULD RESULT FROM THE PREDICTED RANGE OF EXPOSURES. THE MAJORITY OF PREDICTED CHILDREN'S EXPOSURES IS ABOVE THE UPPER RANGE OF AN AVERAGE DIETARY SODIUM INTAKE.

FIGURE 6.3

HEALTH EFFECTS OF POTENTIAL SODIUM EXPOSURE RANGES FOR CHILDREN INGESTING UPPER CEDAR MOUNTAIN AQUIFER GROUND WATER

GREEN RIVER, UTAH, SITE 


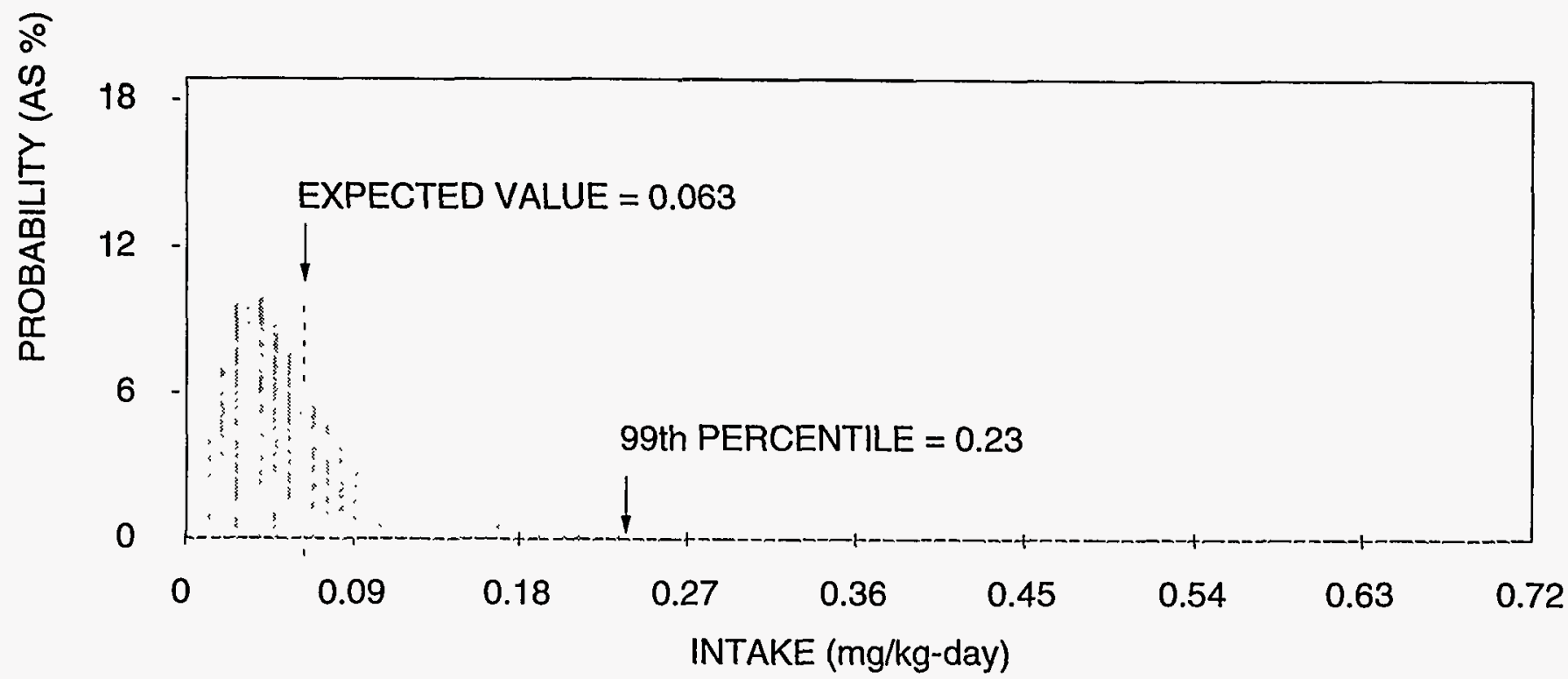

I BACKGROUND DRINKING WATER INTAKE

DIETARY INTAKE FROM FOOD

A EPA RfD - DRINKING WATER (0.005 mg/kg-day)

NOTE: MILD NEUROLOGICAL SYMPTOMS WOULD RESULT FROM THE MAJORITY OF PREDICTED EXPOSURES.

EARLY NEUROLOGICAL SYMPTOMS

PARKINSON-LIKE EFFECTS

FIGURE 6.4

HEALTH EFFECTS OF POTENTIAL MANGANESE EXPOSURE RANGES FOR CHILDREN INGESTING UPPER CEDAR MOUNTAIN AQUIFER GROUND WATER

GREEN RIVER, UTAH, SITE 


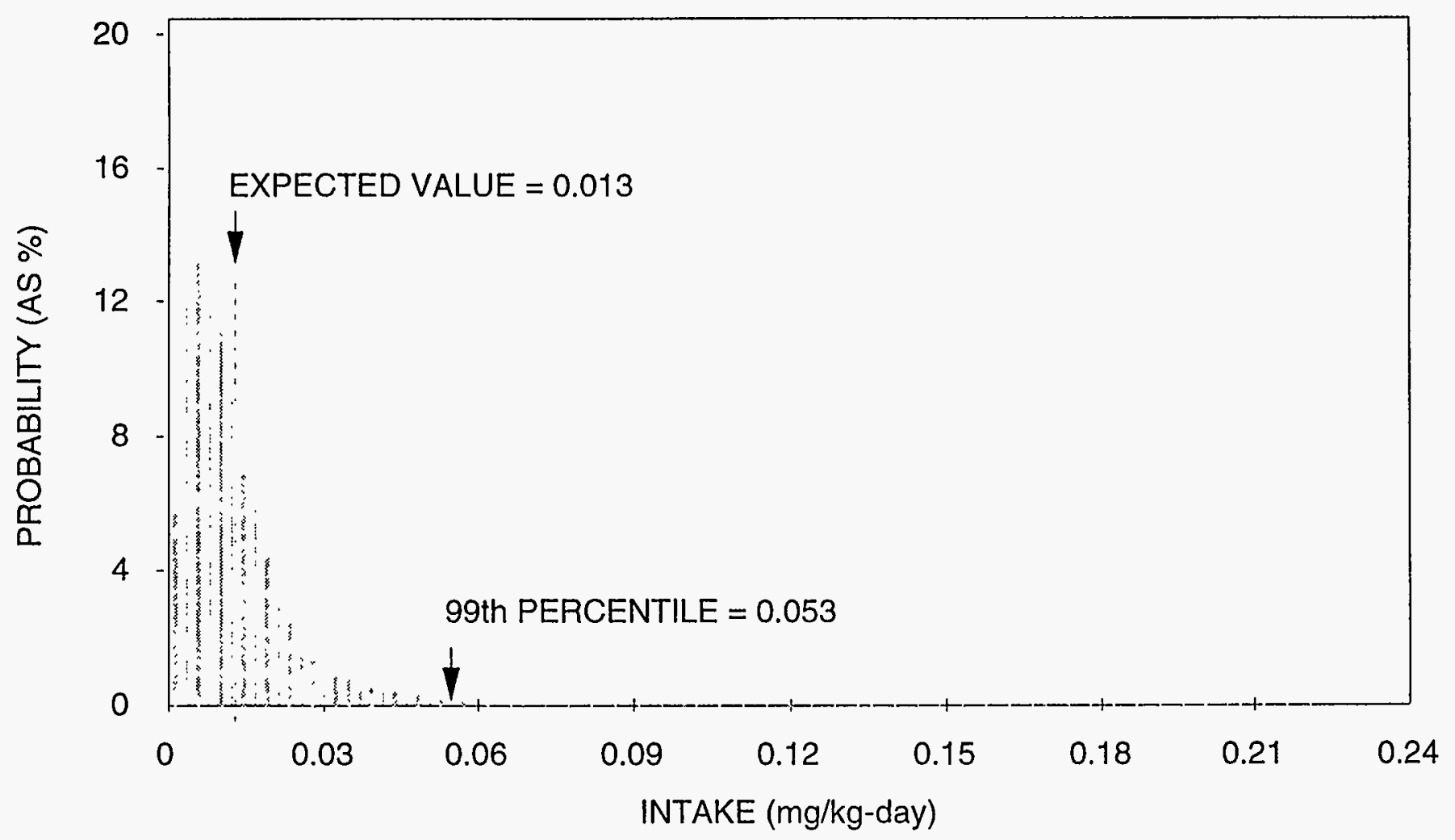

U NUTRITIONAL INTAKE LEVELS

Ц DIETARY INTAKE LEVELS

A ORAL RfD $(0.005 \mathrm{mg} / \mathrm{kg}$-day)

...

NO OBSERVED EFFECT LEVEL

\section{L}

MILD TOXICITY - NAIL AND HAIR BRITTLENESS/LOSS
NOTE: MILD TOXICITY MANIFESTED AS HAIR AND NAIL LOSS AND/OR BRITTLENESS WOULD RESULT FROM LESS THAN 40 PERCENT OF PREDICTED EXPOSURES.

\section{FIGURE 6.5}

HEALTH EFFECTS OF POTENTIAL SELENIUM EXPOSURE RANGES FOR CHILDREN INGESTING UPPER CEDAR MOUNTAIN AQUIFER GROUND WATER GREEN RIVER, UTAH, SITE 
distribution falls above the threshold level producing symptoms of mild toxicity (nail and hair brittleness or loss).

For the remaining contaminants of potential concern at Green River, few if any adverse health effects are anticipated from chronic ground water ingestion. For arsenic (Figure 6.6), 70 percent of the exposure distribution is above the EPA oral RfD, but nearly 100 percent falls below the observed threshold level of skin pathology in potentially exposed humans. Arsenic and selenium together may reduce their respective toxicity; however, some methylated metabolites of selenium can increase arsenic toxicity.

Eighty percent of the predicted exposure range for molybdenum (Figure 6.7) is below the EPA-derived oral RfD, and more than 50 percent falls within the nutritional intake range. Less than approximately 10 percent of predicted molybdenum exposures from drinking water ingestion would be associated with symptoms of mild toxicity, including increased production of uric acid and mineral imbalance resulting from increased copper excretion.

For uranium (Figure 6.8), nearly 100 percent of the exposure range falls above the EPA oral RfD. At the upper 1 percent of predicted exposures, reversible kidney impairment has occurred in humans. However, more than 99 percent of the exposure distribution for uranium is below levels where any toxic effects have been observed in humans or in animal studies. This apparent discrepancy between the oral RfD and the observed toxicity levels occurs largely because there is little toxicity information for uranium in humans. Uranium has not been demonstrated to serve a beneficial purpose in biological systems; therefore, unlike nutrient metals, it is difficult to define a threshold level of toxicity. Because of these uncertainties, the EPA has set a conservative oral RfD for uranium.

For vanadium (Figure 6.9), more than 90 percent of the exposure distribution falls below the EPA-derived oral RfD. No toxic effects have been observed in humans at any of the predicted exposure levels.

The less than 4 percent additional exposure contribution calculated for other pathways in Section 4.0 would not significantly alter the predicted risk for any contaminant discussed here, even if these other pathways are considered as a sole source of exposure. Therefore, these pathways will not be evaluated further.

\subsection{POTENTIAL CARCINOGENIC HEALTH EFFECTS}

All uranium isotopes are radioactive and, as such, are considered potential carcinogens. Although natural uranium has not been demonstrated to cause cancer in humans or animals following ingestion exposures, the estimates of increased lifetime cancer risk are based on the cancer SF developed by the EPA. For the Brown's Wash alluvium, estimated excess lifetime cancer risk due to potential ingestion of ground water contaminated with uranium-234 and 


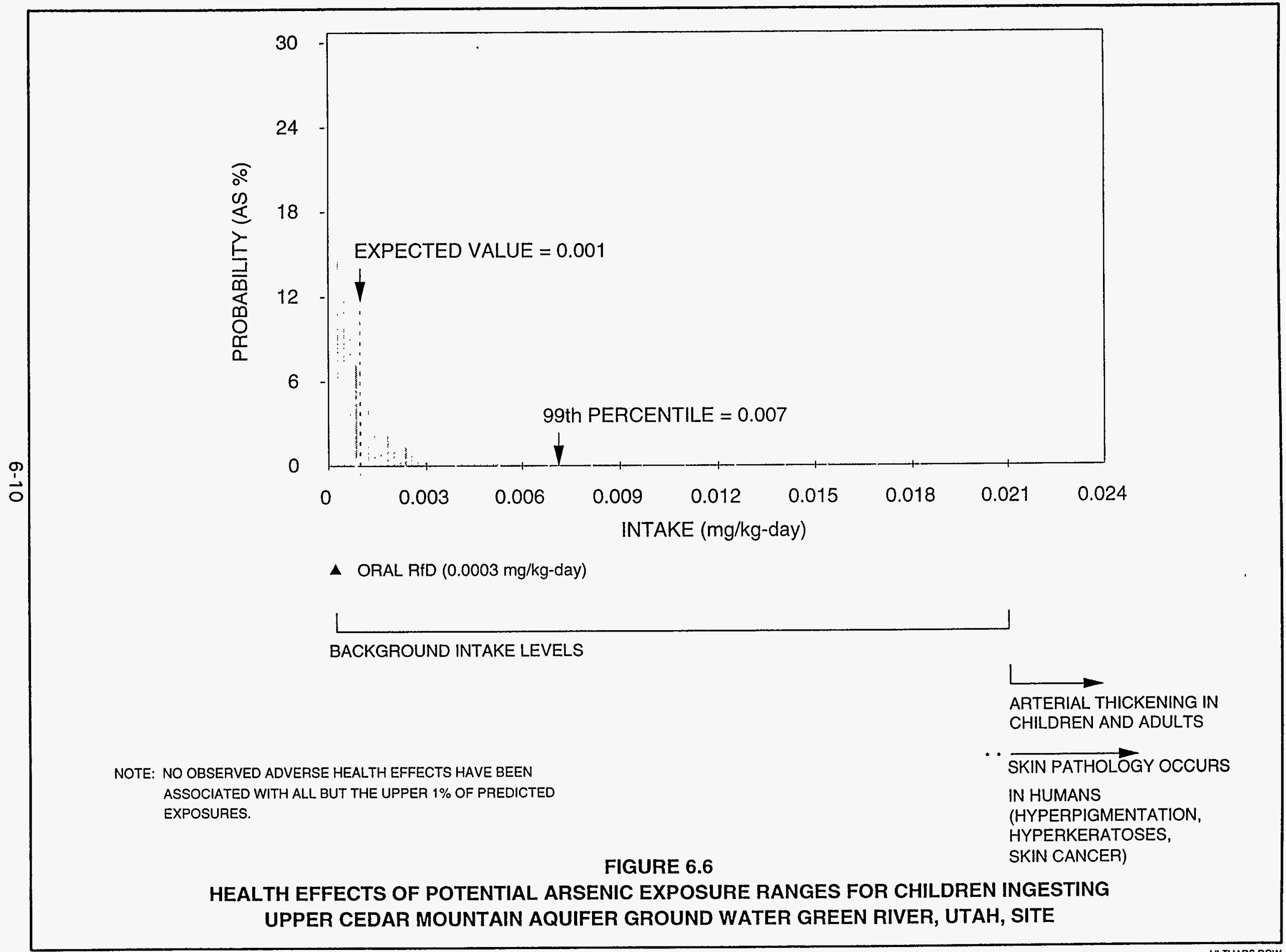




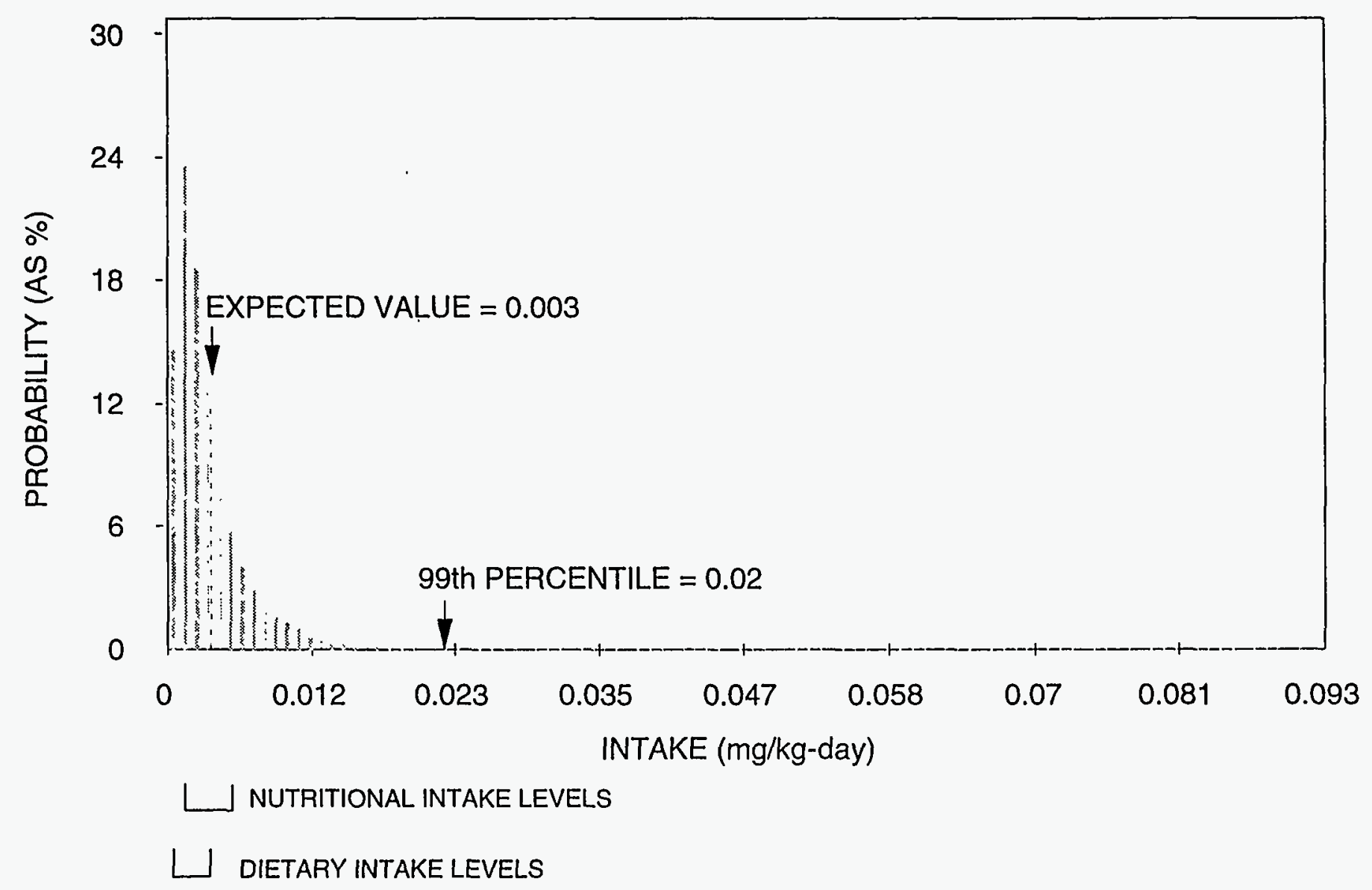

\ ORAL RfD (0.005 mg/kg-day)

NOTE: $90 \%$ OF THE PREDICTED EXPOSURES FALL WITHIN THE NO-OBSERVED-HEALTH-EFFECTS RANGE.

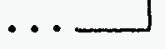

NO OBSERVED EFFECT LEVEL

MILD TOXICITY - INCREASED COPPER EXCRETION AND

INCREASED URIC ACID SYNTHESIS - - - $\rightarrow$ GOUT

FIGURE 6.7

HEALTH EFFECTS OF POTENTIAL MOL YBDENUM EXPOSURE RANGES FOR CHILDREN

INGESTING UPPER CEDAR MOUNTAIN AQUIFER GROUND WATER

GREEN RIVER, UTAH, SITE 


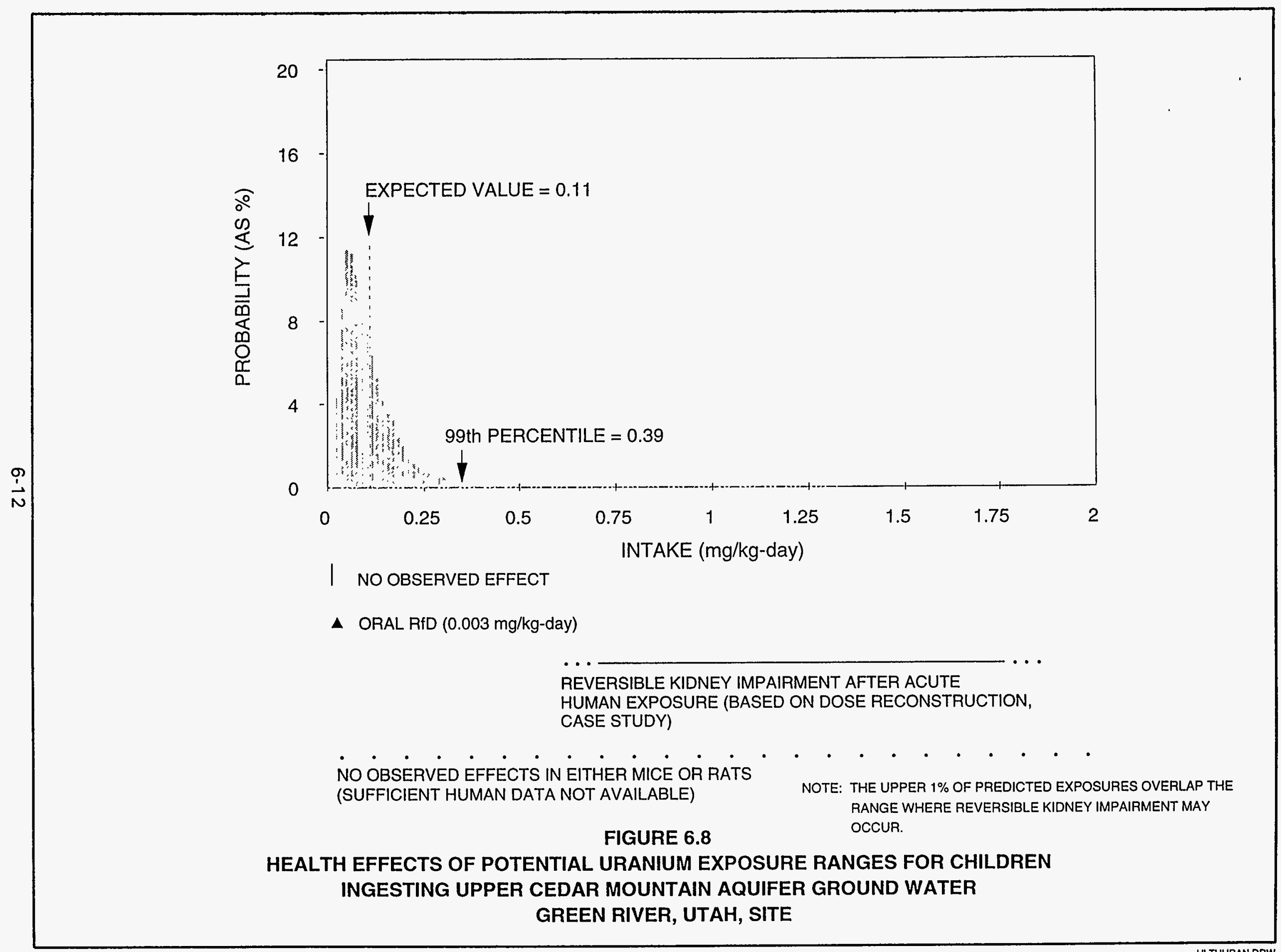




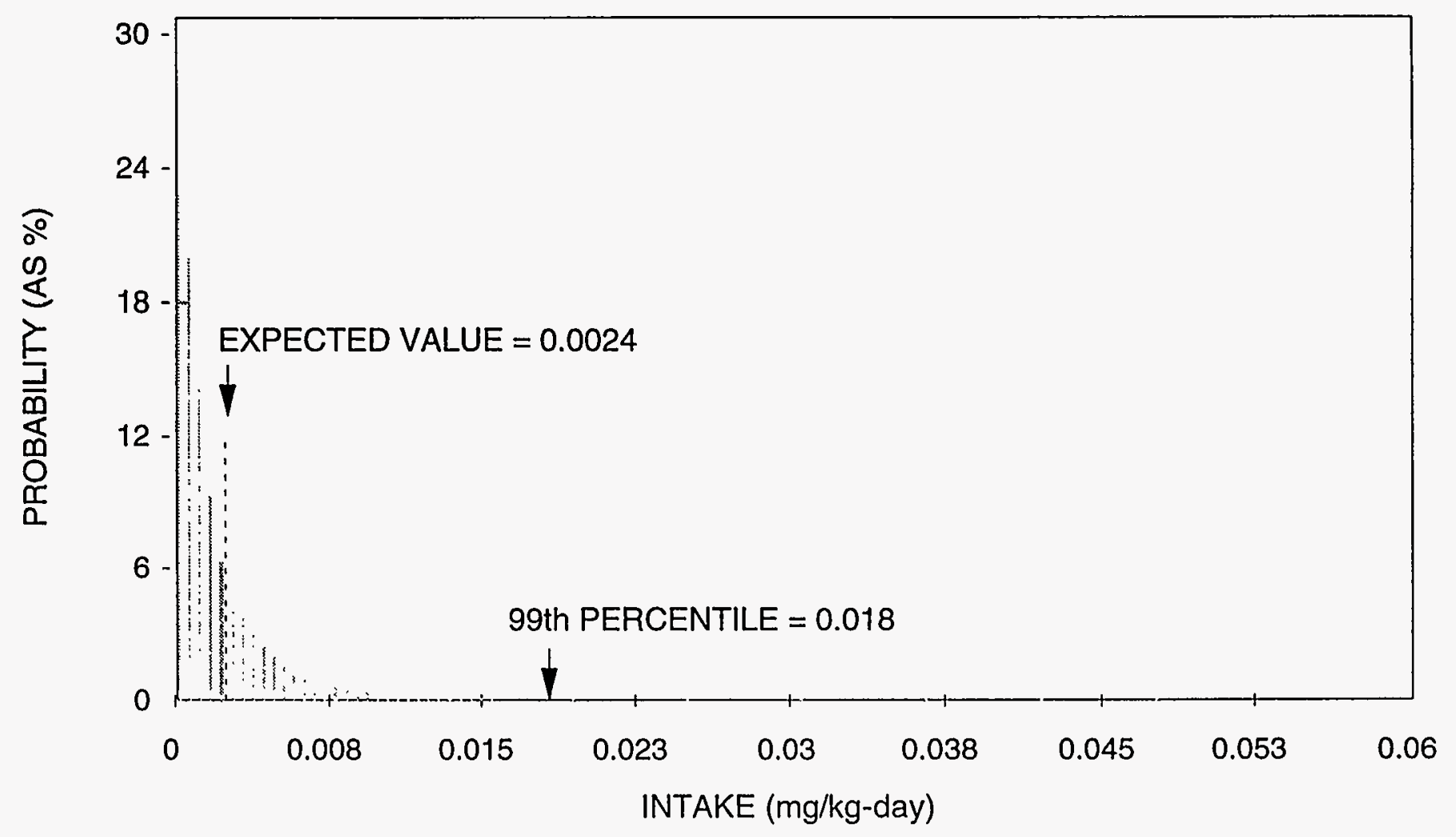

A ORAL RfD - DRINKING WATER $(0.007 \mathrm{mg} / \mathrm{kg}$-day)

$$
\text { L }
$$

DIETARY INTAKE LEVELS

NOTE: NO OBSERVED ADVERSE HEALTH EFFECTS HAVE BEEN ASSOCIATED WITH THE PREDICTED RANGE OF EXPOSURES.

FIGURE 6.9

HEALTH EFFECTS OF POTENTIAL VANADIUM EXPOSURE RANGES FOR CHILDREN INGESTING UPPER CEDAR MOUNTAIN AQUIFER GROUND WATER

GREEN RIVER, UTAH, SITE 
uranium-238 and longer-lived uranium decay products is 9 in 10,000 . This exceeds the EPA's National Contingency Plan (NCP) guidance (developed for Superfund sites) of maximum increased cancer risk of 1 in 10,000 (Table 6.2).

Table 6.2 Carcinogenic risk for the Brown's Wash alluvium ground water ingestion pathway at the Green River, Utah, site

\begin{tabular}{lcccc}
\hline $\begin{array}{c}\text { Contaminant of } \\
\text { potential concern }\end{array}$ & $\begin{array}{c}\text { Exposure point } \\
\text { concentration } \\
\text { (pCi/L) }\end{array}$ & $\begin{array}{c}\text { Intake } \\
\text { (pCi/lifetime) }\end{array}$ & $\begin{array}{c}\text { Ingestion SF } \\
(p C i)^{-1}\end{array}$ & Lifetime risk $^{\text {If }}$ \\
\hline $\begin{array}{l}\text { Uranium- } \\
234 / 238^{\mathrm{b}}\end{array}$ & 1345 & $47,075,000$ & $1.6 \mathrm{E}-11$ & $8 \mathrm{E}-04$ \\
Lead-210 & 4.4 & 154,000 & $5.1 \mathrm{E}-10$ & $8 \mathrm{E}-05$ \\
Polonium-210 & 0.4 & 14,000 & $1.5 \mathrm{E}-10$ & $2 \mathrm{E}-06$ \\
Radium-226 & 0.5 & 17,500 & $1.2 \mathrm{E}-10$ & $2 \mathrm{E}-06$ \\
Thorium-230 & 3.1 & 108,500 & $1.3 \mathrm{E}-11$ & $1 \mathrm{E}-06$ \\
Total: & & & & $9 \mathrm{E}-04$ \\
\hline
\end{tabular}

a Maximum observed concentration measured in downgradient alluvial wells $702,704,705,708$, 808; filtered samples; 1986-1988.

buranium-234 and uranium-238 combined; $1 \mathrm{mg}$ uranium is assumed to equal $686 \mathrm{pCi}$. Ingestion rate: $2 \mathrm{~L} /$ day. Exposure frequency: 350 days/year.

Exposure duration: 50 years.

If contaminated ground water in the Upper Cedar Mountain aquifer were used as drinking water, the risk of skin cancer could increase as a result of chronic exposure to detected arsenic levels (Figure 6.10). This evaluation is based on the EPA oral SF of $1.8\left(\mathrm{mg} / \mathrm{kg}^{-d a y}\right)^{-1}$ for skin cancer development. About 8 percent of the exposure distribution for ingested arsenic by adults falls within the NCP guidance. The expected exposure value would result in an excess lifetime cancer risk of 5 in 10,000.

The exposure distribution for uranium-234 and uranium-238 intakes from the most contaminated wells in the Upper Cedar Mountain aquifer and potential lifetime carcinogenic risk associated with these exposures are shown in Figure 6.11. The entire ingestion exposure distribution of uranium for the Upper Cedar Mountain falls above the NCP guidance for maximum increased lifetime cancer risk of 1 in 10,000. The expected exposure value results in an excess lifetime cancer risk of 7 in 10,000, and the upper 1 percent of exposures would be expected to result in an excess lifetime cancer risk of 2 in 1000. The distribution presented here is thought to be conservative because it is based on a cumulative 50-year exposure duration. As discussed previously, this exposure duration is probably appropriate, but ground water uranium concentrations 

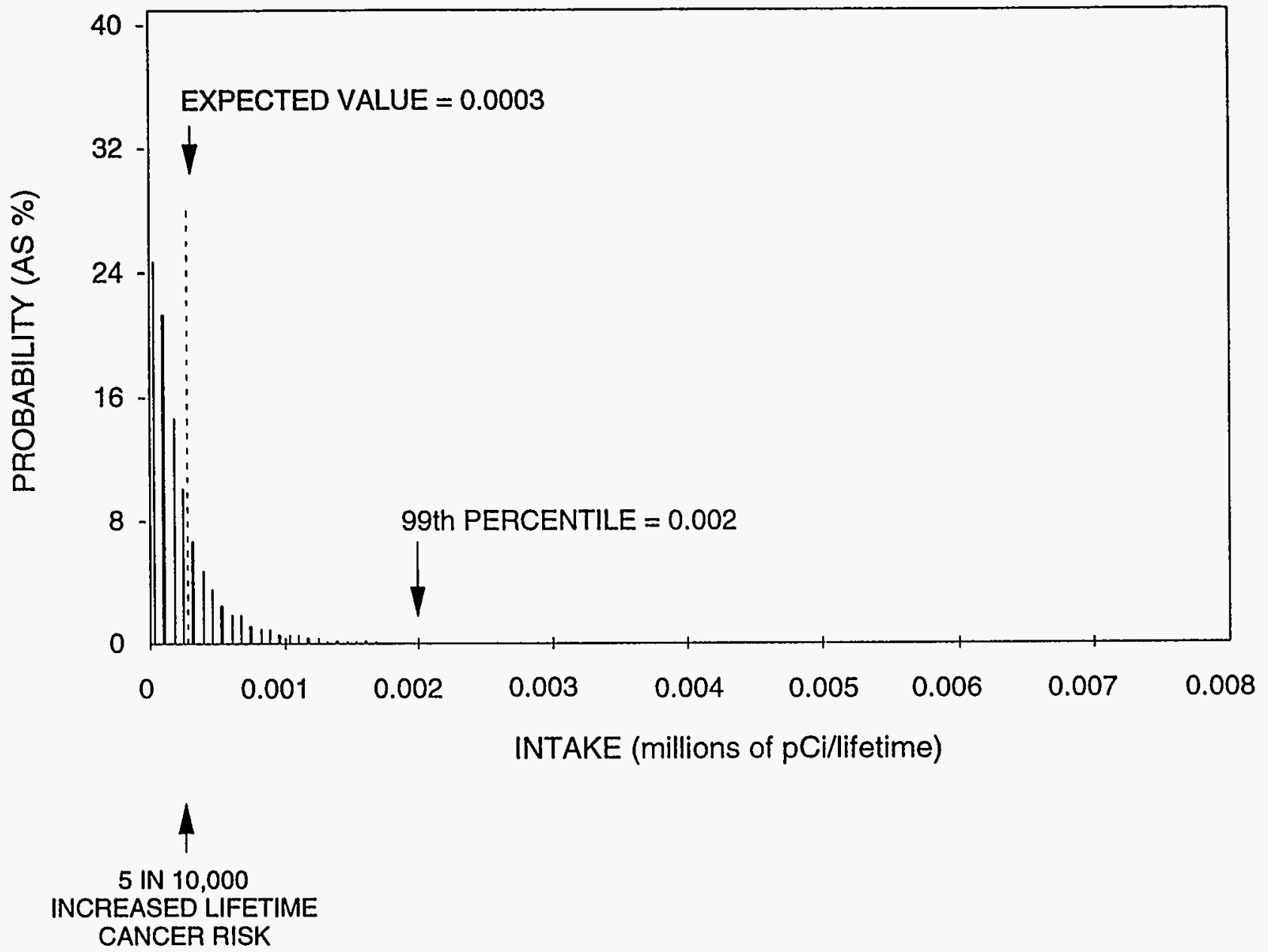

NOTE: THE AVERAGE PREDICTED EXPOSURE IS RELATED TO AN INCREASED CANCER RATE OF $0.005 \%$.

FIGURE 6.10

INCREASED LIFETIME CANCER RISK ASSOCIATED WITH POTENTIAL ARSENIC EXPOSURE RANGES FOR ADULTS INGESTING CONTAMINATED UPPER CEDAR MOUNTAIN AQUIFER GROUND WATER GREEN RIVER, UTAH, SITE 


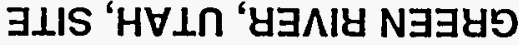

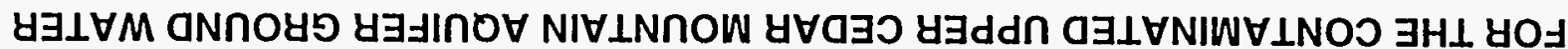

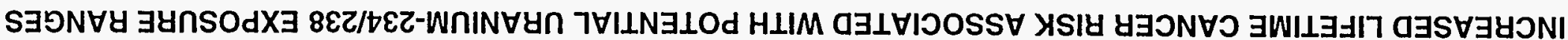

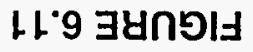

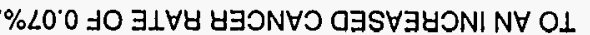

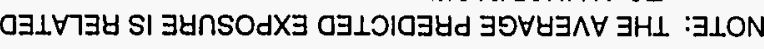

YSIY UEON $\forall O$

$\exists W I \perp \exists \exists 17$ O $000^{\prime} \mathrm{N} \mathrm{NI}$ L

YSSI $Y \exists O N \forall O$ $\exists W I \perp \exists \exists I 7$ व $\triangle \triangle \exists \exists Y O N$ $000^{\circ} \div \mathrm{NI} Z$

$\downarrow$

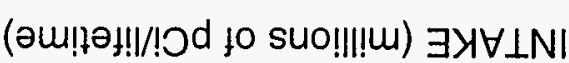

$\downarrow$

YSIY GJON

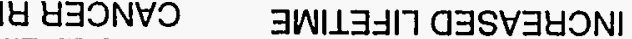

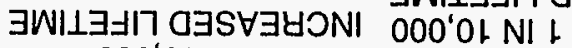
$000^{\circ} 0 \mathrm{~L} \mathrm{NI} L$

$\downarrow$

1

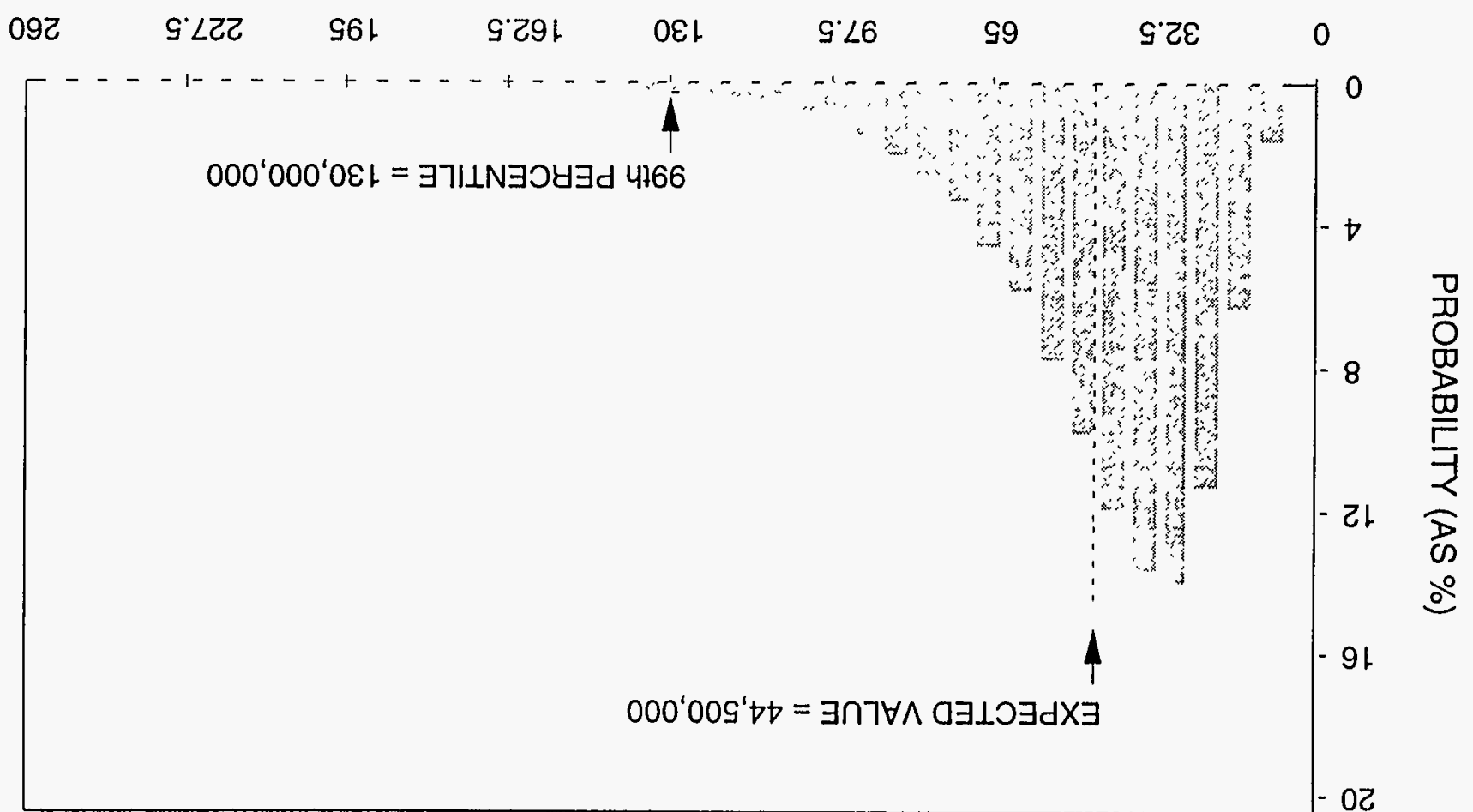


resulting from processing at this site would be expected to decline following tailings stabilization. Therefore, this distribution should overestimate risk.

Since uranium decays to longer-lived radioactive progeny, these progeny were evaluated for carcinogenic risk. Lead-210, polonium-210, and thorium-230 have been measured only twice each in the plume wells 701, 703, and 581. They have never been measured in the background wells or in plume wells 562,807 , 813 , and 816 . Thus, measurements of radionuclides could not be compared with background levels. Nevertheless, the estimated carcinogenic risks from radionuclides other than uranium-234 and uranium-238 are shown in Table 6.3.

Table 6.3 Carcinogenic risk for the Upper Cedar Mountain aquifer ground water ingestion pathway at the Green River, Utah, site

\begin{tabular}{lcccc}
\hline $\begin{array}{c}\text { Contaminant of } \\
\text { potential concern }\end{array}$ & $\begin{array}{c}\text { Exposure point } \\
\text { concentration } \\
(\mathrm{pCi} / \mathrm{L})\end{array}$ & $\begin{array}{c}\text { Intake } \\
\text { (pCi/lifetime) }\end{array}$ & $\begin{array}{c}\text { Ingestion slope } \\
\text { factor } \\
(\mathrm{pCi})^{-1}\end{array}$ & Lifetime risk \\
\hline $\begin{array}{c}\text { Radionuclides } \\
\text { Lead-210 }\end{array}$ & 13 & 455,000 & $5.1 \mathrm{E}-10$ & $2 \mathrm{E}-04$ \\
Polonium-210 & 1.4 & 49,000 & $1.5 \mathrm{E}-10$ & $7 \mathrm{E}-06$ \\
Radium-226 & $4.2^{\mathrm{b}}$ & 147,000 & $1.2 \mathrm{E}-10$ & $2 \mathrm{E}-05$ \\
Thorium-230 & 8.4 & 294,000 & $1.3 \mathrm{E}-11$ & $4 \mathrm{E}-06$ \\
Total & & & & $2 \mathrm{E}-04$ \\
\hline
\end{tabular}

a Maximum observed concentration; filtered data; $1986-1988$.

b Maximum observed concentration; filtered data; 1989-1993.

Ingestion rate: 2 L/day.

Exposure frequency:. 350 days/year.

Exposure duration: 50 years.

Excess lifetime cancer risk associated with radionuclides for the Upper Cedar Mountain ground water ingestion is twice the upper limit of the range recommended as acceptable in the NCP.

\subsection{LIMITATIONS OF THE HUMAN HEALTH RISK EVALUATION}

The following potential limitations apply to interpretations of this human health risk evaluation:

- Subpopulations that might have increased sensitivity are not specifically addressed on the graphs. 
- Some individuals may be more sensitive to the toxic effects of certain constituents for reasons that have not been determined.

- Data may not always be sufficient to accurately determine all potential adverse health effects due to lack of human testing or testing of dose ranges other than those expected at this site.

- Although plume movement has been evaluated hydrologically and geochemically, it is possible that the monitoring locations sampled have failed to reach the most contaminated portion of the plume.

- Only the drinking water exposure pathway has been considered in depth; other pathways have been screened only to determine their relative contribution.

The evaluation presented here has considered these limitations and compensated wherever possible by presenting toxicity ranges and probabilistic exposure assessments rather than point estimates to incorporate as much variability as could be reasonably defined. The impact of these potential limitations is discussed more fully in Section 8.2. 


\subsection{ECOLOGICAL AND LIVESTOCK RISK EVALUATION}

The objectives of this section are to assess the potential for site-related contaminants to adversely affect existing biological communities, livestock grazing, and other agricultural practices in the site area. Currently, the EPA has no guidance for quantifying potential ecological impacts of the release of hazardous constituents. However, the EPA has developed a qualitative approach to be used in ecological risk evaluations (EPA, 1989b). As part of this qualitative approach, the EPA recommends that ecological assessments be conducted in a phased approach, which ensures the most effective use of resources yet results in all necessary work being conducted (EPA, 1992b). This approach consists of four increasingly complex phases: identifying potentially exposed habitats; collecting chemistry data; collecting biological samples; and conducting toxicity testing. If the initial habitat inspection and the media sample analysis indicate that there is no, or very low, potential for ecological risk, the assessment will likely be complete. If the early phases of the assessment indicate that the contaminants may be adversely affecting ecological receptors, a higher level of analysis may be warranted.

The ecological risk assessment at the Green River site consists of the first two phases of EPA's approach, because habitats may have been affected and water chemistry data collected for many years are available. The existing water quality data for the last 10 years, plus additional limited water quality and sediment data collected for this assessment, were used to prepare this assessment. This qualitative approach provides a screening level assessment of the risks associated with potential exposure to contaminated media at the site.

It is often difficult to determine whether contaminants have affected the biological component of an ecosystem and to predict whether observed effects will damage the ecosystem. However, sampling of environmental media such as surface water can be used to assess the possibility of an ecological risk occurring. For such an ecological risk to occur, there must be both a source of contamination and a pathway for this contamination to reach the biological communities. The remaining sections identify the following:

- Areas of contamination and the potential pathways by which this contamination may be entering the aquatic and terrestrial biological communities at the Green River site.

- Potential ecological receptors at the site.

- Contaminants of potential concern.

- Potential hazards the contaminants of concern may pose to the ecological resources, livestock, and agricultural crops.

\subsection{EXPOSURE PATHWAYS}

The Green River tailings pile covered 8 ac ( $3 \mathrm{ha}$ ) in the floodplain of Brown's Wash; an additional 40 ac (16 ha) were contaminated with windblown tailings. This included windblown tailings on the north side of Brown's Wash. No 
contaminated material was identified within Brown's Wash and no cleanup was required (DOE, 1991).

Ground water was contaminated beneath the Green River site during and after the operation of the uranium processing facility. The degree and extent of this ground water contamination are summarized in Section 3.0. A potential pathway for this contamination to reach the environment is via deep-rooted plants transporting contaminants to the surface directly out of this aquifer. In addition, contaminated ground water from the Brown's Wash alluvium and/or the Upper Cedar Mountain aquifer may be discharging into the surface water along Brown's Wash and thus entering the biological communities.

A potential further exposure pathway that does not now exist at the site is the installation of a well in a contaminated aquifer to create a stock pond and/or irrigate crops. A contaminated stock pond could affect livestock and wildlife that drank the water and aquatic organisms, including fish, that inhabited the pond. Humans and wildlife could also ingest contaminants by eating crops irrigated with contaminated ground water.

\section{ECOLOGICAL RECEPTORS}

This section briefly describes the terrestrial and aquatic resources at and near the site. This description is based on information collected during reconnaissance level surveys conducted since 1988. Surveys were conducted to support the environmental assessment, which addressed the impacts of cleaning up the surface contamination at the Green River site (DOE, 1988). Additional information was collected during a survey associated with a special study on plant biointrusion into the disposal cell (DOE, 1992; TAC, 1991) and during a field trip conducted in support of this ecological risk assessment (TAC, 1993c).

\subsubsection{Terrestrial resources}

\section{Plant communities}

The ground that was cleared during surface cleanup was revegetated with grasses. This revegetation effort largely failed, and the ground now harbors a dense growth of Russian thistle (TAC, 1991). An upland plant community that occurs in undisturbed land near the site is a desert shrub type dominated by species such as shadscale, saltbush, and rabbitbrush. The ground cover is composed of grass and herbs such as galleta grass, Indian rice grass, sand dropseed, scarlet globe mallow, and desert trumpet (DOE, 1988).

Brown's Wash runs along the northern border of the site, then flows into the Green River about $2000 \mathrm{ft}(600 \mathrm{~m})$ to the west. Riparian vegetation dominated by salt cedar has developed along the wash. Black greasewood and rabbitbrush were also common in some areas. A very dense growth of salt cedar occurs downgradient of the site, beginning at a west-side access road and ending at 
the Green River (Figure 7.1). Small clumps of cattails, sedges, and rushes were observed in this section of the wash (TAC, 1991; 1993c).

\section{Wildlife}

Little data are available regarding wildlife that occurs in the upland or riparian plant communities in the site area. Species recorded from the site include the turkey vulture, mallard, American kestrel, horned lark, Great Basin whiptail lizard, desert spiny lizard, and side-blotched lizard (DOE, 1988).

No threatened or endangered species are known to occur in the area of the site. Various age classes of the Colorado squawfish occur in the Green River near its confluence with Brown's Wash. The bald eagle occurs along the river during the winter, while the peregrine falcon has been reported from the riparian corridor along the river during migration (DOE, 1988).

\subsubsection{Aquatic resources}

Brown's Wash, an ephemeral stream, is a tributary of the Green River. A USGS gauging station operated along Brown's Wash in the area of the site from 1949 to 1968. The average maximum monthly flow in the wash was 69 cubic feet per second $\left(\mathrm{ft}^{3} / \mathrm{s}\right)$ (1950 liters per second $\left.[\mathrm{L} / \mathrm{s}]\right)$, and the average mean monthly flow was $36 \mathrm{ft}^{3} / \mathrm{s}(1020 \mathrm{~L} / \mathrm{s})$.

Brown's Wash north and upgradient of the Green River site is generally dry and the substrate is sandy. Downgradient of the site and the access road, the substrate is bedrock or silty soil; small pools of standing water frequently occur here. During a survey for aquatic resources, four small pools of water were observed in this area. In addition, moist soil was noted at the downstream end of culverts of the access road bridge and elsewhere in this section of the wash. Brown algae were growing in these pools, but no other aquatic organisms were observed (TAC, 1993c).

Samples collected from 1988 through 1992 from standing pools of water indicated that the $\mathrm{pH}$ was about 8 , with alkalinity ranging from 350 to $400 \mathrm{mg} / \mathrm{L}$ and TDS ranging from 966 to $21,500 \mathrm{mg} / \mathrm{L}$. Data from one 1989 sample taken from rapidly flowing water indicated that the $\mathrm{pH}$ was about 7.8 , the alkalinity was about $140 \mathrm{mg} / \mathrm{L}$, and the TDS was about $800 \mathrm{mg} / \mathrm{L}$.

\subsection{CONTAMINANTS OF POTENTIAL ECOLOGICAL CONCERN}

As presented in Section 3.5, analysis of surface water samples from the Green River shows that there is no statistically significant difference in water quality upstream or downstream of the river's confluence with Brown's Wash. This indicates that hazardous constituents associated with the Green River UMTRA Project site are probably not contaminating the water of the Green River. No sediment samples have been collected from the Green River, so the degree of 


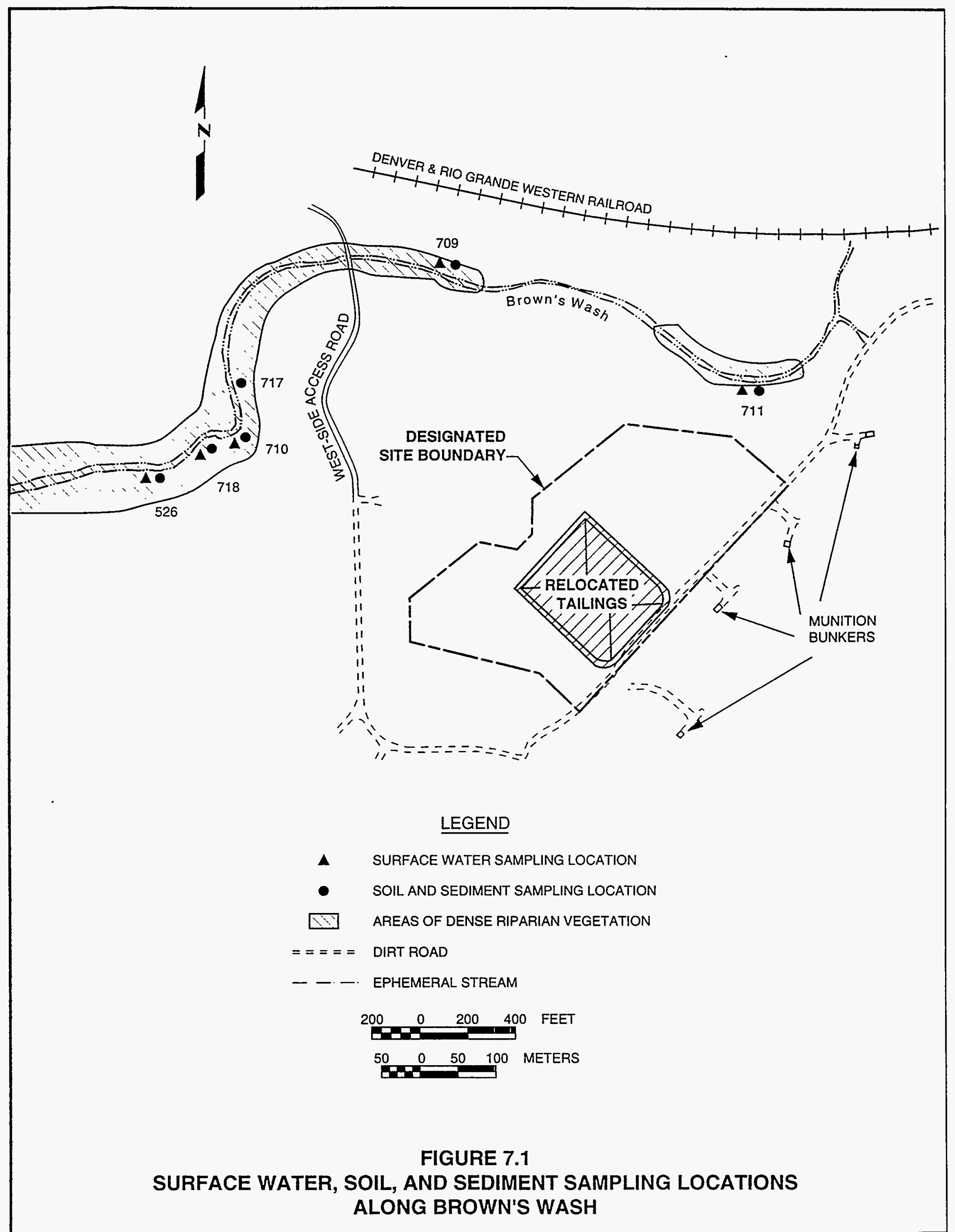


site-related contamination, if any, in these sediments is not known. The remainder of this ecological assessment focuses on Brown's Wash.

\subsubsection{Surface water and sediment sampling sites}

Surface water sampling has taken place at five locations along Brown's Wash (Figure 7.1) and two along the Green River. The Green River sampling sites are upriver and downriver of the confluence with Brown's Wash. The sampling locations along Brown's Wash are shown in Table 7.1. The downgradient locations were all within $400 \mathrm{ft}(120 \mathrm{~m})$ of each other and, for the purpose of this analysis, were combined to form the downgradient location. The downgradient sample locations are in areas of the wash with exposed bedrock where standing water is usually present; samples have been collected in 8 of 11 sampling rounds from 1988 to 1993 . Seven of these samples were from standing or slowly flowing water, and one was from rapidly flowing water resulting from a rain storm.

Table 7.1 Surface water sampling sites along Brown's Wash at the Green River, Utah, site

\begin{tabular}{ccccc}
\hline \multirow{2}{*}{$\begin{array}{c}\text { Sample } \\
\text { identification } \\
\text { number }\end{array}$} & Location & & \multicolumn{2}{c}{ Sampling rounds since 1987 } \\
\cline { 5 - 5 } \cline { 4 - 5 } & Years sampled & Water present & Water absent \\
\hline 711 & Upgradient & 1982 to present & 1 & 9 \\
709 & Crossgradient & 1982 to present & 4 & 6 \\
710 & Downgradient & 1982 to 1987 & NA & NA \\
718 & Downgradient & 1993 & 1 & $\mathrm{~b}$ \\
526 & Downgradient & 1982 to 1993 & 7 & 3 \\
\hline
\end{tabular}

asee Figure 7.1 for locations of sampling sites.

bonly one sample taken at this location.

The Brown's Wash upstream sampling location (711) has been sampled twice since 1982. These samples were taken during periods of runoff associated with rain storms. The wash's substrate is sandy, so after the runoff ceases the wash dries up. Therefore, this sampling location was dry during most of the surface water sampling rounds. The crossgradient sample location (709) also has a sandy substrate but has water more often than location 711 ; there was water at this location for 5 of 11 sampling rounds from 1988 into 1993.

Sampling location 711 is upstream from the Green River UMTRA Project site and is considered a background sampling location for the wash when water is flowing. However, location 711 cannot be considered a background location for samples taken from standing water, because no standing water has ever been observed there. Therefore, there are currently no background surface water 
quality data to compare to the surface water data collected at the crossgradient and downgradient sampling locations during periods of no or very low flows.

The results of this analysis (discussed below) suggest that contaminated ground water from the alluvial and/or Upper Cedar Mountain aquifer may be entering Brown's Wash in the area of the crossgradient and downgradient sampling locations. Background water quality data are not available for the alluvium but are available for the Upper Cedar Mountain aquifer.

Sediment samples were collected from six locations along Brown's Wash in 1993 (Figure 7.1). Sediment samples collected from sampling locations 526 , 709,710 , and 711 were dry, while samples from locations 717 and 718 were wet (TAC, 1993c). Sampling location 711 serves as a background location for samples collected in the sandy substrate of Brown's Wash. However, there are no background data for sediments that occur in areas of standing water in Brown's Wash.

\subsubsection{Source of sediment and surface water contamination}

The surface water sampling results for Brown's Wash for the last 10 years have shown that flowing water is only rarely present, while pools of standing or slowly flowing water are present much more often. These pools hold a greater potential to function as potential exposure points. For this reason, this ecological risk assessment will center on the water and sediment quality of these pools.

As indicated above, there are no surface water or alluvial ground water background water quality data to compare to detected constituent concentrations in standing water at the crossgradient and downgradient sampling sites or the Brown's Wash alluvial ground water. However, based on the chemical concentrations in surface water at these locations, it is likely that at least some of the surface water contamination is not naturally occurring but originates from the ground water at the Green River site. For example, sulfate, nitrate, and uranium showed much higher maximum concentrations in the standing surface water samples $(9090,2410$, and $1.89 \mathrm{mg} / \mathrm{L}$, respectively), the contaminated alluvial ground water (Table 3.2), and the contaminated Upper Cedar Mountain ground water (Table 3.3) when compared with the Upper Cedar Mountain aquifer background ground water levels (Table 3.3).

Potential sources of this contaminated surface water could be contaminated water that remains in the pools following a runoff event, contaminated soil and/or substrate, or contaminated ground water flowing into Brown's Wash. Although data are limited, it appears that flowing water in the wash from storm events is not the source of this contamination. Flowing water sampled in September 1989 downgradient of the site had low levels of uranium, nitrate, and sulfate relative to downgradient standing surface water or contaminated ground water (see Table 7.3). In addition, weather data from Green River indicate that little if any precipitation fell previous to most surface water 
sampling dates. For example, surface water was sampled at the downgradient site on January 10,1990, even though there had been zero precipitation in the previous 30 days. Standing water was sampled in the downgradient location on September 21,1993 , even though there had only been 0.02 inch $(0.05 \mathrm{~cm})$ of rain on September 18 and 0.08 inch $(0.2 \mathrm{~cm})$ of rain on September 6 . These data indicate that the water at the downgradient locations during periods of no flow does not originate from surface flow.

Waterborne and windblown contaminated material has entered Brown's Wash in the past. During remedial action, tailings and windblown contamination were cleaned up on both sides of the wash. However, the wash itself was found to be clean and no remediation was required (DOE, 1991). Therefore, it is unlikely that the contaminated surface water and sediment in Brown's Wash originates from surface contamination.

\subsubsection{Contaminants of potential concern}

The contaminated surface water in Brown's Wash may be the result of contaminated ground water from the alluvium and/or Upper Cedar Mountain aquifers discharging to the surface. No background water quality data exist for the surface water or the alluvial ground water, so constituents that exceeded background concentrations in the Upper Cedar Mountain aquifer were used to determine the contaminants of potential concern addressed in this ecological risk assessment. Except for cadmium, this approach considers all constituents that have relatively high values in the surface and alluvial ground water. Cadmium concentrations in the contaminated Upper Cedar Mountain aquifer did not exceed background levels. However, cadmium concentrations in the alluvium did exceed the Upper Cedar Mountain background levels and were also relatively high in the sediments downgradient of the site. For these reasons, cadmium was included in the list of contaminants of potential concern considered in this assessment.

A total of 20 constituents were used to determine the contaminants of potential concern (Table 7.2). Concentrations of these constituents were compared with water quality criteria or various guidelines to determine the final list of contaminants of potential concern. Where available, state of Utah criteria for the protection of aquatic life (UDEO, 1992) were also used to screen contaminants of potential concern. When state criteria were not available, Federal Water Quality Criteria (FWOC) were used (EPA, 1986; 1991). If no federal criteria were available, other published guidelines were used (CDPHE, 1991).

Aquatic life water quality criteria or guidelines are not available for 8 of the 20 constituents (Table 7.2). There is little information regarding the potential ecological effects of elevated concentrations of seven of these constituents, and state, federal, or other aquatic life criteria or guidelines are not available. For these reasons, the potential ecological risks associated with these constituents could not be assessed. Some limited information is available to evaluate the 


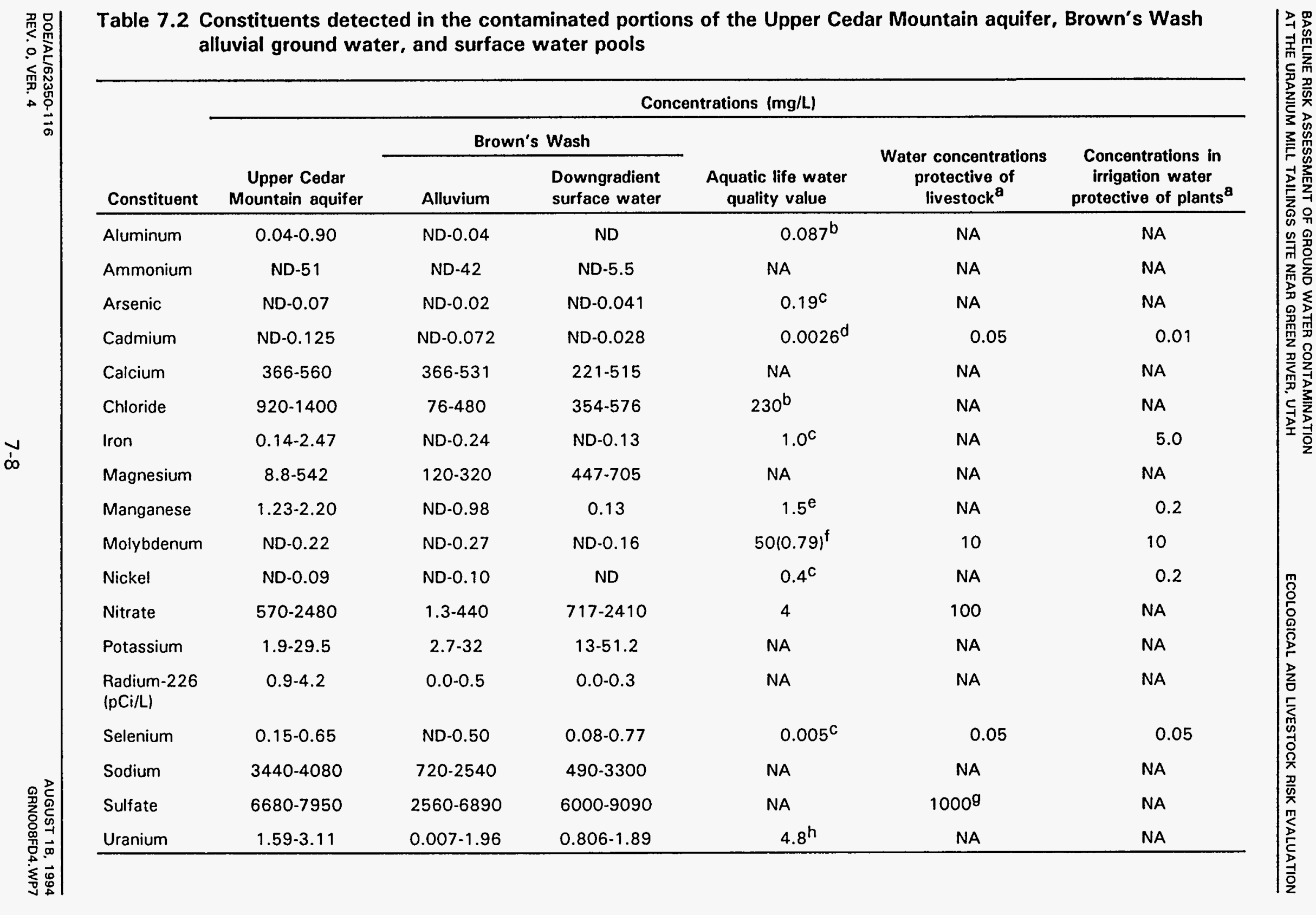


Table 7.2 Constituents detected in the contaminated portions of the Upper Cedar Mountain aquifer, Brown's Wash alluvial ground water, and surface water pools (Concluded)

\begin{tabular}{|c|c|c|c|c|c|c|}
\hline \multirow[b]{3}{*}{ Constituent } & \multicolumn{6}{|c|}{ Concentrations (mg/L) } \\
\hline & \multirow[b]{2}{*}{$\begin{array}{l}\text { Upper Cedar } \\
\text { Mountain aquifer }\end{array}$} & \multicolumn{2}{|c|}{ Brown's Wash } & \multirow[b]{2}{*}{$\begin{array}{c}\text { Aquatic life water } \\
\text { quality value }\end{array}$} & \multirow{2}{*}{$\begin{array}{l}\text { Water concentrations } \\
\text { protective of } \\
\text { livestock }^{\mathbf{a}}\end{array}$} & \multirow{2}{*}{$\begin{array}{l}\text { Concentrations in } \\
\text { irrigation water } \\
\text { protective of plants }\end{array}$} \\
\hline & & Alluvium & $\begin{array}{l}\text { Downgradient } \\
\text { surface water }\end{array}$ & & & \\
\hline Vanadium & ND-0.38 & ND-0.24 & ND-0.09 & NA & NA & NA \\
\hline Zinc & ND-0.068 & ND-0.036 & ND-0.016 & $0.26^{d}$ & 25 & 2.0 \\
\hline
\end{tabular}

aFrom EPA (1972) unless specified otherwise. Irrigation water values shown are for water used continuously on all soils.

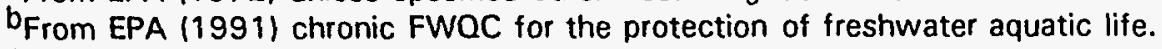

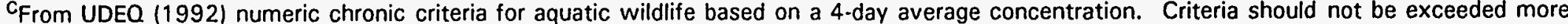

than once every 3 years on average.

dWater hardness-related state chronic criteria (UDEQ, 1992). Criteria calculated using average Brown's Wash alluvial aquifer hardness of $286 \mathrm{mg} / \mathrm{L} \mathrm{CaCO}$ from wells 702, 704, 705, 708, and 808

e From EPA (1986). Value presented is the lower end of the range of tolerance values for freshwater aquatic life.

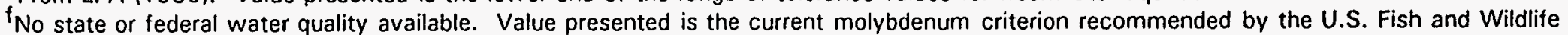

Service for the protection of aquatic organisms with one exception, newly fertilized rainbow trout eggs, which are sensitive to molybdenum concentrations above $0.79 \mathrm{mg} / \mathrm{L}$.

gFrom National Research Council, 1971.

$h_{\text {From water hardness-related chronic criteria, state of Colorado (CDPHE, 1991). Criteria calculated using hardness of } 286 \mathrm{mg} / \mathrm{L} \mathrm{CaCO}}$.

NA - Not available.

ND - Not detected. 
potential effects of sulfate on livestock; therefore, this constituent is included in this assessment. Maximum concentrations of 5 of the remaining 12 constituents did not exceed the Utah criteria, FWOC, or the other guidelines (Table 7.2) and, except for uranium, these constituents will not be considered further in this assessment. Uranium was analyzed in this assessment because elevated concentrations were measured in the sediments of Brown's Wash. The remaining seven constituents exceeded the criteria; of these, aluminum was eliminated from further consideration because it was not detected in the surface water, did not exceed the criteria in the alluvium, and was just barely above the criteria in the Upper Cedar Mountain aquifer. Contaminants of potential concern, then, are cadmium, chloride, iron, manganese, nitrate, selenium, sulfate, and uranium (Table 7.3).

\subsection{POTENTIAL IMPACTS TO TERRESTRIAL AND AQUATIC RESOURCES}

The potential pathways for contaminants to reach aquatic and terrestrial resources at the Green River site are via the contaminated ground water, surface water, and sediments along Brown's Wash. The discussion of potential contaminants first addresses the possibility of ecological risk arising from the surface water and sediments along the wash and the discharge of contaminated ground water into the wash (termed surface contamination along Brown's Wash). Possible aquatic and terrestrial impacts of seven of the eight contaminants of potential concern are addressed. Sulfate toxicity is addressed only in terms of potential impacts to livestock. Finally, the potential impacts of contaminated ground water on the terrestrial environment via root uptake of contaminants are discussed.

At this time, the extent of contamination in the surface water, sediments, and biota at the Green River site is not known. For the purposes of this ecological risk assessment, it is assumed that contaminated ground water is available only in the area of the site and that contaminated surface water and sediments occur in a 200- to $400-\mathrm{ft}(60-$ to $120-\mathrm{m})$ section of Brown's Wash. Surface water quality data from the Green River suggest that the river is not affected by siterelated contamination. The contamination in Brown's Wash could cover a larger area than assumed.

\subsubsection{Ecological risk of surface contamination}

This section discusses the potential effects of cadmium, chloride, iron, manganese, nitrate, selenium, and uranium on aquatic and terrestrial ecological receptors. Potential effects of sulfate are discussed for livestock.

\section{Cadmium}

Cadmium was detected in downgradient and crossgradient standing surface water locations and in the alluvial and Upper Cedar Mountain ground water (Table 7.3). Cadmium concentrations exceed state of Utah criteria for protection of aquatic life of $0.0026 \mathrm{mg} / \mathrm{L}$ (Table 7.2 ). One reason cadmium is 


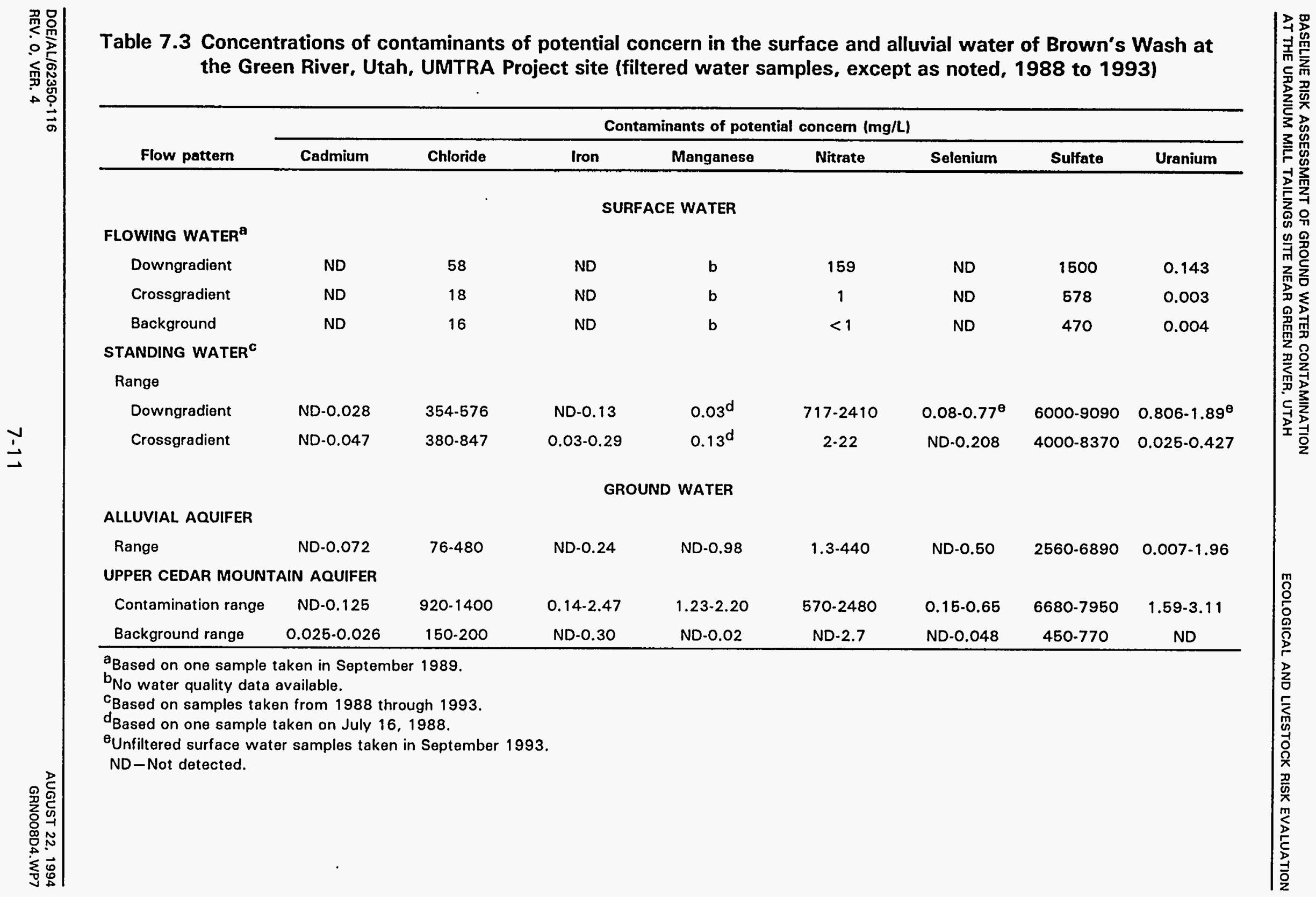


toxic at such low levels is its tendency to bioaccumulate; bioconcentration factors of 33 to 7440 have been calculated for freshwater insects, fish, and algae (Eisler, 1985a). However, cadmium has been encountered only in alluvial ground water in one well during one sampling round and has not been detected in surface water since January 1990. Therefore, cadmium may not be entering the environment from the contaminated ground water in the alluvial aquifer.

Cadmium levels observed in the sediments of Brown's Wash in 1993 are shown in Table 7.4. Studies have shown that adverse effects on biota were observed at cadmium levels in sediments ranging from 0.6 to $5 \mathrm{mg} / \mathrm{kg}$. Severe effects have been reported at 9 to $10 \mathrm{mg} / \mathrm{kg}$ (Long and Morgan, 1990; Persaud et al., 1990). The cadmium levels at all locations except 718 are below the lowest observed effect concentrations of $0.6 \mathrm{mg} / \mathrm{kg}$ (Table 7.4). The cadmium concentration at location 718 is above the lowest observed effect concentration but below the lowest concentration reported to cause severe toxic effects $(9 \mathrm{mg} / \mathrm{kg}$ ).

Table 7.4 Concentrations of contaminants of potential concern in sediment samples collected along Brown's Wash, September 1993, Green River, Utah, site

\begin{tabular}{|c|c|c|c|c|c|}
\hline \multirow[b]{3}{*}{ Constituent } & \multicolumn{5}{|c|}{ Sample location $^{a}$} \\
\hline & \multicolumn{3}{|c|}{ Downgradient $^{b}$} & \multirow{2}{*}{$\frac{\text { Crossgradient }}{709 \text { (dry) }}$} & \multirow{2}{*}{$\begin{array}{l}\text { Upgradient } \\
711 \text { (dry) } \\
\end{array}$} \\
\hline & 526 (dry) & 717 (wet) & 718 (wet) & & \\
\hline Cadmium & 0.3 & 0.3 & 3.5 & 0.3 & 0.1 \\
\hline Selenium & 0.8 & 1.3 & 3.1 & ND & ND \\
\hline Uranium & 2.0 & 10.5 & 27.7 & ND & ND \\
\hline
\end{tabular}

a See Figure 7.1 for location of sampling sites.

${ }^{b}$ All concentrations in $\mathrm{mg} / \mathrm{kg}$ dry weight.

ND-Not detected.

Cadmium has also been shown to bioconcentrate in plants. For example, lettuce grown on soils with $2.5 \mathrm{mg} / \mathrm{kg}$ cadmium had concentrations of $11.5 \mathrm{mg} / \mathrm{kg}$ cadmium. This suggests that vegetation in the contaminated portions of Brown's Wash may also be bioconcentrating cadmium. Cadmium can biomagnify up the food chain and has a tendency to concentrate in certain animals' internal organs. For example, mallard ducklings fed a diet containing $20 \mathrm{mg} / \mathrm{kg}$ cadmium for 12 weeks accumulated $42 \mathrm{mg} / \mathrm{kg}$ cadmium in their livers (Eisler, 1985a).

\section{Chloride}

Chloride levels are elevated above the criteria for protection of aquatic life $(230 \mathrm{mg} / \mathrm{L}$ ) in the downgradient (maximum of $576 \mathrm{mg} / \mathrm{L}$ ) and crossgradient 
(maximum of $847 \mathrm{mg} / \mathrm{L}$ ) surface water locations (Tables 7.2 and 7.3). These data are for samples collected from standing water. Chloride concentrations were much less from the one flowing surface water sampling round (maximum of $58 \mathrm{mg} / \mathrm{L}$ ). The elevated concentrations are similar to the highest levels detected in the contaminated Brown's Wash alluvial ground water. The maximum chloride concentration of $847 \mathrm{mg} / \mathrm{L}$ was crossgradient of the site; this is just below the acute FWOC of $860 \mathrm{mg} / \mathrm{L}$, the maximum recommended concentration for fresh water (EPA, 1991). Data regarding the nature and severity of effects of elevated chloride on aquatic and terrestrial ecological systems are not available.

Iron

Maximum concentrations of iron in the surface water $(0.29 \mathrm{mg} / \mathrm{L})$ and alluvial aquifer $(0.24 \mathrm{mg} / \mathrm{L})$ are below the value considered protective of aquatic life $(1.0 \mathrm{mg} / \mathrm{L})$. The maximum concentration in the Upper Cedar Mountain aquifer $(2.4 \mathrm{mg} / \mathrm{L})$ is well above the aquatic life criteria. It is believed that if the Upper Cedar Mountain aquifer is the source of the water discharged into Brown's Wash, iron concentrations are quickly reduced once the water is oxygenated on the surface. Therefore, iron does not appear to pose an ecological risk at the Green River site.

\section{Manganese}

Manganese was sampled only once since 1988 in the surface water of Brown's Wash. The highest concentrations occurred at the crossgradient locations (Table 7.3). The maximum concentration in the Brown's Wash alluvium was $0.98 \mathrm{mg} / \mathrm{L}$, and in Upper Cedar Mountain aquifer, $2.2 \mathrm{mg} / \mathrm{L}$. Data for manganese toxicity in freshwater organisms indicate that the tolerance values range from 1.5 to $1000 \mathrm{mg} / \mathrm{L}$ in water (EPA, 1986). Therefore, the relatively low concentrations of manganese in the alluvial and surface water of Brown's Wash are not likely to result in toxic effects to aquatic organisms that may inhabit the surface water in Brown's Wash downgradient of the site. However, the concentrations in the Upper Cedar Mountain aquifer are likely toxic to some aquatic organisms.

There are no data regarding the concentrations of manganese in the soil or plants along Brown's Wash. Studies of the uptake of manganese by plants growing on copper mine spoil in Arizona showed that plants accumulate manganese at levels up to 17 times greater than levels in the spoil material (Hobbs and Streit, 1986). However, even though bioaccumulation of manganese may be taking place in the plants along Brown's Wash, it is assumed that there is no ecological risk associated from the levels of manganese along Brown's Wash. This is because the concentrations in the surface water are relatively low and the concentrations in the soils and sediments would also likely be relatively low. 


\section{Nitrate}

Nitrate levels are highly elevated in downgradient standing surface water, with a maximum concentration of $2410 \mathrm{mg} / \mathrm{L}$ (Table 7.3). This is more than 100 times higher than the maximum crossgradient levels, more than 5 times higher than the maximum nitrate contamination in the alluvial aquifer, and about the same as the maximum value from the Upper Cedar Mountain aquifer. The maximum surface water concentration is also over 600 times greater than the state of Utah criteria for the protection of aquatic life $(4 \mathrm{mg} / \mathrm{L})$.

Studies regarding the effects of nitrate on fish have shown that 96-hour and 7 -day $L C_{50}$ values (levels at which 50 percent of fish died) ranged from 1000 to $2000 \mathrm{mg} / \mathrm{L}$, while the most sensitive freshwater fish species could survive in waters with only $90 \mathrm{mg} / \mathrm{L}$ nitrate without significant effects on growth or feeding behavior (Knepp and Arkin, 1973; Trama, 1954; and Westin, 1974 as cited in EPA, 1986). Based on this information, it is assumed that the elevated levels of nitrate in downgradient surface water along Brown's Wash would have a toxic effect on most aquatic organisms if they occur in these waters. These levels of nitrate, along with the ephemeral nature of the pools and the presence of other contaminants discussed below, may explain why no aquatic animals and very few aquatic plant species were encountered in the shallow pools of water downgradient of the site.

\section{Selenium}

Selenium concentrations were detected in the crossgradient and downgradient standing surface water locations (Table 7.3). The maximum concentrations at the locations are 42 and 152 times greater than the state of Utah criterion $(0.005 \mathrm{mg} / \mathrm{L})$, which is considered protective of aquatic life via chronic exposure (UDEO, 1992). Current FWOC stipulate that selenium should not exceed $0.005 \mathrm{mg} / \mathrm{L}$ (chronic) and $0.02 \mathrm{mg} / \mathrm{L}$ (acute) (EPA, 1991). It has been demonstrated that concentrations of 0.06 to $0.60 \mathrm{mg} / \mathrm{L}$ selenium are fatal to various sensitive aquatic organisms (Eisler, 1985b).

Selenium has been detected in the downgradient surface water since 1987, with the highest levels being recorded in $1993(0.77 \mathrm{mg} / \mathrm{L})$. The levels of selenium in these surface water bodies could be detrimental to the survival of aquatic organisms that may inhabit these waters. Prior to 1993, no surveys for aquatic life were conducted in Brown's Wash. No aquatic life, except brown algae, was observed in the pools during the reconnaissance survey in 1993 (TAC, 1993c). This could be due to the ephemeral nature of the pools and/or the high levels of selenium and other toxic constituents. Selenium concentrations in the brown algae were not measured; other studies have shown that algae growing in water containing $0.3 \mathrm{mg} / \mathrm{L}$ of selenium had selenium levels greater than $60 \mathrm{mg} / \mathrm{kg}$ (Ohlendorf, 1989).

Selenium was not detected in the sediments at the upgradient and crossgradient sample sites or at downgradient location 710 . It was detected in 
concentrations ranging from 0.8 to $3.1 \mathrm{mg} / \mathrm{kg}$ in the sediments at the other three downgradient locations (Table 7.4). Lemly and Smith (1987) indicate that levels of selenium in sediments should be less then $4 \mathrm{mg} / \mathrm{kg}$ to be protective of biological systems, which is greater than the levels detected in this study. However, the relatively high levels of selenium in the surface water could have localized negative effects on terrestrial plants and wildlife. For example, aquatic and terrestrial vascular plants in a selenium-contaminated wildlife refuge in California contained, on average, 27 and $30 \mathrm{mg} / \mathrm{kg}$ of selenium; the water entering the refuge contained $0.3 \mathrm{mg} / \mathrm{L}$ selenium, which is less than the maximum contamination in the contaminated surface water along Brown's Wash $(0.77 \mathrm{mg} / \mathrm{L})$. Selenium tends to bioconcentrate; bioconcentration factors for plants and detritus are generally less than 1000 and for animals are generally above 1000 (Ohlendorf, 1989). Data regarding selenium concentrations in aquatic and wetlands plants were not collected during this study, so the degree, if any, of selenium concentration in biological communities in the Brown's Wash area is not known at this time.

\section{Uranium}

No state of Utah or federal aquatic criteria for uranium are available. Toxicity testing of uranium using Daphnia magna has shown that acute toxicity can occur from uranium concentrations as low as $5.34 \mathrm{mg} / \mathrm{L}$; chronic effects were noted at concentrations as low as $0.5 \mathrm{mg} / \mathrm{L}$ (Poston et al., 1984). The toxic effects of uranium are reduced as alkalinity and hardness increase. Using a regression equation provided by Poston et al. (1984) and an average alkalinity of $286 \mathrm{mg} / \mathrm{L} \mathrm{CaCO}_{3}$ in the Brown's Wash alluvium (from wells 702, 704, 705, 708 , and 808 ), the concentration of uranium predicted to cause acute toxicity is $63 \mathrm{mg} / \mathrm{L}$. This would indicate that the concentrations of uranium in the downgradient surface water location and contaminated ground water would not result in acute toxicity. The estimate of $0.5 \mathrm{mg} / \mathrm{L}$ uranium as the lowest concentration for which chronic effects were observed was determined using water with relatively low alkalinity. Poston et al. (1984) did not provide a regression equation for chronic effects, and the state of Utah does not have a criterion for uranium that is protective of aquatic life (UDEQ, 1992). Therefore, a regression equation for chronic effects of uranium developed by the state of Colorado was used (CDPHE, 1991). Using an average alkalinity of $286 \mathrm{mg} / \mathrm{L}$ $\mathrm{CaCO}_{3}$, the estimated concentration of uranium that could result in chronic effects is $4.8 \mathrm{mg} / \mathrm{L}$. Based on this, it does not appear that uranium concentrations in the contaminated ground water or surface water will result in chronic adverse effects.

Sediment samples collected from Brown's Wash in 1993 were analyzed for uranium. It was not detected upgradient (location 711) or crossgradient (location 709) of the site but was detected in downgradient locations (Table 7.4). Little information is available regarding potential adverse effects of elevated levels of uranium in sediment on terrestrial and aquatic ecosystems. It is clear that plant roots will take up and transport uranium to various parts of the plant (Dreesen and Marple, 1979; Dreesen et al., 1982; Ibrahim and 
Whicker, 1988; Lapham et al., 1989). Plants do not appear to bioconcentrate uranium to a high degree; the plant-to-soil uptake factor ranged from 0.04 to 0.81 at a site in Wyoming (Ibrahim and Whicker, 1988). In New Mexico, plantto-soil uptake factors for uranium varied from 0.05 to 0.27 (Lapham et al., 1989). Studies have also shown that cattle grazing on vegetation with elevated levels of uranium and other radionuclides above background levels accumulate these constituents, with higher concentrations in the liver, kidney, and bone than in the muscle (Lapham et al., 1989). Thus, it appears that uranium may be transported up the food chain to some degree. The ecological risk associated with uranium concentrations in the sediments of Brown's Wash cannot be determined at this time, because the extent and degree of uranium contamination in the sediments, soil, and vegetation along the wash are not known.

A hypothetical pathway for contaminants to enter the aquatic and terrestrial ecosystem would be the construction of a stock pond using contaminated ground water from the Brown's Wash alluvial aquifer or the Upper Cedar Mountain aquifer. The contaminants of potential concern for aquatic and terrestrial organisms would be the same as those considered for the contaminated surface water along Brown's Wash: chloride, iron, manganese, nitrate, selenium, sulfate, and uranium. Therefore, the same types of potential adverse effects would be expected to occur in aquatic and terrestrial organisms that would drink water from a stock pond. There would be a potential for cadmium, manganese, nitrate, selenium, and possibly uranium to result in toxic effects to the terrestrial ecosystem. As observed in the contaminated surface water along Brown's Wash, it is unlikely that aquatic life could exist in such a stock pond.

Another hypothetical pathway would be the use of contaminated water from the alluvial and Upper Cedar Mountain aquifers for irrigation. The maximum concentrations of constituents measured in the alluvial and Upper Cedar Mountain ground water were compared to criteria protective of plants (EPA, 1972) (Table 7.2). Such criteria exist for 7 of the 20 constituents listed in Table 7.2. Cadmium, manganese, and selenium are the only constituents for which concentrations exceed these criteria. Based on this, use of the contaminated alluvial ground water as a source of continuous irrigation water may damage crops.

\subsubsection{Ecological risk associated with plant root transport of contaminants}

A potential pathway for hazardous constituents to enter the terrestrial environment is via plants rooting in the contaminated Brown's Wash alluvium or shallow areas of the Upper Cedar Mountain aquifer. Plants growing along Brown's Wash are probably rooted in this shallow ground water and may be transporting contaminants of potential concern into the aboveground portions of the plants. This is particularly true for riparian and pseudo-riparian plant species, such as salt cedar and black greasewood, that are common along the wash. These species require more water than is available from precipitation, 
and their roots can easily reach the shallow ground water in the Brown's Wash alluvium.

Contaminants taken up by plants have the potential to be toxic to the plants themselves (phytotoxicity) and/or move up the food chain when herbivores feed on the plants. Concentrations of the contaminants of potential concern were not measured in the riparian plants or the soil in which they are rooted.

To determine whether the contaminants of potential concern could be phytotoxic, the maximum concentrations of these constituents in the contaminated ground water were used to estimate concentrations in the soil. Published soil-to-plant biological concentration ratios were used to estimate concentrations that may occur in plants. These concentrations were then compared with published phytotoxic data for these constituents. It is recognized that plant uptake of the contaminants varies widely among plant species and that other factors (such as soil characteristics and water chemistry) also can lead to wide variations in plant uptake of a specific constituent. Additionally, plants could take contaminants directly out of the water. This analysis was performed to provide an order-of-magnitude estimate of the potential for the contaminants to be phytotoxic.

The results of the phytotoxicity analysis indicated that estimated concentrations of cadmium are within the same order of magnitude as the published toxic levels (Table 7.5). The estimated concentrations of other constituents for which phytotoxic data are available are two to three orders of magnitude less than toxic levels. Based on this, cadmium may be phytotoxic to riparian vegetation growing along Brown's Wash. Water sampling of the contaminated section of the Brown's Wash alluvium has not taken place since 1988, so the current concentrations of contaminants of potential concern are not known. If current concentrations are similar to 1988 levels, the potential for phytotoxicity still exists.

\subsection{POTENTIAL IMPACTS TO LIVESTOCK}

As indicated earlier, it is believed that contaminated ground water from the Brown's Wash alluvium and/or the Upper Cedar Mountain aquifer is discharging into Brown's Wash and creating pools of contaminated water. The land in which this area of Brown's Wash occurs could be grazed by livestock. In addition, livestock could consume vegetation growing near these pools or plants that have rooted in the contaminated Brown's Wash alluvium or Upper Cedar Mountain aquifer. However, without data regarding the levels of potential contaminants in the vegetation, it is difficult to evaluate this exposure pathway.

To evaluate the potential impact to cattle drinking the contaminated surface water along Brown's Wash, the observed concentrations for the contaminants of potential concern were compared to drinking water guidelines considered protective of livestock (Table 7.2). Guidelines are available for six of the contaminants of potential concern; of these, cadmium, nitrate, selenium, and 


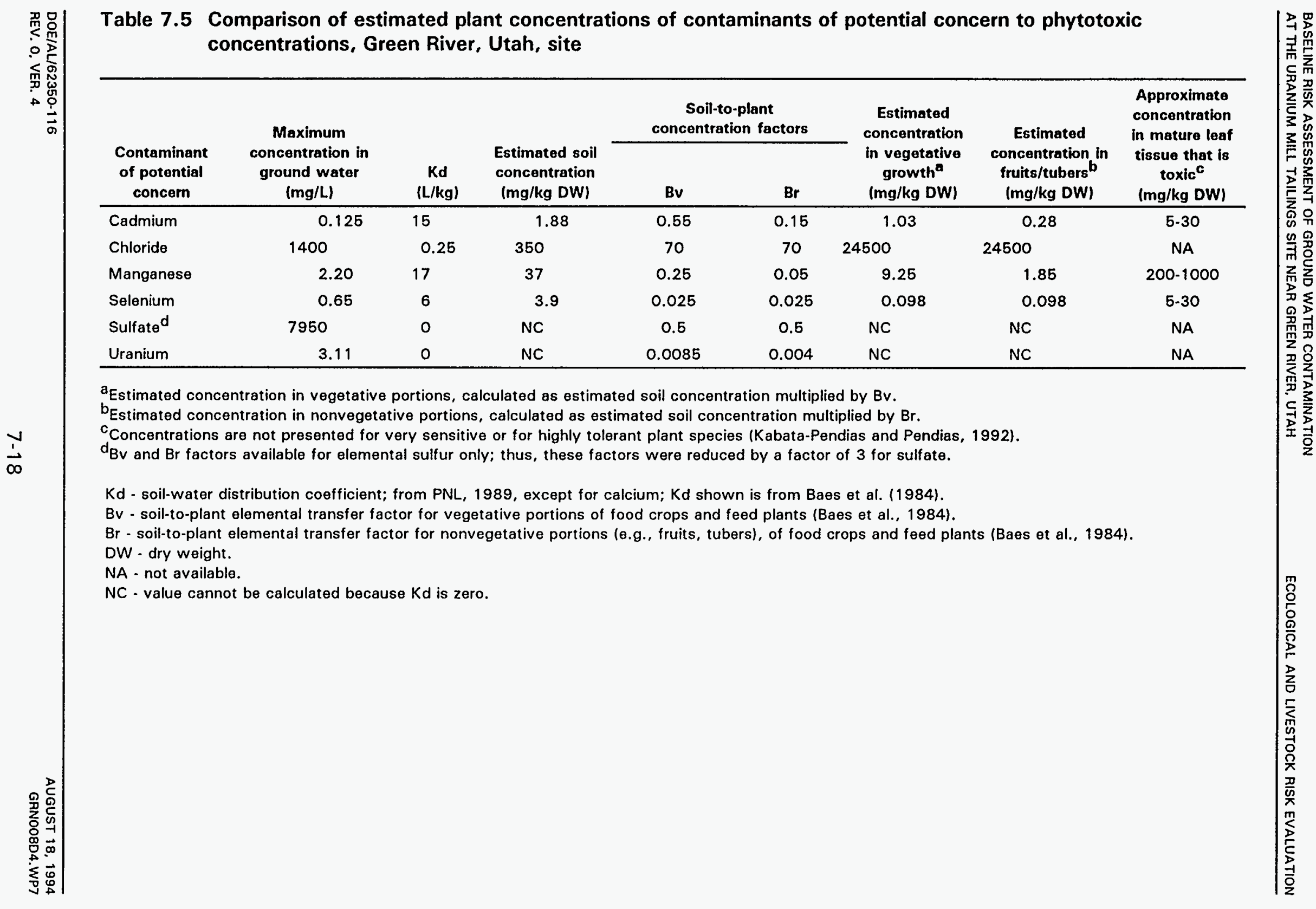


sulfate concentrations exceeded the guidelines. Cadmium concentrations measured to date in surface water along Brown's Wash have not exceeded the level considered protective of livestock. The maximum concentrations in the alluvial and Upper Cedar Mountain aquifers exceed the guidelines. Although cows have an efficient mechanism to prevent cadmium from entering milk, tests on other animals have shown that excessive cadmium will accumulate in the liver and kidney (EPA, 1972). Therefore, the concentration of cadmium in the contaminated ground water has the potential to be toxic to livestock.

Nitrate concentrations in the contaminated surface water far exceed the concentration that is protective of livestock. If this surface water were a major source of livestock drinking water, it would ultimately cause death due to methemoglobinemia (Deeb and Sloan, 1975; NAS, 1972).

Selenium is another constituent that exceeds the livestock watering criteria. Chronic selenosis can occur in cattle that drink water with 0.5 to $2.0 \mathrm{mg} / \mathrm{L}$ selenium and results in skin lesions, loss of hair, anemia, and other symptoms (Eisler, 1985b). The concentrations of selenium in the contaminated surface water could cause selenosis in livestock that drink this water.

Sulfate concentrations are high in the contaminated surface water, and consumption could result in diarrhea (Church, 1984).

Very little sign of livestock activity was observed along Brown's Wash during brief reconnaissance surveys in 1991 and 1993; a few horse tracks were noted in 1993 (TAC, 1991; 1993c). Livestock are typically attracted to riparian areas, especially in the summer; if they had been in the area, signs of their presence would have been abundant, as has been observed in riparian areas at other UMTRA Project sites in the arid west (DOE, 1994c;1994d). Therefore, it does not appear that livestock currently graze in the area of contamination along Brown's Wash. However, grazing animals could be introduced to the area in the future, and the risk of exposure of livestock to the contaminated surface water would increase.

It is possible that a well could be developed in the future in the contaminated alluvial or Upper Cedar Mountain aquifers to fill a stock pond. The water quality of a stock pond filled with contaminated ground water would be similar to the existing water quality in Brown's Wash. Livestock would probably die from drinking water from such a stock pond.

\subsection{LIMITATIONS OF THE ECOLOGICAL RISK ASSESSMENT}

The qualitative evaluation of potential ecological risks presented here is a screening level assessment of the risks associated with potential exposure of plants and animals to contaminated ground water, surface water, and sediments at the Green River site. Sources of uncertainty in any ecological assessment arise from the monitoring data, exposure assessments, toxicological information, and inherent complexity within the ecosystem. In addition, methods of 
predicting nonchemical stresses (e.g., drought), biotic interactions, behavior patterns, biological variability (i.e., differences in physical conditions, nutrient availability), and resiliency and recovery capacities are often unavailable. In general, limitations for the Green River ecological risk assessment include the following:

- Only a small amount of ecological data were collected during this screening.

- Little is known about site-specific intake rates for wildlife or amounts of contaminants taken up by plants. General literature values were used in many cases.

- Only limited ecotoxicological reference data are available.

- Considerable uncertainty is associated with the toxicity of combined contaminants.

7.7 SUMMARY

The primary risk to ecological receptors and livestock is associated with the levels of nitrate, selenium, and sulfate in the surface water and ground water. In addition, levels of cadmium, manganese, and uranium pose a potential risk to the aquatic and/or terrestrial environment.

Cadmium has not been detected in the surface water of Brown's Wash since 1990 and has not been measured in alluvial ground water since 1988. Ground water concentrations exceeded the levels considered to be protective of livestock, and an analysis of potential plant root uptake of this constituent from contaminated ground water indicated it may be toxic to plants.

Nitrate concentrations are high in the contaminated Brown's Wash surface water and contaminated ground water. This nitrate contamination could result in toxic effects to aquatic organisms that may live in these waters and terrestrial organisms that drink this water.

Selenium concentrations exceed the standards and guidelines in both the surface water and contaminated ground water. Concentrations of this constituent in the surface water could have chronic or acute effects on aquatic organisms. It is likely that selenium is being transported to the terrestrial environment from the contaminated surface water or from plant root uptake from the shallow alluvial aquifer.

Uranium concentrations are high in the surface water and ground water. However, due to high alkalinity, the concentrations of uranium in the water are not likely to result in acute or chronic toxicity to aquatic life. Uranium is probably entering the terrestrial environment through plants, but the degree of this uptake and the potential risk are not known. 
Sediment samples from Brown's Wash had high concentrations of cadmium, selenium, and uranium. The cadmium concentrations have the potential to adversely affect the terrestrial environment, principally because of this constituent's tendency to bioconcentrate. Selenium sediment concentrations were lower then the recommended minimum level for sediments but, given this contaminant's ability to bioconcentrate, it is believed that it has the potential to have a negative impact on the terrestrial environment. It is not known if the elevated uranium levels in the sediments of Brown's Wash would affect the aquatic or terrestrial environments.

This risk assessment determined that elevated concentrations of cadmium, nitrate, selenium, and sulfate would be harmful to livestock that may drink contaminated water. However, it did not appear that livestock are grazing in the area of the contaminated surface water at this time.

Insufficient water and sediment quality criteria were available to thoroughly evaluate the impacts of surface water, sediments, and contaminated ground water on ecological receptors. In addition, the areal extent of the contamination is not known. As with any qualitative ecological assessment, the uncertainties inherent in this assessment could be reduced through additional characterization and evaluation. 


\subsection{INTERPRETATION AND RECOMMENDATIONS}

\subsection{RISK SUMMARY}

The UMTRA Project is required by the UMTRCA to protect public health and the environment from radiological and nonradiological hazards associated with the uranium mill sites. This baseline risk assessment was conducted for the Green River site to evaluate the presence of these hazards. Because contaminated ground water is currently not used by area residents, human health is not at risk. However, health risks could be associated with potential future use of contaminated ground water from the Upper Cedar Mountain aquifer and Brown's Wash alluvium.

The primary risks associated with ground water contamination in the Upper Cedar Mountain aquifer and alluvium result from the ingestion of nitrate and sulfate by humans and animals. Drinking ground water from the plume would result in nitrate intakes in the potentially lethal range for infants following even short-term exposures. Sulfate levels are associated with severe diarrhea. These nitrate and sulfate levels are also unacceptable for domestic animals and wildlife.

The risks associated with ground water used for drinking are also unacceptable for sodium, manganese, and selenium. This water is potentially in the mild toxicity range for children following chronic ingestion exposures to these metals. For the Brown's Wash alluvium ground water, the lifetime excess cancer risk from ingesting radioactive uranium and its decay products is at an unacceptable level of 9 in 10,000, compared to the maximum excess cancer risk of 1 in 10,000 used by the EPA for Superfund sites. For the Upper Cedar Mountain aquifer, lifetime excess cancer risks associated with uranium (7 in 10,000), uranium decay products (2 in 10,000), and arsenic (5 in 10,000) are also at unacceptable levels.

In addition to human health risks, the contaminated ground water at the site would not be suitable for watering livestock or crops. Because of high nitrate and sulfate levels, livestock would not survive chronic ingestion of this ground water as a sole source of water. The concentrations of cadmium, manganese, nitrate, selenium, and uranium measured in the surface water of Brown's Wash would be toxic to many aquatic organisms and/or the terrestrial environment. These contaminants would also be harmful to livestock that drank contaminated water.

\subsection{LIMITATIONS OF THIS RISK ASSESSMENT}

The following limitations to this evaluation of health and environmental risks should be noted: 
- In general, the results presented in this document are based on filtered (0.45-micrometer) water samples. The effect of filtration differs for different elements. Filtered samples can have equal or lower concentrations than unfiltered samples for some constituents. Constituents in suspension may be lost with filtration but can still produce toxic effects if ingested and broken down in the acidic environment of the stomach.

- The toxicity of any contaminant varies from individual to individual. By using probability distributions for potential exposure and presenting ranges of exposures that can produce toxic effects, this assessment tries to emphasize that variability. However, it is not possible to account for all sources of variability and still present useful and meaningful analyses. Cases in which specific subpopulations of individuals are known to be more sensitive to toxic effects of given constituents have been noted. Using ranges for expected toxic effects and distributions for expected exposures provides the reader with a better understanding of the likelihood that toxicity will occur.

- To assess toxicity, standardized reference values developed by regulatory agencies and literature values are used to determine plant uptake, tissue concentrations in livestock, and toxic effects in humans. These reference values themselves have limitations, including the following:

- Toxicity, uptake, or bioconcentration data are not available for all constituents elevated above background levels at the site.

- In some cases, data obtained from laboratory animal testing at exposure doses different from those expected at the site were used to determine toxicity. The relationship between dose and response is not always linear, and humans do not always exhibit the same responses as animals.

- Data used to determine toxicity are generally based on exposure to only the constituent of concern. In reality, exposures generally occur simultaneously to multiple constituents. The interactive effects of multiple constituents and the impact of these interactions on expected toxicity generally cannot be accurately assessed from existing data.

- Considerable effort has been directed at determining plume movement and placing monitor wells in locations that capture maximal contamination; however, variability in physical systems and models used to determine contaminant plume migration could still result in well placements that do not measure the highest contaminant concentrations or determine the fullest extent of plume impact.

- Variability can be introduced through sampling and analytical processes; however, data at UMTRA Project sites have been collected over many years and are subjected to rigorous quality assurance procedures. The use of 
multiple samples introduces high confidence in the reliability and validity of the data.

- The drinking water pathway is considered the major determinant of exposure in this assessment. Although other pathways for humans have been screened and determined not to contribute significantly to total exposure, the additivity of exposure from these pathways should be kept in mind. When a measurable contribution from other pathways could increase expected exposure significantly enough to alter the predicted toxicity, the alternate source contribution is noted in Section 6.0.

By presenting the reader with ranges of toxic effects, probable exposure distributions, summaries of available data on health effects and interactions, and outlines of potential limitations, this document provides a reasonable interpretation of potential health risks associated with ground water contamination at this site. This assessment presents both contamination and risk as accurately as possible, based on available data, and conveys areas of uncertainties.

\subsection{GROUND WATER CRITERIA}

In 1983, the EPA established health and environmental protection standards for the UMTRA Project (40 CFR Part 192); in 1987, the EPA proposed revised ground water standards (52 FR 36000 (1987)). The UMTRA Project is required to adhere to the 1987 proposed ground water standards until final standards are published. The proposed ground water standards consist of protection standards to evaluate disposal cell performance and cleanup standards for existing contamination at processing sites. These standards are summarized in Table 8.1 for contaminants that have a proposed maximum concentration limit (MCL). MCLs are not established for every contaminant; the proposed standard requires that contaminants without an $\mathrm{MCL}$ meet background levels. The proposed standards also allow for supplemental standards or alternate concentration limits $(A C L)$ where appropriate.

While these ground water protection and cleanup standards apply specifically to the UMTRA Project, the EPA has also published drinking water health advisory levels for both long-term and short-term exposures. These advisories also are shown in Table 8.1.

Concentrations of molybdenum, nitrate, selenium, vanadium, and uranium in the middle unit plume wells have consistently exceeded the EPA-proposed ground water MCL for UMTRA Project sites and/or the EPA health advisory levels. Exceedance of the MCL for lead has occurred only once, in well 581 . However, lead concentrations exceeded the lifetime health advisories for a $70-\mathrm{kg}$ adult. Boron, cadmium, chromium, lead, and mercury marginally exceeded the MCL and/or health advisories; however, the concentrations of these metals are not statistically above background levels. Thallium was not analyzed for in the ground water from background and plume wells. 
Table 8.1 Concentration limits of constituents in the Upper Cedar Mountain aquifer ground water

\begin{tabular}{|c|c|c|c|}
\hline & $\begin{array}{l}\text { Proposed } \\
\text { EPA MCL }\end{array}$ & $\begin{array}{l}\text { Health advisories } \\
10-\mathrm{kg} \text { child, 10-day }\end{array}$ & $\begin{array}{c}\text { Health advisories } \\
70-\mathrm{kg} \text { adult, lifetime }\end{array}$ \\
\hline Constituent & & $\mathrm{mg} / \mathrm{L}$ & \\
\hline \multicolumn{4}{|l|}{ Chemicals (inorganic) } \\
\hline Antimony ${ }^{a}$ & - & 0.015 & 0.003 \\
\hline Arsenic & 0.05 & - & - \\
\hline Barium & 1.0 & - & 2 \\
\hline Boron & - & $0.9^{\mathrm{b}}$ & $0.6^{b, c}$ \\
\hline Cadmium & $0.01^{b, c}$ & $0.04^{b}$ & $0.005^{b, c}$ \\
\hline Chromium & $0.05^{b, c}$ & 1.0 & $0.1^{\mathrm{b}}$ \\
\hline Copper & - & - & - \\
\hline Fluoride & - & - & - \\
\hline Lead & $0.05^{b}$ & - & $0.015^{b, d}$ \\
\hline Manganese & - & - & - \\
\hline Mercury & $0.002^{b}$ & - & $0.002^{b}$ \\
\hline Molybdenum & $0.1^{\mathrm{b}}$ & $0.08^{b}$ & $0.04^{b}$ \\
\hline Nickel $^{\mathrm{a}}$ & - & 1.0 & 0.1 \\
\hline Nitrate & $44^{b . e}$ & $44^{b, f}$ & - \\
\hline Selenium & $0.01^{b, c}$ & - & - \\
\hline Silver & 0.05 & 0.2 & 0.1 \\
\hline Strontium ${ }^{a}$ & - & 25.0 & 17 \\
\hline Sulfate & - & - & - \\
\hline Thallium ${ }^{9}$ & - & 0.007 & 0.0004 \\
\hline Vanadium & - & $0.08^{b}$ & $0.02^{b}$ \\
\hline Zinc & - & 6.0 & 2 \\
\hline \multicolumn{4}{|l|}{ Radionuclides } \\
\hline Radium-226/-228 & $5 \mathrm{pCi} / \mathrm{L}$ & & \\
\hline $\begin{array}{l}\text { Uranium } \\
\text { (U-234/-238) }\end{array}$ & $\begin{array}{c}30 \mathrm{pCi} / \mathrm{L}^{\mathrm{b}} \\
(0.044 \mathrm{mg} / \mathrm{L})\end{array}$ & $0.03 \mathrm{mg} / \mathrm{L}^{\mathrm{b}, \mathrm{h}}$ & $0.1 \mathrm{mg} / \mathrm{L}^{\mathrm{b}, \mathrm{h}}$ \\
\hline
\end{tabular}

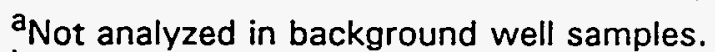

bexceeded in plume well samples.

${ }^{\mathrm{C}}$ Exceeded in background.

${ }^{\mathrm{C}}$ Action level.

Equals $10 \mathrm{mg} / \mathrm{L}$ nitrate as nitrogen.

Under review.

${ }^{\text {Not analyzed in background or plume well samples. }}$

hproposed value, under review; expected revision: 1995. 


\subsection{RISK MITIGATION MEASURES}

Serious health effects could result following short-term use of nitrate- and sulfate-contaminated ground water from the Upper Cedar Mountain and alluvium aquifers and of contaminated surface water in Brown's Wash at the Green River former uranium processing site. This section presents possible ways to restrict access to contaminated ground and surface water.

Institutional controls are defined in the proposed ground water standards for the UMTRA Project as mechanisms that can be used effectively to protect human health and the environment by controlling access to contaminated ground water (52 FR 36000 (1987)). Although the standards refer to institutional controls for long periods of time (up to 100 years during natural flushing), this concept can also be applied to short-term or interim restrictions of access to ground water. Because not all 24 UMTRA Project sites can be evaluated simultaneously, interim institutional controls are needed pending remedial action decisions or during implementation of remedial action for individual sites.

The city of Green River is west of the Green River in Emery County. The site is east of the river in Grand County. This creates a complex regulatory environment because the state of Utah, two counties, and the city of Green River may be involved in institutional controls at the site.

\section{State of Utah}

The state of Utah requires that new ground water wells be permitted by the state engineer's office. The permits ensure that wells are constructed properly and that the quantity of water withdrawn is acceptable. The state engineer's office also has the authority to require repair, capping, or plugging of any well to prevent pollution or contamination of ground water and to bring suits to prevent pollution of ground water.

A precedent has been set in the state of Utah restricting withdrawal of ground water. The state engineer's office has developed a Salt Lake Valley Ground Water Management Plan that uses the state engineer's authority to restrict new withdrawals of ground water to protect ground water quality. This has been applied at the Vitro site in Utah to restrict new withdrawals of ground water, preventing contaminated shallow aquifer water from being drawn down to the deeper aquifer.

If a surface source is contaminated, the Department of Health has the authority to publish a notice of the problem, post the area to state what restrictions are in place (e.g., no swimming, no fishing), and notify the sheriff so that the restrictions could be enforced (TAC, 1994b). 


\section{City of Green River}

Existing water wells in the city of Green River are hydrologically protected from the contaminant plume by the Green River. The city has a mandate to "protect public health, safety, and welfare" (TAC, 1994c). City planning and zoning personnel are authorized to interpret this mandate and make decisions case by case. Planning and zoning meetings are one forum for these personnel to make decisions addressing public health concerns. The DOE can use these meetings to communicate to city officials the status of the contaminant plume and to request city support in ensuring that contaminated ground water is not inadvertently consumed.

\section{Grand County}

The site and contaminated plume are in Grand County. The county has no specific provisions addressing control of contaminated ground water.

\section{Emery County}

Emery County has no jurisdiction over the use of ground water affected by the uranium processing site.

\subsection{RECOMMENDATIONS}

In general, the proposed ground water standards, consisting of MCLs or background concentrations, are sufficient to protect human health and the environment. However, in some cases, a risk assessment may identify sitespecific factors that suggest these standards may be either too restrictive or not restrictive enough. When standards are too restrictive, there may be no potential for exposure, and a less restrictive ACL may be sought. In other cases, the standards may not be sufficiently protective (e.g., if many contaminants are near the MCL with additive or synergistic adverse health effects).

At Green River, there is no permanent physical barrier to prevent access to contaminated ground water at the former uranium processing site. Therefore, ACLs could not be justified for constituents with MCLs. However, for constituents that exceed background and do not have MCLs, this risk assessment suggests that background levels are more restrictive than necessary. This includes contaminants that were screened out because their concentrations fell within nutritional levels (e.g., iron and nickel) and other contaminants, such as aluminum, ammonium, and vanadium, that were demonstrated to be at concentrations well below adverse health effect levels. ACLs should be sought for these contaminants. These recommendations apply to the Upper Cedar Mountain aquifer only, because background levels have been determined for this water-bearing unit. The recommendations do not apply to the Brown's Wash alluvium, since background levels could not be determined. 
The nitrate MCL of $44 \mathrm{mg} / \mathrm{L}(10 \mathrm{mg} / \mathrm{L}$ as nitrogen) may not sufficiently protect infants where sulfate concentrations are also high. Further study of this potential synergism is needed before remedial action decisions are made for this site.

The levels of nitrate present a serious health risk if contaminated ground water at this site is used. The levels within the contaminant plume in the Upper Cedar Mountain aquifer and the Brown's Wash alluvium substantially exceed levels at which fatal cases of methemoglobinemia in infants have been reported elsewhere. This situation requires that institutional controls be implemented as soon as possible, regardless of the remedial action strategy pursued.

Additional monitor wells in the vicinity of the former uranium processing site are needed to identify the magnitude of contamination in both the Upper Cedar Mountain and alluvial aquifers, determine the horizontal and vertical extent of the plume, and confirm vertical gradients in the Buckhorn Member of the Cedar Mountain Formation. Most of the former processing site wells on and adjacent to the tailings site were decommissioned during and after surface remediation; the available historical data represent the most recent complete data base, which was used in this risk assessment. The possible installation of such wells will be addressed in future UMTRA Project ground water investigation documents for the site.

The Brown's Wash alluvium background ground water chemistry requires more characterization. Existing data are not sufficient to identify mill-related potential contaminants and receptors, to precisely evaluate the Brown's Wash alluvium as a water resource, or to evaluate the potential risks associated with future uses of the alluvial ground water. Therefore, future beneficial uses of the Brown's Wash alluvial ground water (for example, for livestock watering or crop irrigation) should be evaluated, and the aquifer extent and yield should be established.

Ground water and surface water interactions in the vicinity of the site should be more clearly determined. Work plans may include installing shallow piezometers adjacent to Brown's Wash, a rain gauge, and a gauging station in Brown's Wash. Water level, rainfall, and stream flow measurements could be taken to determine whether ground water flows into the wash during and after rainfall events. Also, monitor wells could be installed near the Green River to evaluate regional ground water flow patterns.

Based on the results of the ecological risk assessment and consistent with the EPA's phased approach to conducting ecological assessments (EPA, 1989), additional surface water, sediment, and plant and/or animal tissue samples would provide a better picture of possible ecological impacts from site contamination. 


\subsection{LIST OF CONTRIBUTORS}

The following individuals contributed to the preparation of this report.

\begin{tabular}{ll}
\hline \multicolumn{1}{c}{ Name } & \multicolumn{1}{c}{ Contribution } \\
\hline B. Malczewska-Toth & Overall document responsibility; authorship \\
J. Lewis, L. Flowers & Senior technical review \\
K. Smith & Statistics \\
R. Papusch, A. Miller, & Hydrogeology \\
G. Ruskauff & \\
A. Groffman & Geochemistry \\
C. Burt & Ecological risk evaluation \\
M. Gawthrop-Cooper & Risk mitigation measures, institutional controls \\
J. Senger & Site management \\
E. Artiglia & Previous site management \\
E. Bond, T. Gagliano & Graphic design \\
C. Slosberg, L. Keith, L. Sanchez & Word processing \\
D. Thalley & Technical editing \\
\hline
\end{tabular}




\subsection{REFERENCES}

Aiyar, A. S., and A. Sreenivasan, 1961. Proceedings from the Society of Experimental Biology and Medicine, Vol. 107, pp. 914-916.

Alexander et al. (F. W. Alexander, B. E. Clayton, and H. T. Delves), 1974. O.J. Med., Vol. 53, pp. 89-111.

Allison et al. (J. D. Allison, D. S. Brown, and K. J. Novo-Gradac), 1991. MINTEQA2/PRODEFA2, A Geochemical Assessment Model for Environmental Systems, Version 3.0, User's Manual, EPA/600/3-91/021.

Baes et al. (C. F. Baes, R. D. Sharp, A. J. Sjoreen, and R. W. Shor), 1984. A Review and Analysis of Parameters for Assessing Transport of Environmentally Released Radionuclides through Agriculture, ORNL-5786, prepared for Oak Ridge National Laboratory, Health and Safety Research Division, Oak Ridge, Tennessee.

Ballou et al. (J. E. Ballou, R. A. Gies, A. C. Case, D. L. Haggard, R. L. Buschbom, and J. L. Ryan), 1986. "Deposition and Early Disposition of Inhaled Uranium-233 Uranyl Nitrate and Uranium-232 Uranyl Nitrate in the Rat," in Health Physics, No. 51, pp. 755-772.

Belehova, B. A., 1969. Scientific Transactions of the Irkutsk State Medical Institute, Vol. 96. pp. 20-23 (in Russian).

Berlin, M., and B. Rudell, 1986. "Uranium," in Handbook on the Toxicology of Metals, second edition, L. Friberg, G. F. Nordberg, and V. B. Vouk, eds., pp. 647-658, Elsevier Science Publishers, Amsterdam.

Bolyai et al. (J. Z. Bolyai, R. P. Smith, and C. T. Gray), 1972. "Ascorbic Acid and Chemically Induced Methemoglobinemias," in Toxicological Applied Pharmacology, Vol. 21, pp. 176-185.

Bopp et al. (B. A. Bopp, R. C. Sanders, and J. W. Kesterson), 1982. "Metabolic Fate of Selected Selenium Compounds in Laboratory Animals and Man," in Drug Metab. Rev., Vol. 13, pp. 271-318.

Brookins, D. G., 1988. Eh-pH Diagrams for Geochemistry, Springer-Verlag, Berlin, Germany.

Buchet et al. (J. P. Buchet, R. Lauwerys, and H. Roels), 1981. "Urinary Excretion of Inorganic Arsenic and its Metabolites After Repeated Ingestion of Sodium Metaarsenite by Volunteers", in International Archives of Occupational and Environmental Health, No. 48, pp. 111-118. 
Buchet et al. (J. P. Buchet, H. Roels, and R. Lauwerys), 1980. "Repeated Surveillance of Exposure to Cadmium, Manganese, and Arsenic in School-Age Children Living in Rural, Urban, and Nonferrous Smelter Areas in Belgium," in Environmental Research, No. 22, pp. 95-108.

Byerrum et al. (R. U. Byerrum, R. E. Eckardt, L. L. Hopkins), 1974. Vanadium, National Academy of Sciences, Washington, D.C.

Byrne, A. R., and L. Kosta, 1978. Sci. Total Environ., Vol. 10, pp. 17-30.

Calabrese, E. J., and R. W. Tuthill, 1977. "Elevated Blood Pressure and High Sodium Levels in the Public Drinking Water," in Archives of Environmental Health, September/October 1977, pp. 200-202.

Carson et al. (B. L. Carson, H. V. Ellis III, and J. L. McCann), 1986. Toxicology and Biological Monitoring of Metals in Humans, Lewis Publishers, Inc., New York, New York, pp. 226-230.

Casarett, L. J., and J. Doull, 1991. Toxicology: The Basic Science of Poisons, fourth edition, M. O. Amdur, J. Doull, and C. D. Klaassen, eds., Pergamon Press, New York, New York.

CDPHE (Colorado Department of Public Health and Environment), 1991. Basic Standards and Methodologies for Surface Water, 3.1.0., Water Quality Control Commission, Denver, Colorado.

Church, D. C., 1984. Livestock Feeds and Feeding, second edition, McGraw-Hill Publishing Co., New York, New York.

Cothern, C. R., and W. L. Lappenbusch, 1983. "Occurrence of Uranium in Drinking Water in the United States," in Health Physics, No. 45, pp. 89-99.

Crecelius, E. A., 1977. "Changes in the Chemical Speciation of Arsenic Following Ingestion by Man," in Environmental Health Perspective, No. 19, pp. 147-150.

Cummins, L. M., and E. T. Kimura, 1971. Toxicology and Applied Pharmacology, Vol. 20, pp. 89-96.

Curran et al. (G. L. Curran, D. L. Azarnoff, and R. E. Bolinger), 1959. Journal of Clinical Investigation, Vol. 38, pp. 1251-1261.

Deeb, B. S., and K. W. Sloan, 1975. "Nitrates, Nitrites, and Health," University of Illinois Colleges of Agriculture and Veterinary Medicine, Agricultural Experiment Station, Bulletin 750.

DHHS (U.S. Department of Health and Human Services), 1993. "Toxicological Profile for Arsenic," prepared by Life Systems, Inc., for Clement International Corporation for the U.S. Department of Health and Human Services. 
DHHS (U.S. Department of Health and Human Services), 1992. "Toxicological Profile for Manganese," U.S. Department of Health and Human Services, Atlanta, Georgia

DHHS (U.S. Department of Health and Human Services), 1989. "Toxicological Profile for Selenium," prepared by Clement Associates, for the U.S. Deaprtment of Health and Human Services.

Dimond et al. (E. G. Dimond, J. Caravaca, and A. Benchimol), 1963. "Vanadium: Excretion, Toxicity, Lipid Effect in Man," in American Journal of Clinical Nutrition, Vol. 12, pp. 49-53.

DOE (U.S. Department of Energy), 1994a. Programmatic Environmental Impact Statement for the Uranium Mill Tailings Remedial Action Ground Water Project, draft, DOE/EIS-0918, Rev. 3, prepared by the U.S. Department of Energy, UMTRA Project Office, Albuquerque Operations Office, Albuquerque, New Mexico.

DOE (U.S. Department of Energy), 1994b. Long-Term Surveillance Plan for the Green River, Utah, Disposal Site, DOE/AL/62350-89F, Rev. 1, August 1994, prepared by the U.S. Department of Energy, UMTRA Project Office, Albuquerque Operations Office, Albuquerque Operations Office, Albuquerque, New Mexico.

DOE (U.S. Department of Energy), 1994c. Mitigation and Monitoring Plan for Impacted Wetlands at the Gunnison UMTRA Project Site, Gunnison, Colorado, draft, DOE/AL/62350-85D, April 1994, prepared by the U.S. Department of Energy, UMTRA Project Office, Albuquerque Operations Office, Albuquerque, New Mexico.

DOE (U.S. Department of Energy), 1994d. Environmental Assessment of Remedial Action at the Maybell Uranium Mill Tailings Site Near Maybell, Colorado, DOE/EA-0347, April 1994, DOE UMTRA Project Office, Albuquerque Operations Office, Albuquerque, New Mexico.

DOE (U.S. Department of Energy), 1993a. 1993 Annual Environmental Monitoring Report for the Green River Site, UMTRA-DOE/CE-AC04-83AL18796, prepared by MKFerguson Company for the U.S. Department of Energy, UMTRA Project Office, Albuquerque Operations Office, Albuquerque, New Mexico.

DOE (U.S. Department of Energy), 1993b. UMTRA Water Sampling and Analysis Plan Green River, Utah, UMTRA-DOE/AL/62350-86D, December 1993, prepared by the U.S Department of Energy, UMTRA Project Office, Albuquerque, New Mexico.

DOE (U.S. Department of Energy), 1992. Vegetation Growth Patterns on Six RockCovered UMTRA Project Disposal Cells, UMTRA-DOE/AL-400677.0000, February 1992, prepared by the U.S. Department of Energy, UMTRA Project Office, Albuquerque Operations Office, Albuquerque, New Mexico. 
DOE (U.S. Department of Energy), 1991. Remedial Action Plan and Final Design for Stabilization of the Inactive Uranium Mill Tailings at Green River, Utah, UMTRADOE/AL-050510-GRNO, prepared by the U.S. Department of Energy, UMTRA Project Office, Albuquerque Operations Office, Albuquerque, New Mexico.

DOE (U.S. Department of Energy), 1988. Environmental Assessment of Remedial Action at the Green River Uranium Mill Tailings Site, Green River, Utah, DOE/EA-0343, prepared by the U. S. Department of Energy, UMTRA Project Office, Albuquerque Operations Office, Albuquerque, New Mexico.

Dreesen, D. R., and M. L. Marple, 1979. "Uptake of Trace Elements and Radionuclides From Uranium Mill Tailings by Four-Winged Saltbush (Atriplex canescens) and Alkali Sacaton (Sporobolus airoides)," symposium on Uranium Mill Tailings Management, Fort Collins, Colorado.

Dreesen et al. (D. R Dreesen, J. M. Williams, M. L Marple, E. S. Gladney, and D. R. Perrin), 1982. "Mobility and Bioavailability of Uranium Mill Tailings Contaminants," in Environmental Science and Technology, Vol. 16, No. 10, pp. 702-709.

Eisler, R., 1985a. "Cadmium Hazards to Fish, Wildlife, and Invertebrates: A Synoptic Review," U.S. Fish and Wildlife Service, Biological Report 85(1.2), Patuxent Wildlife Research Center, Laurel, Maryland.

Eisler, R. 1985b. "Selenium Hazards to Fish, Wildlife, and Invertebrates: A Synoptic Review," U.S. Fish and Wildlife Service, Biological Report 85(1.5), Patuxent Wildlife Research Center, Laurel, Maryland.

EPA (U.S. Environmental Protection Agency), 1994a. "Integrated Risk Information System (IRIS)," data base, Office of Research and Development, Washington, D.C.

EPA (U.S. Environmental Protection Agency), 1994b. "Health Effects Assessment Summary Tables (HEAST)," annual update, March 1994, 9200.6-303 (93-1), Office of Solid Waste and Emergency Response.

EPA (U.S. Environmental Protection Agency), 1992a. Drinking Water Criteria Document for Sulfate, final, Health and Environmental Criteria Division, Office of Science and Technology, U.S. Environmental Protection Agency.

EPA (U.S. Environmental Protection Agency), 1992b. "Developing a Work Scope for Ecological Assessments," in Eco Update, intermittent bulletin, Vol. 1, No. 4, U.S. Environmental Protection Agency, Office of Emergency and Remedial Response, Hazardous Site Evaluation Division, Washington, D.C.

EPA (U.S. Environmental Protection Agency), 1991. "304(a) Criteria and Related Information for Toxic Pollutants," EPA Region IV, Water Management Division. 
EPA (U.S. Environmental Protection Agency), 1989a. Risk Assessment Guidance for Superfund, Vol. I, Human Health Evaluation Manual, EPA/540/1-89/002, Office of Emergency and Remedial Response, Washington, D.C.

EPA (U.S. Environmental Protection Agency), 1989b. Risk Assessment Guidance for Superfund, Vol. II, Environmental Evaluation Manual, EPA/540/1-89/001, Office of Emergency and Remedial Response, Washington, D.C.

EPA (U.S. Environmental Protection Agency), 1986. "Quality Criteria for Water, 1986," Environmental Protection Agency, Office of Water, Regulations, and Standards, Washington, D.C.

EPA (U.S. Environmental Protection Agency), 1984. Health Assessment Document: Inorganic Arsenic, U.S. Environmental Protection Agency, Washington, D.C.

EPA (U.S. Environmental Protection Agency), 1980. Ambient Water Quality Criteria for Selenium, EPA 440/5-80-070, NTIS PB 81-117814, prepared by the Office of Health and Environmental Assessment, Environmental Criteria and Assessment Office, Cincinnati, Ohio, for the Office of Water Quality Planning Standards, Washington, D.C.

EPA (U.S. Environmental Protection Agency), 1977. Scientific and Technical Assessment Report on Vanadium, EPA-600-6-77-002, U.S. Environmental Protection Agency, Washington, D.C.

EPA (U.S. Environmental Protection Agency), 1972. "Water Quality Criteria," National Academy of Sciences and National Academy of Engineering, Washington, D.C.

FBDU (Ford, Bacon \& Davis Utah Inc.), 1981. A Summary of the Engineering Assessment of Inactive Uranium Mill Tailings, Green River Site, Green River, Utah, DOE/UMT-0114S, FBDU 360-14S, UC 70, prepared by Ford, Bacon \& Davis Utah, Salt Lake City, Utah, for the U.S. Department of Energy, UMTRA Project Office, Albuquerque Operations Office, Albuquerque, New Mexico.

Ferm, V. H., 1971. "The Teratogenic Profile of Sodium Arsenate in the Golden Hamster," in Archives of Environmental Health, No. 22, pp. 557-560.

Fisenne et al. (I. M. Fisenne, P. M. Perry, and N. H. Harley, 1988. "Uranium in Humans," in Radiation Protection Dosimetry, No. 24, pp. 127-131.

Freis, E. D., 1976. "Salt, Volume and the Prevention of Hypertension," in Circulation, Vol. 53, No. 4, pp. 589-595.

Friberg et al. (L. Friberg, G. F. Nordberg, and V. B. Vouk), 1986. Handbook on the Toxicology of Metals, Volume II: Specific Metals, second edition, Elsevier, New York, New York. 
Gosselin et al. (R. E. Gosselin, H. C. Hodge, and R. P. Smith), 1976. Clinical Toxicology of Commercial Products, fourth edition, Williams and Wilkins, Baltimore, Maryland.

Goyer, Robert A., 1991. "Toxic Effects of Metals," in Casarett and Doull's Toxicology: The Basic Science of Poisons, pp. 623-680, fourth edition, M. O. Amdur, J. Doull, and C. D. Klaassen, eds., Pergamon Press, New York, New York.

Hadjimarkos, D. M., 1968. Adv. Oral Biol., Vol 3, pp. 253-292.

Hadjimarkos, D. M., 1966. Nature, Vol. 209, p. 1137.

Harris et al., 1984. (W. R. Harris, S. B. Friedman, and D. Silberman), 1984. Journal of Inorganic Biochemistry, Vol. 20, pp. 157-169.

Hobbs, R. J., and B. Streit, 1986. "Heavy Metal Concentrations in Plants Growing on a Copper Mine Spoil in the Grand Canyon, Arizona," in The American Midland Naturalist, Vol. 115, No. 2, pp 277-281.

Hood, R. D., 1972. "Effects of Sodium Arsenite on Fetal Development," in Bulletin of Environmental Contamination and Toxicology, No. 7, p. 216.

Ibrahim, S. A., and F. W. Whicker, 1988. "Comparative Uptake of $U$ and Th by Native Plants at a U Production Site," in Health Physics, Vol. 54, No. 4, pp. 413-419.

ICRP (International Commission on Radiological Protection), 1960. ICRP Pub/., 2.

Ishinishi et al. (N. Ishinishi, K. Tsuchiya, M. Vahter, and B. A. Fowler), 1986. "Arsenic," in Handbook on the Toxicology of Metals, Volume II: Specific Metals, second edition, Elsevier Press Science Publishers B.V., Amsterdam, the Netherlands.

Israeli, M., and C. B. Nelson, 1992. "Distribution and Expected Time of Residence for U.S. Households," in Risk Analysis, Vol. 13, No. 1, pp. 65-72.

JEG (Jacobs Engineering Group, Inc.), n.d. Albuquerque Operations Manual, standard operating procedures, prepared by Jacobs Engineering Group, Albuquerque, New Mexico, for the U.S. Department of Energy, UMTRA Project Office, Albuquerque Operations Office, Albuquerque, New Mexico.

Kabata-Pendias, A., and H. Pendias, 1992. Trace Elements in Soils and Plants, second edition, CRC Press, Boca Raton, Florida.

Kamm et al. (L. Kamm, G. G. McKeown, and D. M. Smith), 1965. "New Colorimetric Method for the Determination of the Nitrate and Nitrite Content of Baby Foods," in J. Assoc. Offic. Agr. Chemists, Vol. 48, p. 892.

Knepp, G. L., and G. F. Arkin, 1973. "Ammonia Toxicity Levels and Nitrate Tolerance of Channel Catfish," in The Progressive Fish Culturist, Vol. 35, p. 221. 
Kondakis, et al. (X. G., N. Makris, M. Leotsinidis, M. Prinou, and T. Papapetropoulos), 1989. "Possible Health Effects of High Manganese Concentration in Drinking Water," in Archives of Environmental Health, 1989, Vol. 44, No. 3, pp. $175-178$.

Lagerkvist et al. (B. Lagerkvist, G. F. Nordberg, and V. Vouk), 1986. "Vanadium," in Handbook on the Toxicology of Metals, second edition, L. Friberg, G. F. Nordberg, and V. Vouk, eds., Elsevier Science Publishers, New York, New York.

Lapham et al. (S. C. Lapham, J. B. Millard, J. M. Samet, 1989. "Health Implications of Radionuclide Levels in Cattle Raised Near U Mining and Milling Facilities in Ambrosia Lake, New Mexico," in Health Physics, Vol. 56, No. 3, pp. 327-340.

Leach et al. (L. J. Leach, R. M. Gelein, B. J. Panner, C. L. Ylie, and C. C. Cox), 1984. The Acute Toxicity of the Hydrolysis Products of Uranium Hexafluoride (UF6) When Inhaled by the Rat and Guinea Pig, final report, ISS K/SUB-81-9039-3. National Technical Information Service, Springfield, Virginia.

Lee, D. H. K., 1970. "Nitrates, Nitrites, and Methemoglobinemia," in Environmental Research, Vol. 3, pp. 484-511.

Lemly, A. D., and G. J. Smith, 1987. "Aquatic Cycling of Selenium: Implications for Fish and Wildlife," Fish and Wildlife Service Leaflet 12, U.S. Fish and Wildlife Service, Washington, D.C.

Lindgren et al. (A. Lindgren, M. Vahter, and L. Dencker), 1982. "Autoradiographic Studies on the Distribution of Arsenic in Mice and Hamsters Administered ${ }^{74}$ As-arsenite or -arsenate," in Acta Pharmacology and Toxicology, No. 51, pp. 253-265.

Long, E. R., and L. G. Morgan, 1990. "The Potential for Biological Effects of Sedimentsorbed Contaminants Tested in the National Status and Trends Program," National Oceanic and Atmospheric Administration, Technical Memorandum NOS OMA 52, Seattle, Washington.

Lönnerdal et al. (B. Lönnerdal, C. L. Keen, J. G. Bell, and B. Sandstrom), 1987. "Manganese Uptake and Retention," in Nutritional Bioavailability of Manganese, C. Kies, ed., American Chemical Society, symposium series 354, pp. 9-20, American Chemical Society, Washington, D.C.

Marafante, E., and M. Vahter, 1987. "Solubility, Retentions and Metabolism of Intratracheally and Orally Administered Inorganic Arsenic Compounds in Hamsters," in Environmental Research, No. 42, pp. 72-82.

Marcus, W. L., and A. S. Rispin, 1988. "Threshold Carcinogenicity Using Arsenic as an Example," in Advances in Environmental Toxicology, Volume XV, Risk Assessment and Risk Management of Industrial and Environmental Chemicals, C. R. Cothern, M. A. Mehlman, and W. L. Marcus, eds., Princeton Scientific Publishing Co., New Jersey, pp. 133-159. 
Maynard, E. A., and H. C. Hodge, 1949. "Study of Toxicity of Various Uranium Compounds When Fed to Experimental Animals," in Pharmacology and Toxicology of Uranium Compounds, National Nuclear Energy Services, Div. VI, Vol. 1, pp. 309-376, C. Voegtlin and H. C. Hodge, eds., McGraw Hill, New York, New York.

Medinsky et al. (M. A. Medinsky, R. G. Cuddihy, and R. O. McClellan), 1981. J. Toxicol. Environ. Health, Vol. 8, pp. 917-928.

Mena et al. (1. Mena, K. Horiuchi, K. Burke, and G. C. Cotzias), 1969. "Chronic Manganese Poisoning. Individual Susceptibility and Absorption of Iron," in Neurology, No. 19, pp. 1000-1006.

Meneely, G. R., and H. D. Battarbee, 1976. "Sodium and Potassium," in Nutrition Reviews, No. 8, pp. 225-235.

Merritt, R. C., 1971. The Extractive Metallurgy of Uranium, Colorado School of Mines Research Institute, Golden, Colorado, 1971.

Millar et al. (K. R. Millar, M. A. Gardiner, and A. D. Sheppard), 1973. New Zealand Journal of Agricultural Research, Vol. 16, pp. 115-127.

Morrison et al. (G. M. P. Morrison, G. E. Batley, and T. M. Florence), 1989. "Metal Speciation and Toxicity," in Chem. Br., No. 25, p. 791.

NAS (National Academy of Sciences), 1972. "Accumulation of Nitrate," Committee on Nitrate Accumulation, Agricultural Board, Division of Biology and Agriculture, National Research Council, Washington, D.C.

National Research Council, 1980. Drinking Water and Health, Volume 3, Safe Drinking Water Committee.

National Research Council, 1973. Medical and Biological Effects of Environmental Pollutants: Manganese, Committee on Biologic Effects of Atmospheric Pollutants, Division of Medical Sciences.

National Research Council, 1971. "Nutrient Requirements of Dairy Cattle," Committee on Animal Nutrition, fourth edition, the National Academy of Sciences, Washington, D.C.

NCRP (National Council on Radiation Protection and Measurements), 1984. "Exposures from the Uranium Series with Emphasis on Radon and its Daughter," NCRP Report No. 77, Bethesda, Maryland.

NOAA (National Oceanic and Atmospheric Administration), 1980. "Climatography of the United States No. 20, Green River, Utah," National Climatic Center, Asheville, North Carolina. 
NRC (U.S. Nuclear Regulatory Commission), 1990. Final Technical Evaluation Report for the Proposed Remedial Action at the Green River Tailings Site, Green River, Utah, prepared by the U.S. Nuclear Regulatory Commission, dated March 22, 1990, available in the UMTRA Project Document Control Center, UMTRA Project Office, Albuquerque Operations Office, Albuquerque, New Mexico.

Ohlendorf, H. M., 1989. "Bioaccumulation and Effects of Selenium in Wildlife," Soil Science Society of America, special publication number 23, Madison, Wisconsin.

Palisade Corporation, 1992. @RISK, Risk Analysis and Simulation Add-In for Lotus 1-2-3, Version 2.01, Newfield, New York.

Parkhurst et al. (D. L. Parkhurst, D. C. Thorstenson, and L. N. Plummer), 1980. PHREEQE-A Computer Program For Geochemical Calculations, U.S. Geological Survey, Water-Resources Investigation 80-96.

Pennington, Jean A., and John W. Jones, 1987. "Molybdenum, Nickel, Cobalt, Vanadium, and Strontium in Total Diets," in Journal of the American Dietetic Association, Vol. 87, No. 12, December 1987. American Dietetic Association, Division of Nutrition and Division of Contaminants Chemistry, Center for Food Safety and Applied Nutrition, Food and Drug Administration, Washington, D.C.

Perry et al. (H. M. Perry, Jr., S. Teitlebaum, and P. L. Schwartz), 1955. Federal Proceedings, Vol. 14, pp. 113-114.

Persaud et al. (D. Persaud, R. Jaagumagi, and A. Hayton), 1990. "The Provincial Sediment Quality Guidelines," Ontario Ministry of the Environment, Water Resources Branch, Toronto, Ontario.

Pershagen, G., and M. Vahter, 1979. Arsenic, Swedish Environmental Protection Board, Stockholm, Sweden.

Plummer et al. (L. N. Plummer, B. F. Jones, and A. H. Truesdell), 1976. WATEQF: A FORTRAN IV Version of WATEQ, a Computer Program for Calculating Chemical Equilibrium of Natural Waters, U.S. Geological Survey, Water-Resources Investigation-76-13.

PNL (Pacific Northwest Laboratory), 1989. "Sorption Distribution Coefficient Data," Multimedia Environmental Pollutant Assessment, Pacific Northwest Laboratory, Richland, Washington.

Poston et al. (T. M. Poston, R. W. Hanf, and M. A. Simmons), 1984. "Toxicity of Uranium to Daphnia magna," in Water Air and Soil Pollution, Vol. 22, pp. 289-298.

Prister, B. S., 1969. GKIAE Report by Atomizdat, Moscow (Canadian translation AEC/TR/7178 (1970), and USCEAR Rep. A/AC.82/G/L 1298). 
Proescher et al. (F. Proescher, H. A. Seil, and A. W. Stillians), 1917. Am. J. Syph., Vol. 1, pp. 347-405.

Rai, D., and J. M. Zachara, 1984. Chemical Attenuation Rates, Coefficients, and Constants in Leachate Migration, Volume 1: A Critical Review, EPRI, EA-3356, Volume 1, Research Project 2188-1.

Robinson et al. (M. F. Robinson, J. M. McKenzie, C. Thomson, and A. L. Van Rijn), 1973. Br. J. Nutr., Vol. 30, pp. 195-205.

Roseberry, A. M., and D. E. Burmaster, 1992. "Lognormal Distributions for Water Intake by Children and Adults," in Risk Analysis, Vol. 12, No. 1, pp. 99-104.

Rosenfeld, I., and O. A. Beath, 1964. Selenium, Geobotany, Biochemistry, Toxicity, and Nutrition, Academic Press, New York.

Rosoff, B., and H. Spencer, 1964. Nature (London), Vol. 202, pp. 410-411.

Saric, M., 1986. "Manganese," Handbook on the Toxicology of Metals, Vol. II, pp. 354386, L. Friberg, G. F. Nordberg, V. B. Vouk, eds., Elsevier, New York.

Schroeder et al. (H. A. Schroeder, J. J. Balassa, and I. H. Tipton), 1963. Journal of Chronic Diseases, Vol. 16, pp. 1047-1071.

Shannon, R. L., and D. S. Strayer, 1989. "Arsenic-Induced Skin Toxicity," in Human Toxicology, No. 8, pp. 99-104.

Smith, G. E., 1966. "Causes of Nitrate Accumulation in Plants and Water Supplies," paper to 18th Annual Midwest Fertilizer Conference, Chicago, Illinois.

Snyder, F., and W. E. Cornatzer, 1958. Nature, Vol. 182, pp. 462.

Somerville, J., and B. Davies, 1962. American Health Journal, Vol. 54, pp. 54-56.

Stevens et al. (W. F. Stevens, W. Bruenger, D. R. Atherton, J. M. Smith, and G. N. Taylor), 1980. "The Distribution and Retention of Hexavalent ${ }^{233} U$ in the Beagle," in Radiation Research, No. 83, pp. 109-126.

Sullivan et al. (M. F. Sullivan, P. S. Ruemmler, J. L. Ryan, and R. L. Bushhom), 1986. "Influence of Oxidizing or Reducing Agents on Gastrointestinal Absorption of $U$, Pu, Am, Cm, and Pm by Rats," in Health Physics, No. 50, pp. 223-232.

Summerskill, W. H. J., and E. Wolpert, 1970. "Ammonia Metabolism in the Gut," in American Journal of Clinical Nutrition, Vol. 23, pp. 633-639. 
TAC (Technical Assistance Contractor), 1994a. "Information on Deep Well Located Near Airport," compiled by the Technical Assistance Contractor, Jacobs Engineering Group inc., for the U.S. Department of Energy, UPDCC File Location No. 10.19.2.2.2, UMTRA Project Office, Albuquerque Operations Office, Albuquerque, New Mexico.

TAC (Technical Assistance Contractor), 1994b. Personal communication with State of Utah sanitarian, August 23, 1994, compiled by M. Gawthrop-Cooper of the Technical Assistance Contractor, Jacobs Engineering Group Inc., for the U.S. Department of Energy, UPDCC File Location No. 10.19.7, UMTRA Project Office, Albuquerque Operations Office, Albuquerque, New Mexico.

TAC (Technical Assistance Contractor), 1994c. Personal communication with Zoning and Planning officer, City of Green River, August 23, 1994, compiled by M.

Gawthrop-Cooper of the Technical Assistance Contractor, Jacobs Engineering Group Inc., for the U.S. Department of Energy, UPDCC File Location No. 10.19.7, UMTRA Project Office, Albuquerque Operations Office, Albuquerque, New Mexico.

TAC (Technical Assistance Contractor), 1993a. "Green River Site Aquifer Yield Calculations," GRN-01-11-93-14-09-00, November 8, 1993, prepared by the Technical Assistance Contractor, Jacobs Engineering Group Inc., for the U.S. Department of Energy, UPDCC File Location Nos. 10.19.2.7, 10.19.2.5.1, UMTRA Project Office, Albuquerque Operations Office, Albuquerque, New Mexico.

TAC (Technical Assistance Contractor), 1993b. "Survey of Land and Water Use," conducted by the Technical Assistance Contractor, Jacobs Engineering Group Inc., for the U.S. Department of Energy, UPDCC File Location No. 10.16.3, UMTRA Project Office, Albuquerque Operations Office, Albuquerque, New Mexico.

TAC (Technical Assistance Contractor), 1993c. "Unpublished Field Notes, Green River, Utah, Uranium Mill Tailings Site," unpublished report prepared by the TAC, Albuquerque, New Mexico, for the U.S. Department of Energy, UMTRA Project Office, Albuquerque Operations Office, Albuquerque, New Mexico.

TAC (Technical Assistance Contractor), 1991. "Unpublished Field Notes, Green River, Utah, Uranium Mill Tailings Site," unpublished report prepared by the TAC, Albuquerque, New Mexico, for the U.S. Department of Energy, UMTRA Project Office, Albuquerque Operations Office, Albuquerque, New Mexico.

Tank, G., and C. A. Storvick, 1960. Journal of Dental Research, Vol. 39, pp. 473-488.

Tipton et al. (I. H. Tipton, P. L. Stewart, and J. Dickson), 1969. Health Physics, Vol. 9, pp. 103-145. 
Tracy et al. (B. L. Tracy, J. M. Quinn, J. Lahey, A. P. Gilman, K. Mancuso, A. P. Yagdinas, and D. C. Villeneuve), 1992. "Absorption and Retention of Uranium from Drinking Water by Rats and Rabbits," in Health Physics, Vol. 62, pp. 65-73.

Tracy et al. (B. L. Tracy, F. A. Prantl, and J. M. Quinn,) 1983. "Transfer of ${ }^{226} \mathrm{Ra},{ }^{210} \mathrm{~Pb}$, and Uranium from Soil to Garden Produce: Assessment of Risk," in Health Physics, Vol. 44, p. 469.

Trama, F. B., 1954. "The Acute Toxicity of Some Common Salts of Sodium, Potassium and Calcium to the Common Bluegill (Lepomis macrochirus Rafinesque)," Proceedings of the National Academy of Sciences, Vol. 106, p. 185.

Tseng, W. P., 1977. "Effects and Dose-Response Relationship of Skin Cancer and Blackfoot Disease with Arsenic," in Environmental Health Perspectives, No. 19, pp. 109-119.

UDEQ (Utah Department of Environmental Quality), 1992. "Standards of Quality for Waters of the State," Utah Department of Environmental Quality, Division of Water Quality, Salt Lake City, Utah.

USGS (United States Geological Survey), 1982. Regional Hydrology of the Green RiverMoab Area, Northwestern Paradox Basin, Utah, Open-File Report 82-107, prepared in cooperation with the U.S. Department of Energy.

Van Zinderen Bakker and J. F. Jaworski, 1980. Effects of Vanadium in the Canadian Environment, Ottawa, Canada: National Research Council Canada, Associate Committee Scientific Criteria for Environmental Quality.

Venugopal, B., and T. D. Luckey, 1978. "Chemical Toxicity of Metals and Metalloids," in Metal Toxicity in Mammals, Plenum Press, New York, New York.

Webb, J. L., 1966. Enzymes and Metabolic Inhibitors, Academic Press, New York, New York.

Weigel, F., 1983. "Uranium and Uranium Compounds," in Kirk-Othmer Encyclopedia of Chemical Technology, Vol. 23, third edition, pp. 502-547, M. Grayson, ed., John Wiley and Sons, New York, New York.

Westin, D. T., 1974. "Nitrate and Nitrite Toxicity to Salmoid Fishes," in The Progressive Fish Culturist, Vol. 36, p. 86.

WHO (World Health Organization), 1988. Vanadium, Environmental Health Criteria 81, published under the joint sponsorship of the United Nations Environment Programme, the International Labour Organisation, and the World Health Organization, Geneva, Switzerland. 
WHO (World Health Organization), 1981. Arsenic, Environmental Health Criteria 18, published under the joint sponsorship of the United Nations Environment Programme, the International Labour Organisation, and the World Health Organization, Geneva, Switzerland.

Wrenn et al. (M. E. Wrenn, P. W. Durbin, B. Howard, J. Lipsztein, J. Rundo, E. T. Still, and D. L. Willis), 1985. "Metabolism of Ingested $U$ and $R a, "$ in Health Physics, No. 48, pp. $601-633$.

Yakawa, M., and M. Suzuki-Yasumoto, 1980. Arch. Environ. Health, Vol. 35, pp. 36-44.

Yang et al. (G. Yang, R. Zhou, and S. Yin), 1989a. "Studies of Safe Maximal Daily Dietary Selenium Intake in a Seleniferous Area in China," I, in J. Trace Elem.

Electrolytes Health Dis., Vol. 3(2), pp. 77-87.

Yang et al. (G. S. Yang, R. Zhou, and S. Yin), 1989b. "Studies of Safe Maximal Daily Dietary Selenium Intake in a Seleniferous Area in China," II, Relation Between Selenium Intake and the Manifestation of Clinical Signs and Certain Biochemical Alterations in Blood and Urine," in J. Trace Elem. Electrolytes Health Dis., Vol. $3(2)$, pp. $123-130$.

\section{CODE OF FEDERAL REGULATIONS}

10 CFR Part 40, Domestic Licensing of Source Materials, U.S. Nuclear Regulatory Commission (1994).

40 CFR Part 192, Health and Environmental Protection Standards for Uranium and Thorium Mill Tailings, U.S. Environmental Protection Agency (1994).

\section{FEDERAL REGISTER}

52 FR 36000, "Standards for Remedial Actions at Inactive Uranium Processing Sites; Proposed Rule," September 24, 1987.

\section{UNITED STATES CODE}

42 USC $\$ 6901$ et seq., Resource Conservation and Recovery Act, October 21, 1976.

42 USC $\$ 7901$ et seq., Uranium Mill Tailings Radiation Control Act, November 8, 1978. 